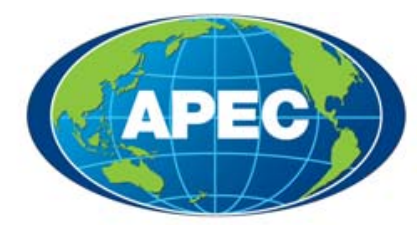

Asia-Pacific

Economic Cooperation

\title{
Survey of Biomass Resource Assessments and Assessment Capabilities in APEC Economies
}

Energy Working Group

November 2008 
Report prepared for the APEC Energy Working Group under EWG 01/2007A by:

Anelia Milbrandt

National Renewable Energy Laboratory (NREL)

Golden, Colorado, USA

Web site: www.nrel.gov

Dr. Ralph P. Overend

NREL Research Fellow (Retired)

Ottawa, Ontario, Canada

APEC\# 208-RE-01.9 


\section{Acknowledgments}

The authors would like to acknowledge and thank the project overseer Mr. Jeffrey Skeer (Department of Energy, USA and chair of APEC Biofuels Task Force) for his support and guidance throughout this project.

The authors also greatly appreciate the time and valuable contributions of the following individuals:

Ms. Naomi Ashurst and Ms. Marie Taylor, Department of Industry, Tourism and Resources, Australia Ms. Siti Hafsah, Office of the Minister of Energy, Brunei Darussalam

Mr. Mark Stumborg, Agriculture and Agri-Food, Canada

Ms. Corissa Petro, National Energy Commission, Chile

Mr. Song Yanqin, National Development and Reform Commission, China

Mr. Denis Y.C. Leung, Department of Mechanical Engineering, University of Hong

Kong, China

Mr. Steve Choi, Dynamic Progress Ltd., Hong Kong, China

Mr. Takao Ikeda, Institute for Energy Economics, Japan

Ms. Nunuk Wiryawan, Department of Energy and Mineral Resources, Indonesia

Dr. Soon-Chul Park, Korea Institute of Energy Research

Mr. Adrián Ghilardi, Bioenergy Laboratory, National Autonomous University of Mexico

Mr. Peter Hall, Scion Research, New Zealand

Mr. Aleksey Ablaev, Russian Biofuels Association

Dr. Hom-Ti (Thomas) Lee, Industrial Technology Research Institute, Chinese Taipei

Ms. Judy Oberg, National Renewable Energy Laboratory (NREL), USA

Mr. Jason Coughlin, National Renewable Energy Laboratory (NREL), USA

Ms. Kristen Durham, 2007 summer intern at NREL from University of California -

Berkeley, USA 


\section{Table of Content}

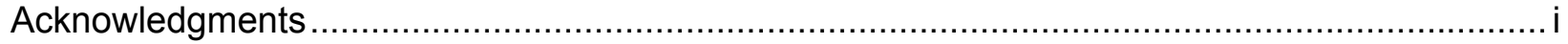

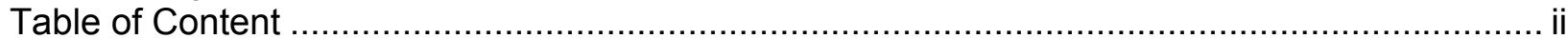

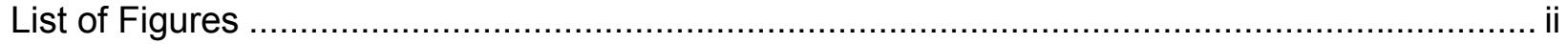

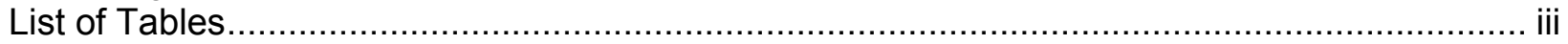

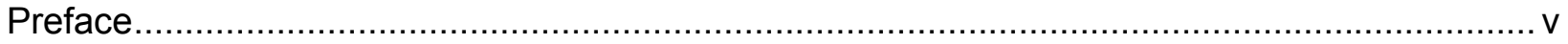

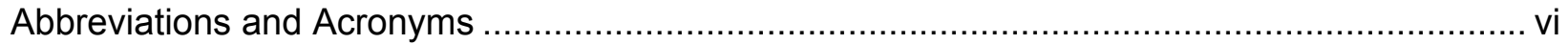

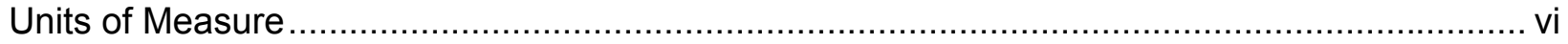

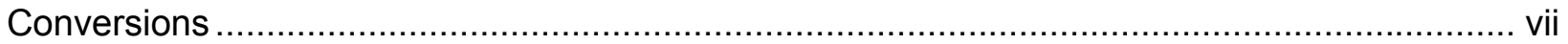

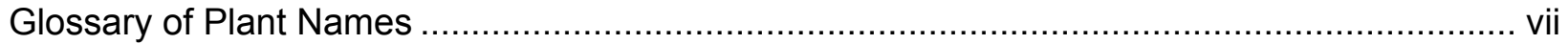

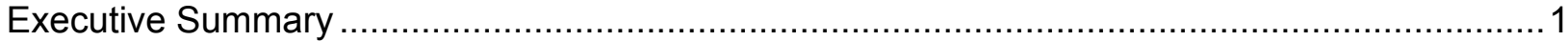

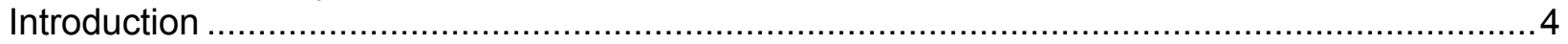

Biomass Resource Assessment Products and Assessment Methodologies ..............................

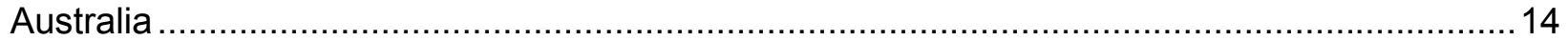

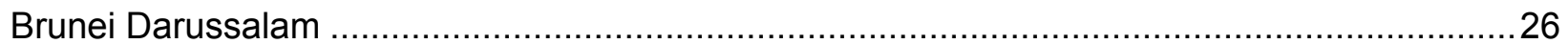

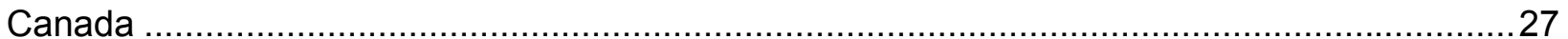

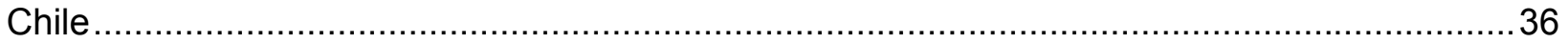

China

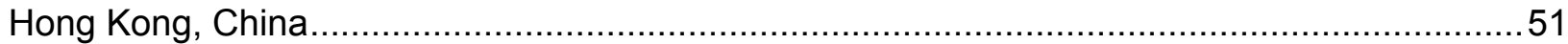

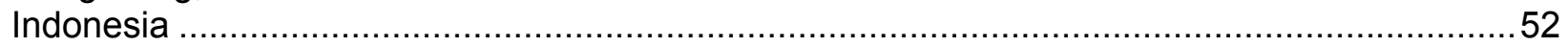

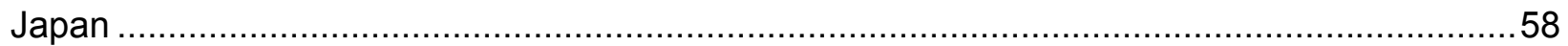

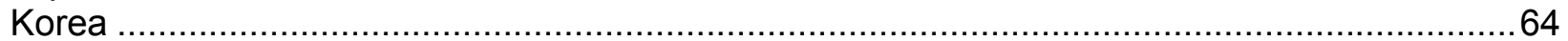

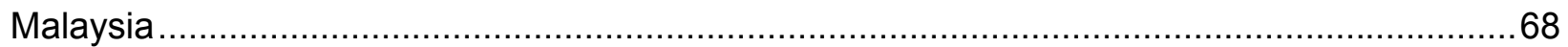

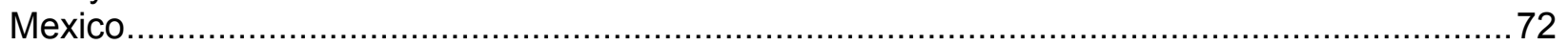

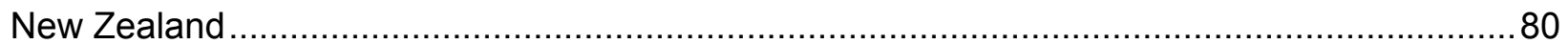

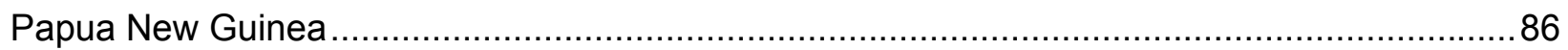

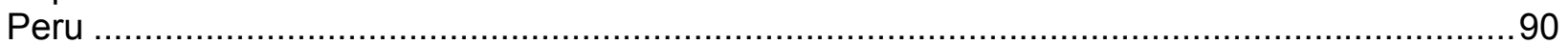

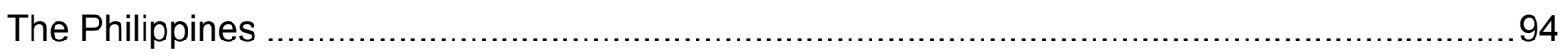

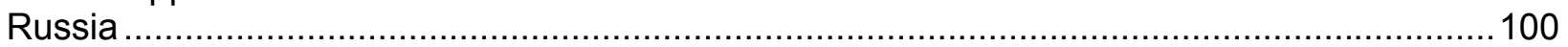

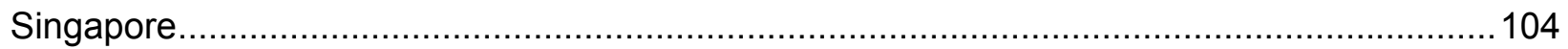

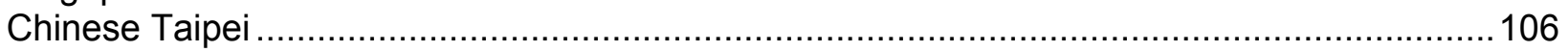

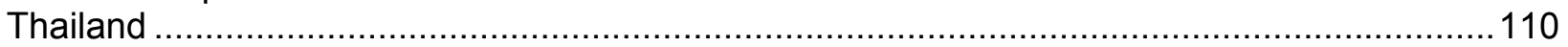

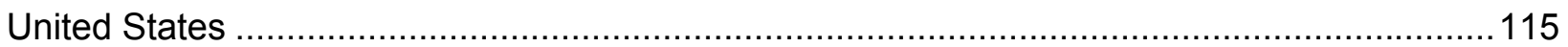

Viet Nam

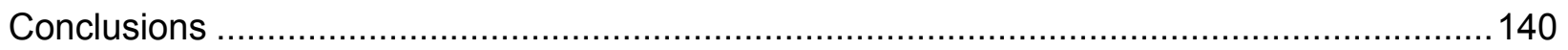

\section{List of Figures}

Figure 1. Average Ethanol Production per Hectare of Farmland Yield by Crop..........................6

Figure 2. Average Biodiesel Production per Hectare of Farmland Yield by Crop ........................ 7

Figure 3. Agricultural Fields Around the World .................................................................11

Figure 4. Conceptual Model of GIS ............................................................................... 11

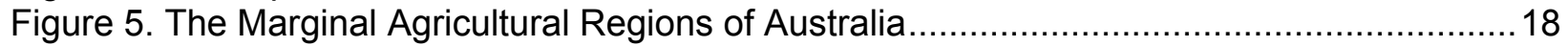

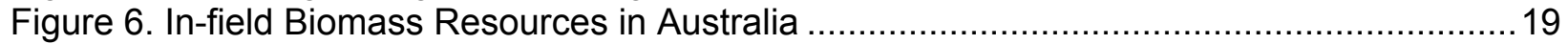

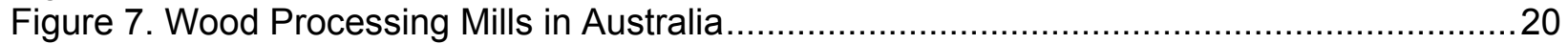

Figure 8. Potential Tree Crops for Salinity Hazard Reduction in Australia ...............................20

Figure 9. Softwood Mill Residues in Canada ............................................................... 31

Figure 10. Forest Inventory Process in Canada ……....................................................... 
Figure 11. Areas of Potential Surplus Wheat Straw in Western Canada ..................................34

Figure 12. Distribution of Primary Mill Residues in the Region of Bio-Bio, Chile ......................37

Figure 13. Plantation Forests in the Region of Bio-Bio, Chile .......................................... 38

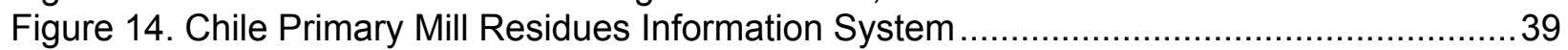

Figure 15. Rice Straw Production in 2004, Gg per $1 \mathrm{~km}$ pixel. ......................................... 43

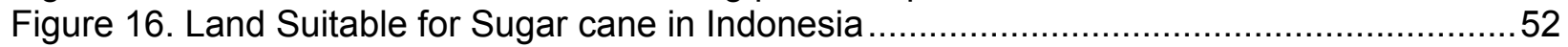

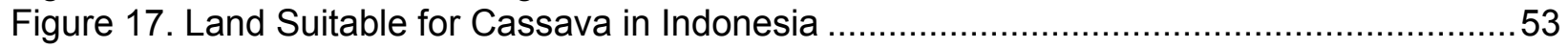

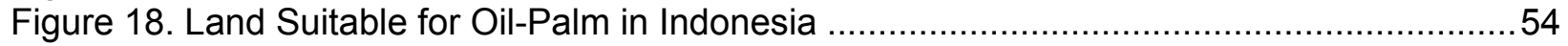

Figure 19. Land Suitable for Jatropha Curcas in Indonesia ............................................5

Figure 20. Areas Suitable for Winter Canola in Korea ..................................................6

Figure 21. Suitable Areas for Biodiesel Feedstock Production in Mexico................................75

Figure 22. Energy Potential of Crop Residues in Mexico ...................................................76

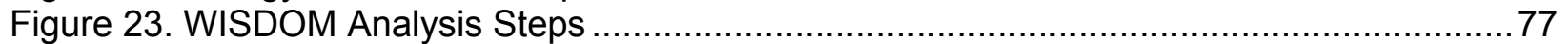

Figure 24. Primary Mill Residues in New Zealand by Region, 2005 .................................. 83

Figure 25. Estimating Area of Deforestation in Papua New Guinea .................................... 88

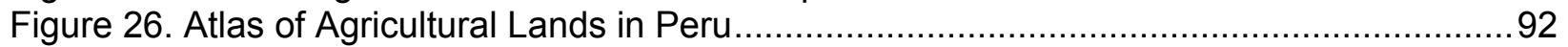

Figure 27. Annual Rice Hull Production by Province in the Philippines, 1999 .........................96

Figure 28. Maps of Crops and Forest Resources in Russia .............................................102

Figure 29. Map of Timber Volume of National Forest in Chinese Taipei ...............................108

Figure 30. Crops and Crop Residues in Roi-Et Province, Thailand ....................................112

Figure 31. Potential Forest and Agricultural Resources in the United States ........................118

Figure 32. Technically Available Biomass Resources in the United States ..........................119

Figure 33. Biomass Resources Available in the United States by County.............................120

Figure 34. Potential Switchgrass Production on CRP Lands ........................................... 122

Figure 35. United States Bioenergy Assessment Tool .............................................. 126

Figure 36. Forest Cover - Viet Nam ................................................................... 138

\section{List of Tables}

Table 1. Upper Limits to Ethanol Production Using Current Domestic Feedstock Supply

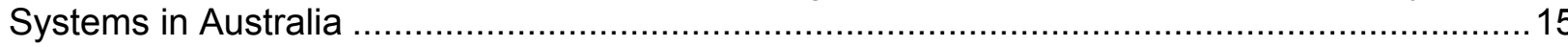

Table 2. Upper Limits to Biodiesel Production Using Current Domestic Feedstock Supply

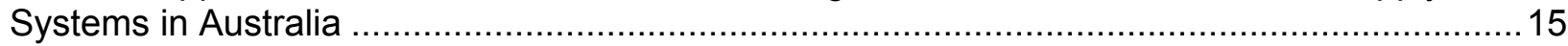

Table 3. Upper Limits to Biofuels Production Using Second-generation Feedstock Resources in

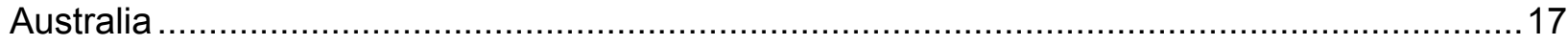

Table 4. Marginal Lands for the Production of Exotic Biofuel Crops in Australia......................18

Table 5. Potential Biodiesel Production in Canada, 2007-2010 ..........................................28

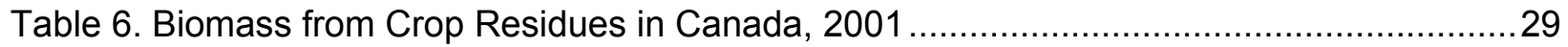

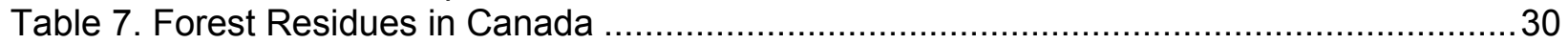

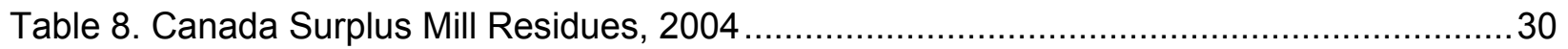

Table 9. Summary of Agricultural Residue Assessments in China .........................................44

Table 10. Summary of Forest Biomass Resource Assessments in China...............................44

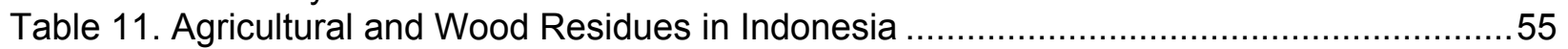

Table 12. Quantity of Waste Oil and Fats Generated in Japan ........................................58

Table 13. Annual Agricultural Residue Production in Japan .................................................59

Table 14. Annual Potential Amount of Woody Biomass in Japan (dry weight) .........................59

Table 15. Utilization of Biomass Resources in Japan, 2006 ..............................................60

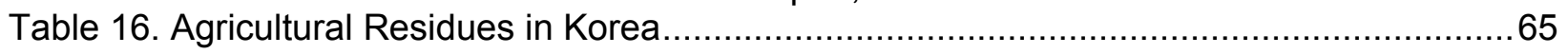


Table 17. Biomass Residue Generation in Malaysia

Table 18. Areas and Production for Select Crops in Mexico, 2004 ...................................... 72

Table 19. Areas Needed for Ethanol Production in Mexico ................................................ 73

Table 20. Agricultural Land Needed to Support Biodiesel Feedstock Production in Mexico .......74

Table 21. Lignocellulosic Biomass Potential in Mexico.................................................... 75

Table 22. Lignocellulosic Biomass Available in New Zealand, 2005-2010 ............................81

Table 23. Algae Potential from Existing Waste Streams in New Zealand................................82

Table 24. Regional Production and Use of Primary Mill Residues in New Zealand...................83

Table 25. Biodiesel Resources in Peru, 2005 ...............................................................91

Table 26. Lignocellulosic Biomass Resources in the Philippines, 2000 ...............................97

Table 27. Municipal Waste Generation in Singapore, 2007 ........................................... 104

Table 28. Agricultural Residues in Thailand, 2002-2003 ................................................ 111

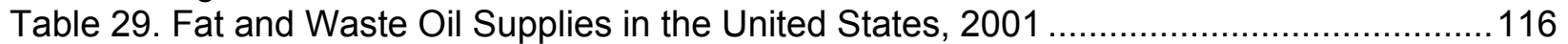

Table 30. United States Biomass Resource Assessments Inventory as of May 2008............128

Table 31. Wood and Crop Residues Available in Viet Nam, 2002 ....................................135

Table 32. Main Agricultural Residues Available by Region in Viet Nam, 2006 .....................136

Table 33. Biomass Resource Assessments in APEC Economies .....................................140

Table 34. Biomass Resource Assessment Capabilities in APEC Economies ........................141

Table 35. First-generation Resource Availability for Ethanol Production in APEC Economies. 143

Table 36. Second-generation Resource Availability for Ethanol Production in APEC Economies

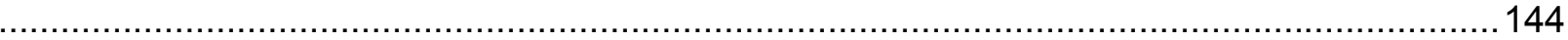

Table 37. Resource Availability for Biodiesel Production in APEC Economies ......................145 


\section{Preface}

This survey of biomass resource assessments and assessment capabilities in Asia-Pacific Economic Cooperation (APEC) economies took place from September 2007 until May 2008. Various sources were considered: academic and government publications, media reports, and personal communication with contacts in member economies. The inventoried literature was not reviewed for accuracy or modified, but simply cataloged, with the published characteristics and limitations noted. It is reasonable to assume that additional information exists for some economies, yet it was not made available due to language or access constraints.

Funding for this project was provided by APEC with additional support from the United States Department of Energy (DOE) - Office of Policy and International Affairs. 


\section{Abbreviations and Acronyms}

APEC - Asia-Pacific Economic Cooperation

BTF - Biofuels Task Force (APEC)

CRP - conservation reserve program

ETBE - ethyl tertiary butyl ether

FAO - Food and Agriculture Organization

GIS - geographic information system

GPS - global positioning system

MTBE - methyl tertiary butyl ether

MSW - municipal solid waste

NREL - National Renewable Energy Laboratory (of the U.S. Department of Energy)

PNG - Papua New Guinea

$\mathrm{RS}$ - remote sensing

R\&D - research and development

SVO - straight vegetable oil

\section{Units of Measure}

dam $^{3}$ - cubic decameter or $1,000 \mathrm{~m}^{3}$ or $10^{6} \mathrm{~L}$, described in some sources as a ML (Megaliter)

EJ - Exajoule $\left(10^{18}\right.$ joule $)$

$\mathrm{Gg}$ - Gigagram (1,000 tonnes)

ha - hectare

$\mathrm{hm}^{3}$ - cubic hectometer or $1,000,000 \mathrm{~m}^{3}$ or $10^{9} \mathrm{~L}$, described in some sources as a GL (Gigaliter)

$\mathrm{kt}$ - kilotonne (1,000 tonnes)

$\mathrm{L}$ - liter (decimeter or $\mathrm{dm}^{3}$ )

$\mathrm{m}^{3}$ - cubic meter

$\mathrm{Mt}$ - Megatonne $\left(10^{6}\right.$ tonnes $)$

MW - Megawatt

Odt - oven dry ton $=$ bone dry ton

$\mathrm{Tg}-$ Teragram, a unit of mass $=1$ Megatonne

TJ - Terajoule $\left(10^{12} \mathrm{~J}\right)$

Tonne - metric ton 
TOE - tonne of oil equivalent, the amount of energy released by burning one tonne of crude oil, approximately $42 \mathrm{GJ}$ (Gigajoule $=10^{9} \mathrm{~J}$ ); Mtoe - Million TOE

\section{Conversions}

1 metric ton of wood $=1.4$ cubic meters (solid wood)

1 metric ton of ethanol = 1,265 liters; average ethanol density: $0.79 \mathrm{~g} / \mathrm{cm}^{3}$ (= tonne $\left./ \mathrm{m}^{3}\right)$

1 metric ton of biodiesel = 1,136 liters; average biodiesel density: $0.88 \mathrm{~g} / \mathrm{cm}^{3}\left(=\right.$ tonne $\left./ \mathrm{m}^{3}\right)$

1 metric ton of gasoline $=1,356$ liters; average gasoline density: $0.73 \mathrm{~g} / \mathrm{cm}^{3}\left(=\right.$ tonne $\left./ \mathrm{m}^{3}\right)$

1 metric ton of diesel = 1,177 liters; average diesel density: $0.85 \mathrm{~g} / \mathrm{cm}^{3}$ (= tonne $/ \mathrm{m}^{3}$ )

1 metric ton of lignocellulosic biomass yields approximately 300 liters of ethanol

1 metric ton of grains yield approximately 360 liters of ethanol

\section{Glossary of Plant Names}

Chinese pistachio (Pistacia Chinensis)

Chinese tallow tree (Sapium Sebiferum)

Corn (Zea Mays) commonly known as maize

Indian mustard (Brassica Juncea)

Jatropha (Jatropha Curcas)

Maravilla (Flourensia Thurifera)

Miscanthus (a genus of about 15 species, e.g. Miscanthus Sinensis and Miscanthus giganteus)

Pongam (Pongamia Pinnata) also known as Karanj

Rapeseed (Brassica Napus) also known as Canola in the United States and Canada 


\section{Executive Summary}

Given the steady growth in the demand for transportation fuels and declining oil production within their region, the APEC economies are concerned over energy supply security and are looking for alternative options. APEC members have identified biofuels as one option for diversifying sources of energy for transport.

Biomass resource assessment is essential in evaluating the bioenergy potential in a given location, as well as the social, environmental, and economic impacts associated with resources production and use. Biomass resource assessments guide industry development strategies and support decision-making processes.

This survey aims to catalog current and planned biomass resource assessments throughout the APEC region, increasing awareness of the resource availability and identifying future needs. It also aims to understand the capability of APEC economies to undertake such assessments. It is intended to deepen and expand on the preliminary resource assessments that were presented in the APEC Biofuels Task Force (BTF) report at the Eight Energy Ministers Meeting (EMM) in Darwin, Australia in May 2007.

The results of this survey revealed that most of the APEC economies have assessed their biomass resources at an economy-wide level. Many have completed biomass resource assessments by state/province, and few at a finer geographic level - county/district or local.

Additionally, the survey found that all APEC economies have what is necessary to conduct biomass resource assessments - scientific knowledge, tools, and data. However, not all of them have used their full capabilities in existing assessments. Some members have used their advanced capabilities, such as geospatial technologies and simulation modeling to develop detailed analyses of resource potential. For others, the survey identified products that are not direct examples of biomass resource assessments, but they indicate existing capabilities that could be applied to future resource assessment projects, thus enabling them to achieve fine geographic presentation of resources and project potential.

A summary of findings is presented below. 
Economies with Good Resource-Assessment Capabilities and Detailed Resource Assessments: Australia, Canada, Chile, Indonesia, Korea, Mexico, the Philippines, Thailand, United States

Economies with Good Resource-Assessment Capabilities and Medium Scale (state/province) Resource Assessments: China, New Zealand

Economies with Good Resource-Assessment Capabilities and Broad (Economy-Wide) Resource Assessments: Japan, Malaysia, Chinese Taipei, Viet Nam

Economies with Good Resource-Assessment Capabilities and Limited or No Resource Assessments: Papua New Guinea, Peru, Russia

Economies with Limited Biofuel Resources: Brunei Darussalam, Hong Kong, Singapore

With respect to resource potential for ethanol production in the APEC region, the study concluded that a significant amount of second generation feedstock (particularly crop and forest residues) is available. This feedstock could be utilized when the technology for conversion of this material to ethanol becomes cost-effective. The feedstock amounts to about 1,700 million tonnes (Mt), which would yield some $509 \mathrm{hm}^{3(1)}$ of ethanol or $245 \mathrm{Mt}$ gasoline equivalent. Such a volume would displace about two-fifths of the region's current gasoline consumption and onefifth of its crude oil import. Many economies could substitute a substantial volume of their current gasoline consumption with ethanol from second generation feedstock, while others such as China, Thailand, and Viet Nam could substitute their entire consumption. The table below summarizes these findings.

Regarding first generation feedstock for ethanol production, the study evaluated the contribution of $20 \%$ of the economies' current starch and sugar crops production. The $20 \%$ figure is purely illustrative but would be consistent with trend-based hypotheses regarding the potential for increased agricultural yields to render a fifth of production surplus to food needs over time. If the equivalent of one-fifth of current agricultural production could actually be spared for biofuels production, the first-generation resource potential would amount to some $252 \mathrm{Mt}$ of feedstock and $92 \mathrm{hm}^{3}$ of ethanol or $44 \mathrm{Mt}$ of gasoline equivalent. This would be sufficient to displace only $7 \%$ of current gasoline consumption and $3.5 \%$ of crude oil imports in the region.

With respect to resource potential for biodiesel production, only first generation feedstock was considered. Data on second generation feedstock (non-edible crops, such as Jatropha and

\footnotetext{
${ }^{1} \mathrm{hm}^{3}$ - cubic hectometer or $1,000,000 \mathrm{~m}^{3}$ or $10^{9} \mathrm{~L}$, described in some sources as a GL (Gigaliter)
} 
Pongam, or from algae) was insufficient to provide meaningful results. If $20 \%$ of APEC economies' current vegetable oil supply could be spared for biofuel production and if all waste oils and fats could be practically gathered for such production, it would yield about 22 Mt of biodiesel. This would be sufficient to displace about $7 \%$ of current petroleum-based diesel consumption and $2 \%$ of crude oil imports. Economies with the highest resource availability include China, Indonesia, Malaysia, and the United States. It is expected that the resource potential for biodiesel production in APEC economies will increase significantly over the next years with the development of second generation feedstock.

Second-generation Resource Availability for Ethanol Production in APEC Economies

\begin{tabular}{|c|c|c|c|c|c|c|c|c|}
\hline Economy & Feedstock Type & $\begin{array}{c}\text { Resource } \\
\text { Availability } \\
\text { ('000 tonnes) }\end{array}$ & $\begin{array}{l}\text { Ethanol } \\
\text { Potential } \\
\text { (hm3) }\end{array}$ & $\begin{array}{c}\text { Gasoline } \\
\text { Equivalent } \\
\text { ('000 tonnes) }\end{array}$ & $\begin{array}{c}\text { Gasoline } \\
\text { Consumption } \\
\text { ('000 tonnes)* }\end{array}$ & $\begin{array}{c}\text { Share of } \\
\text { Gasoline } \\
\text { Consumption } \\
(\%)\end{array}$ & $\begin{array}{l}\text { Crude oil Import } \\
\text { ('000 tonnes })^{*}\end{array}$ & \begin{tabular}{|c|} 
Share of \\
Crude Oil \\
Import \\
$(\%)$
\end{tabular} \\
\hline Australia & $\begin{array}{l}\text { crop, forest, and primary } \\
\text { mill residues; urban wood } \\
\text { waste }\end{array}$ & 36,700 & 11.0 & 5,299 & 14,520 & 36.5 & 20,070 & 26.4 \\
\hline Brunei & & & & & 196 & & & \\
\hline Canada & $\begin{array}{l}\text { crop, forest, and primary } \\
\text { mill residues; hog fuel piles }\end{array}$ & 71,000 & 21.3 & 10,261 & 29,751 & 34.5 & 45,336 & 22.6 \\
\hline Chile & primary mill residues & 3,254 & 0.9 & 434 & 2,081 & 20.8 & 10,219 & 4.2 \\
\hline China & $\begin{array}{l}\text { crop, forest, and primary } \\
\text { mill residues }\end{array}$ & 788,000 & 236.0 & 113,689 & 46,097 & 246.6 & 126,817 & 89.6 \\
\hline Hong Kong & & & & & 325 & & 352 & \\
\hline Indonesia & $\begin{array}{l}\text { crop residues; sugar cane } \\
\text { bagasse; oil-palm, rubber, } \\
\text { and coconut residues }\end{array}$ & 74,000 & 22.2 & 10,695 & 12,942 & 82.6 & 20,829 & 51.3 \\
\hline Japan & $\begin{array}{l}\text { crop and forest residues; } \\
\text { urban wood waste }\end{array}$ & 15,000 & 4.5 & 2,168 & 44,391 & 4.9 & 207,266 & 1.0 \\
\hline Korea & crop and forest residues & 13,100 & 3.9 & 1,879 & 6,969 & 27.0 & 113,234 & 1.7 \\
\hline Malaysia & $\begin{array}{l}\text { crop residues; sugar cane } \\
\text { bagasse; oil-palm and wood- } \\
\text { processing residues }\end{array}$ & 32,392 & 9.7 & 4,673 & 7,756 & 60.2 & 7,885 & 59.3 \\
\hline Mexico & $\begin{array}{l}\text { crop, logging, and primary } \\
\text { mill residues }\end{array}$ & 74,500 & 22.4 & 10,767 & 27,704 & 38.9 & & \\
\hline New Zealand & $\begin{array}{l}\text { crop, logging, and primary } \\
\text { mill residues; horticultural } \\
\text { and urban wood waste }\end{array}$ & 5,500 & 1.7 & 795 & 2,325 & 34.2 & 4,488 & 17.7 \\
\hline PNG & $\begin{array}{l}\text { logging, oil-palm, and } \\
\text { coconut residues; sugar } \\
\text { cane bagasse }\end{array}$ & $N / A$ & $\mathrm{~N} / \mathrm{A}$ & $\mathrm{N} / \mathrm{A}$ & $\mathrm{N} / \mathrm{A}$ & $\mathrm{N} / \mathrm{A}$ & 435 & $\mathrm{~N} / \mathrm{A}$ \\
\hline Peru & $\begin{array}{l}\text { crop, logging, and oil-palm } \\
\text { residues; sugar cane } \\
\text { bagasse }\end{array}$ & $\mathrm{N} / \mathrm{A}$ & $\mathrm{N} / \mathrm{A}$ & $\mathrm{N} / \mathrm{A}$ & 771 & $\mathrm{~N} / \mathrm{A}$ & 4,809 & $\mathrm{~N} / \mathrm{A}$ \\
\hline The Philippines & $\begin{array}{l}\text { crop, logging, and coconut } \\
\text { residues; sugar cane } \\
\text { bagasse }\end{array}$ & 18,000 & 5.4 & 2,601 & 4,111 & 63.3 & 10,681 & 24.4 \\
\hline Russia & crop and forest residues & 100,000 & 30.0 & 14,452 & 26,260 & 55.0 & & \\
\hline Singapore & & & & & 727 & & 54,786 & \\
\hline Chinese Taipei & crop residues & 1,900 & 0.6 & 275 & 7,845 & 3.5 & 54,035 & 0.5 \\
\hline Thailand & $\begin{array}{l}\text { crop residues; sugar cane } \\
\text { bagasse; oil-palm and } \\
\text { coconut residues }\end{array}$ & 47,800 & 14.3 & 6,889 & 5,280 & 130.5 & 39,815 & 17.3 \\
\hline United States & $\begin{array}{l}\text { crop, forest, primary mill, } \\
\text { and secondary mill residues; } \\
\text { urban wood waste }\end{array}$ & 324,448 & 97.3 & 46,873 & 373,930 & 12.5 & 538,651 & 8.7 \\
\hline Viet Nam & $\begin{array}{l}\text { crop, wood-processing, and } \\
\text { coconut residues; sugar } \\
\text { cane bagasse }\end{array}$ & 93,000 & 27.9 & 13,440 & 2,546 & 527.9 & & \\
\hline APEC Total & & $1,698,594$ & 509.0 & 245,189 & 616,527 & 39.8 & $1,259,708$ & 19.5 \\
\hline
\end{tabular}

Note: Possible additional resources from dedicated energy crops are not included. 


\section{Introduction}

Biomass energy is derived from plant-based material and residues whereby solar energy has been converted into organic matter. Biomass can be used in a variety of energy-conversion processes to yield power, heat, steam, and fuel. Biomass energy sources include:

- agricultural crops and residues;

- dedicated energy crops (herbaceous and tree species);

- forestry products and residues;

- residues and byproducts from food, feed, fiber, wood, and materials processing plants [sawdust from sawmills, black liquor (a byproduct of paper making), cheese whey (a byproduct of cheese-making processes), and animal manure];

- post-consumer residues and wastes, such as fats, greases, oils, construction and demolition wood debris and other urban wood waste, municipal solid wastes and wastewater, and landfill gases.

Agricultural and forestry resource production is dependent on adequate sun, rainfall, and nutrient conditions. Depending on the climate and crop-harvesting schedule, there can be seasonal constraints on this type of resource availability and significant annual variability in resource yields at a local level. Adverse environmental conditions (e.g., hail, drought, flooding, insects, and fire) can have significant negative or positive impacts on resource availability from year to year. The concentration of population and activities in urban areas is responsible for the generation of industrial processing residues, municipal solid waste, and other urban discards. These resources may have some seasonal variability, but typically remain at consistent levels in most areas. They also tend to be more spatially concentrated.

There are competing uses for biomass resources because of their economic and environmental value for a variety of purposes. As mentioned earlier, biomass material is used to generate power, heat, steam, and for producing transportation fuels. Biomass is also used by the food processing industries, animal feed industry, and the wood products industry, which includes construction and fiber products (paper and derivatives); along with chemical products made by these industries that have diverse applications including detergents, fertilizers, and erosion control products. 


\section{Biomass Resources for Liquid Transportation Fuels}

During the past few years, there has been an increased interest in biomass resources as a feedstock for transportation fuels production. These fuels can be produced from all biomass resources listed earlier; however, the conversion technologies are at different points in their development.

First-generation feedstocks refer to currently available biomass resources converted to biofuels via well-established technologies. For ethanol production, these include starches from grains (cereals and feed) and tubers (cassava and sweet potatoes), sugars from crops (such as sugar beets, sugar cane, and sweet sorghum), and from food-processing byproducts (molasses, cheese whey, and beverage waste). First-generation biodiesel (Fatty acid methyl ester of FAME) feedstocks include vegetable oil (such as soybean, rapeseed, and palm oil), used cooking oil, and animal fat (tallow, cat fish oil, etc.).

Second-generation feedstocks refer to biomass resources either available, but not used for biofuels production at a commercial level; or resources currently not available, but proven (through R\&D activities) to have potential for biofuels production. For ethanol production, these include lignocellulosic material, such as crop and forest residues, municipal solid waste (MSW), and dedicated energy crops. The structural complexity of lignocellulosic biomass is what makes this feedstock a challenge to break down into simple sugars that can be converted to ethanol. Most plant matter consists of three key polymers: cellulose (35 to 50\%), hemicellulose (20 to $35 \%$ ), and lignin (10 to $25 \%$ ). These polymers are assembled into a complex, interconnected matrix within plant cell walls. Cellulose and hemicellulose are carbohydrates that can be broken down into fermentable sugars. Lignin is not a carbohydrate and cannot be converted into ethanol. The technical challenge is associated with separating and breaking down these different polymers. Significant R\&D efforts are under way in many APEC economies to advance this technology and use abundant lignocellulosic biomass. Lignocellulosic resources can also be catalytically processed into alcohols and Fischer Tropsch hydrocarbons via gasification to syngas, a mixture of carbon monoxide and hydrogen.

Second-generation feedstocks for biodiesel production include oils from non-edible plants, such as jatropha and pongam. More R\&D is needed to better understand these plants' biofuel potential, including their characteristics, cultivation, socio-economic, and environmental benefits. Another advanced biodiesel feedstock is microalgae, which has oil content considerably higher 
than that of oil-palm or rapeseed. However, significant technical and economic barriers need to be overcome to finish the laboratory phase, test the conversion process, develop and commercialize biodiesel from algae.

Biofuels yield per unit of land is an important consideration when choosing appropriate feedstock and making decisions for production expansion. APEC economies in the tropical biome have the advantage of growing crops with significant solar energy and rainfall input, yielding the highest biofuels per land unit compared with those in the temperate biome and its seasonal limitations. Two tropical crops, sugar cane and oil-palm, which can be used to produce ethanol and biodiesel respectively, have the highest yield per hectare among the first-generation feedstocks (Figures 1-2). APEC economies are among the world's leading producers of these crops. China, Mexico, Thailand, Australia, and Indonesia are well established sugar cane producers and among the top 10 suppliers in the world. Indonesia, Malaysia, and Thailand are the world's largest palm oil producers. The Philippines are the world's largest coconut oil producer. Given the favorable climate conditions and significant labor availability, Southeast Asian economies have announced feedstock production expansion and large-scale biofuels programs.

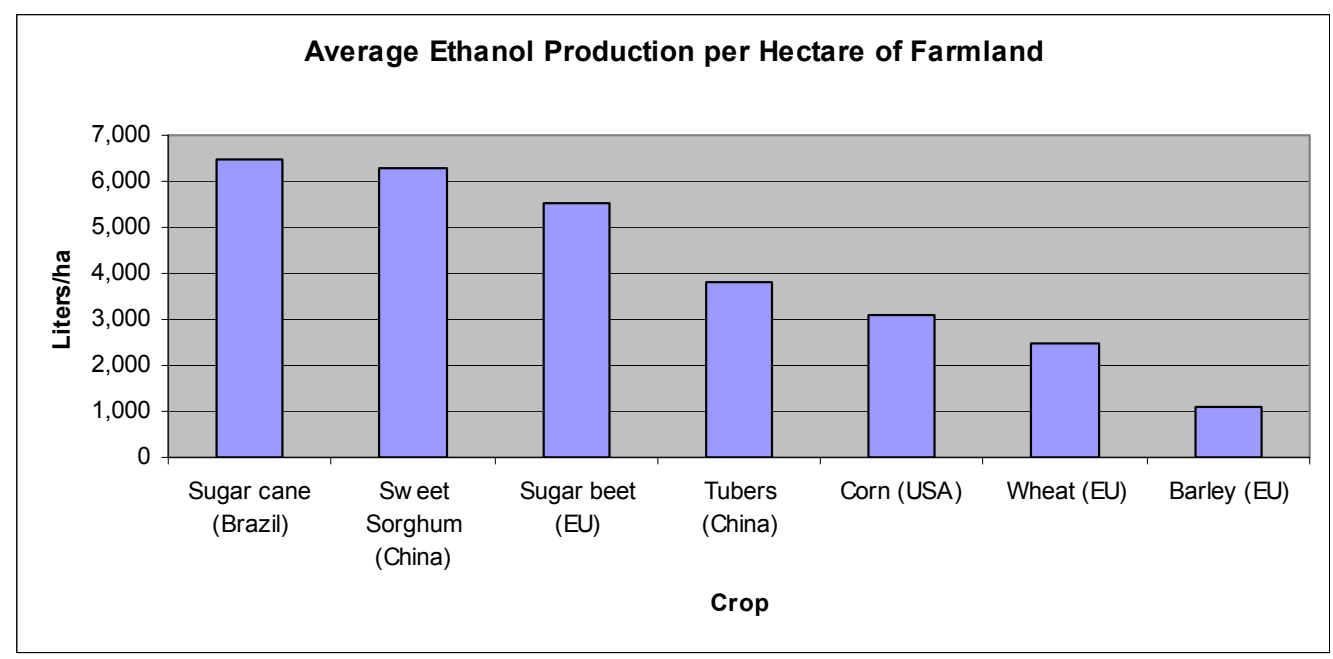

Source: Worldwatch Institute, 2007; USDA, GAIN Biofuels Report for China, 2007

Figure 1. Average Ethanol Production per Hectare of Farmland Yield by Crop 


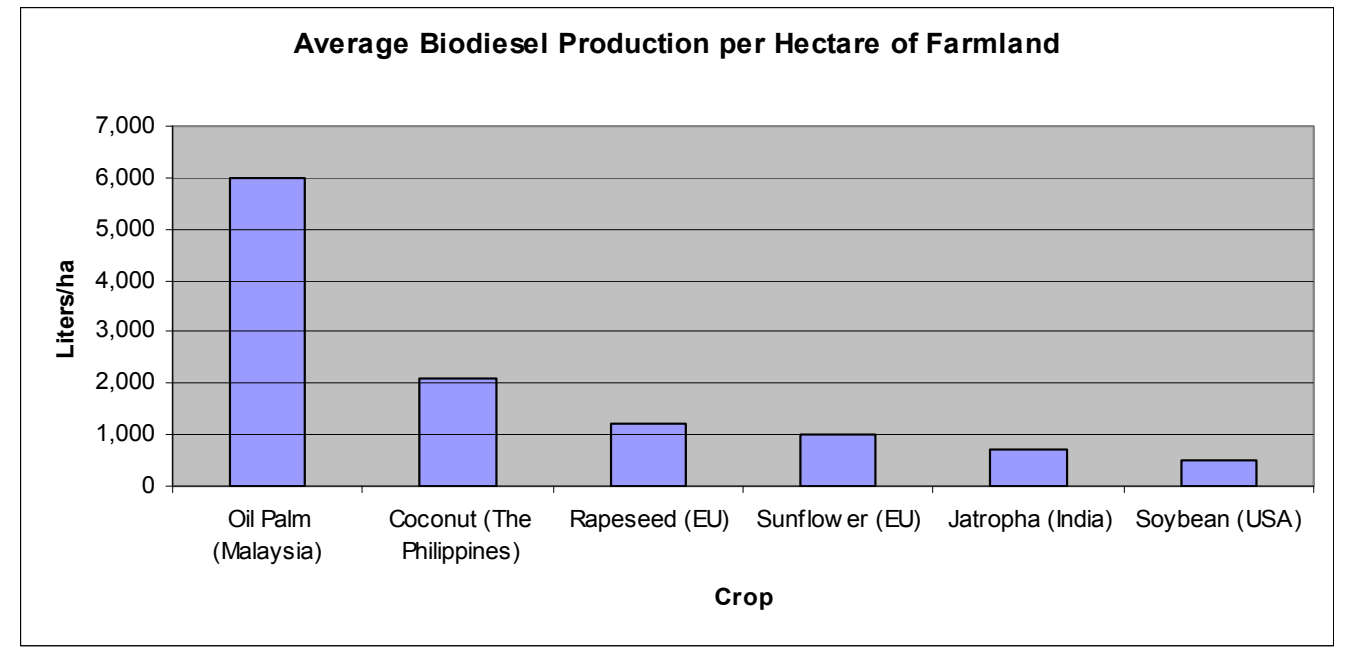

Source: Worldwatch Institute, 2007

Figure 2. Average Biodiesel Production per Hectare of Farmland Yield by Crop

\section{Project Background and Objectives}

Accounting for about $60 \%$ of world energy demand, the APEC region is a net energy importer with its annual consumption exceeding domestic production. Energy imports to APEC economies are projected to increase by approximately 92\% between 2000 and 2020 driven by economic growth, industrialization, and urbanization. According to the Asia-Pacific Energy Research Center, APEC's transport energy demand is projected to double from 2002 to 2030, and the transport sector is expected to account for more than $70 \%$ of APEC's incremental oildemand growth. Given the steady growth in the demand for transportation fuels and declining oil production within the region, the APEC economies are concerned over supply security and are looking for alternative options. APEC members have identified biofuels as one option for diversifying sources of energy for transport.

The Seventh APEC EMM in Gyeongju, Korea, (October 2005) endorsed a three-pronged approach to cope with increasing oil prices and oil-import dependency, including enhanced exploration and development, improved fuel economy in transport, and increased use of alternative fuels including biofuels. The APEC Biofuels Task Force, established in May 2006 at ministers' direction, has a remit to examine issues related to biofuel resources, infrastructure requirements, economics and trade. The task force reported to EMM-8 in Darwin, Australia, in May 2007 that biofuels from a variety of feedstocks are cost-competitive with petroleum-based fuels, that biofuels can reduce greenhouse gas emissions, and that biofuels can displace a 
significant percentage of petroleum use over time, especially as advanced technologies are developed for use of lignocellulosic biomass such as crop and forest residues. This survey is intended to deepen and expand on the preliminary resource assessments that were presented in that report. ${ }^{2}$

The project aims to understand what biomass resource assessments have been undertaken in APEC economies, as well as the capability of APEC economies to undertake such assessments. Considering that every economy maintains statistics on grain, sugar, and oil crops they produce - and the controversy surrounding the use of these crops for biofuels production - the project pays particular attention to assessments of alternative (non-food) biomass resources, including lignocellulosic biomass, waste vegetable oil and animal fats, and dedicated energy crops.

Many APEC economies have completed biomass resource assessments, but are not aware of the range of resource assessments conducted in other APEC economies. Furthermore, industry developers may be unaware of resource assessments that have been conducted in their area of interest. As interdependency increase among the APEC members, this information is critical to moving forward the biofuels technology in the region. The project aims to catalog current and planned biomass resource assessment products throughout the APEC region, increasing awareness of their availability and identifying future needs.

Some APEC economies have extensive capabilities to assess biomass resources - methods, tools, data, and scientific knowledge - but, there is no common understanding of such capabilities in others. The project gives APEC economies a shared view of their capabilities to systematically assess biofuel resources and suggest practical ways to improve these capabilities so that the resource potential can be better understood.

\footnotetext{
2 APEC BTF Report to the Eight Energy Ministers Meeting, Darwin, Australia, May 2007, http://www.ewg.apec.org/assets/documents/apecinternet/Biofuelsreport\%5FEMM820071011104537\%2E $\underline{\mathrm{pdf}}$
} 


\section{Biomass Resource Assessment Products and Assessment Methodologies}

Biomass resource assessment is essential in evaluating the bioenergy potential in a given location, the social and environmental impacts associated with resources production and (most important) the economic feasibility of biomass utilization scenarios. Biomass resource assessments guide industry development strategies and support decision-making processes.

Biomass resource assessment products have different information characteristics and applicability. These products can be presented in a different format: tabular, graphic (charts or graphs), geographic (maps), or as analytical tools and software products. The assessments vary depending on the purpose and the level of detail required. The purpose of an assessment is to identify resource potential within a given area for a particular end use: power, heat, steam, or transportation fuel. There are three types of biomass resource potential: theoretical, technical, and economic, that build on each other in providing a comprehensive view of biomass energy opportunities.

- Theoretical - Illustrates the ultimate resource potential based on calculation or measurement of the net primary productivity of the biome.

- Technical - Limits the theoretical resource potential by accounting for terrain limitations, land use and environmental considerations, collection inefficiencies, and a number of other technical and social constraints. This type of potential is also called accessible biomass resource potential.

- Economic - It is a subset of technical resource potential that applies economic parameters, which estimate the cost of biomass resources either at the field or forest edge. The final outcome of this type of assessment is a supply curve (\$/tonne).

The level of detail varies between biomass resource assessments. High-level, aggregated information - such as assessments at economy-wide, regional, and state/province level - are usually required by policy makers. Whereas more detailed information at a county/district or site-specific level is required by energy planners and project developers.

The purpose of a biomass resource assessment and the level of detailed required dictate the method employed to assess biomass resources. The current evaluation methods include geospatial technologies, field surveys, and modeling. 
Geospatial Technologies. These include remote sensing (RS), geographic information systems (GIS), and global positioning systems (GPS). Remotely sensed images, such as aerial and satellite images, provide an efficient and reliable way to monitor biomass resources over time. Remote sensing images have relatively fine spatial and temporal resolutions, similar to the data obtained by field surveys. These products range in spatial resolution from as coarse as every degree of latitude and longitude to as fine as every six meters, and can be at repeatable time scales. RS is the only technique available to monitor biomass resources at local, regional and global scales. This technique is used to estimate growing stock of biomass and forecast its productivity. RS provides a cost-efficient way to collect the required information at areas that are remote and poorly accessible. Remote sensing images are also the only practical approach to analyze land use and land cover change at economy-wide, regional, and global scales. Their patterns can be studied by comparing images acquired at different times. Figure 3 illustrates an example of high-resolution remote sensing images.

Data derived from remote sensing images, such as land use/cover, elevation, and surface temperature, is further used in geographic information systems (GIS). GIS is a computer-based information system used to create, manipulate, analyze, and visualize geographically referenced information. It is a powerful tool for assessing biomass potential: It integrates many different types of data and provides a means of examining their spatial relationships. The concept of data overlaying in GIS is shown in Figure 4. GIS is particularly useful in estimating technical biomass resource potential by integrating various datasets such as crop/forest production statistics, land use, terrain, transportation infrastructure, and protected areas. It also can identify areas where the agro-climatic conditions are suitable for growing a particular crop or assess biomass resources available within a certain radius from a processing facility. 


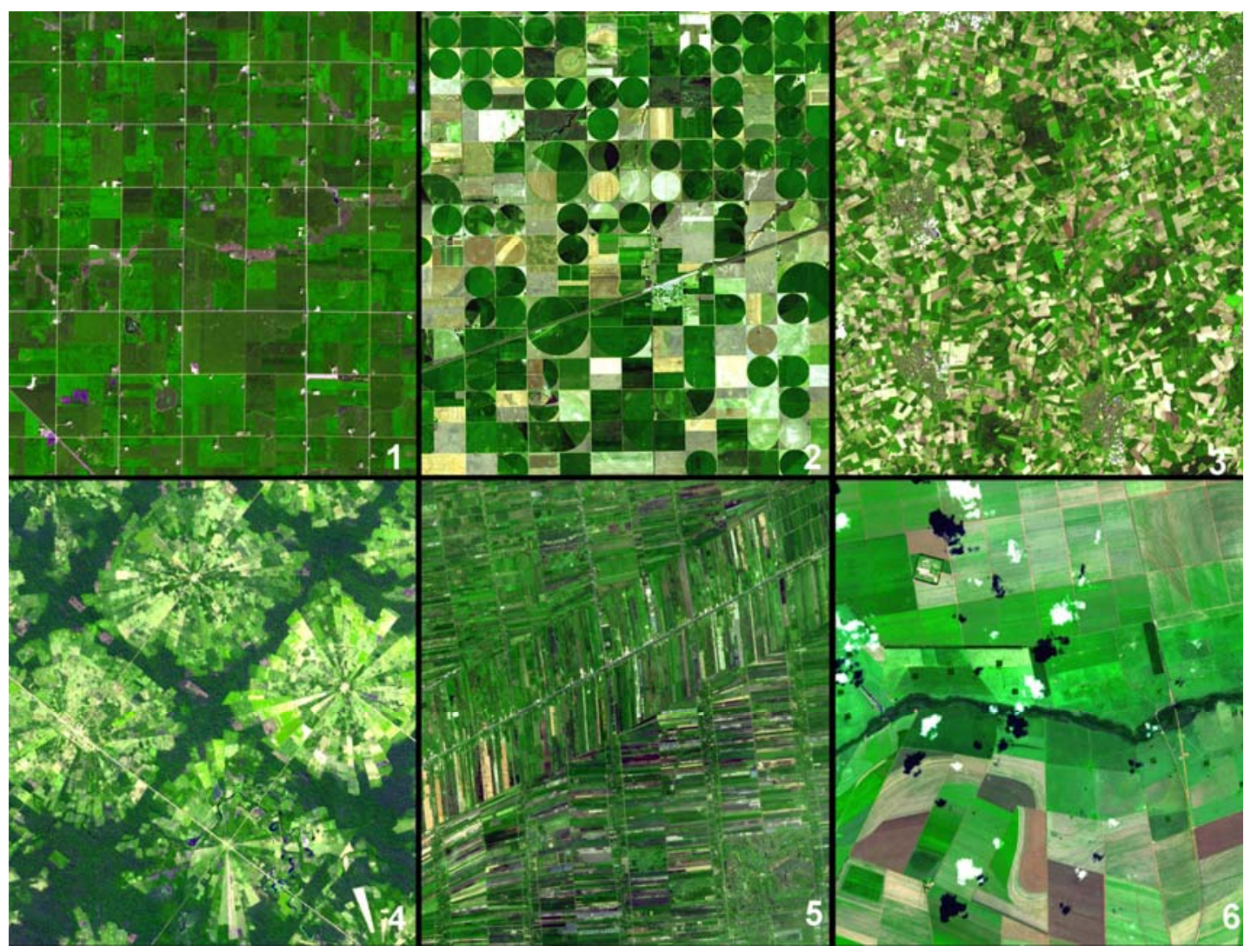

Source: NASA/GSFC/METI/ERSDAC/JAROS and U.S./Japan ASTER Science Team ${ }^{3}$; Aster sensor, multi-spectral, 15m Each ASTER sub-image covers an area of 10.5 × 12 km; 1 - Minnesota, USA; 2 - Kansas, USA; 3 - Northwest Germany; 4 - Santa Cruz, Bolivia; 5 - Bangkok, Thailand; 6 - Cerrado, Southern Brazil.

Figure 3. Agricultural Fields Around the World

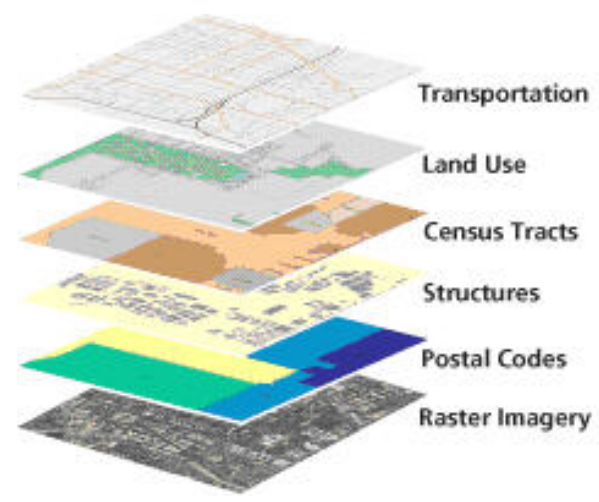

Source: Fire Program Analysis (FPA), http://www.fpa.nifc.gov

Figure 4. Conceptual Model of GIS

\footnotetext{
${ }^{3}$ ASTER (Advanced Spaceborne Thermal Emission and Reflection Radiometer) is an imaging instrument flying on Terra, a satellite launched in December 1999 as part of NASA's Earth Observing System, http://asterweb.jpl.nasa.gov/gallery-detail.asp?name=agmontage
} 
Surveys. Field surveys are used to collect data as part of site-specific evaluation. Usually, a field plot (the size can vary) is selected as representative of the vegetation type in a study area, and parameters such as stem diameter, tree height, or crown dimensions for forest resources and density, height, and phenological development for crops are easily measured. The results are further extrapolated over a larger area and used to develop equations that predict biomass availability. This sampling technique provides the most accurate estimate of biomass resources at a given location; however, it is not practical for broad scale inventory. It is a time-consuming, labor-intensive, and therefore costly procedure, even with today's satellite communication technology (GPS). Data collected by the GPS operations can be automatically recorded with a GIS program to further analyze the data or validate model-derived estimates. Currently, field surveys in biomass resource assessments are used when other methods prove insufficient or when capabilities to use other methods don't exist.

Another way of collecting field data is sending questionnaires to farmers and cooperatives and asking them to report information such as planted acres, harvested yield, harvesting methods, and water management (irrigation or no irrigation). But this method of collecting field data relies on voluntary participation, creating a potential for informational gaps. Information can also be collected by face-to-face and telephone interviews, which are only applicable to local surveys; otherwise, it could be a time-consuming process. The "paper" survey method is often used for collecting crops-related information while the sampling technique described above is usually applied in forest resource estimates.

Modeling. Models are simplified frameworks designed to illustrate a system or process often using mathematical techniques to facilitate calculations or predictions. The complexity of a model and the modeling technique depend on the needs of the assessment and data availability. Models can be as simple as extrapolating measured data using statistical methods, or as complex as balancing numerous processes (organized in separate modules) to derive resource characteristics.

Both, static (analytical) and dynamic (simulation) models are used in biomass resource assessments. Static models describe a system mathematically, in terms of equations, and can be built in a spreadsheet. An example is estimating the amount and cost of crop residues (rice straw for example) by specifying values (usually averages) for several variables such as crop production, residue generation, labor cost, and prices (chemical, fertilizer, fuel, and planting). 
Simulation models describe a system dynamically over time and are built using specific software. While static models ignore time-based variances and the synergy of the components of the system, dynamic models explore "what-if" scenarios and the sensitivity of a system to variations in its different components as time progresses. For example, simulation techniques can be used in a crop-simulation model to examine the effects of climate, soil, and management practices on crop production. Another example is the use in biomass resource elasticity studies to examine the effect of land use change, market price, and policy measures on feedstock supply. When combined with optimization algorithms, simulations can indicate what policy choices or other decisions may lead to particular desired outcomes.

A more advanced, and perhaps the most comprehensive, type of modeling is the integration of simulation techniques with GIS to capture temporal and spatial perspectives of a system together. For example, incorporating soil type, climate, land use and road network information with advanced transportation and economic models, it is possible to predict both where dedicated energy crops could be grown and their marginal cost. Depending on the purpose of the model and input data resolution, the GIS system allows visualization of the outcome at different geographic levels - regional, sub-regional, economy-wide, state, provincial, municipal, or site specific.

In the past, using the modeling method for biomass resource assessments has been criticized for relying on highly simplified assumptions. Today however, simulation models allow examining the theoretical consequences of more complex assumptions. Increased computational power and speed of today's computers has vaulted dynamic modeling ahead of static modeling as the method of choice, and made it possible to improve intuition about the feedback and interaction among regions, sectors, and other components of the biomass "landscape". Moreover, data are becoming organized into common databases at finer levels of granularity and sharing data has never been easier. Micro-data can now support micro-simulations. It is possible to compute large-scale micro-simulation models that would not have been possible just a few of years ago. 


\section{Australia}

\section{Economy-Wide Biomass Resource Assessments}

Australia has developed a number of biomass resource assessments considering conventional and advanced biofuels feedstock. The most recent study was developed by Australia's Commonwealth Scientific and Industrial Research Organization (CSIRO) for the Rural Industries Research and Development Corporation (RIRDC) in May 2007. The study calculated the amount of ethanol and biodiesel from first- and second-generation feedstocks, as well as the percentage of petroleum products they could replace. The study looked at different scenarios: all domestic crop production converted to biofuels, export fraction of domestic crop production converted to biofuels, and potential ethanol production from lignocellulosic biomass. The study also investigated the implications of an economy-wide E10 (blend of 10\% ethanol with gasoline) target. This is a study at an economy-wide level with no finer geography.

\section{First-Generation Biofuels Potential}

Ethanol: Ethanol in Australia is produced mainly from sorghum, wheat, and sugar cane. Feedstock supply regions are primarily the grain belt (primarily the south and southeast) and the east coast, where the sugar cane is grown. The study by CSIRO evaluated the feedstock availability in Australia and estimated the volume of ethanol that could be produced under two scenarios: first, if all grains and sugars are converted to ethanol and second, if the export portion of these crops is used. Table 1 provides the results of CSIRO's study.

If $20 \%$ of Australia's current starch and sugar crops production could be used for biofuels (about $9 \mathrm{Mt}$ in 2005), it would yield about $3.11 \mathrm{hm}^{3}$ of ethanol or $1.5 \mathrm{Mt}$ gasoline equivalent. This volume would replace $10.3 \%$ of Australia's current gasoline consumption and $7.5 \%$ of crude oil import.

Biodiesel: Animal fats, used cooking oil, and canola are the available biodiesel feedstock in Australia. The study by CSIRO evaluated the availability of these resources and similarly to ethanol estimated the biodiesel production potential under the two scenarios (Table 2).

If $20 \%$ of Australia's current vegetable oil production (about 39,000 tonnes in 2005), as well as the export portion of waste oils and fats, are used for biofuels, it would yield about $379 \mathrm{Mt}$ of 
biodiesel. This volume would replace $5 \%$ of the economy's current diesel consumption and $2 \%$ of crude oil import.

Table 1. Upper Limits to Ethanol Production Using Current Domestic Feedstock Supply Systems in Australia

\begin{tabular}{|c|c|c|c|c|c|c|c|}
\hline \multirow[b]{2}{*}{ Feedstock } & \multirow[b]{2}{*}{$\begin{array}{l}\text { Conv } \\
(\mathrm{L} / \mathrm{t})\end{array}$} & \multicolumn{3}{|c|}{$\begin{array}{l}\text { Scenario I - All domestic crop production } \\
\text { converted to ethanol }\end{array}$} & \multicolumn{3}{|c|}{$\begin{array}{l}\text { Scenario II - Export fraction of domestic } \\
\text { crop production converted to ethanol }\end{array}$} \\
\hline & & \begin{tabular}{|l|} 
Australian \\
production \\
(Mt)
\end{tabular} & $\begin{array}{l}\text { Ethanol all } \\
\text { feedstock } \\
\text { (ML) }\end{array}$ & \begin{tabular}{|l|} 
Blend \\
(\% 04-05 petrol \\
replacement ${ }^{\text {) }}$
\end{tabular} & Export (Mt) & $\begin{array}{l}\text { Ethanol export } \\
\text { feedstock (ML) }\end{array}$ & $\begin{array}{l}\text { Blend } \\
\text { (\% 04-05 } \\
\text { petrol energy }{ }^{F} \text { ) }\end{array}$ \\
\hline Sugar & $560^{\mathrm{E}}$ & $\begin{array}{l}5.0 \\
(4.2-5.5)^{\wedge}\end{array}$ & \begin{tabular}{|l}
2800 \\
$(2352-3080)$
\end{tabular} & $\begin{array}{l}\text { E14 } \\
(9 \%)\end{array}$ & $\begin{array}{l}3.8 \\
(3.1-4.2)^{\wedge}\end{array}$ & $\begin{array}{l}2128 \\
(1736-2352)\end{array}$ & $\begin{array}{l}\text { E11 } \\
(7 \%)\end{array}$ \\
\hline $\begin{array}{l}\text { C- } \\
\text { molasses }\end{array}$ & $270-290^{\circ}$ & $0.6-1.2^{\mathrm{B}}$ & 280 & $\begin{array}{l}<\mathrm{E} 2 \\
(0.9 \%)\end{array}$ & $0.5^{\mathrm{a}}-0.82 \mathrm{E}$ & $140-220$ & $\begin{array}{l}<\mathrm{E} 1 \\
(0.05 \%)\end{array}$ \\
\hline Wheat & $360^{\circ}$ & $\begin{array}{l}20.6 \\
(10.1-26.1)^{\wedge}\end{array}$ & $\begin{array}{l}7419 \\
(3648-9408)\end{array}$ & \begin{tabular}{|l} 
E38 \\
$(24.5 \%)$
\end{tabular} & $\begin{array}{l}14.8 \\
(9.1-17.9)^{\wedge}\end{array}$ & $\begin{array}{l}5337 \\
(3278-6432)\end{array}$ & $\begin{array}{l}\text { E27 } \\
(18 \%)\end{array}$ \\
\hline $\begin{array}{l}\text { Coarse } \\
\text { grain }\end{array}$ & 360 & $\begin{array}{l}11.3 \\
(6.9-15.6)^{\wedge}\end{array}$ & $\begin{array}{l}4083 \\
(2493-5637)\end{array}$ & $\begin{array}{l}\text { E20 } \\
(14 \%)\end{array}$ & $\begin{array}{l}5.5 \\
(3.8-7.2)^{\wedge}\end{array}$ & $\begin{array}{l}1978 \\
(1355-2587)\end{array}$ & $\begin{array}{l}\text { E10 } \\
(7 \%)\end{array}$ \\
\hline TOTAL & & & 14,857 & \begin{tabular}{|l}
$E 78$ \\
$(50 \%)$
\end{tabular} & & $\begin{array}{l}9690 \\
(6509-11771)\end{array}$ & $\begin{array}{l}\text { E50 (E33-E60) } \\
(22-40 \%)\end{array}$ \\
\hline
\end{tabular}

${ }^{\text {A }}$ ABARE Australian Commodity Statistics 2005, 2000-01 to 2004-05 data used; ${ }^{\text {B }}$ Beer et al 2003; ${ }^{\mathrm{D}}$ Rutowitz 2005; ${ }^{\mathrm{E}}$ Australian Cane growers Council 2005; ${ }^{\mathrm{2}} 2004-05$ petrol usage of $19500 \mathrm{ML}$. Note: The first figure reported describes the ethanol blend that could be supported, while the bracketed figure corrects for the lower energy content of ethanol relative to petrol (0.66). Source: CSIRO, 2007

Table 2. Upper Limits to Biodiesel Production Using Current Domestic Feedstock Supply Systems in Australia

\begin{tabular}{|c|c|c|c|c|c|c|c|}
\hline \multirow[b]{2}{*}{ Feedstock } & \multirow[b]{2}{*}{ ConvL/t } & \multicolumn{3}{|c|}{$\begin{array}{l}\text { Scenario I - All domestic crop production } \\
\text { converted to biodiesel }\end{array}$} & \multicolumn{3}{|c|}{$\begin{array}{l}\text { Scenario II - Export fraction of domestic } \\
\text { crop production converted to biodiesel }\end{array}$} \\
\hline & & $\begin{array}{l}\text { Australian } \\
\text { production (kt) }\end{array}$ & $\begin{array}{l}\text { Biodiesel all } \\
\text { feedstock } \\
(\mathrm{ML})\end{array}$ & $\begin{array}{l}\text { Biodiesel } \\
\text { blend } \\
\text { supported }\end{array}$ & Export (kt) & \begin{tabular}{|l|} 
Biodiesel \\
feedstock \\
No domestic \\
use (ML) \\
\end{tabular} & $\begin{array}{l}\text { Biodiesel } \\
\text { blend } \\
\text { supported }^{\text {B }}\end{array}$ \\
\hline $\begin{array}{l}\text { Waste } \\
\text { cooking oil - } \\
\text { Australia }\end{array}$ & $870^{\wedge}$ & $90-105^{\wedge}$ & $90-105 \mathrm{~A}$ & B0.6 & & $90-105^{\wedge}$ & B0.6 \\
\hline $\begin{array}{l}\text { Tallow - } \\
\text { Australia }\end{array}$ & $894^{\wedge}$ & \begin{tabular}{|l|}
500 \\
Lo grade 260 \\
Hi grade $240^{\wedge}$
\end{tabular} & 447 & B2 & $340^{\wedge}$ & 304 & B2 \\
\hline $\begin{array}{l}\text { Oilseed } \\
\text { crops (incl. } \\
\text { canola, } \\
\text { cottonseed } \\
\text { and others) }\end{array}$ & 400 & $\begin{array}{l}2533 \\
(1532-3094)^{\wedge}\end{array}$ & $\begin{array}{l}1013 \\
(613-1238)\end{array}$ & B7 & $\begin{array}{l}1498 \\
(887-2189)^{\wedge}\end{array}$ & $\begin{array}{l}599 \\
(355-876)\end{array}$ & B4 \\
\hline $\begin{array}{l}\text { TOTAL for } \\
\text { Australia }\end{array}$ & & & $\begin{array}{l}1,538 \\
(1132-1769)\end{array}$ & B10 & & \begin{tabular}{|l}
903 \\
$(659-1180)$
\end{tabular} & $\begin{array}{l}\text { B6 } \\
(4-8 \%)\end{array}$ \\
\hline
\end{tabular}

${ }^{\text {A }}$ Beer et al (2005); ${ }^{B}$ A correction for energy content is not required for biodiesel; Note: B10 equates to $10 \%$ replacement of $2004-05$ diesel energy. Source: CSIRO, 2007; Note: the tabulated values are taken directly from the source - the unit ML means $10^{6} \mathrm{~L}_{\text {or }} 1 \mathrm{dam}^{3}$ 


\section{Second-Generation Biofuels Potential}

Ethanol: The study by CSIRO evaluated the potential for ethanol production from secondgeneration feedstock in Australia. It estimated the amount of lignocellulosic biomass generated annually in Australia as well as the reasonable amount that could actually be collected (Table 3). The "reasonable available fraction" of biomass resources amount to about $36.7 \mathrm{Mt}$ per year. These include $30 \mathrm{Mt}$ of crop residues, 1.2 Mt of urban wood waste, $0.65 \mathrm{Mt}$ of wood processing residues, $1 \mathrm{Mt}$ of plantation residues, 1.35 Mt of forest residues, and $2.5 \mathrm{Mt}$ of forest thinning. This amount would yield $11 \mathrm{hm}^{3}$ of ethanol or $5.2 \mathrm{Mt}$ gasoline equivalent, and it would replace $36 \%$ of current gasoline consumption and $26 \%$ of crude oil import.

Biodiesel: Alternative oilseed crops, such as pongam, jatropha, and Indian mustard, have been considered for biodiesel production in Australia, particularly for marginal lands.

Researchers from the Faculty of Agriculture, Food and Natural Resources at the University of Sydney assessed the marginal lands in Australia and found that 20-30 million hectares are potentially suitable for the production of exotic biofuel crops, namely pongam, jatropha, and Indian mustard. The authors estimate that even if a small fraction of the marginal lands is used for these crops production, it will provide enough feedstocks to supply up to $50 \%$ of the economy diesel needs (Odeh and Tan 2007). The marginal agricultural regions of mainland Australia are illustrated in Figure 8. These marginal regions are outside the grain belt in southern Australia and tropical rainforests in northern Australia. The criteria used to delineate these regions include a plant productivity index, as derived by the Australian Greenhouse Office. The "productivity index" model is based on the relationship between the amount of photosynthetically active radiation absorbed by plant canopies (APAR) and the various productivity modifiers that affect plant growth (e.g., temperature, soil water content, frost). The model used a monthly time-step to derive both a long-term average monthly productivity index ( $250 \mathrm{~m}$ resolution) and a monthly productivity index for 1970 to 2002 (1 km resolution) (Kesteven et al. 2004). Table 4 illustrates the location and extent of the areas suitable for exotic biofuel crops. It should be noted, however, that this is a theoretical study and in dept analysis would be needed to determine the marginal land that could actually be developed for biofuels. Moreover, jatropha is declared a highly invasive weed and it is banned in parts of Australia. Considering the uncertainty surrounding the alternative oilseed crops cultivation in the economy they have not been considered in this study. 
Table 3. Upper Limits to Biofuels Production Using Second-generation Feedstock Resources in Australia

\begin{tabular}{|c|c|c|c|c|c|c|c|}
\hline Feedstock & $\begin{array}{l}\text { Conv. } \\
\text { (L/t) }\end{array}$ & $\begin{array}{l}\text { Australian } \\
\text { production } \\
\text { (Mt) }\end{array}$ & $\begin{array}{c}\text { Ethanol from } \\
\text { all feedstock } \\
\text { (ML) }\end{array}$ & $\begin{array}{c}\text { Reasonable } \\
\text { available fraction } \\
\text { (Mt) }\end{array}$ & $\begin{array}{l}\text { Ethanol from } \\
\text { reasonable } \\
\text { available } \\
\text { fraction (ML) }\end{array}$ & $\begin{array}{c}\text { Ethanol } \\
\text { blend } \\
\text { (\% 04-05 } \\
\text { petrol energy) }\end{array}$ & $\begin{array}{c}\text { Electricity } \\
\text { (TWh) }\end{array}$ \\
\hline $\begin{array}{l}\text { Crop } \\
\text { residues }\end{array}$ & 300 & $\begin{array}{l}53.1 \\
(23.4-79.1)^{A}\end{array}$ & \begin{tabular}{|l|}
13,148 \\
$(5852-19561)^{A}$
\end{tabular} & $\begin{array}{l}30^{\mathrm{B}} \\
(28-37)\end{array}$ & $\begin{array}{l}9,000 \\
(8400-11100)\end{array}$ & $\begin{array}{l}\text { E43-E57 } \\
(28-37 \%)\end{array}$ & \\
\hline $\begin{array}{l}\text { Annual } \\
\text { and } \\
\text { perennial } \\
\text { grasses }\end{array}$ & 300 & $10-20^{B}$ & $3000-6000$ & $\begin{array}{l}\text { NAD but have } \\
\text { assumed } 5 \% \text { as } \\
\text { there is already } \\
\text { an existing market }\end{array}$ & $150-300$ & $\begin{array}{l}\text { E0.7-E1.5 } \\
(<1 \%)\end{array}$ & \\
\hline $\begin{array}{l}\text { Sawlogs } \\
\text { and } \\
\text { pulpwood }\end{array}$ & $\begin{array}{l}200- \\
280\end{array}$ & $\begin{array}{l}14 \\
(9-19)^{c}\end{array}$ & $\begin{array}{l}3,300 \\
(1800-5200)\end{array}$ & $\begin{array}{l}\text { NAD but assume } \\
\text { biomass currently } \\
\text { exported as woodchip } \\
\text { could be available }\end{array}$ & $\begin{array}{l}1,400 \\
(900-2000)\end{array}$ & $\begin{array}{l}\text { E5-E10 } \\
(3-7 \%)\end{array}$ & $\begin{array}{l}28 \\
(13-120)\end{array}$ \\
\hline $\begin{array}{l}\text { Urban } \\
\text { wood } \\
\text { waste }\end{array}$ & $\begin{array}{l}200- \\
280\end{array}$ & $3.3-4^{D}$ & $660-1200$ & $\begin{array}{l}\text { No data but } \\
\text { assume } 30 \% \\
\text { recovery }\end{array}$ & $200-360$ & $\begin{array}{l}\text { E1-E1.7 } \\
(<2 \%)\end{array}$ & \\
\hline $\begin{array}{l}\text { Waste } \\
\text { from wood } \\
\text { processing } \\
\text { facilities }\end{array}$ & $\begin{array}{l}200- \\
280\end{array}$ & $\begin{array}{l}1.3 \\
(1-5)^{E}\end{array}$ & $\begin{array}{l}700 \\
(400-1000)\end{array}$ & $\begin{array}{l}\text { NAD but assume } \\
50 \% \text { could be } \\
\text { available }\end{array}$ & $\begin{array}{l}350 \\
(200-500)\end{array}$ & $\begin{array}{l}\text { E1.8 } \\
(1)\end{array}$ & $1.3(1.0-1.5)$ \\
\hline Firewood & $\begin{array}{l}200- \\
280\end{array}$ & $\begin{array}{l}5.0 \\
(4-22)^{F}\end{array}$ & $\begin{array}{l}1,200 \\
(1000-5500)\end{array}$ & $\begin{array}{l}\text { NAD but assume } \\
10 \% \text { as there is } \\
\text { already an existing } \\
\text { market }\end{array}$ & $100-550$ & $\begin{array}{l}\text { E0.5-E2.8 } \\
(<2 \%)\end{array}$ & $0.5(0.1-2)$ \\
\hline $\begin{array}{l}\text { Plantation } \\
\text { residues - } \\
\text { current }\end{array}$ & $\begin{array}{l}200- \\
240\end{array}$ & $\begin{array}{l}2.1 \\
(1.5-2.8)^{G}\end{array}$ & $\begin{array}{l}500 \\
(300-700)\end{array}$ & $\begin{array}{l}\text { No data but } \\
\text { assume } 50 \% \\
\text { can be colleted } \\
\text { economically }\end{array}$ & $\begin{array}{l}250 \\
(150-350)\end{array}$ & $\begin{array}{l}\text { E0.7-E1.7 } \\
(<2 \%)\end{array}$ & $\begin{array}{l}3.1 \\
(1.7-13.1)\end{array}$ \\
\hline $\begin{array}{l}\text { Native } \\
\text { forest } \\
\text { residues }\end{array}$ & $\begin{array}{l}200- \\
300\end{array}$ & $\begin{array}{l}2.7 \\
(1.6-3.7)^{\mathrm{H}}\end{array}$ & $300-1100$ & $\begin{array}{l}\text { No data but } \\
\text { assume } 50 \% \\
\text { can be collected }\end{array}$ & $150-500$ & $\begin{array}{l}\text { E0.7-E2.6 } \\
(<2 \%)\end{array}$ & $\begin{array}{l}4.1 \\
(1.4-17.2)\end{array}$ \\
\hline $\begin{array}{l}\text { Native } \\
\text { forest } \\
\text { thinning }\end{array}$ & $\begin{array}{l}200- \\
300\end{array}$ & $2.5(1-4)^{\mathrm{H}}$ & $250-1300$ & $\begin{array}{l}\text { No data but assume } \\
100 \% \text { would be } \\
\text { used for biofuels }\end{array}$ & $250-1300$ & $\begin{array}{l}\text { E1.3-E6.8 } \\
(1-4 \%)\end{array}$ & $4(1-20)$ \\
\hline Black liquor & & $0.25 \mathrm{~m}^{3}$ & NAD & & & & \\
\hline $\begin{array}{l}\text { New oilseed } \\
\text { species eg } \\
\text { Pongamia, } \\
\text { Moringa }\end{array}$ & & NAD & NAD & NAD & NAD & NAD & \\
\hline Algae & & NAD & NAD & NAD & NAD & NAD & \\
\hline $\begin{array}{l}\text { Future } \\
\text { mallee- } \\
\text { eucalypt } \\
\text { crop }\end{array}$ & $\begin{array}{l}200- \\
300^{\prime}\end{array}$ & $(2-100)$ & $(400-30000)$ & $\begin{array}{l}\mathrm{NAD} \text { - assume all } \\
\text { available }\end{array}$ & $(400-30000)$ & $\begin{array}{l}\text { E2-E85+ } \\
(3-100 \%)\end{array}$ & $\begin{array}{l}18 \\
(2-500)\end{array}$ \\
\hline $\begin{array}{l}\text { Future } \\
\text { hardwood } \\
\text { plantation } \\
\text { growth }\end{array}$ & $\begin{array}{l}240- \\
300^{j}\end{array}$ & $14(7-24)$ & $\begin{array}{l}3,800 \\
(2000-7000)\end{array}$ & $\begin{array}{l}\text { NAD - assume } \\
25 \% \text { of pulpwood } \\
\text { and } 50 \% \text { of } \\
\text { harvesting residue } \\
\text { could be available }\end{array}$ & $\begin{array}{l}1,000 \\
(500-2000)\end{array}$ & $\begin{array}{l}\text { E2.5-E10 } \\
(1.7-7 \%)\end{array}$ & $\begin{array}{l}6 \\
(2-31)\end{array}$ \\
\hline
\end{tabular}

${ }^{A}$ CSIRO estimate from APSIM modeling unpublished data; ${ }^{\text {B }}$ Higgins 2006 9; ${ }^{\mathrm{C}}$ ABARE 2006; ${ }^{\mathrm{D}}$ FWPRDC 2006, MBAC 2004; ${ }^{\mathrm{E}} \mathrm{MBAC} 2004$, Raison 2006; ${ }^{\mathrm{F}}$ Freudenberger et al 2004; ${ }^{\mathrm{G}} \mathrm{CSIRO}$, Ensis unpublished data; ${ }^{\mathrm{H}}$ Raison 2006; ' Foran 1999, Bartle 2001, 2006, Grove etg al 2005; ${ }^{\mathrm{J}}$ Based on future expected harvest and residue amounts minus current harvest and residue amounts; NAD = No Appropriate Data

Source: CSIRO, 2007; Note: the tabulated values are taken directly from the source - the unit ML means $10^{6} \mathrm{~L}$ or $1 \mathrm{dam}^{3}$ 


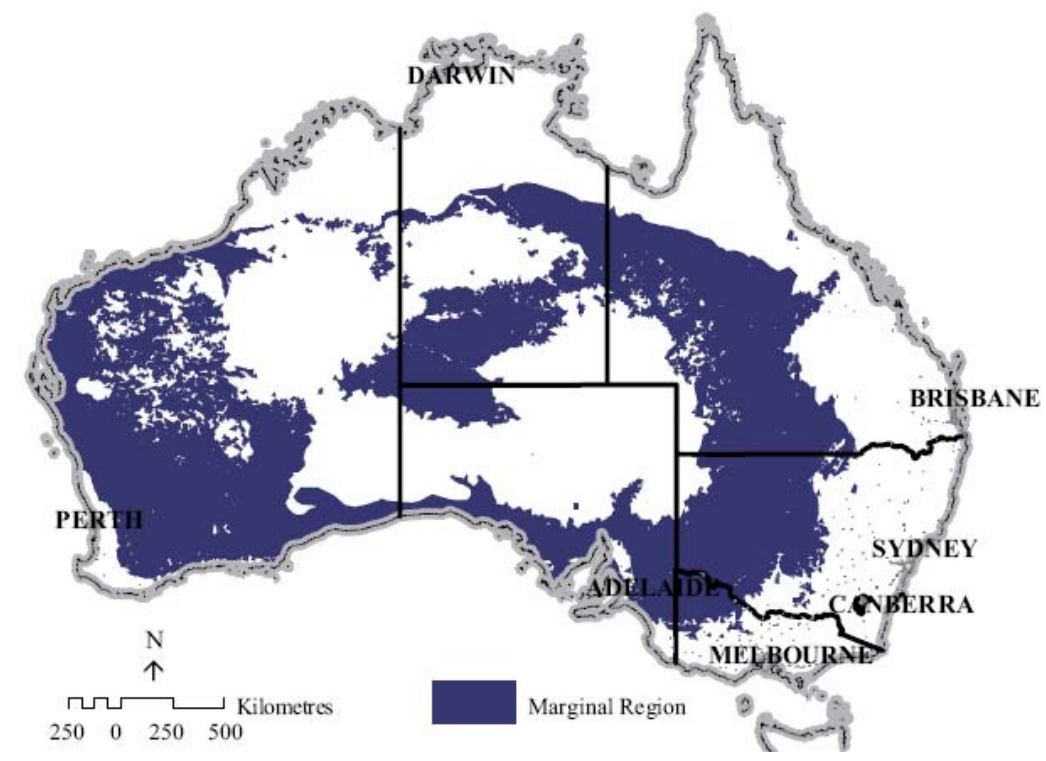

Source: Odeh and Tan 2007

Figure 5. The Marginal Agricultural Regions of Australia

Table 4. Marginal Lands for the Production of Exotic Biofuel Crops in Australia

\begin{tabular}{|c|c|c|c|}
\hline & Approximate Locations of Suitable Regions & $\begin{array}{l}\text { Area } \\
\text { (Mha) }\end{array}$ & $\begin{array}{l}\text { \% Australia's } \\
\text { Land Mass }\end{array}$ \\
\hline Pongam & $\begin{array}{l}\text { Mostly in central north Queensland (QLD) } \\
\text { near Mt Isa and Longreach, and areas north of } \\
\text { Tennant Creek in the Northern Territory (NT). } \\
\text { There is a substantial area east of Port Hedland } \\
\text { in northwest Western Australia (WA). }\end{array}$ & 20.06 & 2.6 \\
\hline Physic nut & $\begin{array}{l}\text { Substantially in the area east of Mt Isa, extend- } \\
\text { ing north-west of the town to north-east of } \\
\text { Tennant Creek in NT. There is a considerable } \\
\text { area between Port Hedland and Newman in WA } \\
\text { that is suitable for this crop. }\end{array}$ & 23.47 & 3.1 \\
\hline $\begin{array}{l}\text { Indian } \\
\text { mustard }\end{array}$ & $\begin{array}{l}\text { While some suitable areas for Indian mustard } \\
\text { found in central north QLD and north-west WA } \\
\text { overlap with the areas suitable for both pongam } \\
\text { and physic nut, Indian mustard can be grown in } \\
\text { areas as far south as southern New South Wales } \\
\text { around Hay, extending into Victoria. }\end{array}$ & 31.7 & 4.2 \\
\hline
\end{tabular}

Source: Odeh and Tan 2007; Note: the area unit of Mha identified in the table is from the original source and is considered to be $10^{6}$ ha or a unit of $10,000 \mathrm{~km}^{2}$ 


\section{Regional and Local Biofuels Resource Assessments}

A finer level of detail is achieved with the online Bioenergy Atlas of Australia, an interactive tool that provides access to maps and information on existing and potential biomass resources as well as existing industry locations, infrastructure and other key data. The project was undertaken jointly by the Bureau of Rural Sciences and University of Adelaide with funding provided by the Rural Industries Research and Development Corporation under the Joint Venture AgroForestry Program and the Australian Greenhouse Office. The Atlas uses GIS technology to illustrate the quantity and spatial distribution of biomass resources. It provides estimates for the following biomass categories:

Agricultural residues. This includes in-field resources remaining after harvesting, and postprocessing resources (biomass material remaining at the facility after the processing of sown pastures, rice, cottonseed, etc.). The estimates are presented within a Statistical Local Area (SLA) region, distributed using land use patterns (at $1 \mathrm{~km}$ resolution), or at processing sites. These estimates are based on 1996 crop production statistics. An example of the agricultural resources presented in the Atlas is shown in Figure 5.

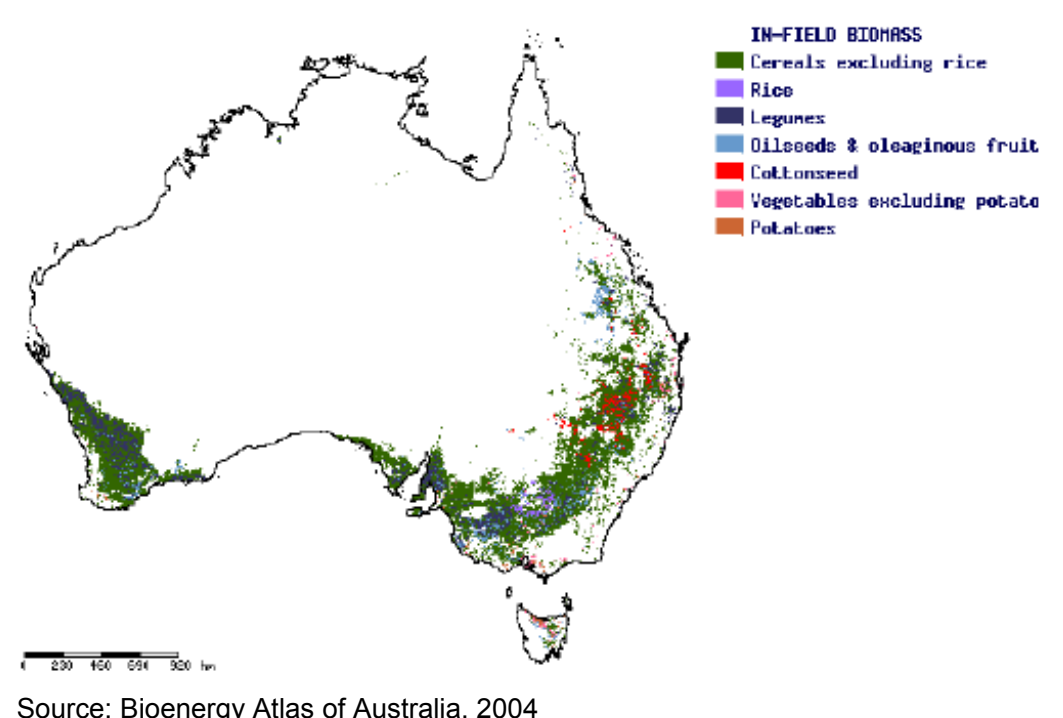

Figure 6. In-field Biomass Resources in Australia

Forest residues. This includes resources from native forests and plantations, as well as estimates of potential production from plantations on capable and suitable land. The estimates are presented within a SLA region, distributed using land use patterns (at 250 meter and $1 \mathrm{~km}$ 
resolution), or at processing sites. These estimates are based on 1999-2001 statistics. An example of the agricultural resources presented in the Atlas is shown in Figure 6.

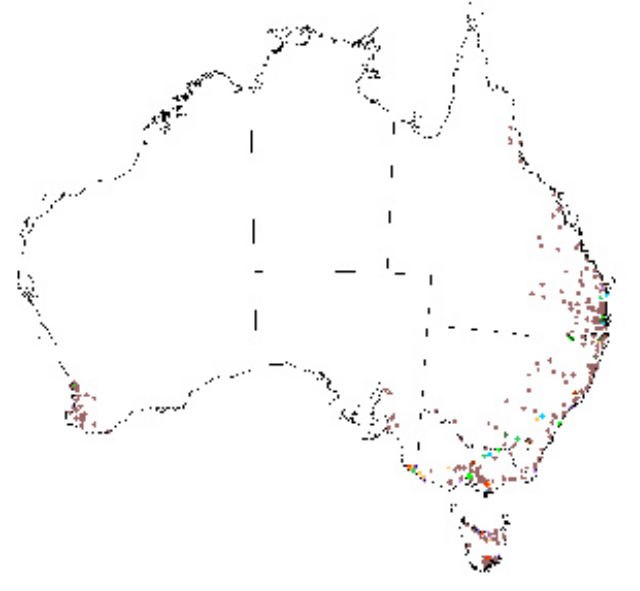

Wood Processing (by type)

Source: Bioenergy Atlas of Australia, 2004

- Chip Export

- Chip Mill

Hardboard

- Log Export

- LUL

- MDF

- Paper

- Particleboard

- Plynood/Veneer

- Post/Poles

- Pulp

- Pulp/Paper

- Saunill

- Value Added

Figure 7. Wood Processing Mills in Australia

Potential tree crops for salinity hazard reduction. This dataset shows potential tree growth on cleared private land where a salinity hazard exists. It is designed to show where revegetation may provide benefits for salinity hazard reduction. The estimates were developed by analysis of climate, land use (at 250 meter resolution), and potential productivity of suitable species. Figure 7 depicts the location of salinity hazard lands and their tree production potential.

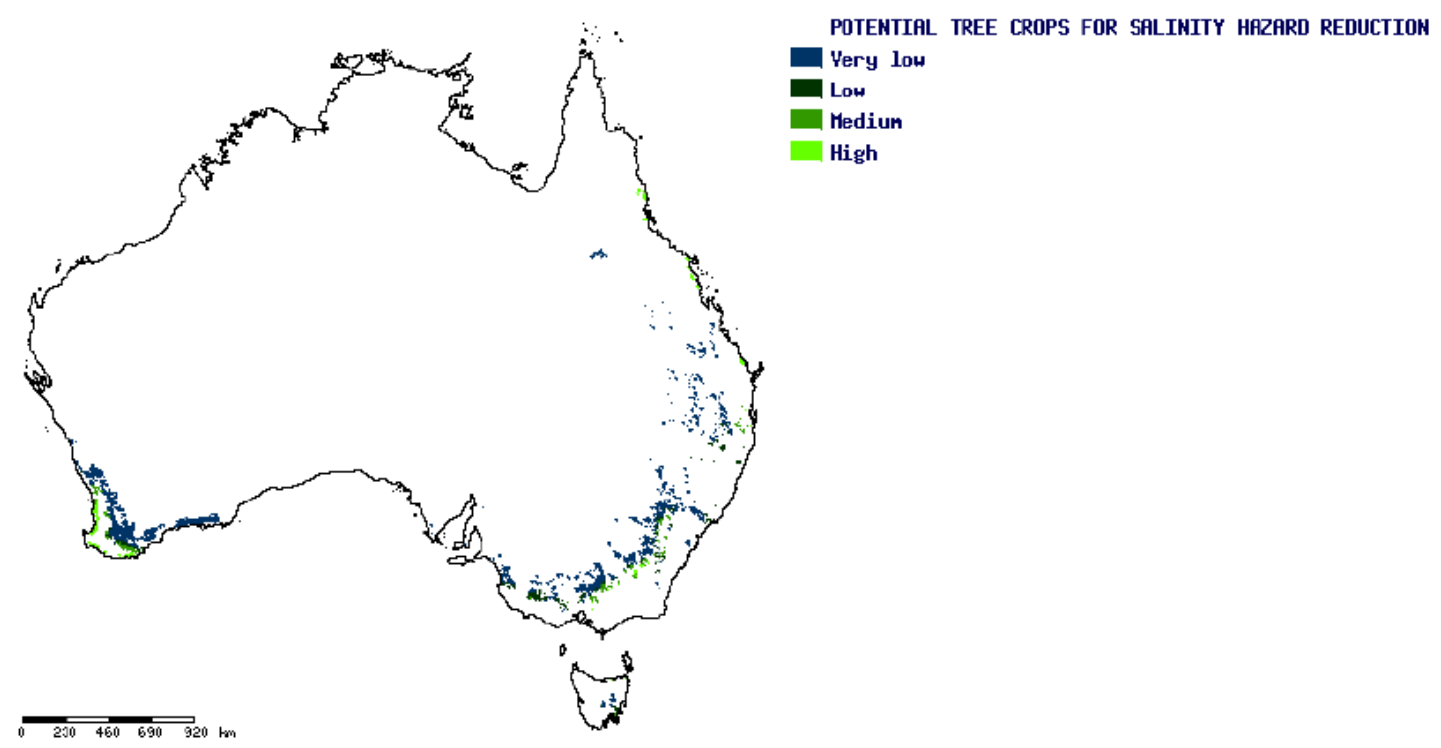

Source: Bioenergy Atlas of Australia, 2004

Figure 8. Potential Tree Crops for Salinity Hazard Reduction in Australia 


\section{Biomass Resource Assessment Capabilities}

Australia has strong capabilities in assessing biomass resources as illustrated above. The economy has used the full range of resource assessment methods: geospatial technologies, modeling, and survey techniques. In addition, spatial and temporal data are readily available to support future work in the area.

Geospatial technologies such as remote sensing and GIS are extensively used by the academic, government, and private institutions in Australia. A direct example of applying these technologies in assessing biomass resources is the Bioenergy Atlas of Australia, described above. In addition to the Atlas, the Bureau of Rural Sciences (BRS) has produced other interactive tools and models to help agricultural, fishing, and forestry industries make decisions. These include the National Agricultural Monitoring System (NAMS), which contains a range of climatic and production information for dry land/ broad acre and irrigated industries, for more than 600 regions throughout Australia; the Integrated Vegetation Online tool which illustrates the distribution of major vegetation cover types in Australia (native forests and grasslands and nonnative vegetation); and the Rainfall Reliability Wizard, which uses data since January 1900 to estimate rainfall reliability, rainfall means, and rainfall variability. The full list of products by BRS can be viewed at http://www.daff.gov.au/brs/data-tools.

Remote sensing and GIS techniques are also largely used by the Australian Greenhouse Office (AGO) and CSIRO's Terrestrial Mapping and Monitoring group in estimating and monitoring vegetation productivity and land use/cover change for carbon accounting. AGO developed the National Carbon Accounting System (NCAS) which estimates the greenhouse gas emissions from land-based sectors. This GIS-based system integrates various datasets (remotely sensed land cover change, land use and management, climate and soil data), tools (greenhouse gas accounting tools), and ecosystem modeling. NCAS determines carbon stock changes at a fine spatial (25m resolution) and temporal scale (10 sequences of land cover change from 1972 to 2000) nationally. A list of products and technical reports developed by AGO is provided at http://www.greenhouse.gov.au/ncas/publications/index.html.

Dynamic modeling is largely used in Australia. In 1990, the Queensland State Government and CSIRO established a joint research team, the Agricultural Production Systems Research Unit (APSRU) that combines expertise in the computer simulation of farming systems and facilitates agricultural production research. One simulation model designed by APSRU is the 
Agricultural Production Systems sIMulator (APSIM). The model simulates biophysical processes in farming systems, particularly in relation to the economic and ecological outcomes of management practices in the face of climate risk. APSIM is structured around plant, soil, and management modules. It resulted from a need for tools that provide accurate predictions of crop production in relation to climate, genotype, soils, and management factor while addressing the long-term resource management issues. APSIM can simulate more than 20 crops and forests (e.g., alfalfa, eucalyptus, cowpea, pigeon pea, peanuts, cotton, lupin, maize, wheat, barley, sunflower, sugar cane, chickpea, and tomato). Key outputs include crop and pasture yields, yield components, and soil erosion losses for different climate change scenarios. APSIM outputs are site specific but can be linked to GIS for spatial analysis at different geographic scales - economy-wide, state, and regional. Other agricultural simulation models developed by APSRU are listed at http://www.apsru.gov.au/apsru/.

Surveys and Data Availability. Sample survey techniques are used by CSIRO to generate the Biomass Database, a project funded by the $A G O$ and the Joint Venture Agroforestry Program (JVAP), which is supported by three R\&D corporations - Rural Industries Research and Development Corporation (RIRDC), Land \& Water Australia (L\&WA), and Forest and Wood Products Research and Development Corporation (FWPRDC), together with the Murray-Darling Basin Commission (MDBC). The database provides fuel and energy characteristics for biomass material sourced from agriculture (wheat straw, cotton trash, bagasse, poultry litter, etc), municipal (municipal solid waste in various forms including some involving sewage, refusederived fuel, green waste, wood waste), woody (from different forestry operations including some irrigated by effluent), and industrial sources (timber mills, etc). Representative samples of biomass were collected and analyzed in terms of their ultimate, proximate, ash, combustion (fouling and corrosion), and gasification characteristics, as well as their suitability for ethanol (liquid fuel) production. The database is available through the Bioenergy Atlas, which will allow the resource ( $\mathrm{t} / \mathrm{ha}$ ) to be linked with fuel characteristics $(\mathrm{MJ} / \mathrm{kg}$ ), providing energy density information on different regions in Australia. The biomass database can be accessed at http://www.det.csiro.au/science/energyresources/biomass.htm

Paper surveys are used by government agencies in Australia to collect information related to agricultural commodities: cereals and other broad-acre crops, vegetables, fruits, vineyards, and livestock. The most relevant agencies are the Australian Bureau of Statistics (ABS) and Australian Bureau of Agricultural and Resource Economics (ABARE). These agencies provide 
time-series data at different geographic levels. ABS conducts an Agricultural Survey (AS) annually; and approximately every fifth year, an Agricultural Census is conducted in place of the AS. The Agricultural Survey collects area and production data for a wide range of agricultural commodities at the establishment level. The collected information can be further aggregated to larger geographic units such as Statistical Local Area (SLA), Statistical Division (SD), or State/Territory. The spatial extent of these units varies. More information on these spatial units can be found at http://www.abs.gov.au/.

ABARE has conducted surveys of selected Australian agricultural industries since the 1950s. ABARE surveys collect detailed financial, physical, and socioeconomic information from farm businesses across Australia. Surveys include the Australian agricultural and grazing industries survey (AAGIS) and Australian dairy industry survey (ADIS). AAGIS includes the following five broad-acre industries: wheat and other crops (farms engaged mainly in growing cereal grains, coarse grains, oilseeds, and/or pulses), mixed livestock-crops, sheep, beef, and sheep-beef industries. The ADIS survey includes primarily dairy farms. The data collected is presented interactively by region, agricultural zone, or state in AGsurf

(http://www.abare.gov.au/interactive/agsurf/). ABARE also has been collecting irrigation data as part of its annual broad-acre and dairy industries surveys since 1987-88.

Information about Australia's forests is collected by many different organizations, including Commonwealth, state and territory land management agencies and private companies. The scale at which such information is collected and the methodology used often differ between agencies, the tenure of land and the purpose of collection. To standardize these data sources and to allow them to be combined and directly compared, a National Forest Inventory (NFI) partnership was developed between the Commonwealth and all state and territory governments. The states and territories undertake on-the-ground collection of forest data, while the Commonwealth provides funding for the data integration and dissemination. The NFI encompasses a wide range of forest-related data, from the most detailed site data to the broadest Australia-wide summaries. It covers public and private forests, and native and plantation forests. It collates information about a wide range of forest characteristics such as their type, location, distribution, height, crown density, growth stage and/or planting date, ownership, and protection status. The NFI holds datasets on other forest attributes including soils, administrative boundaries, climate, mineral deposits, topography, rare and endangered species, and social and economic aspects. NFI is based in Canberra at the Bureau of Rural 
Sciences, a research bureau of the Commonwealth Department of Agriculture, Fisheries and Forestry (DAFF). BRS also maintains two other inventories - the National Farm Forest Inventory and the National Plantation Inventory - both relying on reported information by farm forest and plantation owners. More information on the BRS products related to forest, plantation, and vegetation resources is available at http://www.daff.gov.au/brs/forest-veg. A list of agencies and organizations involved in forestry research is maintained by the DAFF at http://www.daff.gov.au/forestry/contacts.

Overall Biomass Resource Assessment Capabilities. It is evident from the summary above that Australia has very strong capabilities in conducting biomass resource assessments: relevant data is collected systematically, various methods and tools are applied in existing resource assessments or in relevant fields, and knowledgeable personnel is available through many agencies and organizations to undertake such efforts. However, continued work is needed to improve the quality of existing products. The study completed by CSIRO in May 2007 uses up-to-date statistics, but it is a nationwide study with no finer geography. Finer geography is achieved in the Bioenergy Atlas of Australia, but the data on feedstock quantity is out of date (1996). To address this knowledge gap, the economy is launching a new initiative called Sustainable Biomass Production for Bioenergy and Biofuels in Australia. This effort plans to coordinate all biomass resource assessment activities in the economy and provide detailed and up to date products.

\section{References}

1. Agricultural Production Systems Research Unit (APSRU), http://www.apsru.gov.au/apsru/

2. Australian Bureau of Agricultural and Resource Economics (ABARE). Forestry and wood product statistics: September and December Quarters 2005, www.abare.gov.au

3. Australian Bureau of Statistics (ABS), www.abs.gov.au

4. Australian Cane Growers Council, Submission to Prime Minister's Biofuels Taskforce. Submission No. 50 June 2005, http://www.pmc.gov.au/biofuels/report/appendices all.pdf

5. Australian Greenhouse Office (AGO), http://www.greenhouse.gov.au/ncas/publications/index.html

6. Bartle, J., New Perennial Crops: Mallee Eucalypts - a Model, Large Scale Perennial Crop for the Wheatbelt. Outlook 2001: Proceedings of the National Outlook Conference, 27 February - 1 March, 2001Canberra, Australia: Vol. 1: Natural Resources, pp 117-128.

7. Bartle, J., New Non-Food Crops and Industries for Australian Dryland Agriculture. Green Processing 2006: 63-68.

8. Beer, T., Grant, T. and Korn,W., Environmental Sustainability Issues in Relation to Biodiesel. CSIRO Atmospheric Research, Aspendale, VIC, Australia. Report no. Restricted Access Report HK58K/1/F3.5, 2005. 
9. Bioenergy Atlas of Australia, Bureau of Rural Sciences, University of Adelaide, March 2004, http://adl.brs.gov.au/mapserv/biomass/index.phtml

10. Biofuels Taskforce, Report of the Biofuels Taskforce to the Prime Minister. Department of the Prime Minister and Cabinet, 2005, Australian Government, Canberra, Australia.

11. Bureau of Rural Sciences (BRS), http://www.daff.gov.au/brs/data-tools

12. CSIRO, Biofuels in Australia - issues and prospects, May 2007, http://www.rirdc.gov.au/reports/EFM/07-071.pdf

13. CSIRO, Biomass Database, http://www.det.csiro.au/science/energyresources/biomass.htm

14. Department of Agriculture, Fisheries and Forestry (DAFF), http://www.daff.gov.au

15. Foran, B. and Mardon, C., Beyond 2025: Transitions to a Biomass-Alcohol Economy Using Ethanol and Methanol. CSIRO Wildlife and Ecology, Canberra, Australia. Report no. 99/07, 1999.

16. Forest \& Wood Products Australia (FWPA), http://www.fwprdc.org.au/index.asp

17. Freudenberger, D., Cawsey, E. M., Stol, J. and West, P. W., Sustainable firewood supply in the Murray-Darling Basin. CSIRO Report to the Australian Department of Environment \& Heritage. CSIRO, Canberra, Australia, 2004.

18. Higgins, P., Report for Grains Research and Development Corporation: Possibilities for biomass ethanol. Emergent Futures, Grains Research and Development Corporation, Canberra, Australia, 2006.

19. Kesteven, J, Landsberg, J \& URS Australia, Developing a National Forest Productivity Model, National Carbon Accounting System Technical Report No. 23, Australian Greenhouse Office, 2004, http://www.greenhouse.gov.au/ncas/reports/pubs/tr23final.pdf

20. MBAC Consulting Pty Ltd., Potential wood flows, technical and scale issues and identification of sustainable management criteria. National Association of Forest Industries, Canberra. Report No. 3, 2004.

21. Odeh I, Tan D, Expanding Biofuel Production in Australia: Opportunities Beyond the Horizon. Farm Policy Journal 4, 29-39, May 2007.

22. Raison, R. J., Opportunities and Impediments to the Expansion of Forest Bioenergy in Australia. Biomass and Bioenergy, Volume 30, Issue 12, 2006.

23. Rutovitz, J. and Passey, R. NSW Bioenergy Handbook. Mark Ellis \& Associates, Sydney, Australia, 2004.

24. Taylor, J., Mann, R., Reilly, M., Warnken, M., Pincic, D. and Death, D., Recycling and end-of-life disposal of timber products. Forest and Wood Products Research and Development Corporation, Melbourne, Australia. Project No. PN05.1017, 2005. 


\section{Brunei Darussalam}

Despite being a significant regional producer of oil and natural gas, Brunei Darussalam is considering diversifying its energy portfolio and following the global trend in search of alternative energy sources such as biofuels. No biomass resource assessment was identified at the time this survey took place. Statistical information on crop and forestry production in Brunei is provided annually by the Department of Agriculture and the Forestry Department (also includes monthly reports). Considering some general information on land use, however, it is unlikely that Brunei will produce biofuels feedstock domestically. The economy is more than 527,000 ha about 2.3\% (12,000 ha) is arable land and about $53 \%(278,000 \mathrm{ha})$ is forest. Rice production is low (only about 1,000 tonnes per year), and Brunei imports more than $80 \%$ of its requirements. Other crops grown, mostly for home consumption, include banana, sweet potato, cassava, coconut, pineapple, and vegetables. The timber industry is well established and the harvest volume is carefully controlled by the Forestry Department on a planned renewable basis. Timber production has been limited to just 100,000 cubic meters a year. The economy most likely will pursue overseas investments in feedstock production and import either the raw material or fuel.

\section{References}

1. Department of Agriculture, accessed March 2008, http://www.agriculture.gov.bn/

2. FAO, Food and Agriculture Indicators - Brunei Darussalam, November 2006, http://www.fao.org/ES/ess/compendium 2006/pdf/BRU ESS E.pdf

3. Forestry Department, accessed March 2008, http://www.forestry.gov.bn/ 


\section{Canada}

\section{Economy-Wide and Provincial Biofuels Resource Assessments}

\section{First-Generation Biofuels Potential}

Ethanol: In Canada, ethanol is produced almost entirely from cereals (corn and wheat). Corn accounted for $77 \%$ of all ethanol feedstock in 2006 . This percentage is expected to decrease in coming years due to more wheat-based plants under construction. Corn production was about 9 Mt in 2006, $7 \%$ of which was used for ethanol production. The majority of domestically produced and imported corn is used by the livestock industry. Wheat production in Canada is much higher, more than $20 \mathrm{Mt}$ annually. Being the world's second-largest exporter of wheat, after the United States, the majority of this production goes for export (about $17 \mathrm{Mt}$ annually). Less than $1 \%$ was used for ethanol production in 2006.

If the equivalent of $20 \%$ of Canada's current starch and sugar crops production could be made available for biofuels, for example through increase in crop yields over time, it would yield about $2.18 \mathrm{hm}^{3}$ of ethanol or $1 \mathrm{Mt}$ gasoline equivalent per annum. This volume would be sufficient to replace $3.5 \%$ of Canada's current gasoline consumption and $2.3 \%$ of its crude oil imports.

Biodiesel: The Canadian Canola Growers Association (CCGA) estimated that Canada could produce about 500 million litres (approximately 440,000 tonnes) of biodiesel from domestic feedstock in the 2007-2010 timeframe (Table 5). This volume would replace more than $3 \%$ of the current diesel consumption, based on the International Energy Agency (IEA) estimate of 12.5 Mt of diesel consumed in 2005. CCGA's estimate is at a economy-wide level with no finer geography presented.

If the equivalent of $20 \%$ of Canada's current vegetable oil production could be spared for biofuels production, as well as all waste oils and fats, it would yield about $0.55 \mathrm{Mt}$ of biodiesel per annum. Such an amount could displace $4.4 \%$ of the economy's current diesel consumption and $1.2 \%$ of its crude oil imports. 
Table 5. Potential Biodiesel Production in Canada, 2007-2010

\begin{tabular}{|l|c|}
\hline Source & Biodiesel Production \\
\hline Tallow & 160 million litres \\
\hline Yellow Grease & 80 million litres \\
\hline Canola & 220 million litres \\
\hline Soybeans & 40 million litres \\
\hline TOTAL FORECAST & $\mathbf{5 0 0}$ million litres \\
\hline
\end{tabular}

Source: CCGA 2006

\section{Second-Generation Biofuels Potential}

BIOCAP Canada Foundation estimated agricultural crop residues in 2001 (BIOCAP 2003). Total crop production was about $78.3 \mathrm{Mt}$ in 2001 , of which $70 \%$ was wheat, barley, or tame hay. Crop residues (straw and stover) were estimated at 56.1 Mt (using crop-to-residue ratio), some of which must be left on the field to maintain soil fertility and carbon content. Residues recoverable and sustainably removable were estimated at $29.3 \mathrm{Mt}$ annually; however, some of this goes to traditional uses such as animal bedding and mulching. The study concluded that agricultural biomass available for energy may be $18 \mathrm{Mt}$ annually (Table 6).

An analysis by Climate Change Solutions in 2007 estimated the harvest residues available in the key forest provinces (Table 7). In some provinces, much of this material is burned at roadside, both to prevent uncontrolled forest fires and also to clear more land for forest renewal. British Columbia $(\mathrm{BC})$ has the largest harvest, at 87 million $\mathrm{m}^{3}(\sim 62 \mathrm{Mt})$, and slash residues. $\mathrm{BC}$ is followed by Quebec in harvest, with 40 million $\mathrm{m}^{3}$ ( $\left.29 \mathrm{Mt}\right)$. In most of the provinces slash is $9-14 \%$ of the harvest volumes; however, in BC slash volumes are currently $20-40 \%$ of harvest, a phenomenon of the massive harvest of mountain pine beetle (MPB) wood. The MPB population has undergone an unprecedented explosion in BC, spreading from 25,000 hectares (ha) in 1994 to more than 7 million ha in 2004 . Of this area, $26 \%$ suffered moderate mortality and $11 \%$ suffered severe mortality. As a result of the outbreak, dead timber in 2004 is estimated at 170 million $\mathrm{m}^{3}(\sim 121 \mathrm{Mt})$. The annual kill is projected to peak in 2008 at 70 million $\mathrm{m}^{3}(\sim 50 \mathrm{Mt})$ with more than 450 million $\mathrm{m}^{3}$ ( $321 \mathrm{Mt}$ ) projected to be killed by this time. The outbreak may last for 10 years and kill $80 \%$ of merchantable pine (Climate Change Solutions 2006). 
Table 6. Biomass from Crop Residues in Canada, 2001

\begin{tabular}{|c|c|c|c|c|c|c|c|c|c|}
\hline \multirow{3}{*}{ Crop } & \multicolumn{6}{|c|}{ Yield of Crops and Crop Residues } & \multicolumn{3}{|c|}{ Currently Available Residues } \\
\hline & \multirow{2}{*}{\begin{tabular}{|c|}
$\begin{array}{c}\text { Total } \\
\text { Production }\end{array}$ \\
M ODT/yr \\
\end{tabular}} & \multirow{2}{*}{$\begin{array}{c}\text { Straw/ } \\
\text { Stover } \\
\text { M ODT/yr }\end{array}$} & \multirow{2}{*}{$\begin{array}{l}\text { Sustainably } \\
\text { Removable } \\
\text { Residues } \\
\text { (SRR) }{ }^{1,2,3,4} \\
\text { M ODT/yr }\end{array}$} & \multicolumn{2}{|c|}{ Recoverable SRR ${ }^{5}$} & \multirow{2}{*}{\begin{tabular}{|c|}
$\begin{array}{c}\text { Energy Potential } \\
\text { of SRR }\end{array}$ \\
$\mathrm{EJ} / \mathrm{yr}$ \\
\end{tabular}} & \multirow{2}{*}{$\begin{array}{c}\text { Amount } \\
\text { Available }^{6} \\
\text { M ODT/yr }\end{array}$} & \multirow{2}{*}{$\frac{\text { C Content }^{7}}{\mathrm{Mt} \mathrm{C} / \mathrm{yr}}$} & \multirow{2}{*}{$\begin{array}{c}\begin{array}{c}\text { Energy } \\
\text { Potential }^{8}\end{array} \\
\text { EJ/yr }\end{array}$} \\
\hline & & & & M ODT/yr & $\mathrm{M} \mathrm{tC} / \mathrm{yr}$ & & & & \\
\hline Wheat & 20.6 & 26.7 & 21.4 & 14.97 & 6.74 & 0.241 & 7.49 & 3.37 & 0.120 \\
\hline Barley & 10.8 & 10.8 & 8.68 & 6.07 & 2.73 & 0.098 & 3.04 & 1.37 & 0.049 \\
\hline Oats & 2.7 & 2.7 & 2.15 & 1.51 & 0.68 & 0.024 & 0.75 & 0.34 & 0.012 \\
\hline Grain corn & 8.3 & 8.3 & 6.65 & 3.33 & 1.50 & 0.054 & 3.33 & 1.50 & 0.054 \\
\hline Canola & 4.9 & 4.9 & 3.94 & 2.76 & 1.24 & 0.044 & 2.76 & 1,24 & 0.044 \\
\hline Soybeans & 1.6 & 1.6 & 0.33 & 0.16 & 0.07 & 0.003 & 0.16 & 0.7 & 0.003 \\
\hline Flaxseed & 0.72 & 0.72 & 0.57 & 0.40 & 0.180 & 0.006 & 0.20 & 0.9 & 0.003 \\
\hline Rye & 0.23 & 0.23 & 0.18 & 0.13 & 0.57 & 0.002 & 0.06 & 0.29 & 0.001 \\
\hline Fodder corn & 5.2 & 0 & 0 & 0 & 0.26 & 0.009 & 0.26 & 0.12 & 0.004 \\
\hline Tame hay & 23.1 & 0 & 0 & 0 & 1.157 & 0.041 & 1.16 & 0.52 & 0.019 \\
\hline Totals & 78.27 & 56.09 & 43.89 & 29.33 & 14.62 & 0.523 & 17.79 & 8.64 & 0.309 \\
\hline
\end{tabular}

Assumes that straw to grain ratio for wheat is 1.3:1 (Levelton, 2000 Assessment of net emissions of GHG from EtOH-blended gasolines in Canada

lignocellulosic feedstocks, R-2000-2 AAFC). This ratio represents the lower end of Levelton's proposed range of 1.3 - 1.7:1.

${ }^{2}$ Assumes a straw to grain ratio of 1:1 for all other cereal grains (Helwig et al.,2002).

${ }^{3}$ Stover from grain corn production in Eastern Canada averages $2.5 \mathrm{ODT} / \mathrm{ha}$ and equals the quantity of corn grain harvested in OTDs (Helwig et al., 2002). Statistics Canada, however, shows that harvested yield averages just over 6 ODT/ha which is substantially different... it is unclear whether the Stats can figure includes fodder and grain corn, or grain corn alone. A 1:1 ratio of harvested crop to stover is assumed.

${ }^{4}$ Assumes an average sustainable removal rate of $80 \%$ (Klass, 1998; Helwig et al., 2002) for all crops except soybean. Soybean stover is not generally considered harvestable except on conservation tillage soil, which constitutes approximately $20 \%$ of soybean land, where they may be completely removed. Hence, yield of sustainably removable soybean residues is assumed to be $20 \%$ of stover.

${ }^{5}$ Assumes that not all sustainably removable residues may be retrieved, and reduces these by $30 \%$ to account for difficulties during recovery, except for grain corn and soybeans, which are reduced by $50 \%$ to account for late harvest.

Assumes that biomass will continue to be diverted to traditional uses, leaving available: $50 \%$ of cereal straws; $100 \%$ of recoverable grain corn stover canola, and soybean stover; $5 \%$ of fodder corn, and tame hay which is unused in an average year (Helwig et al., 2002). This assumption overestimates availability of straw in NB and PEI, where production is quite low, and underestimates availability in MB and SK where production is higher on average.

${ }^{7}$ Carbon content is based on an average yield for agricultural residues of $45 \% \mathrm{C}$ in OD biomass (Bioenergy Conversion Factors_.

${ }^{8}$ Assumes that $35.76 \mathrm{GJ}$ of energy may be derived from each tonne of carbon from dried biomass. This conversion factor has been tested against upper and lower heating values, both theoretical and measured, for a variety of biological feedstocks and is accurate to $5 \%$ in every case. Comparative figures from Klass, 1998, were used to derive this conversion factor.

M ODT - million oven-dry tonne; Source: BIOCAP 2003 
Table 7. Forest Residues in Canada

\begin{tabular}{|c|c|c|c|c|c|c|c|}
\hline & $\begin{array}{c}\text { Harvest } \\
\text { Roundwood }\end{array}$ & Slash & $\begin{array}{l}\text { Slash } \\
\underline{\text { Mil }}\end{array}$ & $\begin{array}{l}\text { Slash } \\
\underline{000}\end{array}$ & Roadside & Roadside & $\begin{array}{l}\text { Stump } \\
\frac{000}{N 2}\end{array}$ \\
\hline & $\underline{\text { Mil M3 }}$ & $\underline{\%}$ & $\underline{\mathrm{M} 3}$ & $\underline{\mathrm{BDt}}$ & $\%$ & $\underline{000 \mathrm{BDt}}$ & $\underline{\mathrm{BDt}}$ \\
\hline $\mathrm{BC}$ & 87.0 & $25 \%$ & 29.0 & 11,600 & $80 \%$ & 9,280 & 2,320 \\
\hline Alberta & 23.5 & $10 \%$ & 2.6 & 1,044 & $95 \%$ & 992 & 52 \\
\hline Ontario & 24.2 & $14 \%$ & 3.9 & 1,576 & $95 \%$ & 1,497 & 79 \\
\hline Quebec & 39.6 & $9 \%$ & 3.9 & 1,567 & $60 \%$ & 940 & 627 \\
\hline New Brunswick & 10.4 & $9 \%$ & 1.0 & 411 & $35 \%$ & 144 & 267 \\
\hline \multirow[t]{2}{*}{ Nova Scotia } & 5.7 & $9 \%$ & 0.6 & $\underline{225}$ & $\underline{0 \%}$ & $\underline{0}$ & $\underline{225}$ \\
\hline & 190.4 & & & $16, \overline{424}$ & $\overline{78 \%}$ & 12,853 & $3, \overline{571}$ \\
\hline
\end{tabular}

A 2004 mill residue survey of Canadian pulp mills and sawmills (BW McCloy \& Associates and Climate Change Solutions 2005) indicated annual production of bark, sawdust, and shavings of 21.2 Mt as shown in Table 8. Major producers were BC, Quebec, Ontario, and Alberta. Much of this biomass is committed to produce onsite energy, or sold to independent power producers, board and pellet manufacturers, farmers for animal bedding, and landscapers for garden beds. The study estimated that after considering domestic consumption and exports, there was a surplus of $2.7 \mathrm{Mt}$.

Table 8. Canada Surplus Mill Residues, 2004

\begin{tabular}{|lrrrr|}
\hline & \multicolumn{1}{c}{ Prod'n } & Consump. & Exports & $\begin{array}{c}\text { Surplus } \\
000\end{array}$ \\
& BDt & & & BDt \\
Province & & & & \\
BC & 6,554 & 4,389 & 350 & 1,815 \\
Alberta & 2,406 & 1,924 & 0 & 481 \\
Saskatchewan & 580 & 416 & 0 & 164 \\
Manitoba & 225 & 212 & & 13 \\
Ontario & 2,602 & 2,480 & 0.54 & 121 \\
Quebec & 6,669 & 6,400 & 169 & 100 \\
New & & & & \\
Brunswick & 1,373 & 1,223 & 150 & 0 \\
Nova Scotia & 601 & 588 & 0 & 13 \\
PEI & 24 & 23 & & 1 \\
Nfld \& Lab. & $\underline{195}$ & $\underline{166}$ & $\underline{0}$ & 30 \\
Total & 21,229 & 17,821 & 669 & 2,738 \\
\hline Source: Climate Change Solutions 2007 & & \\
BDt - Bone-Dry tonne $=$ Oven-Dry tonne & & \\
\hline
\end{tabular}

The mill residue survey also estimated that the excess bark and sawdust not used by sawmills or pulp mills, simply piled up on the mill site. This is the case in some provinces; however, in BC, Alberta, and Manitoba the approved method of residue disposal is incineration. Until recently, bark piles were considered an environmental problem, not a revenue source. Many 
piles were too contaminated, or moisture contents were considered too high for energy use. With annual residue production almost completely committed, companies are looking at these piles with renewed interest. Some are experimenting with methods to remove contaminants, or mixing wet with drier residues to produce a fuel with low average moisture content. Different companies assess the usable portion of bark piles between $50-100 \%$. The study estimated the dry biomass available from bark piles in Canada at $15.9 \mathrm{Mt}$ in 2005. Leading provinces are Ontario (6.7 Mt), Quebec (5.6 Mt), and Saskatchewan (2.9 Mt) (Climate Change Solutions 2006).

Summing together sustainably recoverable crop residues of $17.79 \mathrm{Mt}$ (Table 6), slash forest residues of $16.4 \mathrm{Mt}$ (Table 7 ) and mill residues of $21.2 \mathrm{Mt}$ (Table 8), overall farm and forest residues could sum to as much as $55 \mathrm{Mt}$ per annum. Adding in hog pile residues of $15.9 \mathrm{Mt}$, it would bring overall second generation feedstock in Canada (crop, forest, primary mill residues and hog fuel piles) to about $71 \mathrm{Mt}$ per year yielding $21.3 \mathrm{hm}^{3}$ of ethanol or $10 \mathrm{Mt}$ gasoline equivalent. This volume would replace $35 \%$ of current gasoline consumption and $23 \%$ of crude oil imports.

\section{Local Biofuels Resource Assessments}

Agriculture and Agri-Food Canada (AAFC) developed a Web-based biomass inventory tool, called Biomass Inventory Mapping and Analysis Tool (BIMAT). The tool uses GIS to illustrate the quantity and geographic distribution of agricultural and wood residues (logging, mill, and urban) at a fine spatial resolution, as illustrated in Figure 9.

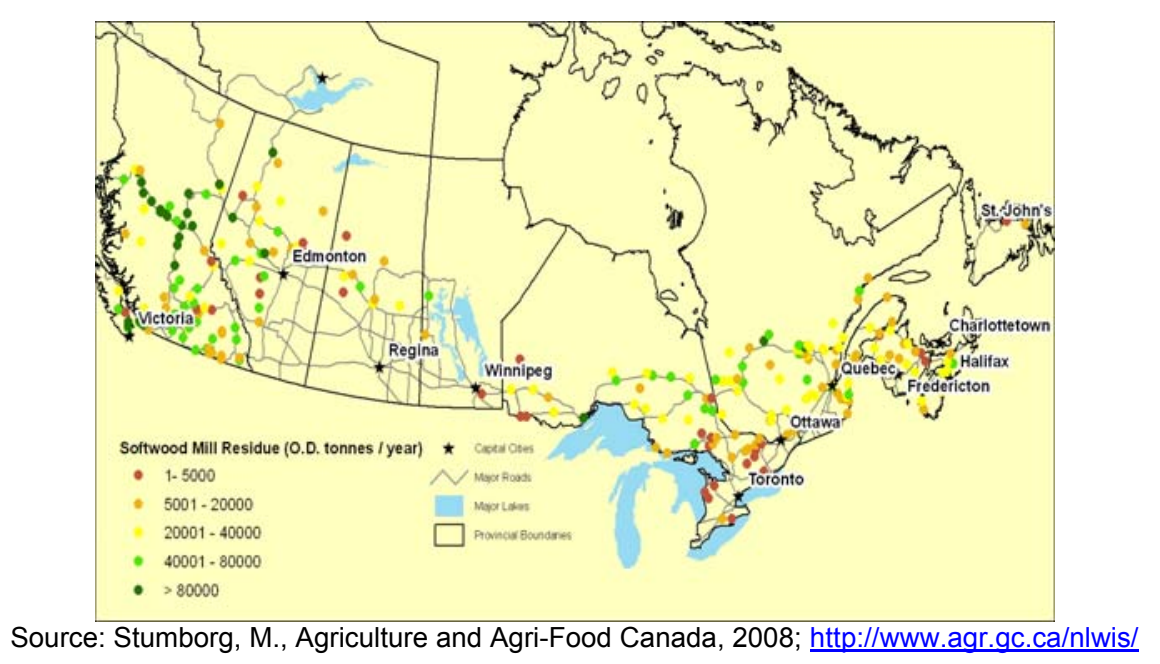

Figure 9. Softwood Mill Residues in Canada 


\section{Biomass Resource Assessment Capabilities}

Canada has extensive biomass resource assessment capabilities. These include geospatial technologies, modeling, surveying, and statistical information available through various agencies.

Geospatial technologies, as illustrated above, have been used by the AAFC to develop the biomass inventory tool (BIMAT). These technologies are also used by the Canadian Forest Service (CFS), in partnership with the Canadian Space Agency, to create products for forest inventory, forest carbon accounting, monitoring sustainable development, and landscape management. It launched a project titled Earth Observation for Sustainable Development of Forests (EOSD) to aid in developing techniques for these products. Initially, the initiative will work in partnership with the provinces, territories, universities, and industry to develop an economy-wide map of the forested land cover of Canada with the long-term goal of producing not only land cover maps, but maps of forest composition, change over time, and biomass. Overview of methods for mapping biomass resources employed by EOSD is available at http://www.pfc.forestry.ca/eosd/biomass/methods e.html. Inputs from EOSD will be an important data source in the National Forest Carbon Accounting Framework and will also be used to enhance Canada's new National Forest Inventory. EOSD data and products are available at no charge to the public and accessible through the National Forest Information System (NFIS) and SAFORAH (System of Agents for Forest Observation Research with Automation Hierarchies). The NFIS provides various geospatial products (tools and maps) that illustrate Canada's forests, vegetation, protected areas, imagery, etc. at an economy-wide and provincial/territory level (http://nfis.org/index e.shtml).

Integrated Techniques and Data Availability. CFS, which is responsible for disseminating forestry statistics, compiles Canada's forest inventory by collecting data from provincial, territorial and other forest management inventories. Provinces and territories apply a set of methods in collecting forest data: field surveys, aerial photography, GIS, and other modeling techniques as illustrated in Figure 10. The data provided by the provincial and territorial management agencies are converted to an economy-wide classification scheme, and then aggregated to the map sheet, provincial and economy-wide levels for storage, analysis and reporting. Economy-wide inventories are compiled about every five years, currently in 1981, 1986, 1991, and 2001. 


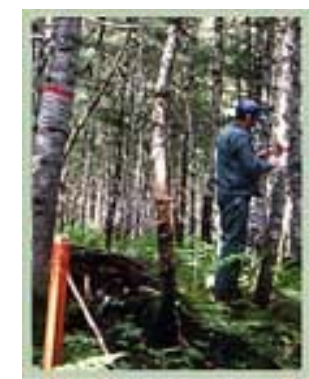

Step 1: Plot sampling

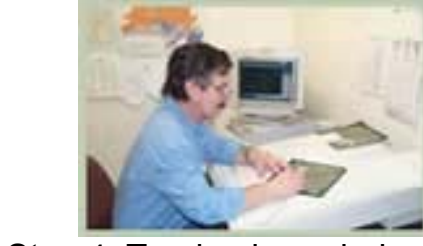

Step 4: Tracing boundaries from photo

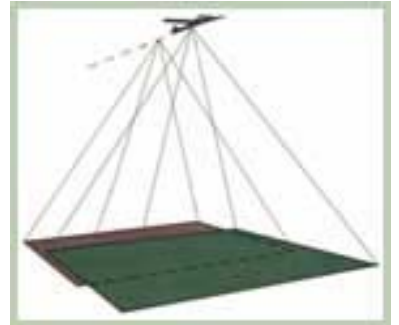

Step 2: Aerial photography

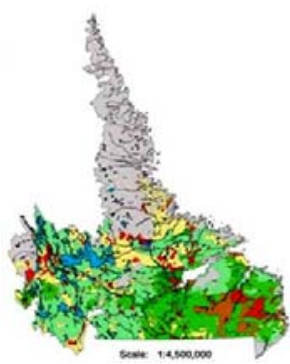

Step 5: Output from traced photo

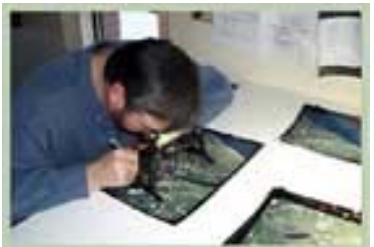

Step 3: Photo interpretation using stereoscope

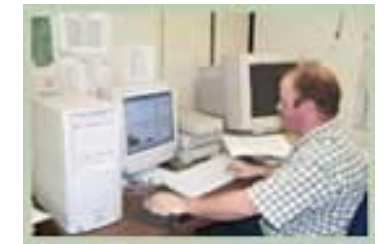

Step 6: Computer model

Source: Natural Resources, Government of Newfoundland and Labrador, Canada

Figure 10. Forest Inventory Process in Canada

Canada National Forest Inventory (CanFI) 2001 is the most recent inventory collected for Canada. The current approach to an economy-wide inventory is based on existing data making it is cost-effective. The process is well-established and accepted by the contributing agencies, and provides detailed information about Canada's forests that is consistent with forest management information. The inventory also contains location-specific information on the characteristics and quantity of the forest resource, providing mapping and spatial analysis capabilities. While this periodic compilation has many advantages, CanFI data can be up to 25 years old and collected using variable data standards. CanFI does not allow tracking of the rate and nature of changes to the resource over time, nor does it necessarily reflect the current state of the forests. It also generally lacks information on non-timber attributes and is of unknown precision. A new design for Canada's forest inventory has been developed and is being implemented to address weaknesses of CanFI. Instead of a periodic compilation of existing information from across the country, the National Forest Inventory (NFI) is a plot-based design consisting of permanent observational units located on an economy-wide grid. This new design tracks changes such as land cover, forest area, and volumes, and supports additional forest resource information. It will replace the current CanFI approach and allow comparisons with time. More information about NFI and its progress is available at http://nfi.nfis.org/ (CFS). 
Numerical and geospatial modeling has been used by the Agriculture and Agri-Food Canada (AAFC). A biomass production model estimates the amount of crop residues available after a portion of it is left on the field to meet soil protection and animal feed requirements. Further, GIS is used to illustrate the geographic distribution of these resources. Figure 11 illustrates an example - potential surplus wheat straw production in the Western Canadian prairies (Stumborg et al. 2004).

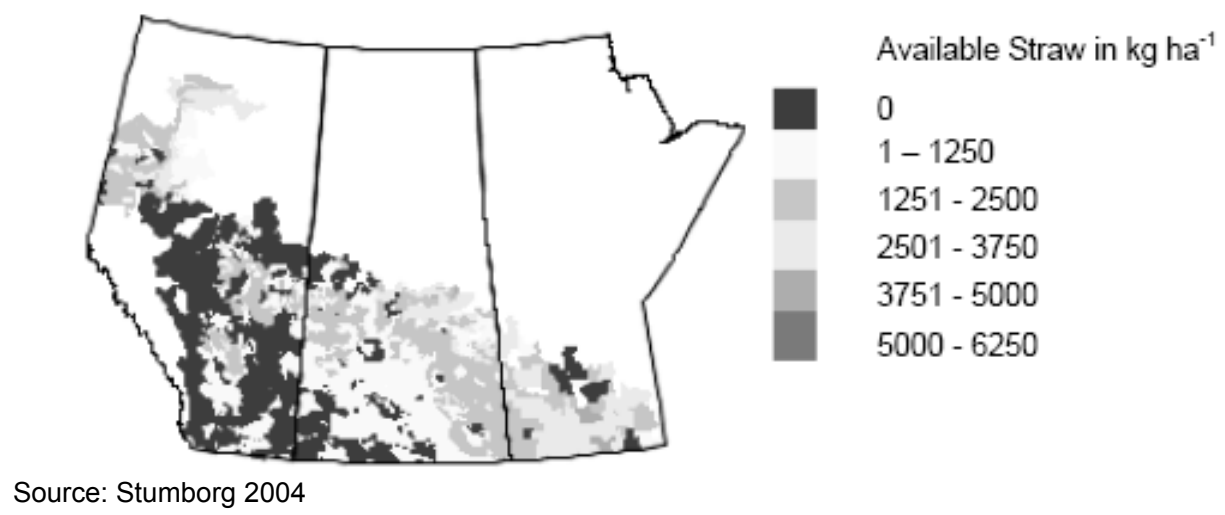

Figure 11. Areas of Potential Surplus Wheat Straw in Western Canada

The Census of Agriculture (CA), part of Canada's National Statistical Agency, is the main provider of agricultural statistics at an economy-wide, provincial/territorial, regional, divisional, and sub-divisional level. The census has been taken every five years since 1956, the most recent being developed in 2006. Data is collected using paper surveys (questionnaires) mailed to farmers. Samples are used for making agriculture estimates between census years. Provinces/Territories' Departments of Agriculture also provide agricultural statistics collected via paper and field surveys.

In addition to the agencies mentioned above, many of the leading colleges and universities in Canada with agricultural or engineering programs have the potential to contribute to biomass resource assessments efforts. Several universities, including Moncton, Sherbrooke, Guelph, Manitoba, Saskatchewan, Alberta, and BC have extensive experience in a range of agricultural disciplines. Others including McGill, Ottawa, Queen's, Toronto, McMaster, Waterloo, Saskatchewan, and Alberta have significant experience in engineering sciences that are important to the development of bio-products. Still others have strong environmental or forestry programs that could provide valuable expertise. Even universities without strengths in these 
applied disciplines may have the potential to contribute through expertise in biology, physics, chemistry, and geospatial technologies.

\section{References}

1. BIOCAP Canada Foundation, Susan M. Wood and David B. Layzell, A Canadian Biomass Inventory: Feedstocks for a Bio-based Economy, 2003, http://www.biocap.ca/images/pdfs/BIOCAP Biomass Inventory.pdf

2. Bradley, D., Climate Change Solutions, Canada Biomass-Bioenergy Report, May 2006, Ontario, Canada, http://www.climatechangesolutions.net/pdf/canada country2006.pdf

3. Bradley, D., Climate Change Solutions, Canada - Sustainable Forest Biomass Supply Chains, October 2007, Ontario, Canada, http://www.canbio.ca/documents/publications/sustainableforestsupplychainsoct192007.p df

4. BW McCloy \& Associates and Climate Change Solutions, Estimated Production, Consumption and Surplus Mill Wood Residues in Canada - 2004, A National Report for Natural Resources Canada and Forest Products Association of Canada, November 2005, http://www.climatechangesolutions.net/pdf/mill residue2005.pdf

5. Canada's National Statistical Agency, Census of Agriculture, retrieved April 2008, http://www.statcan.ca/english/agcensus2006/aboutmenu.htm

6. Canadian Agri-Food Research Council (CARC) and BIOCAP Canada, An Assessment of the Opportunities and Challenges of a Bio-Based Economy for Agriculture and Food Research in Canada, 2003, http://www.biocap.ca/files/Position Paper OCBBE.pdf

7. Canadian Canola Growers Association (CCGA), Presentation to Agri-Energy Opportunities in Manitoba, April 18, 2006

8. Canadian Forest Service, retrieved April 2008, http://cfs.nrcan.gc.ca/subsite/canfi/home

9. Department of Natural Resources, Government of Newfoundland and Labrador, retrieved in April 2008, http://www.nr.gov.nl.ca/forestry/programs/inv plan.stm

10. International Energy Agency (IEA), Country energy statistics, Oil in Canada, 2005, http://www.iea.org/Textbase/country/index.asp

11. Stumborg, M. et al., Agricultural Biomass Resources in Canada, presented at 2004 ASAE Annual Meeting, Ottawa Canada, August 2004

12. Stumborg, M. et al., Biomass Inventory and Mapping Analysis Tool (BIMAT), presentation at the Fifth APEC Biofuels Task Force meeting, Golden, Colorado, USA, October 7-9, 2008

13. U.S. Department of Agriculture (USDA), Biofuels in Canada, GAIN Report 2007, http://www.fas.usda.gov/gainfiles/200708/146292128.pdf 


\section{Chile}

\section{Economy-Wide, Provincial and Local Biofuels Resource Assessments}

\section{First-Generation Biofuels Potential}

Ethanol: Chile produces corn, wheat, and sugar beet, all of which could be used as feedstock for ethanol production. However, given the limited land available in Chile and the current need to import significant quantities of food, second-generation biofuels, particularly from forestry resources, appear to be more promising.

If the equivalent of $20 \%$ of Chile's current starch and sugar crops production could be made available for biofuel production, for example through increase in crop yields over time, it would yield about $0.26 \mathrm{~m}^{3}$ of ethanol or $0.12 \mathrm{Mt}$ gasoline equivalent. This would be enough to replace $6 \%$ of Chile's 2005 gasoline consumption and $1.2 \%$ of its 2005 crude oil imports.

Biodiesel: The Ministry of Agriculture, Office of Agrarian Studies and Policies (ODEPA), completed a study in January 2007 looking at available feedstock for biodiesel production. The project estimated that about $44,500 \mathrm{~m}^{3}(39.2 \mathrm{kt})$ of biodiesel could be produced from rapeseed and maravilla, and about 52,338 $\mathrm{m}^{3}(46.1 \mathrm{kt})$ from animal fat. This is a nationwide study with no finer geography represented, and it is based on statistical analysis of reported information.

If $20 \%$ of Chile's current vegetable oil production, as well as all waste oils and fats, could be used for biofuels, it would yield about 54,000 tonnes of biodiesel per annum. This could replace $1.7 \%$ of Chile's current diesel consumption or $0.5 \%$ of its crude oil imports.

\section{Second-Generation Biofuels Potential}

A study by the National Energy Commission (Comisión Nacional de Energía), Instituto Forestal (INFOR), and GTZ evaluated the primary mill residues at regional, provincial, and municipal levels in some cases for 2005 (CNE/INFOR/GTZ 2007). Data for this study was provided by INFOR, which collects it via surveys of sawmills. In addition to statistical analysis, the project uses GIS to map the residues available in each region, as shown in the example in Figure 12. The study concluded that about 5.5 million $\mathrm{m}^{3}$ or $3.25 \mathrm{Mt}$ of primary mill residues were available 
in Chile in 2005. This corresponds roughly to about $0.98 \mathrm{hm}^{3}$ of ethanol or $0.43 \mathrm{Mt}$ gasoline equivalent. This volume could displace $21 \%$ of Chile's current gasoline consumption and $4.2 \%$ of its crude oil imports. Crop residues have not been estimated; if included, the amount of ethanol that could be produced in Chile would be higher.

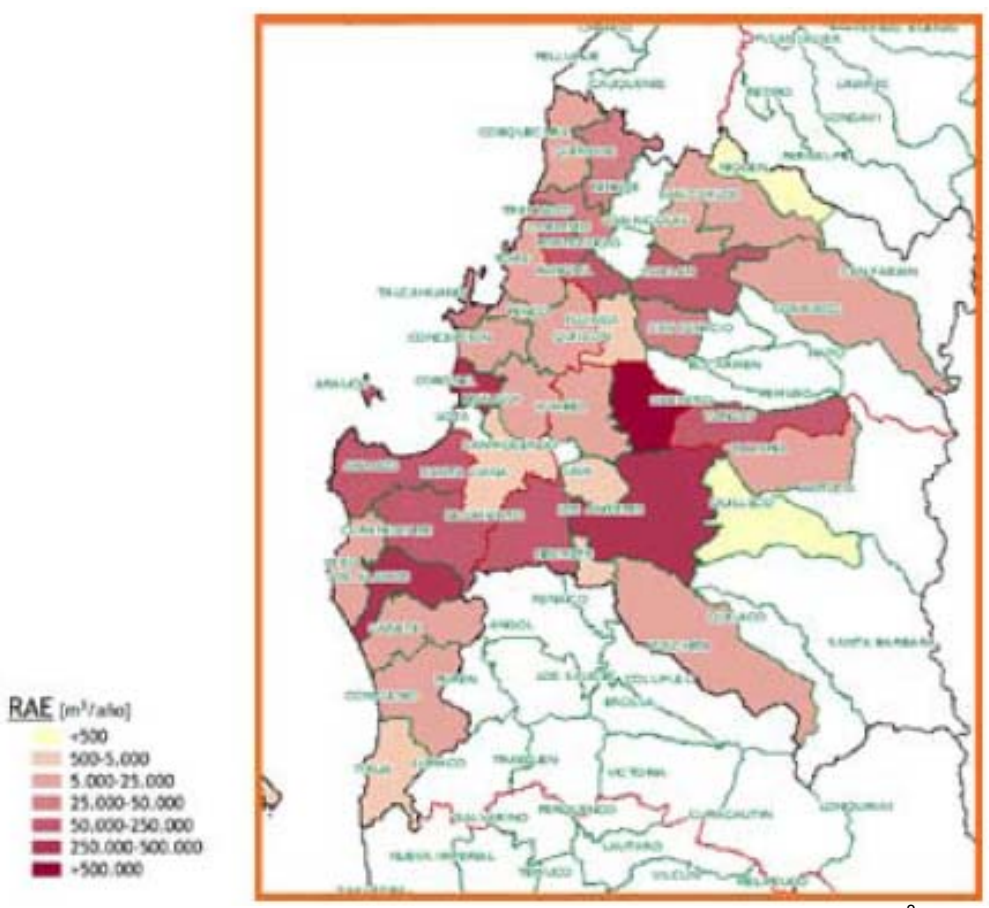

Source: CNE/INFOR/GTZ 2007; RAE - Residues Available for Energy ( $\mathrm{m}^{3} / \mathrm{year}$ )

Figure 12. Distribution of Primary Mill Residues in the Region of Bio-Bio, Chile

A study by the National Energy Commission (Comisión Nacional de Energía) and GTZ in January 2008 estimated forest biomass (harvest and pruning waste) in select regions, power generation potential, and cost of electricity. The study focused on residues generated at pine and eucalyptus plantations in the regions of O'Higgins, Bio-Bio, and Maule. It excludes residues from native forests due to their small contribution to the overall forest residue potential and lack of access in some areas. The project estimates the available tree plantation residues in 2004 and projects availability by 2017 for each region. The projections are based on 32 years of data collected for the project. The data was collected from the plantation owners and is complemented by analyses on the future availability of pine and eucalyptus carried out by the Chile Forestry Institute. The study uses a set of methods to assess biomass resources statistical analysis, simulation modeling, and GIS. Figure 13 illustrates an example of the maps generated under this project. 


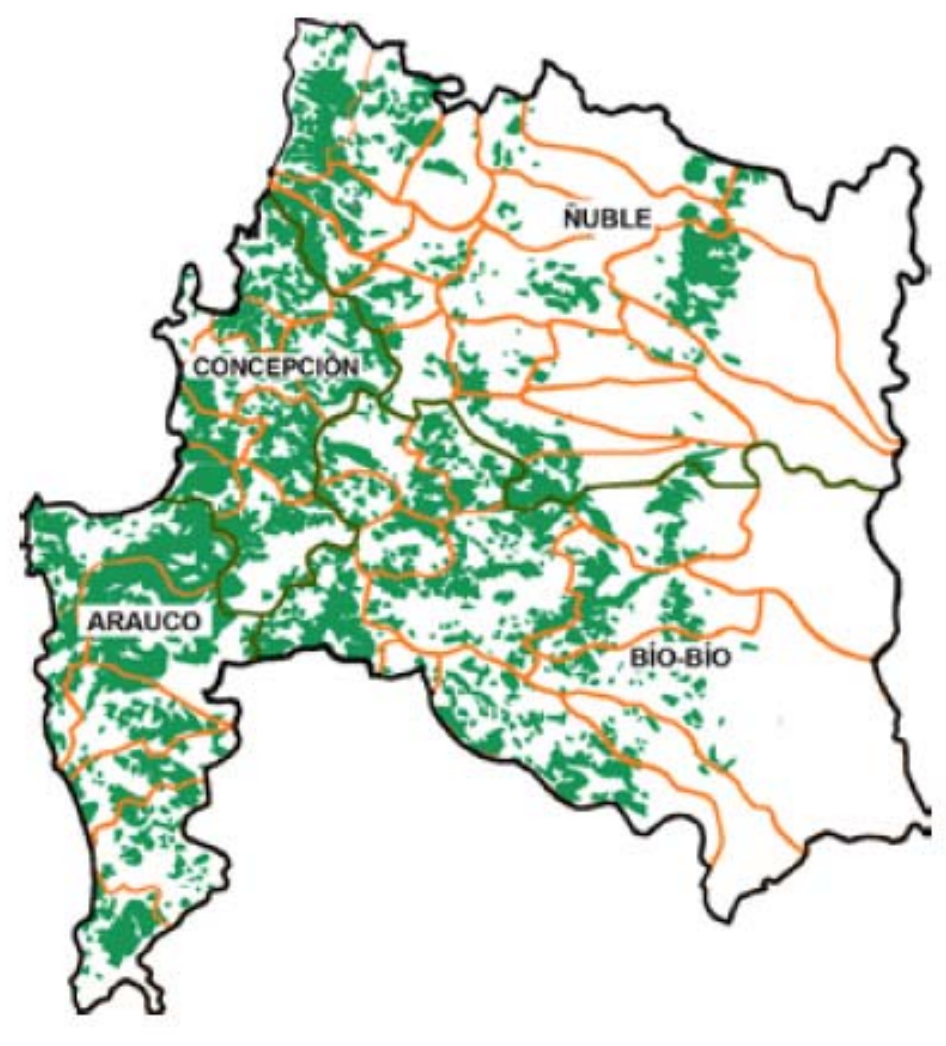

Source: CNE/GTZ 2008

Figure 13. Plantation Forests in the Region of Bio-Bio, Chile

The study concluded that residues generated at pine and eucalyptus plantations could support between 310 and $470 \mathrm{MW}$ of power generation capacity (considering residue use of $50-75 \%$, respectively), concentrated in the regions between Valparaiso and Aysen. No numbers for total volume of residues were presented. The paper only outlines the methodology used and gives an example of only one region. Thus, it was not possible to estimate the amount of ethanol that could be produced from these resources in Chile.

The government is conducting a biomass resource assessment specifically for biofuels production, and will evaluate various feedstocks. The project began in April 2008 and will be completed by early 2009. The project will estimate crop and forest residues for ethanol production, as well as investigate feedstock other than oil crops for biodiesel production. 


\section{Biomass Resource Assessment Capabilities}

It is evident from the examples above that Chile has very good biomass resource assessment capabilities. It has used various assessment methods and it maintains excellent statistics. The National Energy Commission (CNE), Department of Agriculture, and the Forestry Institute (INFOR) are leading government agencies in biomass resource assessments. These agencies provide data and expertise in their relevant field. INFOR has used geospatial technologies beyond the regular map-making services they offer. It used advanced GIS techniques to develop an interactive Web based application illustrating the primary mill residues by province, as well as the location of sawmills. Figure 14 shows the graphical interface of this application.

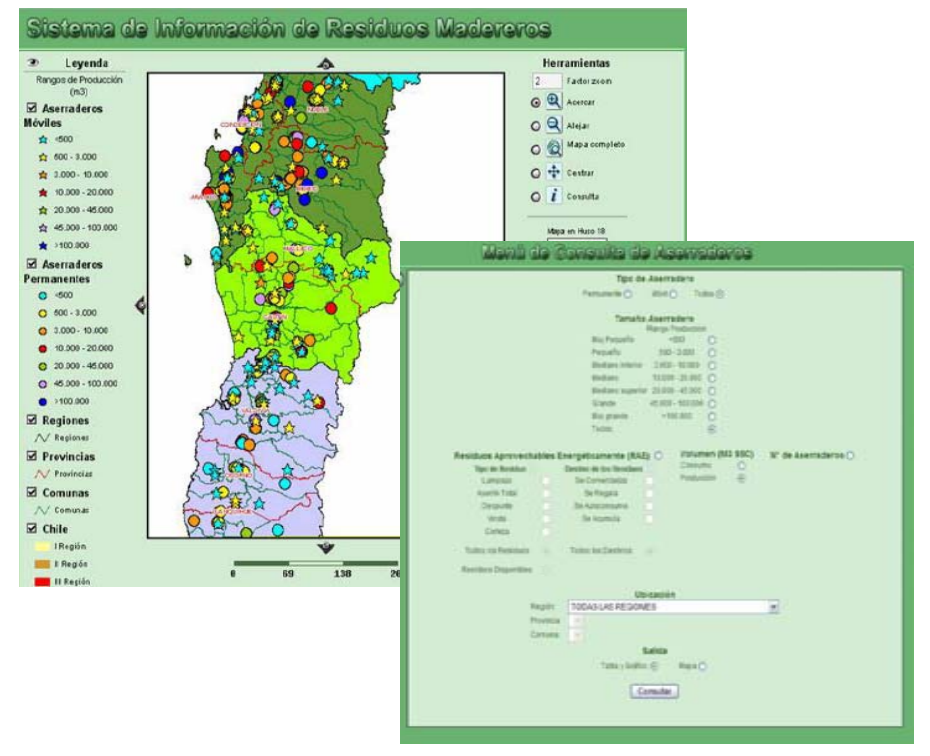

Source: INFOR 2008

Figure 14. Chile Primary Mill Residues Information System

Agricultural, forestry, and industry statistics are also provided by the National Statistics Institute (INE). INE collects information through paper or phone surveys and provides regional reports on a regular basis. Some of the universities involved in biomass research include Universidad de Concepción, Unidad de Desarrollo Tecnológico of the Universidad de Concepción, Universidad de la Frontera, and Universidad de Chile (Facultad de Agronomía and Facultad de Ciencias Forestales).

\section{References}

1. Comisión Nacional de Energía (CNE) and Deutsche Gesellschaft für Technische Zusammenarbeit (GTZ) GmbH, Potencial De Biomasa Forestal, Santiago de Chile, 
January 2008,

http://www.cne.cl/archivos bajar/guias/Estudio Potencial Biomasa Forestal.pdf

2. Comisión Nacional de Energía (CNE), Instituto Forestal (INFOR), and Deutsche Gesellschaft für Technische Zusammenarbeit (GTZ) $\mathrm{GmbH}$, Disponibilidad De Residuos Madereros, Santiago de Chile, October 2007, http://www.cne.cl/medio amb/guias.php

3. Comisión Nacional de Energía (CNE) and Deutsche Gesellschaft für Technische Zusammenarbeit (GTZ) GmbH, Potencial De Biogas, Santiago de Chile, September 2007, http://www.cne.cl/medio amb/guias.php

4. Instituto Forestal (INFOR), accessed April 2008, http://www.infor.gob.cl/

5. Instituto Nacional de Estadisticas de Chile, accessed April 2008, http://www.ine.cl

6. Ministerio De Agricultura, Oficina de Estudios y Políticas Agrarias (ODEPA), Comite Publico - Privado De Bioenergia, Informe Final, Santiago, January 2007, http://www.bcn.cl/carpeta temas/temas portada.2007-01-26.2084740943/otrosdocumentos-sobre-biocombustibles/Comite Bioenergia-Informe Final.pdf

7. Oficina de Estudios y Políticas Agrarias (ODEPA), accessed April 2008, http://www.odepa.gob.cl 


\section{China}

\section{Economy-Wide, Provincial and Local Biofuels Resource Assessments}

\section{First-Generation Biofuels Potential}

Ethanol: About $80 \%$ of the fuel ethanol in China is made from corn, the rest from wheat. However, concerns about food supply and high prices have led the industry to look at other, non-grain feedstock, such as cassava, sweet sorghum and sweet potato. China's current cassava production is estimated at $7.5 \mathrm{Mt}$ per year (USDA 2006). China's sweet potato production of about $105 \mathrm{Mt}$ accounted for $82 \%$ of global output in 2005 (100 million tones).

The Ministry of Agriculture estimated about 200 million mu (13.3 million hectares) of land is available for cassava and sweet potato cultivation in the southern provinces. The ministry has noted that if only one-fifth of this land were used for cassava and sweet potato as biofuel feedstock, it could produce about $13 \mathrm{hm}^{3}$ of fuel ethanol per year. Eighteen provinces north of the Yellow and Huaihe rivers were identified by the ministry as suitable for sweet sorghum production. The ministry has noted that if one-fifth of the saline lands in China were used for sweet sorghum production, they could yield about $19 \mathrm{hm}^{3}$ of ethanol per year. Thus counting both cassava and sweet potato on agricultural lands and sweet sorghum on marginal lands, some $32 \mathrm{hm}^{3}$ ethanol per year might be produced.

Looking more systematically at China's overall starch and sugar crop production - including cassava, corn, rice, sorghum, sugar cane, sweet potato and wheat - one-fifth of current production would amount to some $96.6 \mathrm{Mt}$. If this amount could be made available for biofuels production, for example through increase in productivity over time, roughly $32 \mathrm{hm}^{3}$ of ethanol could be produced each year. (By coincidence, this is the same figure cited in the previous paragraph for cassava, sweet potato and sweet sorghum alone; sweet sorghum is not an agricultural crop.) This would yield some $15.4 \mathrm{Mt}$ of gasoline equivalent, enough to displace $33 \%$ of China's current gasoline consumption and $12 \%$ of China's current crude oil imports.

Biodiesel: Almost all biodiesel in China is produced from used cooking oil and animal fat. About $3 \mathrm{Mt}$ of waste oil and grease are produced in China annually. A key barrier to using these resources is collection since their use is highly decentralized. 
Rape is the most widely planted oil-bearing crop in China, which has the world's highest output. The Institute of Oil Crops Research of the Chinese Academy of Agricultural Sciences announced in 2006 that it bred a new kind of rapeseed with record high oil content in a move to develop China's biodiesel industry. The new rapeseed has an oil content of $54.72 \%$, nearly $2 \%$ higher than conventional rapeseed. The institute estimated that the Yangtze River Valley, which accounts for nearly one-third of the world's rape output, could eventually produce up to $40 \mathrm{Mt}$ of biodiesel per year. That would amount to $85 \%$ of China's current annual consumption of diesel fuel. But this must be regarded as highly speculative in view of competing uses for the land in question.

Focusing on China's current vegetable oil production, including both rapeseed and soybean, one fifth of output would amount to $2.2 \mathrm{Mt}$ per annum. If this amount could be made available for biodiesel production, for example through an annual increase in productivity, and if the $3 \mathrm{Mt}$ of waste oil and grease produced each year could also be collected, there would be a potential for 5.2 Mt of biodiesel production per year. That would be enough to displace $11 \%$ of China's current diesel production and $4 \%$ of China's current crude oil imports.

\section{Second-Generation Biofuels Potential}

Agricultural and forest residues are the primary bioenergy resource generated in China, so assessments of their type, quantity, and location are most abundant. Most of the biomass resources in China are assessed at economy-wide and provincial levels. Several studies have assessed the resources at a finer level (see the example in Figure 15), using more advanced tools and methods, such as remote sensing and GIS. However, these studies are narrow in scope, assessing a particular resource at an economy-wide level or various resources in a small study area. The majority of biomass resource assessments in China are based on statistical analysis of reported information, applying product to residue coefficient. 


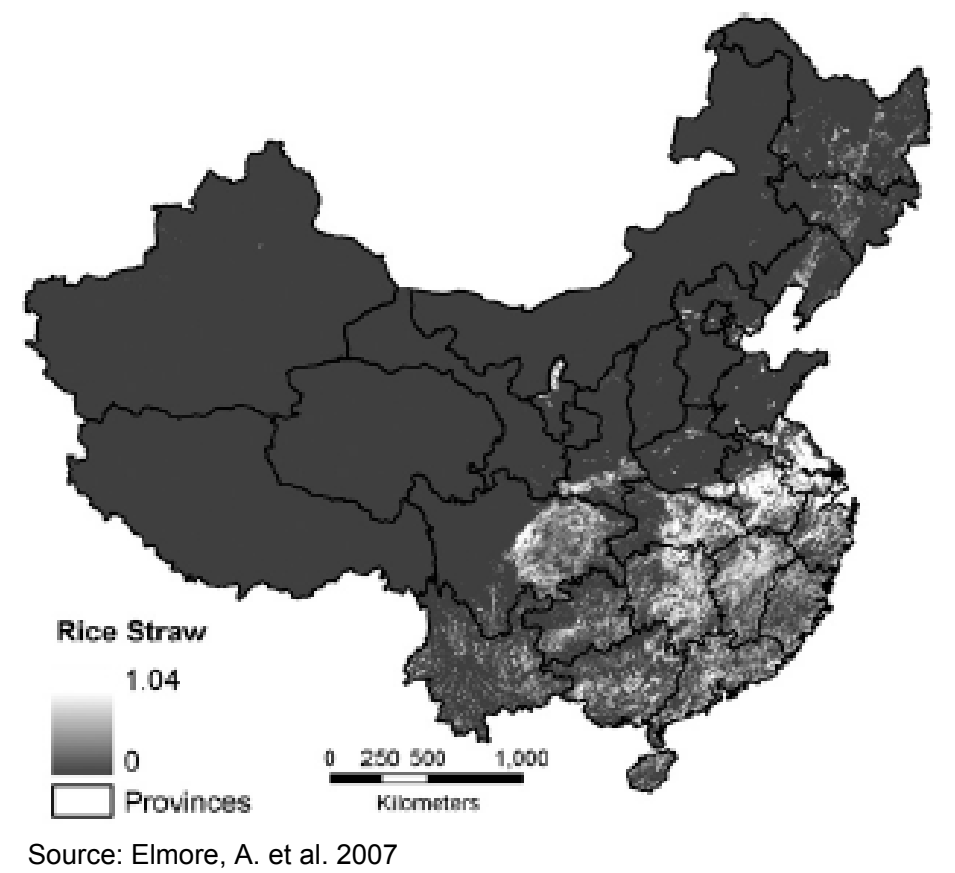

Figure 15. Rice Straw Production in 2004, Gg per $1 \mathrm{~km}$ pixel.

Ethanol: It is difficult to directly compare the different biomass resource assessments completed in China. Despite using similar methodologies to assess crop and forest residues, each study includes different feedstock, which needs to be considered when comparing results. Tables 9-10 summarize agricultural and forest residues estimated in the main biomass resource assessments completed in China. Focusing on the studies completed in 2007, which are among the most comprehensive, Liu, Jiang and others assess the potential from crop residues at 627 Mt per annum, while ERI and DTI assess the potential from forest residues at $161 \mathrm{Mt}$ per annum. Totaling these, we would arrive at a potential as high as $788 \mathrm{Mt}$ of biomass, equivalent to $236 \mathrm{hm}^{3}$ of ethanol per year. That could be sufficient to displace $247 \%$ of China's current gasoline use and $90 \%$ of China's crude oil imports.

Biodiesel: For long-term development of biodiesel, China is considering woody oil plants, such as jatropha, Chinese pistachio, and Chinese tallow tree. Research on their selection and cultivation just started in recent years. The State Forestry Administration plans to develop 12 million mu $(800,000 \mathrm{ha})$ of oil-bearing tree nuts, principally in Sichuan, Yunan, Guizhou, Chongqing, Hebei, Shaanxi, Anhui, Henan, Hubei, and Jiangxi as part of its 11th five-year plan (2006-2010). It is estimated that these trees will take more than five years to provide a sustainable feedstock supply and they could support as much as $6 \mathrm{Mt}$ of biodiesel production. 
If this should come to pass, it would amount to an extra potential of some $13 \%$ of current diesel consumption and $5 \%$ of crude oil imports.

Table 9. Summary of Agricultural Residue Assessments in China

\begin{tabular}{|l|c|l|r|}
\hline \multicolumn{1}{|c|}{ Source } & $\begin{array}{c}\text { Statistical } \\
\text { Year }\end{array}$ & \multicolumn{1}{|c|}{$\begin{array}{c}\text { Crop Residues - straw, stalks, } \\
\text { stems and leaves }\end{array}$} & $\begin{array}{c}\text { Amount } \\
\text { (Mt per } \\
\text { year) }\end{array}$ \\
\hline (Li Jingjing 1998) & 1995 & $\begin{array}{l}\text { Rice, wheat, corn, soybeans, tubers, } \\
\text { oil-bearing crops, cotton, sugar } \\
\text { cane, other miscellaneous }\end{array}$ & 605 \\
\hline (Li Junfeng 2005) & 1997 & $\begin{array}{l}\text { Rice, wheat, corn, beans, tubers, } \\
\text { sorghum, coarse grains, oil bearing, } \\
\text { cotton, sugar cane }\end{array}$ & 639 \\
\hline (Li Jingjing 2001) & 1998 & $\begin{array}{l}\text { Rice and wheat straw; rice husk; } \\
\text { bagasse }\end{array}$ & 719 \\
\hline (Liao, Yan et al. 2004) & 1999 & $\begin{array}{l}\text { Rice, wheat, corn, soybeans, } \\
\text { sorghum, cotton, hemp, rapeseed, } \\
\text { sunflower, sugar cane }\end{array}$ & 551 \\
\hline (Zeng, Ma and Ma 2007) & 2002 & $\begin{array}{l}\text { Rice, wheat, corn, beans, tubers, oil- } \\
\text { bearing crops, cotton, hemp, sugar } \\
\text { crops, other crops }\end{array}$ & 620 \\
\hline (Liu, Jiang et al. 2007) & $1995-2004$ & $\begin{array}{l}\text { Rice, wheat, corn, beans, tubers, oil- } \\
\text { bearing crops, cotton, sugar crops, } \\
\text { fiber crops, other crops }\end{array}$ & \\
\hline (ERI \& DTI 2007) & 2006 & $\begin{array}{l}\text { Rice, wheat, corn, legume, potato, } \\
\text { cotton, oil-bearing crops }\end{array}$ & 627 \\
\hline
\end{tabular}

Table 10. Summary of Forest Biomass Resource Assessments in China

\begin{tabular}{|l|r|l|r|}
\hline \multicolumn{1}{|c|}{ Source } & $\begin{array}{c}\text { Statistical } \\
\text { Year }\end{array}$ & \multicolumn{1}{|c|}{ Forest Residues } & $\begin{array}{c}\text { Amount } \\
\text { (Mt per } \\
\text { year) }\end{array}$ \\
\hline (Li Jingjing 1998) & 1995 & $\begin{array}{l}\text { Residues from felling areas and } \\
\text { wood processing factories }\end{array}$ & 26 \\
\hline (Li Jingjing 2001) & 1998 & $\begin{array}{l}\text { Mainly logging residues and forest } \\
\text { maintenance operations. A small } \\
\text { contribution from fuelwood } \\
\text { plantations is also included }\end{array}$ & 110 \\
\hline (Liao, Yan et al. 2004) & 1999 & $\begin{array}{l}\text { Forest residues, shrubbery and } \\
\text { orchards* }\end{array}$ & 104 \\
\hline & & $\begin{array}{l}\text { Residues from fuelwood forests, } \\
\text { felling remainders, processing } \\
\text { remainders, shrubbery, and other } \\
\text { forests (economic forests and } \\
\text { bamboo groves) }\end{array}$ & 161 \\
\hline (ERI \& DTI 2007) & 2006 & \\
\hline
\end{tabular}

* The study includes residues from the following forest types: Protection forests: forests, trees and bushes mainly aimed at protection, inclusive of water source storage forests, forests for water and soil conservation, wind protection and sand bind forests, forests for farmland and grassland protection, river bank protective belts and road protection belts; Timber stands: forests and trees mainly aimed at timber production, including bamboo groves mainly aimed at bamboo production; Economic forests: trees mainly aimed at the production of fruits, edible oils, soft drinks and ingredients, industrial raw materials, and medicinal materials; Firewood forests: trees mainly aimed at the production of fuels; Forests for special uses: forests and trees mainly aimed at national defense, environmental protection and scientific experiments, inclusive of national defense forests, experimental forests, parent stands, environmental protection forests, scenic beauty forests, trees for sites of historical interests and the forests of natural protection areas. 


\section{Biomass Resource Assessment Capabilities}

In China, biomass resource assessments have been completed by university researchers and the Energy Research Institute (ERI), a department of the National Development and Reform Commission (NDRC). In some cases, these assessments were developed with technical support from foreign agencies and institutions predominately in the United States, Japan, Canada, and Australia.

University Expertise. Any university with agricultural and forestry departments, or chemical and engineering departments with biomass orientation, would be able to provide knowledge and expertise in the biomass field and contribute to resource assessment efforts. Likewise, geography, GIS, RS, and informational technology departments would offer expertise in geospatial science. Often, agricultural and forestry programs offer geospatial studies as part of the curriculum to provide awareness of GIS and RS as useful research tools. The survey identified two institutions that have been heavily involved in biomass resource assessment activities in the past. These are the Chinese Academy of Forestry (CAF) and the Chinese Academy of Sciences (CAS). CAF's Research Institute of Forest Resource Information Techniques is one of China's leading scientific institutions, especially in the field of GIS, RS, and theoretical modeling in forest resources management - including the development of growth models of forest stands and quantitative evaluation techniques of forest-management activities. Two other research institutes - the Research Institute of Forestry (RIF) and the Forest Ecology, Environment and Protection (RIFEEP) - provide research related to plant science, forest management, ecology, protection, monitoring, etc. More information on CAF and its research institutes is available at http://www.forestry.ac.cn/newcaf/home.cfm. CAS's institutes and laboratories involved in biomass resource assessment include: Institute of Geographical Sciences and Natural Resources Research; Laboratory of Biomass Energy - Guangzhou Institute of Energy Conversion; Laboratory of Quantitative Vegetation Ecology - Institute of Botany; and Laboratory of Remote Sensing Information Science - Institute of Remote Sensing Application. There are other institutions that have been involved in biomass resource assessments, which are listed below:

- School of Geography and Planning, Sun Yat-sen University, Guangzhou

- Guangzhou Institute of Geography, Guangzhou

- College of Forest Resources and Environment, Nanjing Forestry University, Nanjing

- Department of Resource and Environmental Science, Chongqing University, Chongqing 
- College of Resource and Environment Engineering, East China University of Science and Technology, Shanghai

- Agronomy Department, Shandong Agricultural University, Tai'an, Shandong Province

- Shandong Academy of Sciences, Ji'nan, Shandong Province

- Department of Ecology, College of Environmental Sciences, and Key Laboratory for Earth Surface Processes of the Ministry of Education, Peking University, Beijing

- Ecology Program, Northeast Forestry University, Harbin, Heilongjiang

- College of Life Science, Beijing Normal University, Beijing

- Thermal Energy Research Institute, Tianjin University, Tianjin

- International Institute for Earth System Science, Nanjing University, Nanjing

- College of Resources and Environmental Science, China Agricultural University, Beijing

- College of Engineering, Nanjing Agriculture University, Nanjing

- Institute of Agricultural Remote Sensing \& Information Application, Zhejiang University, Hangzhou

Geospatial technologies - RS and GIS - have not been widely used for resource assessments in China, although many universities appear to have the capabilities. Remote sensing and GIS have been used to estimate crop residues, net primary productivity (NPP) ${ }^{4}$ of forests, forest density, and change in forest density.

Geospatial techniques will be used in China's second economy-wide land survey to obtain upto-date and accurate land data for policy making. The survey will be completed by October 2009. China conducted its first economy-wide land survey in 1996 but, given the substantial changes that have taken place in urban and rural areas, the data collected 11 years ago are now out of date. The purpose of the 1996 nationwide survey was to gather systematic countylevel data on the types, area, and location of land use as well as information on land ownership. The survey was primarily based on the reading, verification, classification, and measurement of different land use from the most recent aerial photos, satellite images, and maps available. The second land use survey will use advanced geospatial technologies and GIS. It will build an electronic database for the survey findings and determine statistical and monitoring methods to track changes in land resources and a system to update the information on a regular basis. The

\footnotetext{
${ }^{4}$ Net primary productivity (NPP) is defined as the net flux of carbon from the atmosphere into green plants per unit time.
} 
survey will also look at the situation of basic farmland that is widely seen as critical to the country's food security.

Modeling. As mentioned earlier, most of the completed resource assessments in China are based on statistical analysis of reported information. To assess lignocellulosic biomass availability, these analyses apply crop-to-residue ratios and forest-residue generation per land unit to production data reported at economy-wide or provincial level in statistical yearbooks. Advanced modeling techniques - linear and simulation modeling - have not been used as often in resource assessments. Models' input data are based on direct field measurements at sample plots or information obtained from paper surveys.

Data Availability. Agricultural and forestry data is readily available in China to support biomass resource assessments. The Ministry of Agriculture (MOA) and the State Forestry Administration (SFA), formerly the Ministry of Forestry, along with the National Bureau of Statistics (NBS) are the major statistical agencies in China.

MOA is responsible for conducting the nationwide sampling survey. Under this scheme, the province selects counties, the county selects villages and the village selects plots or farm households. The sample counties account for $20 \%$ in one province and for the small province no fewer than seven counties must be selected. The sample villages account for $3-5 \%$ in one county and the sample households account for $20 \%$. It generally selects $7-10$ sample plots in the north and 15 plots in the south. More information on the agricultural survey, structure, and process is available from FAO at http://faorap-apcas.org/rdes/PPT/china metadata.pdf.

MOA and NBS work together to disseminate agricultural statistics. These include area planted; average yield; production of grains, cotton, oil-bearing crops, and sugar crops; as well as information on forest products and animal husbandry by province for 1996-2005. NBS provides this information via its Web site in both Chinese and English at http://www.stats.gov.cn/english/statisticaldata/yearlydata/. MOA publishes China's Agricultural Statistics Report in Chinese annually.

China's State Forestry Administration (SFA) has been conducting a National Forest Inventory (NFI) every five years since 1973: first (1973-1976), second (1977-1981), third (1984-1988), fourth (1989-1993), fifth (1994-1998), sixth (1999-2003), and seventh (in progress). These NFIs apply different methods and techniques in collecting forest resources information. During 
the first NFI, most provinces used a random sampling method, which made it difficult for comparison of a field over time. Thus, a network of permanent sample plots was developed during the second NFI. During the third NFI, computers were first introduced to forest inventory, which significantly improved the efficiency of data processing and analysis. Remote sensing sample plots (measured from aerial and satellite imagery) were used in the fourth NFI to complement ground sample plots, and GIS and GPS were widely used during the fifth NFI. Today, the NFI uses a combination of field survey and geospatial techniques to collect forest resources information. SFA uses paper surveys (at the township level) to collect information on forestry products, such as non-wood forest products, timber harvested by villagers, industrial logging, wood processing and forest chemical products. Information on forest resources is released in China Forestry Yearbook (first published in 1986) and China Forestry Resources (first published in 2005), providing data from the sixth NFI. Publications on forestry products include China Forestry Statistics 1949-1987, China Forestry Statistics (published annually since 1988, this publication has the most extensive forestry data), China Agricultural Yearbook (published in both Chinese and English), and the Rural Statistical Yearbook of China. More information of the forestry statistics, collection methodologies, and dissemination is available from the Center for International Forestry Research (CIFOR) at http://www.cifor.cgiar.org/publications/pdf files/WPapers/WP36Dachang.pdf.

Overall Biomass Resource Assessment Capabilities. It is evident from the summary above that China has the capabilities to achieve a finer than province level biomass resource assessment. Geospatial technologies have been used in the forestry field and by academia for many years. Applying these techniques to the agricultural sector would ensure an efficient way of evaluating and monitoring crop production. Close coordination of activities between the government and academia, as well as sharing knowledge and expertise with relevant entities abroad, would provide a successful outcome of future biomass resource assessment efforts.

\section{References}

1. China Daily, "China to launch 2nd national land survey in July", June 22, 2007,

2. http://www.chinadaily.com.cn/bizchina/2007-06/22/content_900401.htm

3. Center for International Forestry Research (CIFOR), The assessment and monitoring of forest resources and forestry product statistics in China, 2006, Jakarta, Indonesia, http://www.cifor.cgiar.org/publications/pdf_files/WPapers/WP36Dachang.pdf

4. Dai, L. (1998). "The development and prospective of bioenergy technology in China." Biomass and Bioenergy 15(2): 181-186. 
5. Dong, S., K. W. Tong, et al. (2001). "Municipal solid waste management in China: using commercial management to solve a growing problem." Utilities Policy 10(1): 7-11.

6. Elmore, A. J., X. Shi, et al. (2008). "Spatial distribution of agricultural residue from rice for potential biofuel production in China." Biomass and Bioenergy 32 (1): 22-27.

7. Energy Research Institute (ERI) and Danish Technological Institute (DTI). (2007) "Assessment report on biomass resource". In Press.

8. Fang, S., J. Xue, et al. (2007). "Biomass production and carbon sequestration potential in poplar plantations with different management patterns." Journal of Environmental Management 85 (3): 672-679.

9. FAO, Regional Data Exchange System (RDES), Metadata for national agricultural statistics - China, 2006, accessed March 2008,

10. http://faorap-apcas.org/rdes/PPT/china_metadata.pdf

11. He, K., H. Huo, et al. (2005). "Oil consumption and CO2 emissions in China's road transport: current status, future trends, and policy implications." Energy Policy 33(12): 1499-1507.

12. International Energy Agency (IEA), Country energy statistics, Oil in China, 2005. http://www.iea.org/Textbase/country/index.asp

13. Jiang, H., M. J. Apps, et al. (2002). "Modelling the influence of harvesting on Chinese boreal forest carbon dynamics." Forest Ecology and Management 169(1-2): 65-82.

14. Jiang, H., M. J. Apps, et al. (1999). "Modelling the spatial pattern of net primary productivity in Chinese forests." Ecological Modelling 122(3): 275-288.

15. Jiang, H., C. Peng, et al. (1999). "Modelling the net primary productivity of temperate forest ecosystems in China with a GAP model." Ecological Modelling 122(3): 225-238.

16. Leng, R., C. Wang, et al. "Life cycle inventory and energy analysis of cassava-based Fuel ethanol in China." Journal of Cleaner Production In Press, Corrected Proof.

17. Li, J. and R. Hu (2003). "Sustainable biomass production for energy in China." Biomass and Bioenergy 25(5): 483-499.

18. Li Jingjing, et al. (1998). Assessment of Biomass Resource Availability in China. Beijing, China Environmental Science Press.

19. Li Jingjing, Z. X., Pat DeLaquil and Eric Larson (2001). "Biomass energy in China and its potential." Energy for Sustainable Development V(4): 66-80.

20. Li Junfeng, H. R., Song Yanqin, Shi Jingli, S.C. Bhattacharya, and P. Abdul Salam (2005). "Assessment of sustainable energy potential of non-plantation biomass resources in China." Biomass and Bioenergy 29(3): 167-177.

21. Liao, C., C. Wu, et al. (2004). "Chemical elemental characteristics of biomass fuels in China." Biomass and Bioenergy 27(2): 119-130.

22. Liao, C., Y. Yan, et al. (2004). "Study on the distribution and quantity of biomass residues resource in China." Biomass and Bioenergy 27(2): 111-117.

23. Lin, G. C. S. and S. P. S. Ho (2003). "China's land resources and land-use change: insights from the 1996 land survey." Land Use Policy 20(2): 87-107.

24. Liu, H., G. M. Jiang, et al. (2007). "Distribution, utilization structure and potential of biomass resources in rural China: With special references of crop residues." Renewable and Sustainable Energy Reviews 12 (5): 1402-1418.

25. Liu Zhiqiang et al. (2006) "Status and prospect of the application of municipal solid waste incineration in China". Applied Thermal Engineering 26 1193-1197

26. Luo, T., W. Li, et al. (2002). "Estimated Biomass and Productivity of Natural Vegetation on the Tibetan Plateau." Ecological Applications 12(4): 980-997.

27. Ni, J. (2004). "Forest productivity of the Altay and Tianshan Mountains in the dryland, northwestern China." Forest Ecology and Management 202(1-3): 13-22. 
28. Tan, K., S. Piao, et al. (2007). "Satellite-based estimation of biomass carbon stocks for northeast China's forests between 1982 and 1999." Forest Ecology and Management 240(1-3): 114-121.

29. U.S. Department of Agriculture, Foreign Agricultural Service, Strict Government Control Characterizes Chinese Biofuel Development, September 2006, http://www.fas.usda.gov/info/fasworldwide/2006/09-2006/ChinaBiofuels.pdf

30. Wang, C. (2006). "Biomass allometric equations for 10 co-occurring tree species in Chinese temperate forests." Forest Ecology and Management 222(1-3): 9-16.

31. Wang, C., S. Yu, et al. (2005). Life Cycle Assessment on Biomass-based Ethanol Fuel in China. Shanghai, Institute of Life Quality via Mechanical Engineering, Shanghai Jiaotong University: 46.

32. Wang, J., S. Shuai, et al. (2007). "Application and Development of Biomass Fuels for Transportation in China." Tsinghua Science \& Technology 12(2): 223-230.

33. Wang, S., C. Zhou, et al. (2002). "Carbon storage in northeast China as estimated from vegetation and soil inventories." Environmental Pollution 116(Supplement 1): S157S165.

34. Wu, C. Z., H. Huang, et al. (2002). "An economic analysis of biomass gasification and power generation in China." Bioresource Technology 83(1): 65-70.

35. Xiong, S., Q.-G. Zhang, et al. (2008) "Influence of harvest time on fuel characteristics of five potential energy crops in northern China." Bioresource Technology 99(3):479-85

36. Yan, X., T. Ohara, et al. (2006). "Bottom-up estimate of biomass burning in mainland China." Atmospheric Environment 40(27): 5262-5273.

37. Yuan, H., L. a. Wang, et al. (2006). "Urban solid waste management in Chongqing: Challenges and opportunities." Waste Management 26(9): 1052- 1062.

38. Zeng, X., Y. Ma, et al. (2007). "Utilization of straw in biomass energy in China." Renewable and Sustainable Energy Reviews 11(5): 976-987.

39. Zhang, X.-Q. and D. Xu (2003). "Potential carbon sequestration in China's forests." Environmental Science \& Policy 6(5): 421-432.

40. Zhao, M. and G.-S. Zhou (2005). "Estimation of biomass and net primary productivity of major planted forests in China based on forest inventory data." Forest Ecology and Management 207(3): 295-313.

41. Zheng, G., J. M. Chen, et al. (2007) "Combining remote sensing imagery and forest age inventory for biomass mapping." Journal of Environmental Management 85 (3): 616-623.

42. Zhou, G., Y. Wang, et al. (2002). "Estimating biomass and net primary production from forest inventory data: a case study of China's Larix forests." Forest Ecology and Management 169(1-2): 149-157. 


\section{Hong Kong, China}

Hong Kong is a small metropolitan city with very high population and vehicle density. Rapid urbanization in the past two decades had led to serious air pollution problems. To cope with the situation, the government of Hong Kong has adopted many programs and measures focused on improving the fuel quality and efficiency, one of which is blending petro-diesel with biodiesel.

Hong Kong has no natural resources and the only biodiesel feedstock available domestically is waste oil - recycled and grease trap oils from restaurants and food processing industries. According to Dynamic Progress Ltd., the only licensed biodiesel manufacturer in Hong Kong, there were about 25,000 liters of used cooking oil produced and collected per day in 2007. Of that, about 3,500 liters per day are recycled domestically and the rest (about 21,500 liters per day) are exported. Trap grease collected and disposed of at landfills is approximately 8,000 liters per day. If the export portion of used cooking oil and trap grease are used for biodiesel production domestically, it would yield more than 10 million liters (9,000 tonnes) of biodiesel per year (assuming waste oil generation stays the same). Diesel consumption in Hong Kong was about 1,500 million liters (1.3 Mt) in 2005 (IEA 2005), so biodiesel would displace less than $1 \%$ of petro-diesel consumption.

\section{References}

1. International Energy Agency (IEA), Country energy statistics, Oil in Hong Kong, 2005. http://www.iea.org/Textbase/country/index.asp

2. Leung, D.Y.C., (2001) "Development of a clean biodiesel fuel in Hong Kong using recycled oil", Water, Air, \& Soil Pollution journal, 130 (1-4), 277-282

3. Personal communication with Steve Choi, Executive Director of Dynamic Progress, Ltd., May 2008 


\section{Indonesia}

\section{Economy-Wide Biofuels Resource Assessments}

\section{First-Generation Biofuels Potential}

Ethanol: Currently, fuel ethanol in Indonesia is produced mainly from sugar cane molasses. The economy is among the top 10 sugar cane producers in the world with about $30 \mathrm{Mt}$ per year. Another feedstock considered for ethanol production in Indonesia is cassava with annual production of about $17 \mathrm{Mt}$. Indonesia plans to expand current production of sugar cane and cassava and dedicate more than 1.5 million ha to growing these crops for biofuels production in the next few years. The Ministry of Energy and Mineral Resources released maps illustrating areas suitable for growing these crops, developed to support decision making and planning activities (Figures 16 and 17).

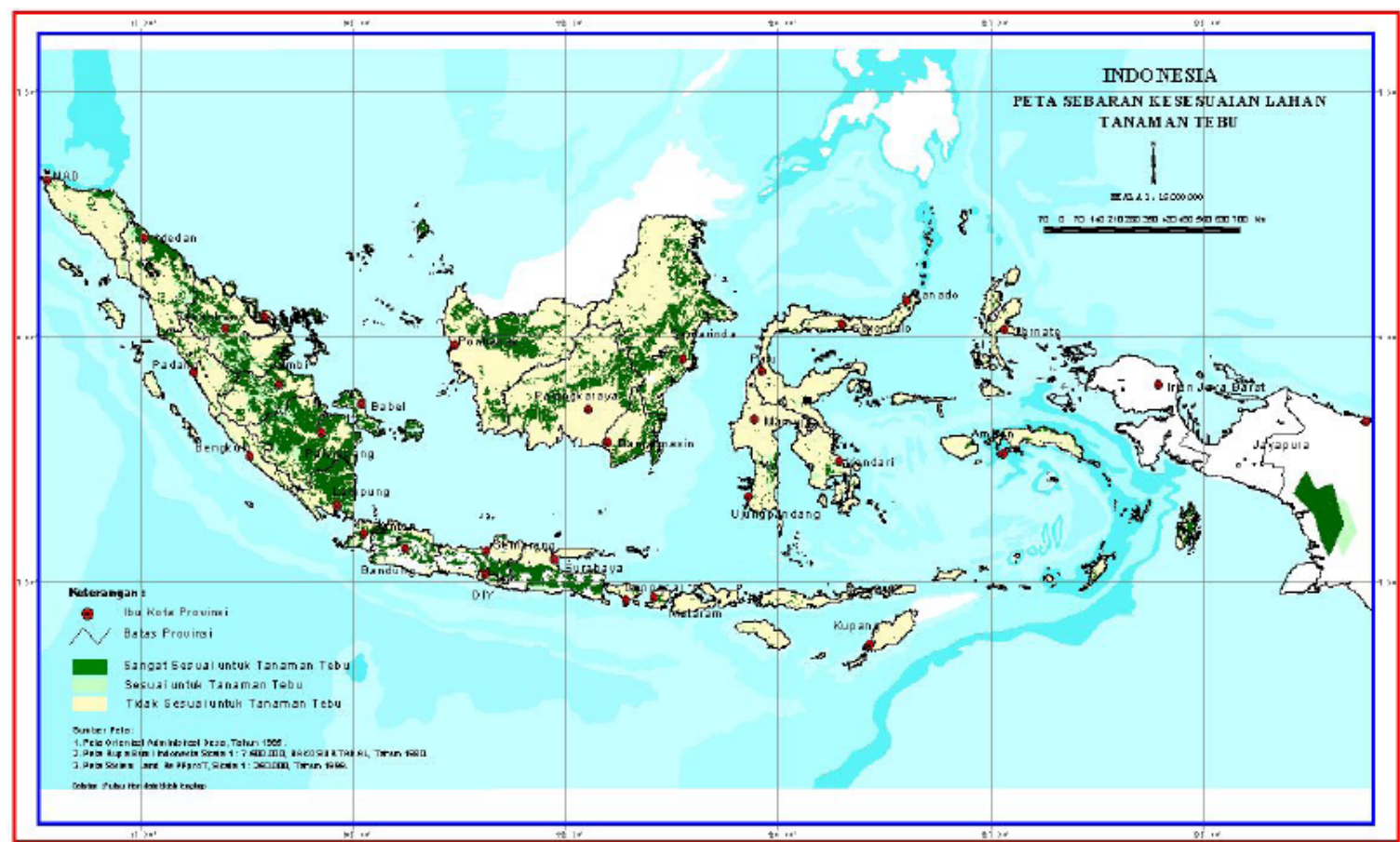

Source: Legowo 2007; Total land suitable for sugar cane production is 500,000 ha; Dark green - very suitable land; light green - suitable land; yellow - not suitable land.

Figure 16. Land Suitable for Sugar cane in Indonesia 


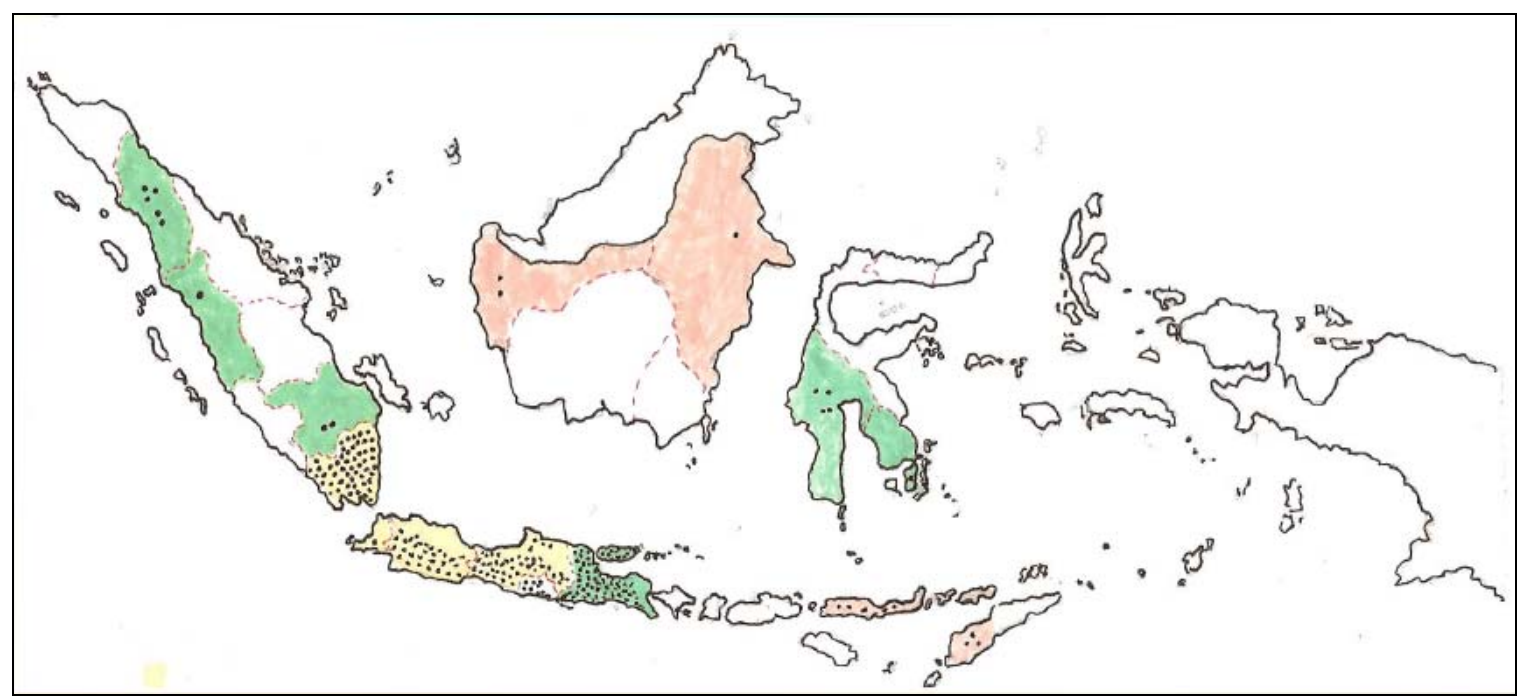

Source: Legowo 2007; Suitable land: white (less than 75 ha), yellow (75-200 ha), green (200-400 ha), red (400-1.800 ha). Each dot represents production potential of 100 tonnes.

Figure 17. Land Suitable for Cassava in Indonesia

If the equivalent of $20 \%$ of Indonesia's current starch and sugar crops production could be made available for biofuel production, for example through increase in crop yields over time, it would yield about $6.7 \mathrm{hm}^{3}$ of ethanol or $3.2 \mathrm{Mt}$ gasoline equivalent. Such a volume would replace about $25 \%$ of Indonesia's current gasoline consumption and $16 \%$ of its current crude oil imports.

Biodiesel: The main biodiesel feedstock in Indonesia is palm oil, due to the well-established industry and potential for increase in production. Indonesia surpassed Malaysia in palm oil production in 2007 and is now the world leader. Together, Malaysia and Indonesia provide $90 \%$ of the world's palm oil. Indonesia produced 17.4 Mt in 2007; up from 15.9 Mt in 2006 (about 12 Mt were exported). There are about 6 million ha of oil-palm plantations with another 3 million ha suitable for this crop (Figure 18). Another potential biodiesel feedstock in Indonesia is coconut oil, of which production amounted to nearly $0.9 \mathrm{Mt}$ and exports to about $0.5 \mathrm{Mt}$ in 2006 .

If the equivalent of $20 \%$ of Indonesia's current vegetable oil production were available for biofuels, it would yield about 3.4 Mt of biodiesel. This could replace $34 \%$ of the economy's current diesel consumption and $16 \%$ of its current crude oil imports. 


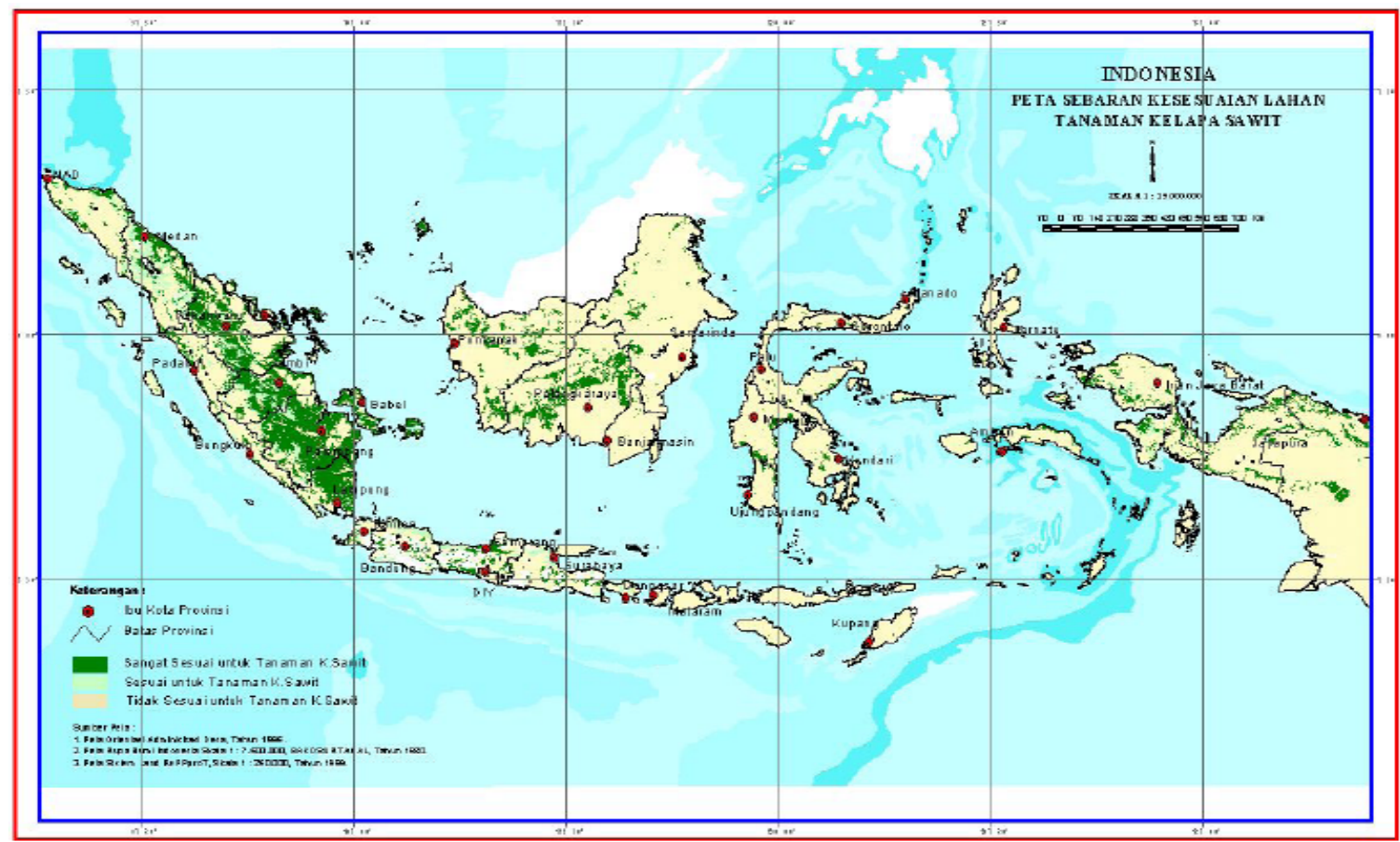

Source: Legowo 2007; Additional land suitable for oil-palm production is 3 million ha; Dark green - very suitable land; light green - suitable land; yellow - not suitable land.

Figure 18. Land Suitable for Oil-Palm in Indonesia

\section{Second-Generation Biofuels Potential}

Ethanol: An economy-wide biomass resource assessment was completed by the Agency for the Assessment and Application of Technology (AAAT), which appears to be the main government entity involved in this type of analysis. Table 11 summarizes the most recent statistics on lignocellulosic biomass provided by AAAT. This information was further used to estimate the electric potential of these resources by province (Privanto 2007).

As shown in Table 11, second generation feedstock (excluding Palm Oil Mill Effluent or POME) amounts to about $74 \mathrm{Mt}$ per year. This would yield $22 \mathrm{hm}^{3}$ of ethanol or $10.7 \mathrm{Mt}$ gasoline equivalent per annum. Such a volume would displace $83 \%$ of Indonesia's current gasoline consumption and $51 \%$ of its current crude oil imports. 
Table 11. Agricultural and Wood Residues in Indonesia

\begin{tabular}{|l|r|}
\hline Biomass Residues & Quantity (million tonnes/yr) \\
\hline Sugar industry & 8.5 \\
\hline Baggase & 1.3 \\
\hline Leaf cane & 3.5 \\
\hline Palm Oil Industry & 6.7 \\
\hline Shell & 12.9 \\
\hline Fibre & 31.0 \\
\hline Empty fruit bunch & \\
\hline Palm Oil Mill Effluent & 2.8 \\
\hline Rubber & \\
\hline Rubber wood & 3.0 \\
\hline Coconut & 6.7 \\
\hline Shell & \\
\hline Fibre & 13.5 \\
\hline Paddy & 7.3 \\
\hline Rice husk & 8.3 \\
\hline Cassava waste & 105.5 \\
\hline Wood waste & \\
\hline Total &
\end{tabular}

Source: Febijanto 2007; Priyanto 2007

Biodiesel: A potential biodiesel feedstock considered in Indonesia is jatropha. Jatropha is still in the very early stage of development and efforts appear to be focused on small scale plantations. Figure 19 illustrates areas suitable for growing jatropha in Indonesia.

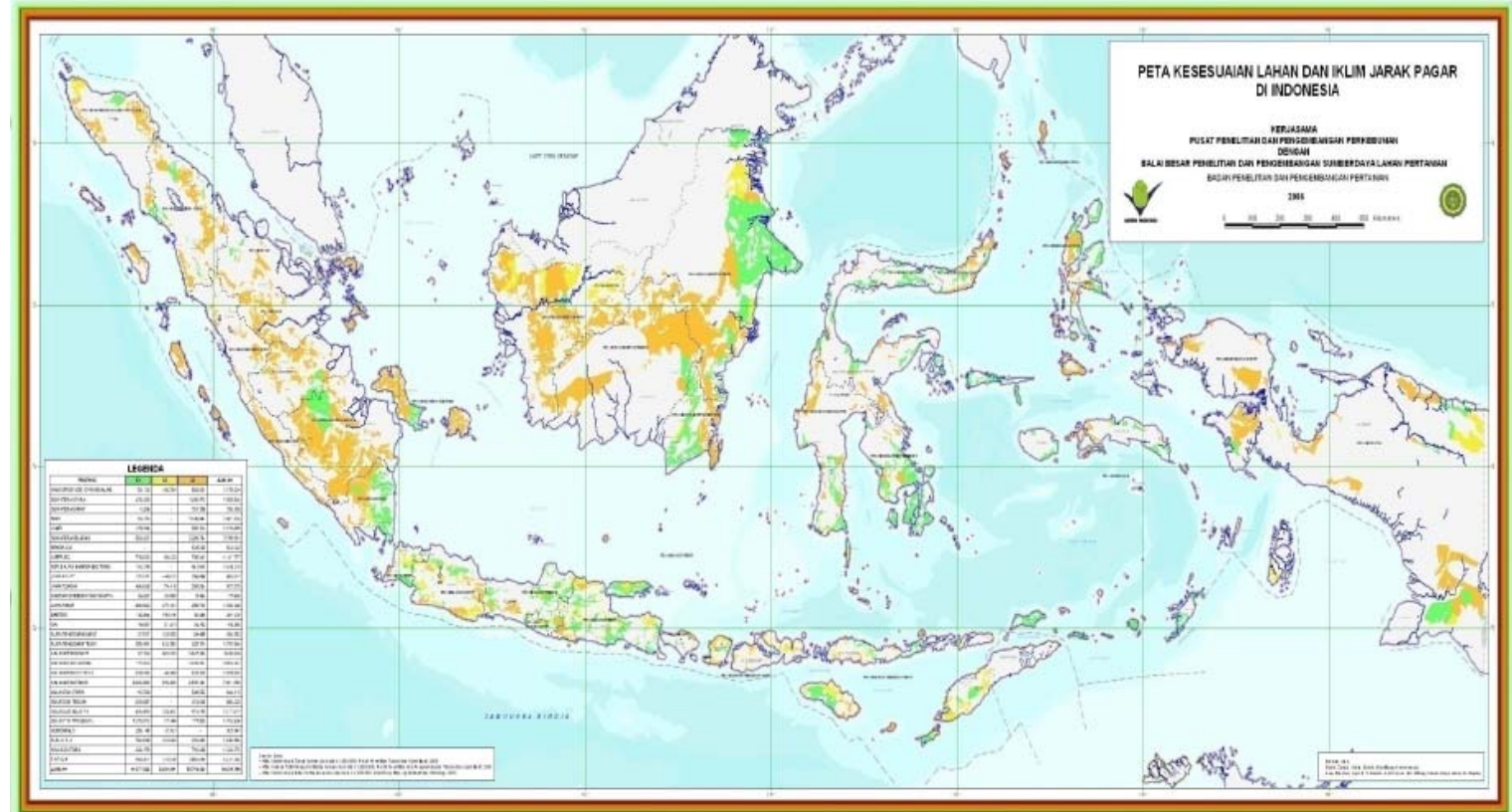

Source: Legowo 2007; green - suitable, yellow - more suitable, orange - very suitable; the table shows hectares identified as suitable for jatropha under each of these land categories

Figure 19. Land Suitable for Jatropha Curcas in Indonesia 


\section{Biomass Resource Assessment Capabilities}

Geospatial Techniques. It is evident from the examples above that Indonesia uses GIS to identify lands suitable for growing different crops. In addition to the Ministry of Energy and Mineral Resources (http://www.esdm.go.id), GIS has been used by the Ministry of Forestry (http://www.dephut.go.id). In the summer of 2008, AAAT's Center of Technology for Natural Resources Inventory and the Japanese Earth Remote Sensing Data Analysis Center began a collaborative project in agricultural analyses using remote sensing techniques. This is the first time these techniques have been used in Indonesia. The output of this cooperative work will be the development of a crop prediction model (AAAT 2008).

Data Availability. Statistics Indonesia - BPS (Badan Pusat Statistik) is the main agency that compiles and disseminates statistics related to agriculture, forestry, industry and other areas. Data is collected via paper and sample ground surveys on an annual basis. Detailed information on BPS and its data-collection methods is provided by FAO's Regional Data Exchange System (RDES 2006). Other agencies that provide agricultural and forestry data by province include the Ministry of Forestry (http://www.dephut.go.id/) and the Ministry of Agriculture (http://www.deptan.go.id). The Indonesian Palm Oil Association (GAPKI) provides statistics on current and historic palm oil production in Indonesia (http://www.gapki.org/).

Institutions with research programs related to biomass that could provide expertise in the field include Indonesian Institute of Sciences (Lembaga Ilmu Pengetahuan Indonesia), which has been involved in research of new and renewable energy, earth science, and provides information technologies services; and the Institute of Technology Bandung with its School of Life Sciences and Technology and the Faculty of Earth Sciences and Technology offering RS and GIS programs.

\section{References}

1. Agency for the Assessment and Application of Technology (AAAT), Remote Sensing to Support National Program for Crop Prediction, accessed June 2008, http://www.bppt.go.id

2. Febijanto, I., Agency for Assessment and Application of Technology (AAAT), Indonesian Renewable Energy Development and Opportunity to Implement CDM Scheme, Asian Science \& Technology Seminar, Jakarta, March 2007, http://www.jst.go.jp/asts/asts j/files/ppt/12 ppt.pdf 
3. International Energy Agency (IEA), Country energy statistics, Oil in Indonesia, 2005. http://www.iea.org/Textbase/country/index.asp

4. Legowo, E., et al., Ministry of Energy and Mineral Resources, presentation at the USDA Global Conference on Agricultural Biofuels, Minnesota, USA, August 2007, http://www.ars.usda.gov/meetings/Biofuel2007/presentations/IP-B/Kussuryani.pdf

5. Regional Data Exchange System (RDES), FAO, Metadata for National Agricultural Statistics - Indonesia, 2006,

6. http://faorap-apcas.org/rdes/PPT/indonesia metadata.pdf

7. Priyanto, U. and Ridlo, R., Agricultural and Wood Waste Potentials and Utilization in Indonesia, Center of Energy Resource Development Technology, Agency for Assessment and Application of Technology (AAAT), presentation at the Fourth Biomass Asia Workshop, November 2007, Malaysia http://www.biomass-asiaworkshop.jp/presentation files/28 Priyant.pdf

8. Wirawan, S.S., Agency for the Assessment and Application of Technology (AAAT), Energy Generation Opportunities from Palm Oil Mills in Indonesia, presentation at the Fourth Biomass Asia Workshop, November 2007, Malaysia, http://www.biomass-asiaworkshop.jp/presentation files/18 Soni.pdf

9. ZREU (Zentrum fur rationell Energieanwendung und Umwelt $\mathrm{GmbH}$ ), Biomass in Indonesia-Business Guide, 2000 


\section{Japan}

\section{Economy-Wide Biofuels Resource Assessments}

This survey identified several biomass resource assessments in Japan. All of them are at an economy-wide level, although statistics are available at prefecture and, in some cases, municipal level. Japan appears to have very good geospatial capabilities to assess the resources at a finer level. It is possible that such assessments exist, but are inaccessible due to language or status constraints. The assessments are based on statistical analysis of reported information.

\section{First-Generation Biofuels Potential}

Ethanol: Japan's potential for production of ethanol from conventional agricultural crops is extremely limited. Even if $20 \%$ of Japan's current starch and sugar crop production could be spared for biofuels, it would only yield about $0.75 \mathrm{hm}^{3}$ of ethanol or $0.36 \mathrm{Mt}$ gasoline equivalent. Such a volume of ethanol would displace just $0.8 \%$ of Japan's current gasoline consumption and $0.2 \%$ of its crude oil imports.

Biodiesel: Japan produces a small amount of oil crops, and biodiesel is produced from used cooking oil in limited quantity. Table 12 illustrates the amount of waste oil and fats generated in 2000 , which totaled some $0.5 \mathrm{Mt}$. If $20 \%$ of Japan's current vegetable oil production were devoted to biofuels, it would yield less than $0.3 \mathrm{Mt}$ of biodiesel. Together with the waste oil and fats, this would provide less than $0.8 \mathrm{Mt}$ of biodiesel. This amount would replace just $2.8 \%$ of the economy's diesel consumption and $0.4 \%$ of its crude oil imports.

Table 12. Quantity of Waste Oil and Fats Generated in Japan

\begin{tabular}{|c|c|c|c|c|c|}
\hline \multirow[t]{2}{*}{ Section } & \multirow[t]{2}{*}{ Oil supply ${ }^{\mathrm{a}}(\mathrm{kt})$} & \multicolumn{3}{|l|}{$\mathrm{CF}$} & \multirow{2}{*}{$\begin{array}{l}\text { Quantity of } \\
\text { waste oil/fat (kt) }\end{array}$} \\
\hline & & $\begin{array}{l}\text { (1) Wastes per } \\
\text { person }\left(\text { g caput }^{-1} \text { ) }\right.\end{array}$ & $\begin{array}{l}\text { (2) Rate of } \\
\text { wastes (\%) }\end{array}$ & $\begin{array}{l}\text { (3) Rate of retum } \\
(\%)\end{array}$ & \\
\hline Household & 650 & 950 & 40 & - & $124^{\mathrm{b}}-261$ \\
\hline Restaurant & 710 & - & 30 & - & 212 \\
\hline Food industry & 689 & - & 10 & - & 21 \\
\hline Oils/fats industry & 429 & - & - & 5 & 69 \\
\hline Total & 2479 & - & - & - & $426-563$ \\
\hline
\end{tabular}

Source: Minami, E., and Saka, S., (2005); a - Ministry of Agriculture, Forestry and Fisheries (MAFF), 2000; $\mathrm{CF}$ - conversion factor of the wastes from (1) number of the population, and $(2,3)$ oil supply;

$\mathrm{b}$ - Estimated assuming that the population of Japan is about $130,000,000$. 


\section{Second-Generation Biofuels Potential}

Agricultural residues were estimated by Matsumura et al. using statistics from 2000. The study considered residues from all major crops grown in Japan and evaluated their energy potential as shown in Table 13. The agricultural residues identified in the table sum to just under $30 \mathrm{Mt}$ in all.

Table 13. Annual Agricultural Residue Production in Japan

\begin{tabular}{lcllllr}
\hline & $\begin{array}{l}\text { Production } \\
\left(\text { tyear }^{-1}\right)\end{array}$ & $\begin{array}{l}\text { Residual ratio } \\
(-)\end{array}$ & $\begin{array}{l}\text { Residue production } \\
\left(\text { tyear }^{-1}\right)\end{array}$ & $\begin{array}{l}\text { Moisture } \\
\text { content }(-)\end{array}$ & $\begin{array}{l}\text { Ash content } \\
(-)\end{array}$ & $\begin{array}{l}\text { Energy potential } \\
\left(\text { PJ year }^{-1}\right)\end{array}$ \\
\hline Rice & $9,472,000$ & 1.43 & $13,544,960$ & 0.2 & 0.22 & 157.2 \\
Wheat & 688,200 & 2.53 & $1,741,146$ & 0.28 & 0.14 & 20.1 \\
Barley & 192,200 & 2.5 & 480,500 & 0.09 & 0.15 & 6.9 \\
Sweet potato & $1,008,000$ & 1.14 & $1,149,120$ & 0.89 & 0.1 & 2.1 \\
Potato & $2,844,000$ & 1.14 & $3,242,160$ & 0.89 & 0.1 & 6.0 \\
Soybean & 235,000 & 2.14 & 502,900 & 0.6 & 0.15 & 3.2 \\
Sugarcane & $1,395,000$ & 0.52 & 725,400 & 0.8 & 0.16 & 2.3 \\
Corn & $5,287,000$ & 1.1 & $5,815,700$ & 0.47 & 0.1 & 51.6 \\
Sorghum & $1,625,000$ & 1.57 & $2,551,250$ & 0.6 & 0.16 & 15.9 \\
\hline
\end{tabular}

Source: Matsumura, Y., et al. in 2005-B

Forest residues were estimated by Yoshioka et al. using statistics from 1999 (waste paper and black liquor are excluded from the analysis). The study estimated that about $32 \mathrm{Mt}$ of woody residues are available annually in Japan. The different types of residues assessed are shown in Table 14.

Table 14. Annual Potential Amount of Woody Biomass in Japan (dry weight)

\begin{tabular}{ll}
\hline Item & $\begin{array}{l}\text { Amount } \\
\left(\mathrm{Tgy}^{-1}\right)\end{array}$ \\
\hline Logging residues $^{\mathrm{a}}$ & 3.0 \\
$\begin{array}{l}\text { Trees to be thinned from coniferous forests } \\
\quad \text { which are behind in tending }\end{array}$ & 5.0 \\
Coppice forests, i.e., broad-leaved forests $^{\mathrm{c}}$ & \\
Bamboo $^{\mathrm{d}}$ & 9.0 \\
Bamboo grass $^{\mathrm{e}}$ & 0.3 \\
Mill residues $^{\mathrm{f}}$ & 3.0 \\
Wood-based waste material $^{\mathrm{g}}$ & 0.4 \\
Trimmings of park trees, roadside trees, and $^{\text {garden trees }}{ }^{\mathrm{h}}$ & 8.0 \\
Total $^{\text {The }}$ & 3.0 \\
\hline
\end{tabular}


Source: Yoshioka, T., et al. (2005); ${ }^{a}$ Includes thinned trees that are left in forests because the logging costs are higher than the timber price; ${ }^{b}$ Cutting the forests which should have been thinned with the thinning rate of $20 \%$; ${ }^{c}$ Cutting the broad-leaved forests (excluding the forests for logs and bed-logs for shiitake mushroom production) less than 500m from forest roads with the cutting cycle of 30 years.; ${ }^{\mathrm{d}}$ Harvesting $30 \%$ of the annual amount of $1.0 \mathrm{Tg} / \mathrm{yr}$ dry-weight basis; ${ }^{\mathrm{e}}$ Harvesting the grass less than a certain distance from forest roads.; ${ }^{f}$ Covering all of the wood industries; ${ }^{9}$ Consisting of demolition woods, wastes from new construction, and old materials of pallets and packages; ${ }^{\mathrm{h}}$ Net primary production of the park, roadside, and garden trees; Tg (Teragram) $=1$ Megatonne

A more up to date analysis on biomass resources is provided by the Ministry of Agriculture, Forestry and Fisheries (MAFF). In addition to estimating the total amount of resources available in Japan, the agency provided the utilized and unutilized portions of these resources as presented in Table 15. Crop and wood residues amount to about $26.3 \mathrm{Mt}$, but only $15 \mathrm{Mt}$ are not utilized and therefore available for biofuels production in Japan. These surplus residues would yield $4.5 \mathrm{GL}$ of ethanol per year or $2.2 \mathrm{Mt}$ gasoline equivalent, enough to replace $5 \%$ of gasoline consumption and $1 \%$ of crude oil imports.

Table 15. Utilization of Biomass Resources in Japan, 2006

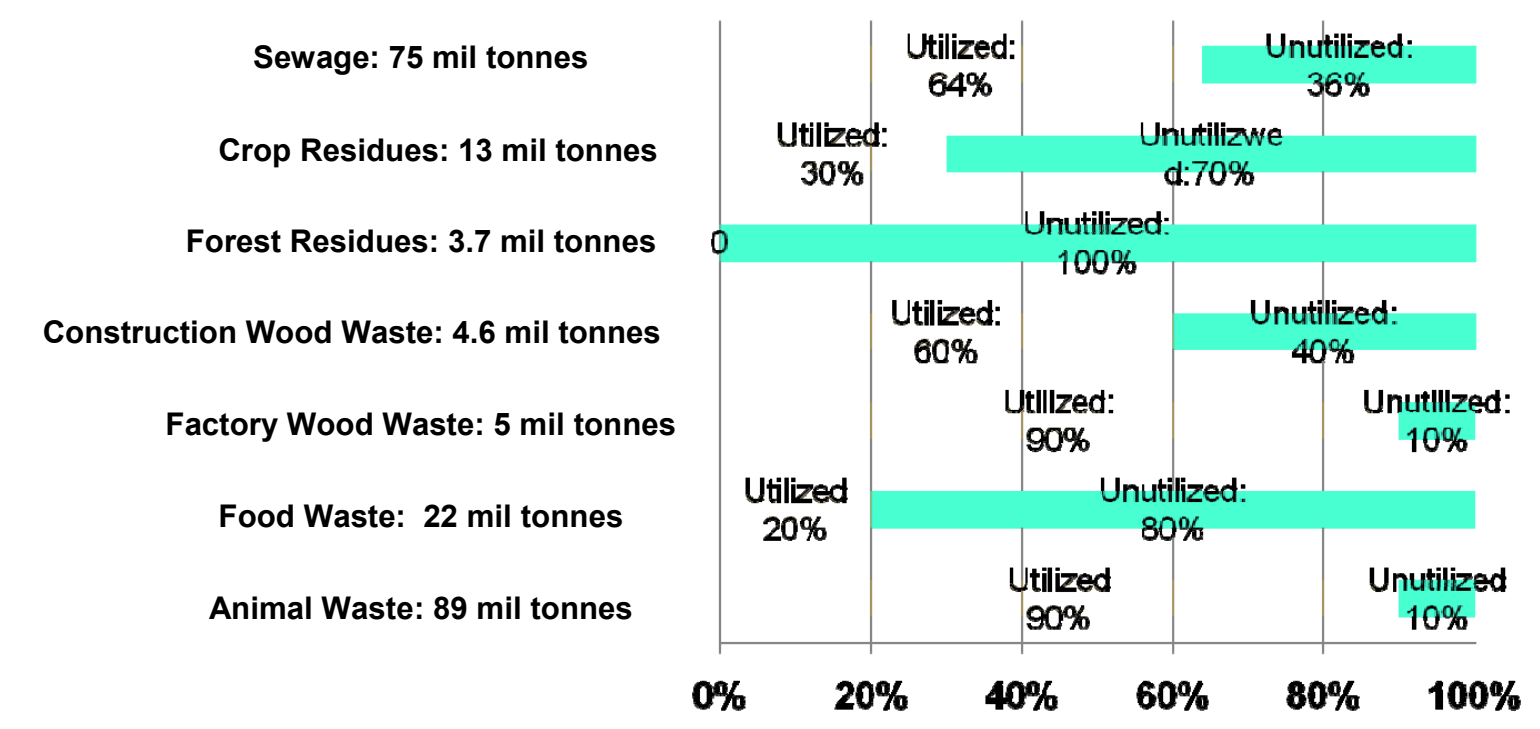

Source: Takao Ikeda, 2008, http://www.maff.go.jp/j/biomass/pdf/riyou_jyokyou.pdf

To further promote domestic ethanol production, the government hopes to use abandoned arable land. In 2005, Yamamoto et al. estimated the land available for growing dedicated energy crops, but the study does not specify the types of energy crops that could be grown. It concludes that about 400,000 ha of unused arable land are available in Japan for growing energy crops and that another 1.2 million ha could be used for double-cropping with conventional crops. If such land were cultivated, the potential for second-generation biofuels to displace petroleum would be enhanced. 


\section{Biomass Resource Assessment Capabilities}

Japan appears to have advanced modeling and geospatial capabilities; however, no analysis of biomass resources using these methods was identified during this survey. MAFF has been using mathematical modeling to estimate crop yield and predict production. The Forestry Agency has been promoting the use of GIS/GPS as efficient tools for collecting, recording, and updating data to the prefectural governments. GIS and RS have also been used by several universities to support research activities.

Academic institutions that have been involved in analyses of agricultural and forestry resources include:

- Department of Mechanical System Engineering, School of Engineering, Hiroshima University

- Department of Forest Science and Resources, College of Bio-resource Sciences, Nihon University, Fujisawa

- School of Agriculture, Kyoto University

- Natural Resources and Energy Division, Mizuho Information \& Research Institute Inc., Tokyo

- Forestry and Forest Products Research Institute

- Biomass Recycle Research Laboratory, National Institute of Advanced and Industrial Science and Technology, Hiroshima

- Biomass Technology Research Laboratory, National Institute of Advanced Industrial Science and Technology, Chugoku

- Research Institute of Energy Utilization, National Institute of Advanced Industrial Science and Technology, Ibaraki

- Global Warming Research Department, Mitsubishi Research Institute Inc., Tokyo

- Technical Institute, Kawasaki Heavy Industries Ltd, Hyogo

- Socioeconomic Research Center, Central Research Institute of Electric Power Industry, Tokyo

- Seikei University, Fukuoka

- Ehime University, Matsuyama 
Institutions with geospatial capabilities include:

- Center for Spatial Information Science, University of Tokyo

- Center for Environment Remote Sensing (CEReS), Chiba University

- Japanese Earth Remote Sensing Data Analysis Center (ERSDAC), Tokyo

- Institute of Industrial Science, University of Tokyo

- National Institute for Rural Engineering

Data Availability. MAFF (http://www.maff.go.jp/) is in charge of Japan's agricultural and forestry statistics. It provides annual data on crop acreages and production, livestock, and forestry products by prefecture and, in some cases, municipality. The agricultural data is collected through direct interviews with farm owners. Due to the different climate and types of agriculture among Hokkaido, Okinawa, and the other prefectures, three sets of farm household questionnaires were used, in the simplified and detailed format, reporting different items (FAO 2000). The Forestry Agency established the Forest Resources Monitoring System in 1999 to monitor changes in quality and quantity of forests in Japan. Under the system, data are collected on about 15,700 permanent monitoring plots, 10,500 of which are located in private forests and the rest in national forests. The plots have been chosen systematically on $4 \mathrm{~km} x$ $4 \mathrm{~km}$ grid points covering forests throughout Japan. The system is designed so that data is collected on about 3,100 plots (or one-fifth of the total number of plots) annually with each plot visited every 5 years in rotation (Imaizumi 2001).

\section{References}

1. Imaizumi, Y., Data and Information Collection for Sustainable Forest Management in Japan, Forestry Agency, November 2001, http://www.rinya.maff.go.jp/mar/Mr.\%20Imaizumi\%20Paper.pdf

2. International Energy Agency (IEA), Country energy statistics, Oil in Japan, 2005. http://www.iea.org/Textbase/country/index.asp

3. Institute of Energy Economics Japan (IEEJ), Japan's Ethanol Introduction and Outstanding Issues, October 2007, http://eneken.ieej.or.jp/en/data/pdf/403.pdf

4. FAO, Japan - Agricultural Census 2000 - Main Results, http://www.fao.org/es/ESS/census/wcares/Japan 2000.pdf

5. Matsumura, Y., et al. (2005-A), "The Scale of Biomass Production in Japan”, Biomass \& Bioenergy, 29: 321-330

6. Matsumura, Y., et al. (2005-B), "Amount, availability, and potential use of rice straw (agricultural residue) biomass as an energy resource in Japan", Biomass \& Bioenergy, 29: $347-354$ 
7. Minami, E., and Saka, S., (2005), "Biomass resources present in Japan-annual quantities grown, unused and wasted". Biomass \& Bioenergy, 29: 310-320

8. Minowa, T., et al., (2005), "Study for utilization of municipal residues as bioenergy resource in Japan", Biomass \& Bioenergy, 29: 360-366

9. Takao Ikeda, The Institute Energy Economics, Presentation at APEC Biofuels Task Force Meeting, Golden, Colorado, USA, October 7-9, 2008, data source: http://www.maff.go.jp/i/biomass/pdf/riyou jyokyou.pdf

10. Yamamoto, H., et al., (2005), "Evaluation of supply potential of energy crops in Japan considering cases of improvement of crop productivity", Biomass \& Bioenergy, 29: 355359

11. Yoshioka, T., et al. (2005), "Woody biomass resources and conversion in Japan: The current situation and projections to 2010 and 2050", Biomass \& Bioenergy, 29: 336-246 


\section{Korea}

\section{Economy-Wide, Regional, and Local Biofuels Resource Assessments}

\section{First-Generation Biofuels Potential}

Ethanol: Korea's potential for production of ethanol from conventional agricultural crops is considered to be quite limited. Even if $20 \%$ of Korea's current rice production could be spared for conversion to biofuels, it would only yield about $0.33 \mathrm{hm}^{3}$ of ethanol or $0.16 \mathrm{Mt}$ gasoline equivalent. This amount of ethanol could displace just $2.3 \%$ of Korea's current gasoline consumption and $0.1 \%$ of its current crude oil imports.

Biodiesel: Biodiesel is considered the primary biofuel in Korea since the economy consumes twice as much diesel as gasoline and has real domestic production potential. About $70-80 \%$ of biodiesel in Korea is produced from imported soybean oil and $20-30 \%$ from used cooking oil. Several biodiesel plants have the capability of using palm oil. Due to increasing soybean and palm oil prices, biodiesel producers are considering alternative feedstocks such as jatropha oil produced in Southeast Asia.

Used cooking oil in Korea amounts to some 0.2 Mtoe annually (Lee and Park 2006), which could yield about $0.23 \mathrm{Mt}$ of biodiesel. ${ }^{5}$ If $20 \%$ of Korea's current soybean oil production were also devoted to biodiesel production, it could yield about another $0.03 \mathrm{Mt}$. The overall potential of $0.26 \mathrm{Mt}$ of biodiesel from soybean and cooking oil would replace just $1.8 \%$ of the economy's current diesel consumption and $0.2 \%$ of its current crude oil imports.

\section{Second-Generation Biofuels Potential}

Ethanol: KIER's Bioenergy Research Laboratory is developing a National Biomass Resources Atlas. The project, which began at the end of 2006, includes maps of forest and agricultural residues at an economy-wide, regional, and county level. The estimates are based on statistical information collected through paper surveys. Field surveys are conducted occasionally in

\footnotetext{
${ }^{5}$ Assuming 1 tonne of biodiesel $=0,86$ toe
} 
assessing and monitoring agricultural and forest residues. The atlas and its underlying data are available to the public via the Internet, but only in Korean.

Table 16 notes that agricultural residues in Korea amount to about $11.8 \mathrm{Mt}$. Additionally, about 1.3 Mt of logging residues are generated annually (Park S. et al 1993), thus second generation feedstock in Korea amounts to about 13.1 Mt. This amount could produce $3.9 \mathrm{hm}^{3}$ of ethanol or 1.9 Mt gasoline equivalent. Such a volume of ethanol could displace $27 \%$ of current gasoline consumption and $1.7 \%$ of current crude oil imports in Korea.

Table 16. Agricultural Residues in Korea

\begin{tabular}{|l|c|}
\hline \multicolumn{1}{|c|}{ Residues } & Amount produced (1000MT) \\
\hline Rice straw & 8,228 \\
Rice hull & 1,487 \\
Barley straw & 560 \\
Misc. grain residue & 141 \\
Pulse residue & 444 \\
Special crop residue & 328 \\
Potatos residue & 187 \\
Fruit production residue & 468 \\
Misc. & - \\
\hline Total & 11,843 \\
\hline Source: Park S. et al., KIER 1993 &
\end{tabular}

Biodiesel: The Korea Institute of Energy Research (KIER) is researching the potential for growing winter canola domestically as a biodiesel feedstock. The coastal regions were identified as suitable for production of this crop (Figure 20) and about 300,000-500,000 ha were estimated to be available for planting. Expected canola production would be between $0.45 \mathrm{Mt}$ and $0.75 \mathrm{M}$ t per year. These amounts could displace an additional $3 \%$ to $5 \%$ of the economy's current diesel consumption and an extra $0.3 \%$ to $0.5 \%$ of crude imports. 


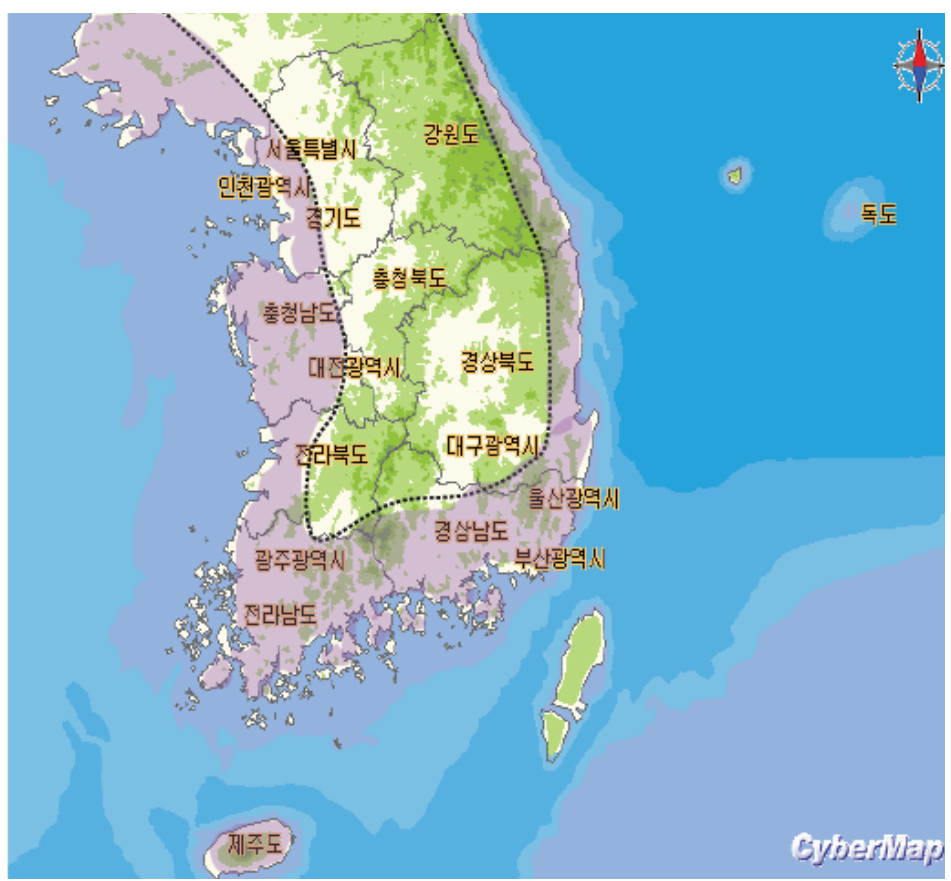

Source: KIER, 2006

Figure 20. Areas Suitable for Winter Canola in Korea

\section{Biomass Resource Assessment Capabilities}

KIER appears to be the main institution involved in biomass resource assessment activities. A few other organizations are involved in agricultural or forestry research so may have the potential to contribute to resource assessment efforts. These include the National Institute of Agricultural Science and Technology, Korea Forest Service, Korea Forest Research Institute, and Korea Rural Economic Institute.

Several universities have been involved in research related to forestry monitoring and assessment using remote sensing and GIS. These include Kyungil University, Chungbuk National University, Kyungpook National University, Ewha Womans University, Seoul National University, and Korea University.

The Korea National Statistical Office (KNSO) provides statistical information on agriculture and forestry. The data is collected via surveys with questionnaires prepared and sent out to farmers. KNSO has been conducting agricultural and forestry surveys every five years since 1960 . 


\section{References}

1. International Energy Agency (IEA), Country energy statistics, Oil in Korea, 2005. http://www.iea.org/Textbase/country/index.asp

2. Korea Forest Research Institute, accessed January 2008, http://www.kfri.go.kr/eng/

3. Korea Forest Service, accessed January 2008, http://english.forest.go.kr/

4. Korea Institute of Energy Research (KIER), accessed January 2008, http://kier.re.kr/english/index.html

5. Korea National Statistical Office (KNSO), accessed January 2008, http://www.nso.go.kr

6. Korea Rural Economic Institute, accessed January 2008, http://www.krei.re.kr/eng/index.php

7. Lee, Jin-Suk and Park, Soon-Chul, Bioenergy Research Center, KIER, Biomass Potentiality and Utilization in Korea, November 2006

8. Myung-Hee Jo, et al., The Development of Forest Fire Forecasting System using Internet GIS and Satellite Remote Sensing, paper presented at the 21-st Asian Conference on Remote Sensing, Taipei, Chinese Taipei, 2000

9. National Institute of Agricultural Science and Technology, accessed January 2008, http://www.niast.go.kr/english/main.asp

10. Park, Soon-Chul, et al., KIER, State of art in Utilization of Agricultural Residues and Identification of Priority Biomass Energy projects in the Republic of Korea, 1993, http://www.yeskisti.net/yesKISTI/InfoSearch/ReadDB01.jsp?CNO=CFKO199311922467 493

11. U.S. Department of Agriculture, Biofuels Korea, GAIN Report, 2007, http://www.fas.usda.gov/gainfiles/200708/146292125.pdf 


\section{Malaysia}

\section{Economy-Wide Biofuels Resource Assessments}

\section{First-Generation Biofuels Potential}

Ethanol: Ethanol from first generation feedstock is currently not considered viable in Malaysia. Grain production in the economy (rice in particular) totals just $1.4 \mathrm{Mt}$. If $20 \%$ of this amount could be made available for biofuel feedstock, for example through increase in productivity over time, the resulting ethanol would amount to just $0.10 \mathrm{hm}^{3}$ or $0.048 \mathrm{Mt}$ gasoline equivalent. That would be sufficient to displace $1 \%$ of the economy's current gasoline consumption or $0.6 \%$ of its current crude oil imports.

Biodiesel: Malaysia concentrates primarily on biodiesel production, particularly from palm oil. Malaysia was the world's largest palm oil producer for many years but was surpassed by Indonesia in 2007. Together, these economies produce about $90 \%$ of the world's palm oil. In Malaysia, nearly $11 \%$ of the total land area (about $62 \%$ of the economy's agricultural land) is devoted to oil palm. Production more than doubled in a little over a decade, from $8 \mathrm{Mt}$ in 1995 to $16 \mathrm{Mt}$ in 2006. Malaysian government policy currently allows only $6 \mathrm{Mt}$ of palm oil to be converted into biodiesel, and a large portion of this production is intended for export. If $20 \%$ of Malaysia's current palm oil production were used for biofuels, it would yield about $3.2 \mathrm{Mt}$ of biodiesel. This amount would replace $64 \%$ of the economy's current diesel consumption and $41 \%$ of its crude oil imports.

\section{Second-Generation Biofuels Potential}

Ethanol: Abundant biomass resources are generated from oil palm, paddy, sugar, and woodprocessing industries. The National Energy Research Center, Pusat Tenaga Malaysia (PTM), estimated the amount of these resources as illustrated in Table 17 (Rahman 2007). The study states that bagasse is already in use by the sugar mills for power and steam generation, and that wood waste residues are declining due to the use of modern equipment (which generates fewer residues) or are used for the manufacture of charcoal, briquettes and processed heat through gasification. Based on the results presented in Table 17, Malaysia generates more than 
$32 \mathrm{Mt}$ of oil palm, paddy, wood residues, and bagasse annually. If all used for biofuel, this would yield roughly $9.7 \mathrm{hm}^{3}$ of ethanol or $4.6 \mathrm{Mt}$ gasoline equivalent. That would displace about $60 \%$ of current gasoline consumption and $59 \%$ of crude oil imports.

Table 17. Biomass Residue Generation in Malaysia

\begin{tabular}{|c|c|c|c|c|c|c|}
\hline $\begin{array}{l}\text { Type of } \\
\text { Industry }\end{array}$ & $\begin{array}{c}\text { Production } \\
\text { (Thousand Tonne) }\end{array}$ & Residue & $\begin{array}{c}\text { Residue } \\
\text { product Ratio } \\
(\%)\end{array}$ & $\begin{array}{l}\text { Residue Generated } \\
\text { (Thousand Tonne) }\end{array}$ & $\begin{array}{c}\text { Potential } \\
\text { Energy } \\
\text { PJ }\end{array}$ & $\begin{array}{c}\text { Potential } \\
\text { Elec } \\
\mathrm{MWe}\end{array}$ \\
\hline \multirow{5}{*}{ Oil palm } & \multirow{3}{*}{74,272} & EFB & 21.14 & 15,701 & 74 & 714 \\
\hline & & Fiber & 12.72 & 9,447 & 140 & 1,353 \\
\hline & & Shell & 5.67 & 4,211 & 71 & 683 \\
\hline & \multicolumn{2}{|l|}{ Total } & & 29,360 & 285 & 2,750 \\
\hline & \multicolumn{2}{|l|}{ Others(POME) } & & 51,990 & 30 & 428 \\
\hline \multirow{2}{*}{ Paddy } & \multirow{2}{*}{2,141} & Rice Husk & 22 & 471 & 7.6 & 72 \\
\hline & & Paddy Straw & 40 & 856 & 8.8 & 80 \\
\hline Sugar & 1,111 & Bagasse & 32 & 356 & 356 & 314 \\
\hline \multirow{3}{*}{ Wood } & $2,937,679 \mathrm{~m} 3$ & Sawn timber & $0.5-0.6$ & $1,692,718 \mathrm{~m} 3$ & 5.2 & 50 \\
\hline & 523,336 & $\begin{array}{l}\text { Plywood and } \\
\text { veneer }\end{array}$ & $0.18-0.65$ & $121,000 \mathrm{~m} 3$ & 0.374 & 4 \\
\hline & 147,813 & Moulding & $0.2-1.0$ & $75,600 \mathrm{~m} 3$ & 0.232 & 2 \\
\hline
\end{tabular}

Biodiesel: A potential biodiesel feedstock considered in Malaysia is jatropha. Jatropha is still in the very early stage of development and efforts appear to be focused on small scale plantations.

\section{Biomass Resource Assessment Capabilities}

Although this survey didn't yield any detailed biomass resource assessments, it appears that these capabilities are present in Malaysia. Institutions that have been involved in assessing biomass resources include the National Energy Research Center - Pusat Tenaga Malaysia (PTM); the Forest Research Institute Malaysia (FRIM), University Putra Malaysia (UPM); and the School of Mechanical Engineering - University Science Malaysia, Pulau Pinang.

Geospatial Techniques. RS and GIS technologies started to advance in Malaysia in the 1980s, particularly in the natural resources field. The effective use of these technologies in assessing and monitoring forest resources - at a reduced cost, time, and labour compared to conventional 
practices - prompted the government to establish the Malaysian Centre of Remote Sensing (MACRES) in 1988 (UMS 2008). MACRES established an operational remote sensing-based integrated natural resource and environmental database at the economy-wide level to support planning and decision making. While MACRES is the leading agency for remote sensing applications, research on the subject is also carried out by universities such as University Technology Malaysia (UTM), University Putra Malaysia (UPM), University Kebangsaan Malaysia (UKM), and University Malaysia Sabah (UMS). Remote sensing user agencies include the Malaysia Agriculture Research and Development Institute (MARDI) and the Forest Research Institute of Malaysia (FRIM). Remote sensing for forestry applications undertaken by FRIM includes forest inventory, mapping, rehabilitation, and monitoring. Microwave remote sensing is expected to improve the coverage of critical areas. At MARDI, past research included crop surveillance and a land resource inventory; while current research activities cover, among other things, spatial modeling for regional agricultural development and characterization of plant species (Global Security 2008).

Data availability. Malaysia maintains very good agricultural and forestry statistics provided by the following agencies: forestry statistics by state is available from the Forestry Department, Peninsular Malaysia (FDPM) at http://www.forestry.gov.my/stat kand.html; the Ministry of Agriculture and Agro-Based Industry (MOA) collects and reports data on agricultural products at http://www.moa.gov.my/. The Malaysian Timber Council provides statistics on timber products at http://www.mtc.com.my and the Malaysian Palm Oil Board (MPOB) provides statistics on the palm oil production (http://mpob.gov.my/).

\section{References}

1. Ali Hassan, M., Shirai, Y., University Putra Malaysia (UPM), Malaysia : Sustainable Biomass Production and Utilization, presentation at Biomass-Asia Workshop, Selangor Darul Ehsan, Malaysia, November 2007, http://www.biomass-asiaworkshop.jp/presentation files/13 AliHassan.pdf

2. Center for Remote Sensing and GIS, University of Malaysia, Sabah, Accessed April 2008, http://www.ums.edu.my/appl/index.php? mod=Publication\&action=introaccess\&sek=prsg \&lang= en

3. Forest Research Institute Malaysia (FRIM), Accessed April 2008, http://www.frim.gov.my/

4. www.GlobalSecurity.org, Malaysia and Earth Observation Systems, Accessed April 2008, http://www.globalsecurity.org/space/world/malaysia/earth.htm

5. Hamzah, A., K., Forest Research Institute Malaysia (FRIM), Remote Sensing, GIS and GPS as Tools to Support Precision Forestry Practices in Malaysia, paper presented at 
the $22^{\text {nd }}$ Asian Conference on Remote Sensing, Singapore, November 2001, http://www.crisp.nus.edu.sg/ acrs2001/pdf/276HAMZA.PDF

6. Husain, Z., et al. (2003), "Analysis of biomass-residue-based cogeneration system in palm oil mills", Biomass \& Bioenergy, 24: 117-124

7. International Energy Agency (IEA), Country energy statistics, Oil in Malaysia, 2005. http://www.iea.org/Textbase/country/index.asp

8. Kong, H., W., Forest Research Institute Malaysia (FRIM), Current Status of Biomass Utilization in Malaysia, abstract submitted at the Biomass-Asia Workshop, Tokyo, Japan, January 2005, http://www.biomass-asiaworkshop.jp/biomassws/01workshop/material/Hoi\%20Why\%20Kong-word.pdf

9. Koh, M., P., Forest Research Institute Malaysia (FRIM), Desk Study on National Wood fuels and Wood Energy Information Analysis, Kuala Lumpur, April 2002, http://www.rwedp.org/acrobat/Malaysia ECFPP.pdf

10. Koh, M., P. and Hoi, W., K. (2003), "Sustainable biomass production for energy in Malaysia", Biomass \& Bioenergy, 25: 517-520

11. Pusat Tenaga Malaysia (PTM), Accessed in April 2008, http://www.ptm.org.my/

12. Rahman, A., A., Pusat Tenaga Malaysia (PTM), Biomass for Energy Generation in Malaysia, presentation at Biomass-Asia Workshop, Selangor Darul Ehsan, Malaysia, November 2007, http://www.biomass-asiaworkshop.jp/presentation files/03 Anuar.pdf 


\section{Mexico}

\section{Economy-Wide Biofuels Resource Assessments}

\section{First-Generation Biofuels Potential}

Ethanol: Mexico grows several crops that could be used as feedstock for ethanol production, including grain sorghum, corn, wheat, and sugar cane. However, sugar cane is considered the most feasible feedstock due to the opportunity for co-locating ethanol refineries with existing sugar mills. Also, Mexico is a sugar exporter, while it imports large amounts of the other crops mentioned above.

A study by the Energy Secretariat (SENER), the Inter-American Development Bank (BID), and the German Agency for Technical Cooperation (GTZ) in 2006 analyzed the potential of the main crops in Mexico for ethanol production, concluding that three of them (corn, grain sorghum, and sugar cane) could be considered. These crops today use a significant area, as seen in Table 18.

Table 18. Areas and Production for Select Crops in Mexico, 2004

\begin{tabular}{|l|c|c|c|c|}
\hline Crops & $\begin{array}{c}\text { Rain fed } \\
\mathrm{M} \text { ha }\end{array}$ & $\begin{array}{c}\text { Irrigated } \\
\mathrm{M} \text { ha }\end{array}$ & $\begin{array}{c}\text { Total } \\
\mathrm{M} \text { ha }\end{array}$ & $\begin{array}{c}\text { Production } \\
\mathrm{M} \mathrm{t} / \text { year }\end{array}$ \\
\hline \hline Corn (annual) & 7.08 & 1.33 & 8.41 & 21.70 \\
\hline Sorghum (annual) & 1.60 & 0.35 & 1.95 & 7.00 \\
\hline Sugar cane (perennial) (1) & 0.24 & 0.37 & 0.61 & 47.80 \\
\hline
\end{tabular}

Source: SENER-BID-GTZ, 2006; (1) - 2003/04

The study also illustrates the approximate areas needed to support ethanol production in three scenarios:

Scenario 1: Substitute MTBE with ETBE as oxygenate in gasoline

Scenario 2: Total replacement of ethers with ethanol at $5.7 \%$

Scenario 3: Ethanol 10\% blend becomes the standard gasoline in Mexico

Two crops (sugar cane and sugar beets) would require less than 1 million ha to produce enough ethanol for $10 \%$ of gasoline substitution (Scenario 3 ). This seems to be within the possibilities today, because agriculture uses only 21.8 million ha (2003) out of about 30 million ha "available" area; and pasture land (27.7 million ha) in some regions (South-Southeast) could be partly used 
for energy crops. Corn also would be in this range, while cassava and sorghum would require much larger areas (SENER-BID-GTZ). Table 19 summarizes the results of this analysis.

Table 19. Areas Needed for Ethanol Production in Mexico

\begin{tabular}{|c|c|c|c|c|c|c|}
\hline & \multicolumn{2}{|c|}{ Productivity, t/ha } & \multirow{2}{*}{$\begin{array}{c}\text { Conversion, } \\
\text { l ethanol / } \\
\text { (8) }\end{array}$} & \multicolumn{3}{|c|}{$\begin{array}{c}\text { Areas needed, } 2010 \\
\text { M ha (4) }\end{array}$} \\
\hline & $\begin{array}{l}\text { Average } \\
\text { today }\end{array}$ & $\begin{array}{l}\text { Expected } \\
\text { (1) }\end{array}$ & & Scenario 1 & Scenario 2 & Scenario 3 \\
\hline Sugar Cane & 74 & $65 \quad(2)$ & $83(3)$ & 0.08 & 0.21 & 0.85 \\
\hline Corn & 2.8 & $9.1 \quad(5)$ & 400 & 0.11 & 0.32 & 1.26 \\
\hline Sorghum (grain) & 2 & $2 \quad(6)$ & 400 & 0.51 & 1.44 & 5.73 \\
\hline Cassava & & $10.6(10)$ & 170 & 0.23 & 0.64 & 2.54 \\
\hline Wheat & 6.0 & $6.0(7)$ & 440 & 0.16 & 0.44 & 1.73 \\
\hline Sugar beets & 40 & $85-60 \quad(9)$ & $86(12)$ & $0.06-0.09$ & $0.16-0.11$ & $0.63-0.89$ \\
\hline
\end{tabular}

(1) For the conditions (irrigation or rain fed, etc) proposed in the scenarios

(2) For rain fed areas (indicated for expansion to produce ethanol). Except for Tabasco and some areas of Chiapas and Veracruz (sufficient rain) all other areas will need at least two water applications to reach $\sim 70 \mathrm{t}$ cane / ha (Lazcano 2006b)

(3) New distilleries; from the average in Brazil (2002) corrected by the pol\% cane.

(4) Scenario 1: $\quad 0.412 \mathrm{M} \mathrm{m}^{3}$ ethanol / year

Scenario 2: $\quad 1.153 \mathrm{M} \mathrm{m}^{3}$ ethanol / year

Scenario 3: $\quad 4.582 \mathrm{M} \mathrm{m}^{3}$ ethanol / year

(5) With irrigation; Mar de Cortés, Center-North of Sinaloa; as proposed (Lazcano 2006b)

(6) Rain fed; as proposed, in the San Fernando Tamps, Pacifico Norte (Lazcano 2006b)

(7) With irrigation; Valles de Mexicali, del Yaki and B.C. (Lazcano 2006b)

(8) In all cases (when applicable) the use of cellulosic residues to produce ethanol from hydrolysis is not considered in this table, although it is included (with the necessary restrictions) in the study.

(9) With irrigation; as proposed, in the Valle de Mexicali and may be the Valle del Fuerte, Sinaloa (Lazcano 2006b) the value of 85 would be achieved. The second value $(\sim 60)$ is the average 5-year productivity (2000-2004) for the best producers in Europe (France, Germany, Belgium), (F O Lichts 2005).

(10) Rain fed; Bajo Papaloapan, Peninsular

(11) This was the world average in 2000; in many conditions higher values can be obtained (soils, water) (FAO 2002)

(12) See (El Sayed, Matthews and Mortimer 2005)

Source: SENER-BID-GTZ, 2006

If the equivalent of $20 \%$ of Mexico's current starch and sugar crop production could be spared for biofuels production, for example through increase in crop yields over time, it would yield 
about $3 \mathrm{hm}^{3}$ of ethanol or $1.5 \mathrm{Mt}$ gasoline equivalent. This volume would displace $5 \%$ of Mexico's current gasoline consumption. Alternatively, if Scenario 3 in the SENER analysis could be realized, with $4.6 \mathrm{hm}^{3}$ of annual ethanol production, about $8 \%$ of gasoline consumption could be displaced.

Biodiesel: Biodiesel in Mexico is produced from animal fat and used cooking oil. Because of the existing import dependency for animal and recycled oils/fats, the SENER-BID-GTZ study concluded that these feedstocks are going to play a minor role in domestic biodiesel production.

The economy is highly dependent on imports of oilseeds and products (about $90 \%$ oilseeds and approximately $35 \%$ fodder). However, the SENER-BID-GTZ study analyzed the possibility of producing more vegetable oils domestically to support biodiesel production. Accounting for the biodiesel yields per hectare for the different oil crops, the study estimated the acreages needed to support different biodiesel-blend scenarios (Table 20). The study states that if Mexico wants to achieve a self-sufficient supply of biodiesel feedstock considering currently planted and needed land, an intensive agricultural supporting scheme needs to be established. Figure 21 shows areas suitable for growing these crops.

If the equivalent of $20 \%$ of Mexico's current vegetable oil production were used for biofuels, it would yield about $0.23 \mathrm{Mt}$ of biodiesel per annum. This volume would displace less than $2 \%$ of the economy's current diesel consumption.

Table 20. Agricultural Land Needed to Support Biodiesel Feedstock Production in Mexico

\begin{tabular}{|l|r|r|r|r|r|r|}
\hline \multicolumn{1}{|c|}{ Crop } & Yield (L/ha) & \multicolumn{2}{|c|}{ Agricultural Land (ha) Needed to Support: } & $\begin{array}{c}\text { Current Growing } \\
\text { Area (ha) }\end{array}$ & Potential Area (ha) \\
\hline & & B5 & B10 & B20 & & \\
\hline Oil Palm & 3,390 & 304,881 & 609,762 & $1,219,524$ & 15,000 & N/A \\
\hline Jatropha & 730 & $1,415,717$ & $2,831,434$ & $5,666,868$ & 900 & $1,000,000$ \\
\hline Sunflower & 665 & $1,554,095$ & $3,108,190$ & $6,216,381$ & 10,500 & N/A \\
\hline Canola & 619 & $1,669,585$ & $3,339,171$ & $6,678,341$ & 224,000 & N/A \\
\hline Safflower & 409 & $2,526,830$ & $5,053,659$ & $10,107,319$ & 110,000 & $>1,000,000$ \\
\hline Soybeans & 289 & $3,576,032$ & $7,152,065$ & $14,304,129$ & & \\
\hline
\end{tabular}




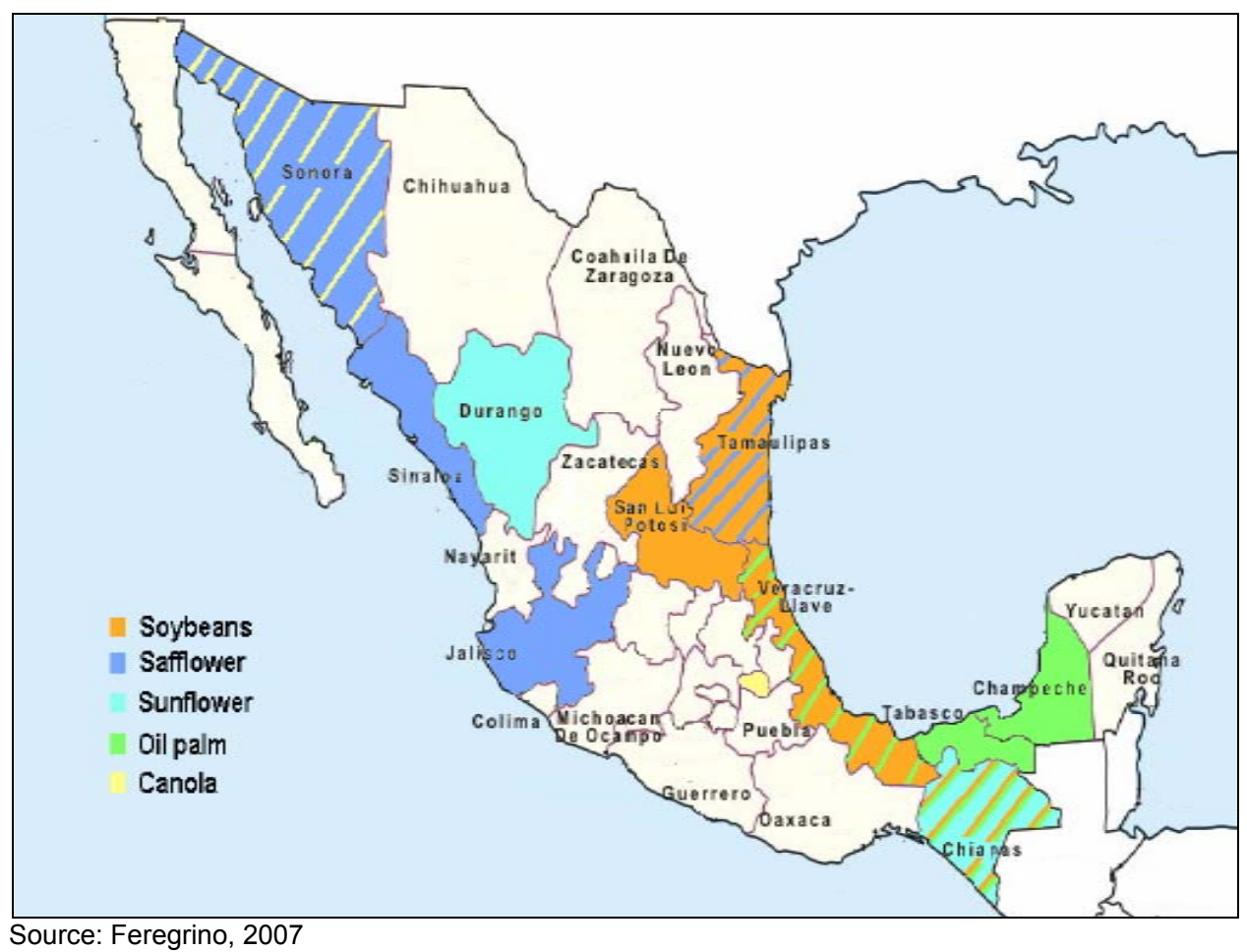

Figure 21. Suitable Areas for Biodiesel Feedstock Production in Mexico

\section{Second-Generation Biofuels Potential}

Ethanol: A study sponsored by the National Forest Commission (CONAFOR) and the National Association of Solar Energy (ANES) estimated the amount of logging, primary mill, and crop residues (CONAFOR/ANES 2006) in Mexico. This is a nationwide study based on statistical analysis of reported information in 2001 - 2003. Crop residues evaluated in this analysis include those from sugar cane, rice, corn, wheat, grain sorghum, barley, and beans production. Total residues are estimated at $74.5 \mathrm{Mt}$ per year (Table 21), which could generate $22 \mathrm{hm}^{3}$ of ethanol or 10.7 Mt gasoline equivalent. Mexico consumed about 27.7 Mt of gasoline in 2005, so secondgeneration ethanol could displace about $39 \%$ of its gasoline consumption.

Table 21. Lignocellulosic Biomass Potential in Mexico

\begin{tabular}{|l|c|}
\hline \multicolumn{1}{|c|}{ Feedstock } & $\begin{array}{c}\text { Quantity (million } \\
\text { tonnes/year) }\end{array}$ \\
\hline Logging Residues & 2 \\
\hline Primary Mill Residues & 1.5 \\
\hline Crop Residues & 71 \\
\hline Total & 74.5 \\
\hline
\end{tabular}

Source: CONAFOR, 2006 
Biodiesel: A potential biodiesel feedstock considered in Mexico is jatropha. Jatropha is still in the very early stage of development and efforts appear to be focused on small scale plantations.

\section{Regional and Local Biofuels Resource Assessments}

The Institute of Electrical Investigations (IIE) estimated and mapped the biomass resources available by Basic Geostatistical Area (BGA). These are territorial divisions, smaller than the municipalities, developed by the National Institute for Statistics and Geography (INEGI) to collect statistics. The study assessed the amount of residues available in each BGA using cropto-residue ratio as well as their energy potential in GJ (Figure 22). The following six crops are considered: beans, corn, wheat, rice, barley, grain sorghum, and sugar cane. IIE has also estimated and mapped animal manure by BGA and its energy potential.

\section{Potencial Bioenergético de Desechos Agrícolas}

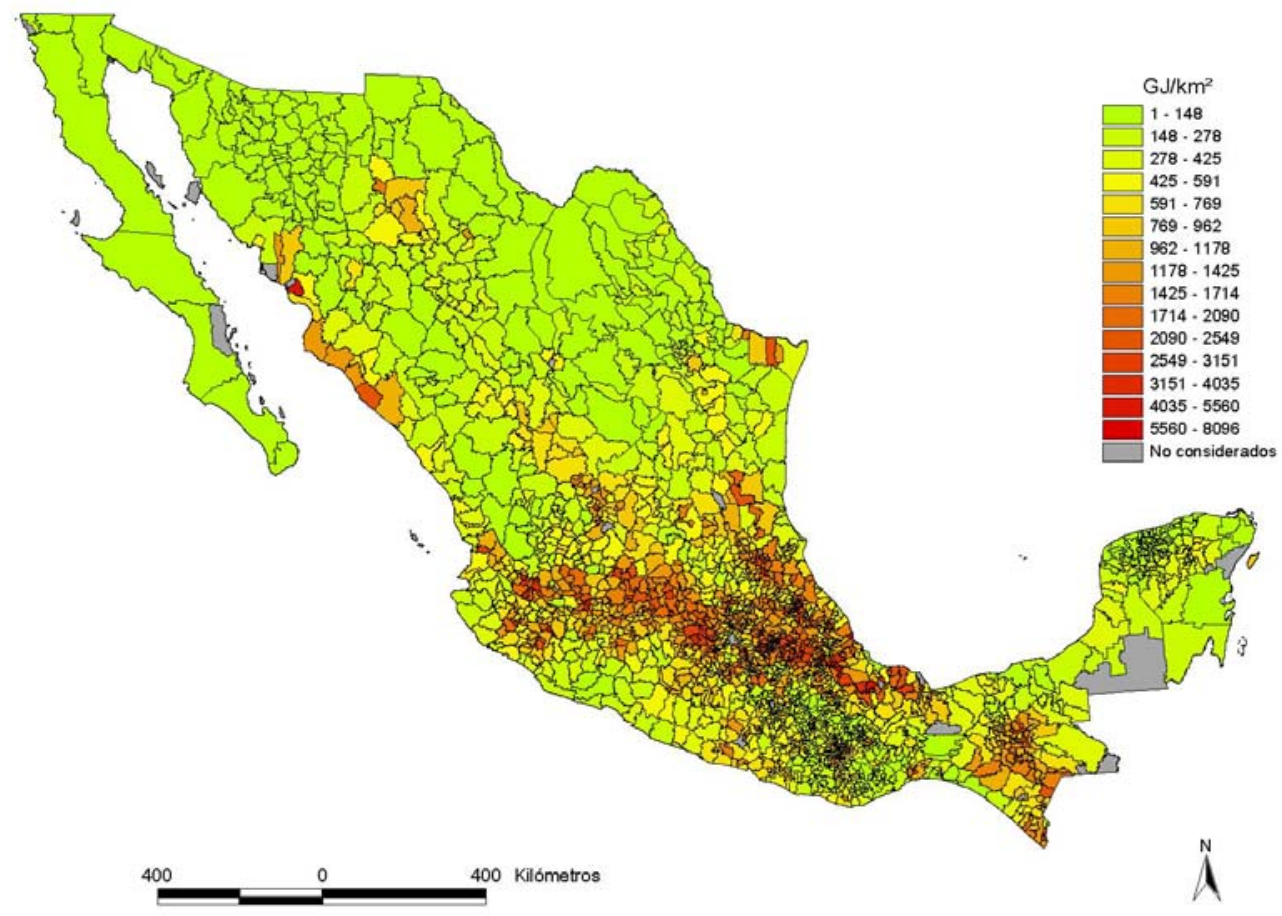

Figure 22. Energy Potential of Crop Residues in Mexico 


\section{Biomass Resource Assessment Capabilities}

It is clear from the examples above that Mexico has very good biomass resource assessment capabilities. The primary agencies providing expertise in agriculture and forestry include the National Forest Commission (CONAFOR); the Secretariat of Agriculture, Livestock, Rural Development, Fishes and Feeding (SAGARPA); and the Mexican National Institute of Forestry, Agriculture, and Livestock Research (INIFAP). Two other agencies analyze biomass resources as feedstock for power generation - the Institute of Electrical Investigations (IIE) and the Secretariat of Energy (SENER).

Integrated Techniques. GIS and RS have been used by all agencies listed above for mapping cropland areas and monitoring crop production. Additionally, the National Autonomous University of Mexico (UNAM)'s Center for Ecosystems Research has been working in the field of forestry resources using geospatial techniques. UNAM conducted a wood-fuel supply and demand spatial analysis to identify high-priority (or hot spot) areas where actions to ensure the sustainability of fuelwood use are urgently needed. The approach used in the Woodfuel Integrated Supply/Demand Overview Mapping (WISDOM) model is illustrated in Figure 23.

\section{Selection of the spatial base}

2. DEMAND module

- Woodfuel consumption by type, area, user, etc.

- Urban/rural population

- Population growth

- Urbanisation

- Socio-economic data (cultural/income groups)

- ......

- Local surveys

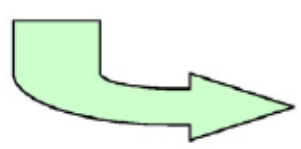

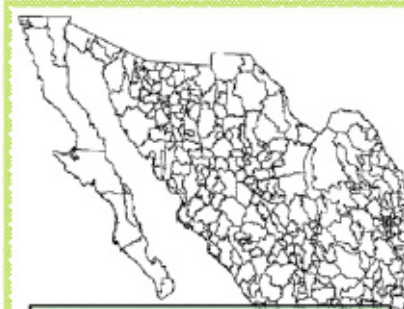

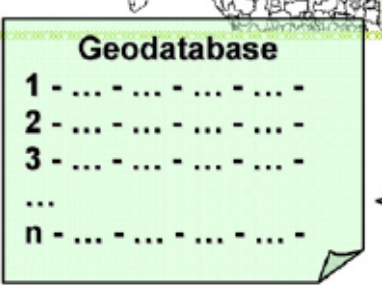

4. INTEGRATION module

- Woodfuel deficit areas

- Woodfuel surplus areas

- Local pressure on woodfuel sources

- Sustainability indexes

- ......

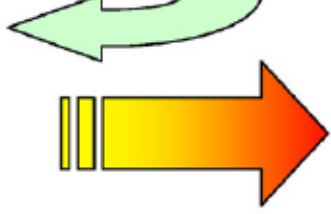

\section{SUPPLY module}

- LU/LC change

- Woody biomass by LU/LC

- Woodfuel Productivity

- Accessibility

- Wood industries' by-products

- .......

- Local surveys

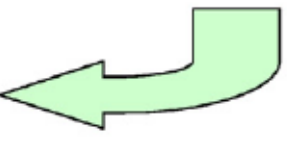

5. Priority areas

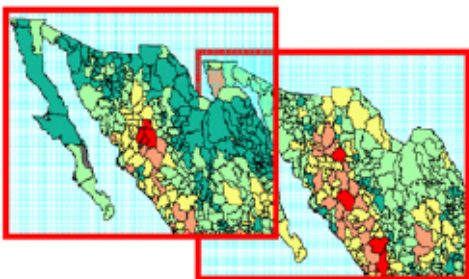

Source: Ghilardi, A., et al. 2007

Figure 23. WISDOM Analysis Steps 
As noted in Figure 23, the WISDOM approach combines geospatial techniques and sample surveys. A combination of different methods has been used by the INIFAP in crop yield prediction and by SAGARPA for collecting crop information. INIFAP uses a set of simulation models with input data taken on-site at sample plots as well as remotely sensed data. The different levels of government agencies - federal, state and municipal - are already benefiting from timely information on the condition of agricultural crops, including the relationship with climatic effects and other potentially adverse factors as well as the impact on crop production. SAGARPA collects agricultural information via sample ground and paper surveys as well as remote sensing. The study by CENER-BID-GTZ conducted an economic analysis using numeric modeling to estimate the cost of producing ethanol and biodiesel from different feedstock.

Data Availability. SAGARPA and Mexico State's Institute of Agriculture, Livestock, Water, and Forestry Research and Training (ICAMEX) provide crop and livestock statistics by state, district and municipality. Additionally, the National Institute for Statistics and Geography (INEGI) provides agricultural and forestry statistics at the BGA level, collected via paper surveys.

\section{References}

1. Arita, G. and Galarza, J. M, Centro de Estadistica Agropecuaria, SAGARPA, Remote Sensing in Mexico: An Application in the Agricultural Sector, 2000 (Secured)

2. Comisión Nacional Forestal (CONAFOR) y la Asociación Nacional de Energía Solar (ANES), La Bioenergia En Mexico: Un Catalizador Del Desarrollo Sustentable, 2006

3. Feregrino, Alma Santa Rita, Secretaria de Energia (SENER), Biocombustibles: Perspectivas del Desarrollo en Mexico, Presentation at the Second Latin American and the Caribbean Biofuels Seminar, El Salvador, September 2007, http://www.olade.org/biocombustibles/Documents/ponencias/día3/Sesión12Dia\%203/AlmaSantaRita.pdf

4. Ghilardi, A. et al (2007), "Spatial analysis of residential fuelwood supply and demand patterns in Mexico using the WISDOM approach", Biomass \& Bioenergy (31):475-481

5. Institute of Agriculture, Livestock, Water, and Forestry Research and Training (ICAMEX), Accessed April 2008, http://www1.edomexico.gob.mx

6. Instituto de Investigaciones Eléctricas (IIE), Sistema de Información Geográfica para las Energías Renovables (SIGER), Accessed May 2008, http://genc.iie.org. $\mathrm{mx} /$ genc/siger/frames. asp? mcontador=18290\&val=4\&url=mapas $1 \% 2 \mathrm{E}$ htm

7. Instituto Nacional de Estadística Geografía e Informática (INEGI), Accessed April 2008, http://www.inegi.gob.mx/inegi/default.aspx

8. Secretariat of Agriculture, Livestock, Rural Development, Fishes and Feeding (SAGARPA), Accessed April 2008, http://www.sagarpa.gob.mx/

9. Secretaría de Energía (SENER), Banco Interamericano de Desarrollo (BID), and Deutsche Gesellschaft für Technische Zusammenarbeit (GTZ), Potenciales y Viabilidad 
del Uso de Bioetanol y Biodiesel para el Transporte en México, 2006, http://www.sener.gob.mx/webSener/res/169/Biocombustibles en Mexixo Estudio Com pleto.pdf

10. Soria-Ruiz, J. and Fernandez-Ordonez, Y., INIFAP, Crop Monitoring and Crop Yield Prediction Computerized Tools in Mexico, Presented at the Computers in Agriculture and Natural Resources, 4th World Congress Conference, Orlando, Florida, July 2006, http://asae. frymulti.com/abstract.asp?aid $=21854 \& \mathrm{t}=2$ 


\section{New Zealand}

\section{Economy-Wide Biofuels Resource Assessments}

A comprehensive biomass resource assessment was completed at an economy-wide and regional level by the New Zealand Crown Research Institute Scion (formerly known as Forest Research) in 2007. The project examined crops and crop residues; woody biomass (logging residues, wood processing residues, horticultural prunings, and short rotation forestry); municipal and industrial wastes (sewage bio-solid effluents; solid waste; animal manures; and industrial wastes from dairy, fruit, vegetable, and meat processing); and algae. A summary of the findings is presented below.

\section{First-Generation Biofuels Potential}

Ethanol: New Zealand produces ethanol from whey, a byproduct of the dairy industry and it is estimated that the production will increase (USDA 2007). Ethanol produced from whey amounts to about 15 million liters per year, which meets $0.3 \%$ of the economy's gasoline needs and $0.2 \%$ of crude oil imports.

New Zealand has about 109,900 ha of grain crops planted: approximately 20,600 ha of corn (predominantly in the Waikato/Central North Island), 39,400 ha of wheat and 49,900 ha of barley (predominantly in Canterbury). However, the use of these grains for energy production is likely to lead to competition with food uses. The Scion study states that there are about 915,950 ha of pasture land that could physically and economically (based on current gross marginal returns in dollars per ha) be switched to grain for ethanol production if demand for the resource increases sufficiently. This area of land could potentially produce enough corn to make 4,100 million liters of ethanol ( $40 \%$ of current total liquid fuels demand). However, the net carbon balances would need to be examined in light of the value of pastureland as a carbon store.

Sugar crops (cane and beet) are not currently grown in New Zealand. However, sugar beet can be produced in Tasmania (Australia), where similar growing conditions exist. Successful sugar beet trials were undertaken in Southland, but the economics did not support development.

Biodiesel: Biodiesel feedstocks in New Zealand include used cooking oil and tallow. Scion reports that about 5-6 million liters of used cooking oil is generated per year, largely sourced 
from major population centers. New Zealand produces sufficient tallow (a by-product of the meat industry) to produce 132,000 tonnes of biodiesel per year, which could replace $7.6 \%$ of the economy's current diesel consumption and $2.9 \%$ of its crude oil imports.

Rapeseed has been targeted as another source of biodiesel in New Zealand. Farmers in South Canterbury are being encouraged to grow the crop, supplying a biodiesel production plant with a target capacity of 70 million liters of biodiesel per year by 2011. The land area required to meet this level of production would be around 50-55,000 ha, in a region that has more than 100,000 ha of arable cropland. Some competition with land for growing food crops and animal grazing is inevitable if the stated levels of production are to be achieved. However, the use of the residual cake from the processed oil seed can be used as a stock food. This largely offsets the loss of grazing area.

\section{Second-Generation Biofuels Potential}

Ethanol: The Scion study estimated that about 5.5 Mt of crop and woody residues are available annually in New Zealand as illustrated in Table 22. These second-generation feedstocks could yield about $1.7 \mathrm{hm}^{3}$ of ethanol or $0.8 \mathrm{Mt}$ gasoline equivalent per annum. Such a volume could displace $34 \%$ of current gasoline consumption and $18 \%$ of crude oil imports.

Table 22. Lignocellulosic Biomass Available in New Zealand, 2005-2010

\begin{tabular}{|l|r|}
\hline \multicolumn{1}{|c|}{ Residues } & \multicolumn{1}{c|}{$\begin{array}{c}\text { Quantity } \\
\text { (dry tonnes) }\end{array}$} \\
\hline Logging & $3,600,000$ \\
\hline Primary Mill & 800,000 \\
\hline Horticultural Wood & 46,000 \\
\hline Municipal Wood & 500,000 \\
\hline Crop & 500,000 \\
\hline Total & $\mathbf{5 , 4 4 6 , 0 0 0}$ \\
\hline
\end{tabular}

Source: Scion, 2007; Note that logging residue availability

will increase over time as the harvest of plantation forest increases in the next 20 years

Fast-growing tree species such as eucalyptus, acacia and willow have potential as dedicated energy crops for New Zealand. Currently, these short-rotation forestry (SRF) crops are not commercially used for bioenergy production, with a small area ( $<20 \mathrm{ha}$ ) established as trials. Some expansion of the willow SRF resource is planned for the Lake Taupo area, with the development of a 20 ha nursery to provide planting stock for a planned 1,200-1,500 ha planting program in 2009. The study states that it is unlikely that there will be any commercial SRF 
harvesting operations in New Zealand in the next 3 years because there is currently no resource to harvest.

Biodiesel: Second-generation biodiesel feedstock considered in New Zealand is algae. Algal biomass is not produced commercially; however, existing municipal waste streams offer significant potential and this route is being actively researched by government and private organizations, with research on growth and conversion underway. As shown in Table 23, wastewater and poultry waste could provide as much as 1,787 dry tons of algae per day or 652,000 tonnes per year. This amount would yield about 125,000 - 326,000 tonnes of oil, considering that oil yield is between 0.2 - 0.5 tonne per tonne of algae (NREL 2008).

Table 23. Algae Potential from Existing Waste Streams in New Zealand

\begin{tabular}{l|l}
$\begin{array}{l}\text { Municipal } \\
\text { wastewater: }\end{array}$ & $\begin{array}{l}\text { The potential daily algal biomass yield from each existing WSP in New Zealand was calculated } \\
\text { from wastewater flow data to give a total of } 41 \text { tonnes per day (dry weight). By converting all } \\
\text { existing WSP in New Zealand to HRAP the potential daily algal biomass yield could increase to } \\
164 \text { tonnes dry weight/day. If all municipal wastewater was treated in HRAP with addition, the } \\
\text { potential daily algal biomass yield could be further increased to } 475 \text { tonnes dry weight/day. }\end{array}$ \\
Dairy farm & $\begin{array}{l}\text { The daily al gae production potential from dairy farm wastewater in NZ using HRAP with } \mathrm{CO}_{2} \\
\text { addition would be } 1093 \text { tonnes dry weight/day. This is more than double that which could be } \\
\text { produced from all municipal wastewater, however, with the production spread over many farms, } \\
\text { cost-effective small-scale harvesting and processing technology will be required to realise this } \\
\text { potential. }\end{array}$ \\
Pig farm wastewater: & $\begin{array}{l}\text { There are approximately } 250 \text { commercial pig farms in New Zealand, each with an average of } \\
1000 \text { pigs. As all of the daily manure production is treated, the daily algae production potential } \\
\text { from piggery wastewater in NZ using HRAP with } \mathrm{CO}_{2} \text { addition would be } 83 \text { tonnes dry weight/ } \\
\text { day. The high and concentrated wastewater flows of commercial piggeries compared to those of } \\
\text { the largest dairy farms makes piggeries attractive potential sites for algae biomass production. }\end{array}$ \\
Poultry waste: & $\begin{array}{l}\text { Poultry farming is gaining popularity in New Zealand with approximately } 350 \text { laying hen and } \\
\text { broiler chicken farms with a total of } 24 \text { million chickens. The daily algae production potential } \\
\text { from chicken farm manure in NZ using } \mathrm{HRAP} \text { with } \mathrm{CO}_{2} \text { addition would be } 136 \text { tonnes dry weight/ } \\
\text { day. However, as most poultry farms have solid manure collection systems, often with 100\% } \\
\text { export of the manure, the potential for algae production may be harder to realise that for other } \\
\text { agricultural manures. }\end{array}$
\end{tabular}

Source: Scion, 2007

\section{Regional Biomass Resource Assessments}

The Scion study used GIS to assess the lignocellulosic biomass at a regional level. Figure 24 illustrates an example of the series of maps presented in the report, and Table 24 shows the results in a tabular format, for the case of primary mill residues. Other types of residues considered at regional level, for which data are also provided in the study, include logging residues, municipal wood waste, horticultural wood residues, crop residues, fruit, and vegetable residues. 
Table 24. Regional Production and Use of Primary Mill Residues in New Zealand

\begin{tabular}{|c|c|c|c|}
\hline \multicolumn{4}{|c|}{ Based on processing 13.9 million $\mathrm{m}^{3}$ roundwood } \\
\hline Wood supply region & Residue production & $\begin{array}{l}\text { Estimated residue } \\
\text { used as bioenergy }\end{array}$ & Residues available \\
\hline Northland & 288 & 288 & 0 \\
\hline Auckland & 256 & 91 & 164 \\
\hline $\mathrm{CNI}$ & 2,139 & 1,508 & 631 \\
\hline East Coast/Hawke's Bay & 373 & 299 & 74 \\
\hline $\mathrm{SNI}$ & 267 & 130 & 137 \\
\hline Nelson/Marlborough & 316 & 357 & -41 \\
\hline West Coast & 73 & 69 & 4 \\
\hline Canterbury & 149 & 83 & 66 \\
\hline Otago/Southland & 263 & 241 & 23 \\
\hline Total & 4,123 & 3,066 & 1,099 \\
\hline Existing markets & & $\begin{array}{l}\text { Estimated } \\
\text { residue used }\end{array}$ & \\
\hline Wood pellets & & 200 & \\
\hline Landscaping and other uses & & 100 & \\
\hline Estimate of residue available & & & 799 \\
\hline
\end{tabular}

Source: Scion, 2007

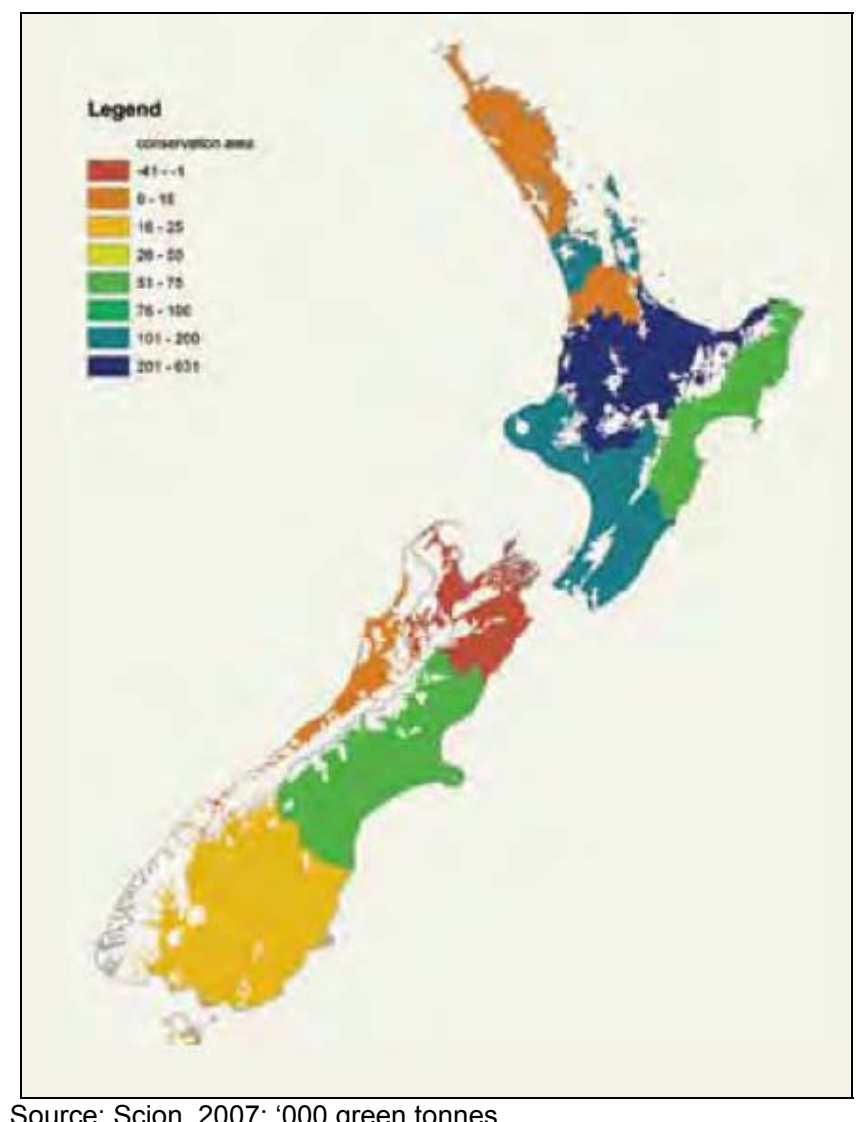

Source: Scion, 2007; ‘000 green tonnes

Figure 24. Primary Mill Residues in New Zealand by Region, 2005 


\section{Biomass Resource Assessment Capabilities}

New Zealand has very good biomass resource assessment capabilities. Leading agencies include the New Zealand Crown Research Institutes' Scion and AgResearch; Landcare Research, Crop \& Food Research; the Ministry of Agriculture and Forestry (MAF); the Energy Efficiency and Conservation Authority (EECA); and Massey University.

Geospatial techniques and GIS, in particular, have been used by Scion, Landcare Research, and MAF to map agricultural and forestry products and residues. A GIS model for estimating potential volumes and costs for delivering forest derived biomass to a chosen site has been developed. A forest productivity database has also been developed in a geospatial format.

Modeling. Numeric modeling has been used by MAF in crop, forest industry, and wood availability forecasts. Bioenergy researchers at Scion have developed a range of user-friendly calculation tools (based on numeric modeling) to assess wood waste, cost of recovery, transportation costs, $\mathrm{CO}_{2}$ emissions, and return on investment to support decisions relating to bioenergy. More information about these tools is available at http://www.scionresearch.com/BKC/index.html.

Data Availability. Two agencies are responsible for collecting and reporting crop, livestock, and forestry statistics in New Zealand - the MAF and Statistics New Zealand (SNZ). Both agencies use a combination of data-collection methods - paper and ground sample surveys. Information is collected at the farm or processing facility; aggregated; and reported by territory, region or nationwide.

\section{References}

1. AgResearch, Accessed may 2008, http://www.agresearch.co.nz/

2. Crop and Food Research, Accessed April 2008, http://www.crop.cri.nz

3. Energy Efficiency and Conservation Authority (EECA), Forest Residue Harvesting for Bioenergy Fuels, May 2008, http://www.bkc.co.nz/BioenergyResources/Reportsandpublications/tabid/87/Default.aspx

4. Landcare Research, Accessed April 2008, http://www.landcareresearch.co.nz

5. Ministry of Agriculture and Forestry (MAF), Accessed May 2008, http://www.maf.govt.nz

6. National Institute of Water \& Atmospheric Research (NIWA), Accessed April 2008, http://www.niwa.cri.nz/

7. Scion, Accessed may 2008, http://www.scionresearch.com/

8. Scion, Bioenergy Options for New Zealand, Situation Analysis: Biomass Resources and Conversion Technologies, November 2007, http://www.scionresearch.com/Portals/0/SCIONBioenergyOptionsReport.pdf 
9. Statistics New Zealand, Accessed May 2008, http://www.stats.govt.nz/

10. USDA, Foreign Agricultural Service, New Zealand Bio-Fuels Policy, Production and Market Potential, February 2007,

http://www.fas.usda.gov/gainfiles/200702/146280233.pdf 


\section{Papua New Guinea}

\section{Economy-Wide Biofuels Resource Assessments}

\section{First-Generation Biofuels Potential}

Ethanol: Papua New Guinea (PNG) produces small amounts of sugar cane. Ramu Sugar Ltd (RSL) is a registered private enterprise, the only PNG company specializing in sugar cane production. Sugar cane is grown on 8,500 ha, with production at more than 500,000 tonnes in 2002 (NAIS 2006). The main by-product of the RSL sugar mill is molasses. About $12 \%$ of total output is sold locally, primarily as cattle feed. The balance of about 15,000 tonnes per year is pumped to the distillery adjacent to the sugar mill for conversion into alcohol. In 1995, the distillery was upgraded from producing industrial grade alcohol to producing potable grade alcohol. The bulk of the annual production of more than 2 million liters of potable alcohol is exported (Pacific Magazine 2003).

If $20 \%$ of PNG's sugar cane production is used for biofuels, it would yield about $0.06 \mathrm{hm}^{3}$ of ethanol per year $(29,000$ tonnes gasoline equivalent). This volume would displace $6.6 \%$ of the economy's crude oil import.

Biodiesel: There is no information on biodiesel production and consumption in PNG. However, there is a widespread use of straight vegetable oil (SVO) or mixture of SVO and petro-diesel. Domestic biodiesel feedstocks include palm and coconut oil. Oil palm has been a widely cultivated cash crop since the 1960s, and today it is the economy's leading agricultural export. PNG is the world's sixth-largest producer and the third-largest exporter of palm oil, behind Malaysia and Indonesia. Crude palm oil (CPO) production in 2007 was 380,000 tonnes, almost entirely for export. The coconut oil industry is relatively small (about 60,000 tonnes in 2007), of which 43,000 tonnes or $73 \%$ was exported (USDA 2008).

If $20 \%$ of PNG's current vegetable oil production is used for biofuels, it would yield about 82,000 tonnes of biodiesel. This volume would replace $48 \%$ of the economy's current diesel consumption and $19 \%$ of crude oil import. 


\section{Second-Generation Biofuels Potential}

No assessment of lignocellulosic biomass was identified during this survey. Considering PNG's agricultural and forestry industries a significant waste material could be available for ethanol production. These include logging, oil-palm and coconut residues, as well as sugar cane bagasse.

\section{Biomass Resource Assessment Capabilities}

Although some of the products mentioned below are not direct examples of biomass resource assessments, they are indicators of existing capabilities - methods, tools, scientific knowledge and data - that could be applied to future resource assessment projects.

Leading agencies and institutions providing expertise in agriculture and forestry include the National Agricultural Research Institute (NARI), Department of Agriculture and Livestock (DAL), PNG Forest Authority (PNGFA), Forest Industries Association (FIA), and PNG University of Technology (Department of Agriculture and Department of Forestry).

Geospatial techniques (GIS and RS) have been used by the University of Papua New Guinea (UPNG) and NARI in various projects. The UPNG Remote Sensing Center (in conjunction with the Australian National University) recently released a report on the state of forests in PNG (UPNG/ANU 2008). The study used satellite images and GIS to illustrate the loss in forest cover between 1972 and 2002 (Figure 25). It found that at current rates, 53\% of forest is at risk of being destroyed by 2021 . The study also found that even in conservation areas, trees have been logged or cut down by local subsistence farmers unabated. Papua New Guinea has the world's third-largest tropical forest but it was being cleared or degraded at a rate of 362,000 hectares (895,000 acres) a year. UPNG also developed a Resource Information System (PNGRIS), which is a computer-based inventory of PNG natural resources, land-use, and population information. The system provides a series of maps and data on climate, elevation, relief, geology, soil, population and inundation, useful for natural resource planning, development, and conservation. The Land Use Section in DAL uses PNGRIS in combination with other data to develop crop suitability maps. Additionally, NARI uses GIS to map crop production, land use, and socio-economic information related to farming systems. 


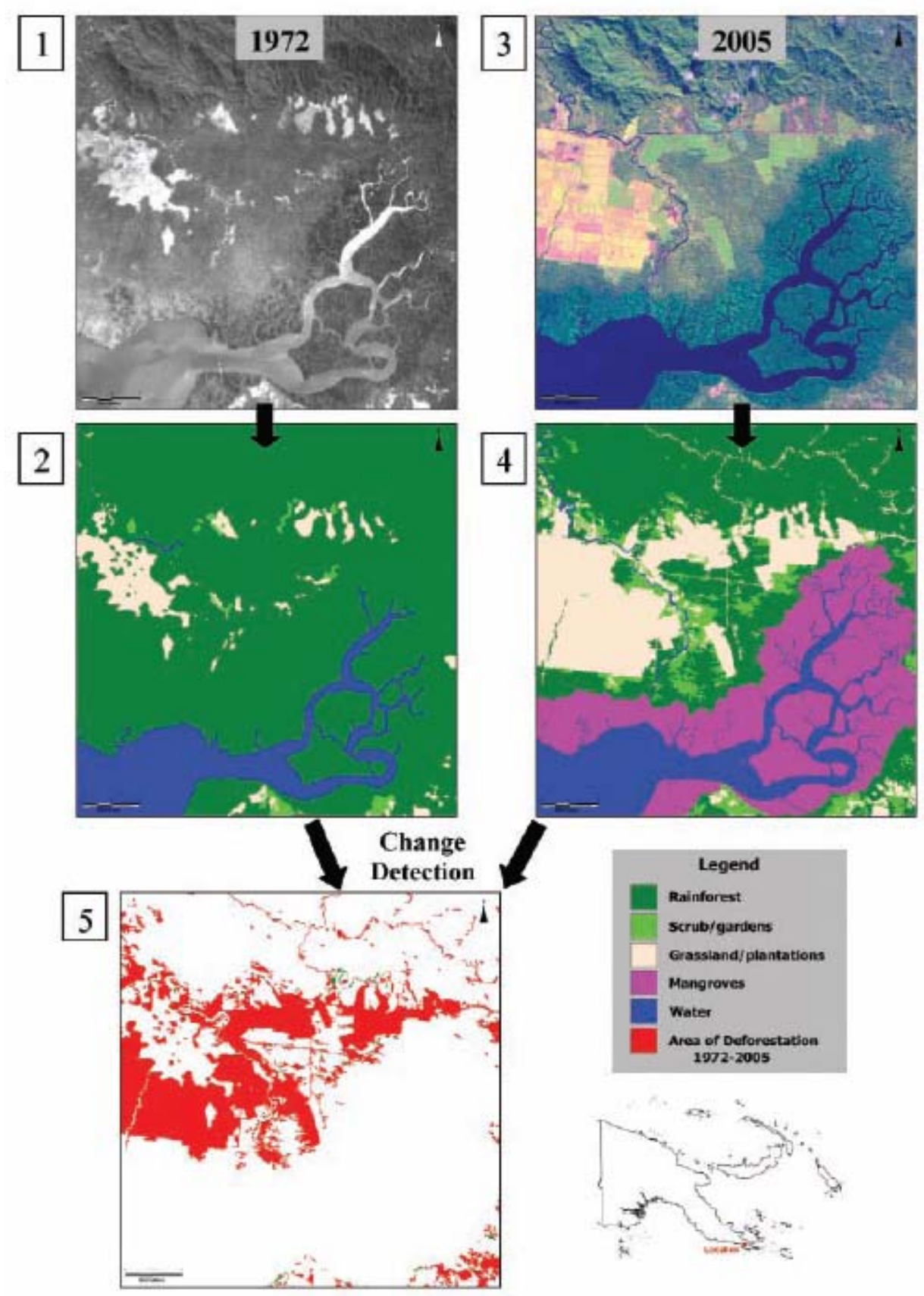

Source: UPNG/ANU, 2008

Figure 25. Estimating Area of Deforestation in Papua New Guinea

Data Availability. The survey didn't find any agricultural and forestry statistics by domestic agencies in electronic format. In most cases, this type of information is provided by FAO and the United States Department of Agriculture (USDA) at an economy-wide level via their Web sites. The Forest Authority (PNGFA) is the government body responsible for monitoring and 
controlling the wood- and forest-based industries and the management of forest resources. NARI is responsible for collection and maintenance of agricultural statistics. However, no data is provided via NARI and FA Web sites. Without this information, the survey found it difficult to assess data-collection methods and frequency, as well as geographic scale.

\section{References}

1. Department of Agriculture and Livestock, Accessed March 2008, http://www.agriculture.gov.pg/

2. FAO, Selected indicators of food and agriculture development in Asia-Pacific region 1992-2002, October 2003, http://www.fao.org/docrep/004/AD452E/ad452e00.HTM

3. Forest Authority (PNGFA), Accessed March 2008, http://www.forestry.gov.pg/

4. Forest Industries Association, Accessed march 2008, http://www.fiapng.com/

5. National Agricultural Information System (NAIS), Accessed March 2008, http://www.pngnais.org/wysiwyg/view page.php?id=13

6. National Agricultural Research Institute, Accessed March 2008, http://www.nari.org.pg/

7. National Statistical Office of Papua New Guinea, Accessed April 2008, http://www.nso.gov.pg/

8. Pacific Magazine, Ramu Sugar - Cattle Trade Doing Well, May 2003, http://www.pacificmagazine.net/issue/2003/05/01/ramu-sugar-cattle-trade-doing-well

9. United States Department of Agriculture (USDA), Data Provided by Index Mundi, Accessed March 2008, http://indexmundi.com/

10. University of Papua New Guinea (UPNG), Remote Sensing Center, Accessed April 2008, http://gis.mortonblacketer.com.au/upngis/

11. University of Papua New Guinea (UPNG), Papua New Guinea Resource Information System Handbook, Third Edition, June 2008, http://gis.mortonblacketer.com.au/upngis/Downloads/PNGRIS $\% 20 H a n d b o o k \% 203$ rd $\% 2$ OEdition.pdf

12. University of Papua New Guinea (UPNG) and Australian National University(ANU), The State of Forests of Papua New Guinea: Mapping the extent and condition of forest cover and measuring the drivers of forest change in the period 1972-2002, June 2008, http://www.scienceinpublic.com/State\%20of\%20Forests\%20of\%20PNG embargo\%20ve rsion.pdf 


\section{Peru}

\section{Economy-Wide Biofuels Resource Assessments}

\section{First-Generation Biofuels Potential}

Ethanol: Peru has a number of crops that can be used for ethanol production, including sugar cane, grain sorghum, corn, cassava, potatoes, and rice. The economy is particularly competitive in sugar cane, boasting the highest yield per hectare in the world. According to the Ministry of Agriculture (MINAG), the Peruvian sugar cane industry in 2006 produced 110 tonnes per ha compared to just 85 tonnes per ha in Brazil. Sugar cane production was $7.2 \mathrm{Mt}$ in 2006, with about $80 \%$ going to sugar production. The rest is used for production of alcohol used by the beverage, pharmaceutical, and chemical industries. Sugar cane production in Peru is cultivated in five regions along the coast and $77 \%$ of the production is concentrated in the North. The region La Libertad provided $46 \%$ of total production in 2006, followed by Lambayeque (23\%), Lima (22\%), Ancash (8\%), and Arequipa (1\%). Potential for expanded production of sugar cane and other crops remains to be assessed.

If $20 \%$ of Peru's current starch and sugar crops production could be spared for biofuels, it would yield about $1 \mathrm{hm}^{3}$ of ethanol or $0.48 \mathrm{Mt}$ gasoline equivalent per annum. This volume would be sufficient to replace $62 \%$ of Peru's current gasoline consumption and $10 \%$ of its crude oil imports.

Biodiesel: A study by the Soluciones Prácticas-ITDG in 2007 evaluated the resource potential for biodiesel in Peru. The study states that there are a variety of raw materials available vegetable oils, used cooking oil, fish oil, and animal fats; however, there is not sufficient quantity to satisfy a potential industry demand. Peru is a net vegetable oil importer with about $60 \%$ in 2002.

Primary feedstock for biodiesel production is palm oil. Production is concentrated in the provinces of Ucayali, San Martin, and Loreto. There are 21,200 ha planted with oil palm. Productivity varies between 1.7 and 5.7 tonnes of crude palm oil per ha. According to MINAG, approximately 1.4 million ha are available for capacity expansion. The National Institute of Natural Resources (INRENA) estimated that there are 4.8 million ha available, 510,000 (about 
$10 \%)$ of which are in non-forested areas. However, there is the emergence of concerns regarding the social and environmental impacts of expanding oil palm plantations in regions of high biodiversity.

Other feedstocks available in Peru include used cooking oil and fish oil. Used cooking oil could have interesting niche applications and environmental benefits; however, logistics of collection would be daunting. Peru is a large producer and exporter of fish oil, but there is little experience in using this oil as biodiesel feedstock worldwide.

There is a program to promote planting of canola on $20,000-200,000$ ha in the Peruvian highlands.

Table 25 summarizes the resources available for biodiesel production in Peru. If $20 \%$ of Peru's current palm oil production, as well as all waste oils and fats, were used for biofuels, it would yield about 303,000 tonnes of biodiesel per annum. This amount would replace $14 \%$ of Peru's current diesel consumption and $6 \%$ of its crude oil imports.

Table 25. Biodiesel Resources in Peru, 2005

\begin{tabular}{|l|r|}
\hline \multicolumn{1}{|c|}{ Resource } & $\begin{array}{c}\text { Quantity } \\
\text { (tonnes per year) }\end{array}$ \\
\hline Palm oil & 48,000 \\
\hline Used cooking oil & 3,680 \\
\hline Fish oil & 290,000 \\
\hline Total & 341,680 \\
\hline
\end{tabular}

\section{Second-Generation Biofuels Potential}

No assessment of lignocellulosic biomass was identified during this survey. Potential materials for ethanol production include sugar cane bagasse, crop residues, logging, and oil-palm residues. There are several plantation trails of jatropha in San Martin (Tarapoto) and Amazonas (Bagua Chica). 


\section{Biomass Resource Assessment Capabilities}

Peru appears to have good capabilities to conduct a detailed level of biomass resource assessments. Leading agencies with knowledgeable staff in agriculture and forestry are the MINAG and INRENA. These two institutions have been using GIS to map crop and forest resources. Additionally, INRENA has been using RS for forest monitoring. Figure 26 illustrates a geospatial tool developed by MINAG showing land use.

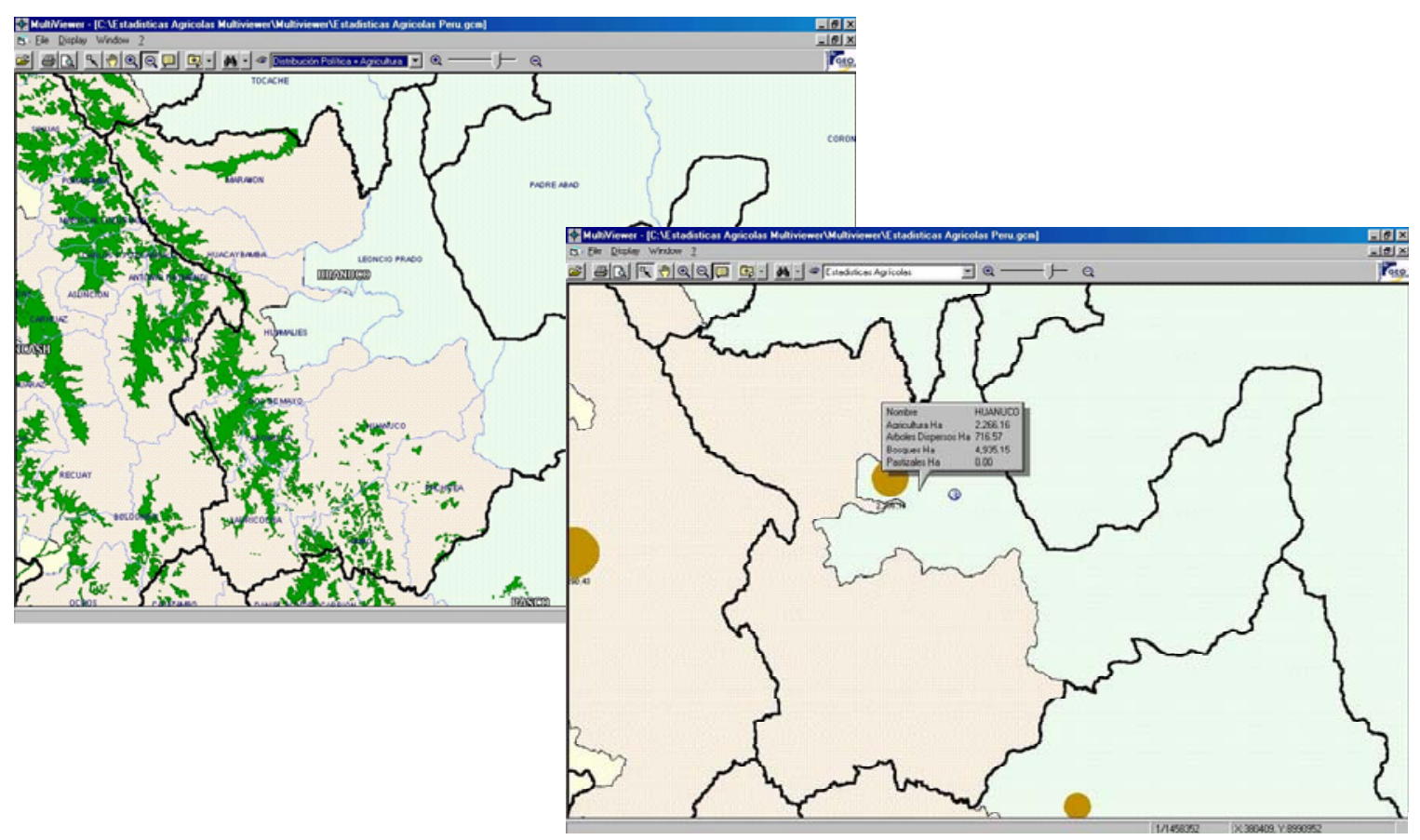

Source: MINAG, 2008

Figure 26. Atlas of Agricultural Lands in Peru

MINAG collects and provides monthly and annual statistics on crop production; acreages; and yield at an economy-wide, regional, provincial, and district level. Data is collected via sample paper and field surveys. INRENA manages forest resources and provides forest and timber product statistics annually at a regional level.

\section{References}

1. Castro, P., Opciones para la producción y uso del biodiésel en el Perú, Soluciones Prácticas - ITDG, August 2007

2. National Institute of Natural Resources (INRENA), Accessed April 2008, http://www.inrena.gob.pe 
3. Inter-American Development Bank (IADB), A Blueprint for Green Energy in the Americas, 2007, http://idbdocs.iadb.org/wsdocs/getdocument.aspx?docnum $=945758$

4. International Energy Agency (IEA), Country energy statistics, Oil in Peru, 2005, http://www.iea.org/Textbase/country/index.asp

5. Ministry of Agriculture (MINAG), Major Crops Production, Accessed April 2008, http://www.portalagrario.gob.pe/download/pdf/especiales/dinamica/lll Agricola.pdf

6. Ministry of Agriculture (MINAG), Geographic Information Systems, Accessed April 2008, http://www.portalagrario.gob.pe/sistema informacion.shtml

7. United States Department of Agriculture (USDA), Data Provided by Index Mundi, Accessed March 2008, http://indexmundi.com/ 


\section{The Philippines}

\section{Economy-Wide and Regional Biofuels Resource Assessments}

\section{First-Generation Biofuels Potential}

Ethanol: In the Philippines, sugar cane is considered a primary feedstock for ethanol production. The government sees it as the most reliable feedstock due to its well-established farming technologies and the highest yield per hectare compared to other feedstock (corn, cassava, and sweet sorghum). Sugarcane production in the Philippines is expected to increase to meet the requirements of the Biofuels Act. At present, the sugar industry can only supply $79 \%$ of the needs of the $5 \%$ ethanol blend. So the current area of 344,700 ha devoted to sugar cane would have to expand to meet ethanol demand. To produce 120,000 litres of ethanol daily, sugar cane plantations need 7,000 to 8,000 ha aside from the 10 to 20 ha for each ethanolprocessing plant. The Sugar Regulatory Administration (SRA) has already identified 237,748 ha of new sugar fields, mostly in Mindanao, that can be tapped to produce fuel ethanol (Bulatlat 2007).

Additional ethanol feedstocks considered in the Philippines are sweet sorghum and cassava. A study completed by the Department of Agriculture- Bureau of Agricultural Research (DA-BAR) and International Society for Southeast Asian Agricultural Sciences (ISSAAS) in 2007 evaluated the potential of sweet sorghum for ethanol production in the Philippines. It concluded that the crop is comparable with other types of feedstock in terms of yield, bioethanol productivity, and cost. The ethanol yield of sweet sorghum per hectare is comparable with corn and cassava but lower than sugar cane. However, in terms of bioethanol productivity (the ethanol yield per ton of feedstock), sweet sorghum is the most productive with a production of 425 liters/ha (50 liters per ton from stalk and 375 liters per ton from grains). The study also states that sweet sorghum is cost- competitive compared to molasses, corn, and cassava; and also with sugar cane for caneextracted alcohol, but not for grain-extracted alcohol.

Cassava has long been cultivated in the Philippines, planted predominantly in Mindanao (Bukidnon) and Eastern Visayas. The Bureau of Agricultural Statistics (BAS) reports very low yields, around 8 tonnes per ha per year. Tests done at the Leyte State University in Baybay, 
Leyte, have shown, however, that yields of 35 tonnes per ha can be achieved with new varieties that can produce 4,900-6,545 liters per ha per year of ethanol.

If the equivalent of $20 \%$ of the Philippines' current starch and sugar crops production could be used for biofuels, fro example through a mix of increased grain yields and dedicated sugar cane plantations, it would yield about $0.33 \mathrm{hm}^{3}$ of ethanol or $0.16 \mathrm{Mt}$ gasoline equivalent per annum. This volume would replace $4 \%$ of the Philippines' current gasoline consumption and $1.5 \%$ of its crude oil imports.

Biodiesel: Primary feedstock for biodiesel production in the Philippines is coconut oil. The Philippines is one of the largest producers of coconut oil in the world, netting some 1.5 million tonnes per year. About $20 \%$ of this production is used for domestic consumption while the balance of $80 \%$ is exported. Mindanao accounts for almost $60 \%$ of the economy's total coconut oil production. If $20 \%$ of the Philippines' coconut oil production were used for biofuels, it would yield about $0.31 \mathrm{Mt}$ of biodiesel per year. This would be sufficient to displace $7 \%$ of the economy's 2005 diesel consumption and $3 \%$ of its crude oil imports.

\section{Second-Generation Biofuels Potential}

Ethanol: A biomass resource assessment study was conducted in 2000 by the University of the Philippines - Biomass Energy Laboratory in collaboration with the National Renewable Energy Laboratory of the U.S. Department of Energy (Biomass Atlas of the Philippines 2000). Six biomass resources were evaluated and mapped at an economy-wide, regional, provincial, and municipal level, in some cases. These resources include: rice hull, bagasse, coconut residues, animal manure, forestry wastes, and urban refuse. The assessment is based on statistical analysis of reported information, applying product-to-residue ratios. The study uses GIS and GPS technologies to generate a series of maps illustrating each biomass feedstock potential at different administrative levels, as shown in the example in Figure 27. Table 26 provides a summary of the lignocellulosic biomass resources in the Philippines, totaling about $17.7 \mathrm{Mt}$ in 1999. These crop, logging, and coconut residues, along with sugar cane bagasse, would yield $5.4 \mathrm{hm}^{3}$ of ethanol or $2.6 \mathrm{Mt}$ gasoline equivalent per annum. This volume would be sufficient to replace $63 \%$ of the economy's current gasoline consumption and $24 \%$ of its crude oil imports. 


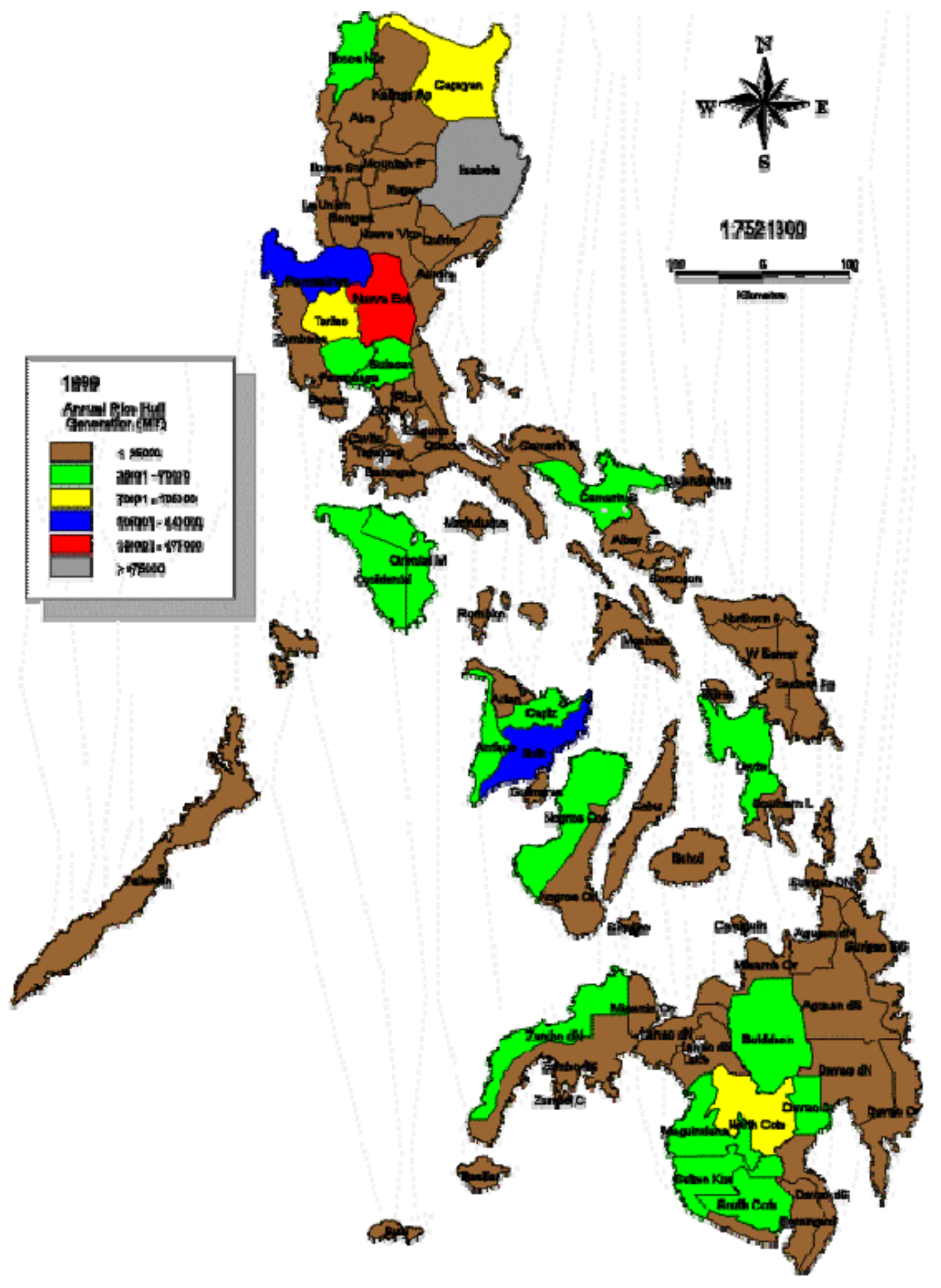

Source: Biomass Atlas of the Philippines, 2000

Figure 27. Annual Rice Hull Production by Province in the Philippines, 1999 
Table 26. Lignocellulosic Biomass Resources in the Philippines, 2000

\begin{tabular}{|c|c|}
\hline Biomass Resources & $\begin{array}{c}\text { Annual } \\
\text { Generation } \\
\text { (tonnes) }\end{array}$ \\
\hline Rice hull & $2,357,325$ \\
\hline Coconut shell & $1,948,867$ \\
\hline Coconut coir & $3,031,570$ \\
\hline Coconut husk & $4,330,814$ \\
\hline Bagasse & $5,985,840$ \\
\hline Logging residues* & 75,000 \\
\hline Total & $17,729,416$ \\
\hline
\end{tabular}

Source: Biomass Atlas of the Philippines, 2000; * Logging residues include damaged wood, tops and branches, stumps abandoned logs, and butt trimmings. Total logging residues are estimated at 104,450 cubic meters or 75,000 tonnes (assuming 1 metric ton $=1.4$ cubic meters).

Napier grass (Pennisetum purpureum) is one of the few dedicated energy crops being examined for biomass production in the Philippines. According to a study completed in 2001 (Samson et al.), productivity levels of 20 tonnes per ha could be achieved. If 100,000 ha were planted (representing a land area of about $4 \%$ of the maize acreage) about $2 \mathrm{Mt}$ of biomass could be produced. This is about seven times the available biomass that could be supplied from sugar cane trash if harvesting occurs only after the final ratoon crop. A ratoon crop is the new cane that grows from the stubble left behind are harvesting. It enables farmers to get three or four more crop harvests before they have to replant.

Biodiesel: Potential biodiesel feedstock in the Philippines is jatropha. The Department of Science and Technology (DOST) has identified about 2 million ha of unproductive and idle land nationwide suitable for jatropha cultivation. If farmers plant in field boundaries and hedges, or practice intercropping, 5 million ha could be available, producing $25 \mathrm{Mt}$ of biodiesel feedstock. This would be sufficient to displace the economy's current diesel consumption of $4.2 \mathrm{Mt}$ per annum several times over. A total of 360 ha are planted with jatropha in the Philippines: 200 ha in General Santos; 27 ha in Camarines Sur; 120 ha in Fort Magsaysay, Nueva Ecija; 5 ha in 
Dacong Cogon, Negros Occidental; and small plantations in Quezon Province (Philippines Department of Agriculture 2008).

\section{Biomass Resource Assessment Capabilities}

Geospatial technologies have been used by the National Mapping and Resource Information Authority (NAMRIA), an agency of the government under DENR. It is responsible for providing geospatial services and acting as the central mapping agency, depository, and distribution facility of natural resources data in the form of maps, charts, texts, and statistics.

Data Availability. The Biomass Energy Laboratory at University of the Philippines at Los Baños (UPLB) has been compiling biomass resource data since its establishment in 1997. The laboratory was established by the Department of Energy, Non-Conventional Energy Division, and biomass resource assessment is one of its major tasks. A list of other agencies providing data and expertise related to agriculture and forestry is provided below:

- The Department of Agriculture (DA) provides expertise and statistics on agricultural production and trade

- The Forest Management Bureau (FMB) of the Department of Environment and Natural Resources (DENR) provides forestry expertise and annual statistics (since 1990) by region and province; data is collected through sample field survey

- Department of Science and Technology (DOST) - Council for Agriculture, Forestry and Natural Resources Research and Development (PCARRD) and Forest Products Research and Development Institute (FPRDI)

- The National Statistics Office (NSO) provides an accurate estimate of the acreage of the major commodities at a municipal level; data is collected through sample paper surveys

- The Bureau of Agricultural Statistics (BAS) provides annual production data for major commodities; data is collected through sample paper surveys

- The National Food Authority (NFA) updates data on rice mills and their capacities

- The Sugar Regulatory Administration (SRA) reports sugar cane production and wastes data including operational sugar mills

- The United Coconut Association of the Philippines provides annual data on coconut production, coconut oil mills, and oil trade 


\section{References}

1. University of the Philippines at Los Baños (UPLB) Biomass Energy Laboratory - USAIDNREL, Los Baños, Biomass Atlas of the Philippines, 2000

2. Bulatlat, The Philippines alternative weekly magazine, Vol. VII, No. 3, February 2007, http://www.bulatlat.com/news/7-3/7-3-biofuels.htm

3. Bureau of Agricultural Research (BAR), Biofuels Feedstock, accessed March 2008, http://www.bar.gov.ph/downloadables/2008/biofuels/Biofuels\%20Feedstock.pdf

4. Capareda, S.C., Overend, R.P., The use of global positioning system (GPS) to estimate point sources of selected biomass residues in the Philippines, 2000

5. Department of Agriculture, Biodiesel Program, accessed April 2008, http://www.da.gov.ph

6. Department of Agriculture- Bureau of Agricultural Research (DA-BAR) and International Society for Southeast Asian Agricultural Sciences (ISSAAS), Feasibility Study for an Integrated Anhydrous Alcohol Production Plant Using Sweet Sorghum as Feedstock, Los Baños, 2007, http://www.bar.gov.ph/downloadables/2008/biofuels/Feasibility $\% 20$ Study $\% 20$ of $\% 20$ Swe et\%20Sorghum.pdf

7. Elauria, J.C., et al., "Assessment of sustainable energy potential of non-plantation biomass resources in the Philippines." Biomass and Bioenergy, 2005 29: 191-198.

8. International Energy Agency (IEA), Country energy statistics, Oil in the Philippines, 2005. http://www.iea.org/Textbase/country/index.asp

9. Samson, R., et al., Strategies for Enhancing Biomass Energy Utilization in the

Philippines, NREL, REAP - Canada, UPLB, 2001, http://www.reap-

canada.com/online library/Reports\%20and\%20Newsletters/International\%20Developme nt $/ 7 \% 20$ Strategies $\% 20 f o r . p d f$ 


\section{Russia}

\section{Economy-Wide Biofuels Resource Assessments}

No comprehensive biomass resource assessment was identified during this survey. The results below are a compilation of government officials' speeches, foreign agencies' analyses, and economy-wide statistics.

\section{First-Generation Biofuels Potential}

Ethanol: Russia is one of the world's largest producer and exporter of grains, particularly wheat, barley, rye, oats, and corn. Russia produced about $82 \mathrm{Mt}$ of grains in 2007 of which it exported 13.6 Mt (predominately wheat). An additional feedstock for ethanol production in Russia is sugar beet molasses. The economy produced about $29 \mathrm{Mt}$ of sugar beet in 2007 and is among the top five producers in the world. If the equivalent of $20 \%$ of Russia's current starch and sugar crop production could be spared for biofuels production as crop yields improve over time, about $5 \mathrm{hm}^{3}$ of ethanol or $2.3 \mathrm{Mt}$ gasoline equivalent could be refined per annum, enough to replace $9 \%$ of Russia's current gasoline consumption.

Biodiesel: Russia is also a major producer and exporter (mostly to the EU) of vegetable oils from sunflower, rapeseed, and soybean. In 2007, Russia produced about $2.4 \mathrm{Mt}$ of vegetable oils, predominately sunflower, and exported 450,000 tonnes (USDA 2008). If $20 \%$ of this vegetable oil production were devoted to biofuels, it would yield $0.5 \mathrm{Mt}$ of biodiesel yearly. This could replace $3.7 \%$ of the economy's current diesel consumption.

\section{Second-Generation Biofuels Potential}

Considering the scale of Russia's agricultural and forestry industries, a large amount of waste material exists for ethanol production including residues from crop production, logging, wood processing, and pulp and paper mill industries. The Russian Biofuels Association reports that about $100 \mathrm{Mt}$ of crop and wood residues are available in Russia annually (Ablaev 2008), which would yield about $30 \mathrm{hm}^{3}$ of ethanol or $14.4 \mathrm{Mt}$ gasoline equivalent. This volume would be sufficient to replace $55 \%$ of Russia's current gasoline consumption. 
During a televised conversation with Russians in October 2007, Prime Minister Vladimir Putin mentioned that for the production of bioenergy, Russia would use its land not suitable for the production of food crops, that is the vast taiga and tundra, where a range of productive herbaceous and woody biomass crops can be grown (Check Biotech 2007). The International Institute for Applied Systems Analysis (IIASA) assessed the land suitable for energy crops production (miscanthus, willow and poplar species), outside forest, urban areas and land highly suitable for cereals in Russia. However, the analysis doesn't quantity these resources (Fischer et al. 2005).

\section{Biomass Resource Assessment Capabilities}

Russia has very good capabilities - GIS/RS, significant scientific and engineering staff capacity in the forestry and agricultural sector, and extensive statistical information to conduct comprehensive biomass resource assessments.

Geospatial Capabilities. The Russian Academy of Sciences, in collaboration with the International Institute for Applied Systems Analysis (IIASA), completed two geospatial products containing a series of maps and tables on forestry and agricultural resources: Russian Forestry Analysis and Land Resources of Russia. Figure 28 illustrates two examples of these products. More information about these products can be found at http://www.iiasa.ac.at/Research/FOR/.

The Space Research Institute (SRI) of the Russian Academy of Science provides expertise in remote sensing. In collaboration with the Center for Forest Ecology and Productivity and a number of other leading research institutions, the SRI has a number of methodological and technological developments aimed at providing reliable and regularly updated information on the status and dynamics of Russian forests (FAO 2007). RS and GIS have been used by several leading Russian research institutions under the leadership of the Global Forest Watch, and in collaboration with the World Resource Institute, to develop an Atlas of Russia's Intact Forest Landscapes. More information about the atlas can be found at http://archive. wri.org/publication detail.cfm?pubid=3717.

The Federal Forestry Agency has also been using RS for forest monitoring. 


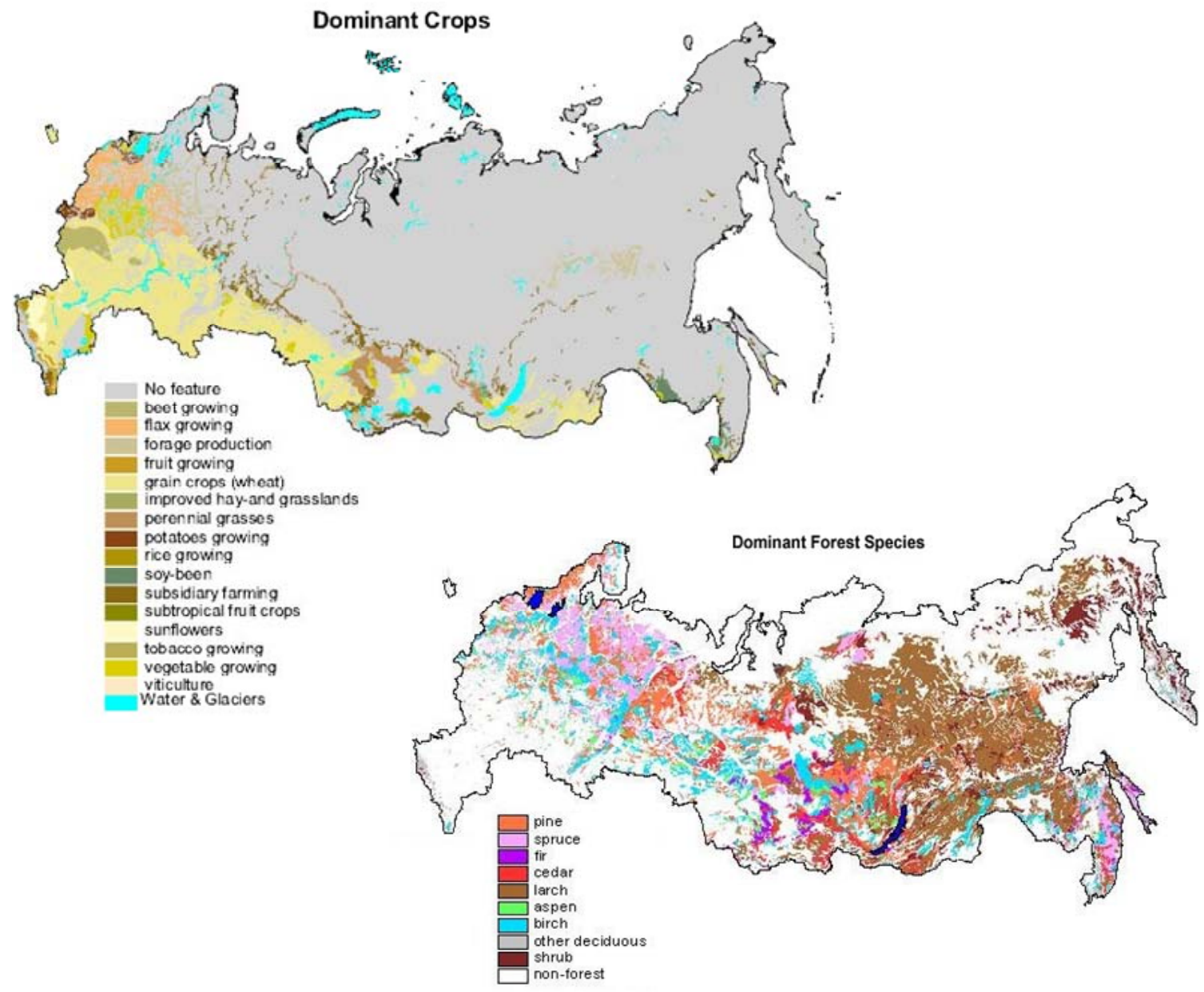

Source: IIASA/RAS, 2002

Figure 28. Maps of Crops and Forest Resources in Russia

Modeling. Moscow State Forest University (MSFU) is a major educational and scientific center related to the forest industry in Russia. Researchers at the university, in collaboration with IIASA, have developed models to simulate forest ecosystem dynamics and to assess biological productivity of forests. These models could be used in different ecological applications, in forest inventory, and forest management as reference information on the growth and productivity of Russia's forests.

Data Availability. Leading agencies for agricultural and forestry statistics are the Ministry of Agriculture, Federal Forestry Statistics and the National Statistics Institute. Crop production, 
acreages, and yield are provided annually at an economy-wide level; and forestry statistics are available by region and province.

\section{References}

1. Ablaev, A., Russian Biofuels Association, Russia and CIS: Biofuel Resources, presentation at the $5^{\text {th }}$ APEC Biofuels Task Force in Golden Colorado, USA, October 2008, http://www.biofuels.apec.org/task force meeting 2008-10.html

2. Checkbiotech.org, Putin encourages farmers to produce biofuels: Russia as a green energy giant, October 2007, http://www.checkbiotech.org/

3. FAO Committee on Forestry, Russian Remote Sensing Technologies for Forest Monitoring, March 2007.

4. Federal Forestry Statistics, Accessed May 2008, http://www.rosleshoz.gov.ru/english/regions/woods

5. Fischer, G., S. Prieler, et al. (2005). "Biomass potentials of miscanthus, willow and poplar: results and policy implications for Eastern Europe, Northern and Central Asia." Biomass and Bioenergy 28(2): 119-132.

6. International Energy Agency (IEA), Country energy statistics, Oil in Russia, 2005, http://www.iea.org/Textbase/country/index.asp

7. Ministry of Agriculture, Accessed April 2008, http://www.mcx.ru/

8. National Statistics Institute, Accessed April 2008, http://www.gks.ru

9. Shvidenko, A., et al. (2007), "Semi-empirical models for assessing biological productivity of Northern Eurasian forests", Ecological Modeling (204): 163-179.

10. Space Research Institute, Accessed May 2008, http://www.iki.rssi.ru/eng/index.htm

11. U.S. Department of Agriculture (USDA), Data Provided by Index Mundi, Accessed March 2008, http://indexmundi.com/

12. U.S. Department of Agriculture (USDA), Foreign Agricultural Service, Biofuels in Russia, GAIN Report, June 2007, http://www.fas.usda.gov/gainfiles/200706/146291296.pdf 


\section{Singapore}

Singapore is a highly urbanized and industrialized economy with a land area of $697 \mathrm{sq} \mathrm{km}$ and a population of 4.2 million. The biomass resources available in Singapore are municipal wastes, including wood waste, horticultural waste, food waste, and waste paper. These wastes are used to generate power in waste-to-energy or cogeneration plants. Singapore generated about 5.6 Mt of waste in 2007 (its composition is illustrated in Table 27).

Biodiesel feedstock available domestically is waste oil, including recycled and grease trap oils from restaurants and food-processing industries. However, no estimates of their quantity were available at the time this survey took place.

Singapore is trying to position itself as a major biofuels processing and trading hub in Asia, rather than a feedstock producer. The economy has a well-established trading market and infrastructure already in place, and its shipping terminals would allow transportation of biofuels to many places throughout the world. It also has proximity to feedstock suppliers (such as Malaysia and Indonesia for palm oil) and emerging high-demand centers (India and China for example).

Table 27. Municipal Waste Generation in Singapore, 2007

\begin{tabular}{|l|c|c|c|}
\hline Waste Stream & $\begin{array}{c}\text { Amt of Waste } \\
\text { Generated } \\
\text { (mil tons/yr) }\end{array}$ & $\begin{array}{c}\text { Amt of Waste } \\
\text { Recycled } \\
\text { (mil tons/yr) }\end{array}$ & $\begin{array}{c}\text { Recycling } \\
\text { Rate } \\
(\%)\end{array}$ \\
\hline Used Slag & 0.53 & 0.52 & 99 \\
\hline $\begin{array}{l}\text { Construction } \\
\text { Debris }\end{array}$ & 0.78 & 0.76 & 98 \\
\hline Ferrous Metal & 0.74 & 0.67 & 91 \\
\hline Scrap Tyres & 0.03 & 0.02 & 96 \\
\hline Non-ferrous Metal & 0.09 & 0.08 & 82 \\
\hline Wood & 0.25 & 0.13 & 52 \\
\hline Paper/Cardboard & 1.20 & 0.62 & 51 \\
\hline Horticultural & 0.22 & 0.09 & 41 \\
\hline Waste & 0.66 & 0.08 & 11 \\
\hline Plastics & 0.07 & 0.01 & 9 \\
\hline Glass & 0.56 & 0.05 & 9 \\
\hline Food & 0.11 & 0.01 & 7 \\
\hline Textiles & 0.25 & 0.01 & 6 \\
\hline Others & 0.12 & 0.00 & 0 \\
\hline Sludge & 5.60 & 3.03 & 54 \\
\hline Total & & & \\
\hline Source: & & & 9 \\
\hline
\end{tabular}

Source: MEWR, 2008 


\section{References}

1. Ministry of the Environment and Water Resources (MEWR), Solid waste management, accessed February 2008, http://app.mewr.gov.sg/web/Contents/Contents.aspx?Contld=680

2. National Climate Change Committee, accessed February 2008, http://www.nccc.gov.sg/renewables/biomass.shtm

3. National Environmental Agency (NEA), accessed February 2008, http://app.nea.gov.sg/ 


\section{Chinese Taipei}

\section{Economy-Wide Biofuels Resource Assessments}

\section{First-Generation Biofuels Potential}

Ethanol: Crops in Chinese Taipei have the largest share of total agricultural production, about $45.81 \%$, followed by livestock $(31.33 \%)$, fishery $(22.72 \%)$, and forestry $(0.14 \%)$. Rice is the most valuable crop in the economy, with more than 1.56 Mt produced in 2006 from 263,000 ha of land. Sweet potato is next on the list with about 235,000 tonnes. The production of corn $(83,000$ tonnes), grain sorghum (5,000 tonnes), wheat, and cassava is relatively small. Chinese Taipei imports large quantities of wheat, corn, and cassava for domestic food consumption and it exports very small amount of the crops it produces.

Chinese Taipei was formerly one of the world's leading sugar exporters. In the 1950s and 1960s, more than 100,000 hectares of land were dedicated to sugar cane production, with more than $1 \mathrm{Mt}$ of sugar produced annually. However, increasing labor costs and steadily declining prices during the following decades dealt a heavy blow to the industry. By 2006, only 10,390 hectares were under cultivation (GIO 2008).

If the equivalent of $20 \%$ of Chinese Taipei's current starch crops production were devoted to biofuels owing to increased yields over time, about $0.08 \mathrm{hm}^{3}$ of ethanol $(39,000$ tonnes gasoline equivalent). This volume would only be enough to replace $0.5 \%$ of Chinese Taipei's current gasoline consumption and $0.1 \%$ of its crude oil imports.

Biodiesel: Chinese Taipei produces small amount of vegetable oils (soybeans, peanuts, and sesame, in particular), thus it relies on imports to satisfy domestic consumption. A study on biodiesel potential in Chinese Taipei (Tsai 2007) estimated the amount of vegetable oil, used cooking oil, and animal fat available in 2000 at about 608,000 tonnes: vegetable oil (mostly soybean) - 419,000 tonnes, used cooking oil - 140,000 tonnes, and animal fat (lard) - 49,200 tonnes. Used cooking oil will be the main feedstock for the planned biodiesel production facilities in Chinese Taipei. 
If $20 \%$ of Chinese Taipei's current soybean oil production, as well as all waste oils and fats, were refined into biofuels, it would yield about $0.27 \mathrm{Mt}$ of biodiesel per annum. This amount would replace $7.3 \%$ of the economy's current diesel consumption and $0.5 \%$ of its crude oil imports.

\section{Second-Generation Biofuels Potential}

Lignocellulosic biomass available in Chinese Taipei includes crop, forest, and wood-processing residues. A study by Tsai et al. in 2004 assessed the crop residues (rice straw, rice husk, corn con, corn stover, and groundnut shells) available during 1990-2000. The study estimated that there were about $1.9 \mathrm{Mt}$ of crop residues available in 2000 (mostly rice straw). This amount would yield about $0.57 \mathrm{hm}^{3}$ of ethanol or $0.28 \mathrm{Mt}$ gasoline equivalent - enough to displace just $3.5 \%$ of the economy's current gasoline consumption and $0.5 \%$ of its crude oil imports.

No estimates on logging or wood-processing residues were identified during this survey. According to the Forestry Bureau, forestland occupied about 2 million ha, about $59 \%$ of the total island area (3.6 million ha). The total forest volume of the island is 359 million $\mathrm{m}^{3}$. The average forest volume per hectare is $287 \mathrm{~m}^{3}$ for conifers, $119 \mathrm{~m}^{3}$ for hardwoods, and $254 \mathrm{~m}^{3}$ for mixed forests.

\section{Biomass Resource Assessment Capabilities}

Although no detailed biomass resource assessment was found for Chinese Taipei, the economy appears to have good capabilities to conduct this type of analyses.

Leading agencies providing expertise in agriculture and forestry are the Agricultural Research Institute and Forest Research Institute. Several universities also have been involved in analyzing biomass resources. They include:

- Department of Forestry, National Chung-Hsing University, Taichung

- School of Forestry and Resource Conservation, National Taiwan University, Taipei

- Department of Environmental Engineering and Science, Chia Nan University of Pharmacy and Science, Tainan 
Geospatial Techniques. The Center for Space and Remote Sensing Research at the National Central University provides expertise in geospatial technologies. Researchers at the Department of Resource and Environment Studies-Leader University have used GIS to estimate and map areas suitable for growing sugar cane. GIS is also used by the Forestry Bureau to map forest resources, soils, land use, and other parameters for their analysis, as illustrated in Figure 29.

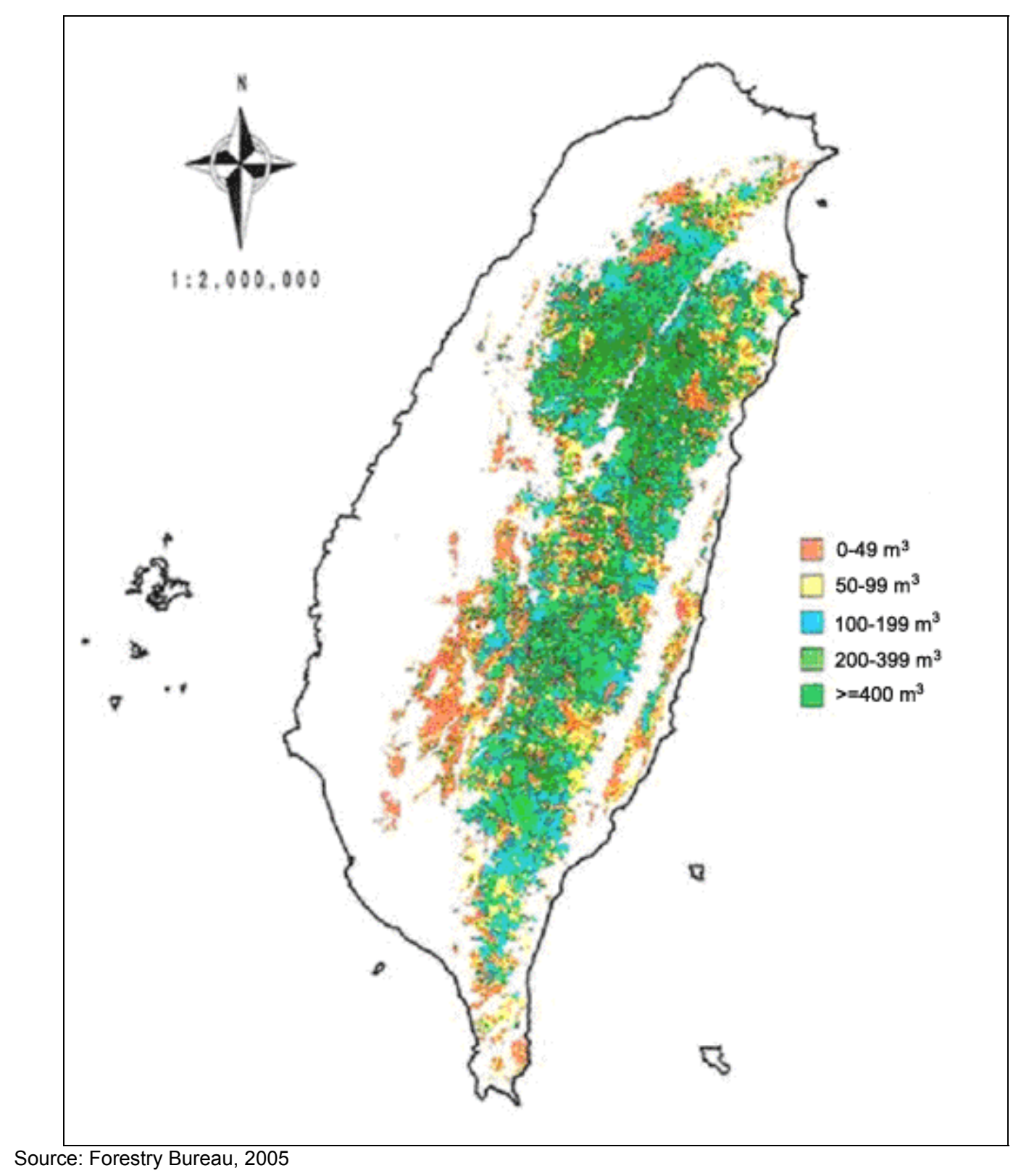

Figure 29. Map of Timber Volume of National Forest in Chinese Taipei 
Data Availability. Chinese Taipei collects agricultural and forestry statistics on a regular basis. The Council of Agriculture, Executive Yuan-Agriculture and Food Agency (AFA) provides annual and monthly statistics on area planted, area harvested, production, and yield per hectare for all crops grown in Chinese Taipei since 1946, at an economy-wide and county level. Another Council of Agriculture, Executive Yuan-the Forestry Bureau provides statistics on forest area and type by county, as well as natural and plantation forest acres and volumes by Forest District Office. Both agencies collect data via sample paper and field surveys.

\section{References}

1. Agriculture and Food Agency (AFA), Accessed May 2008, http://www.afa.gov.tw

2. Agricultural Research Institute, Accessed April 2008, http://www.tari.gov.tw/tarie/

3. Center for Space and Remote Sensing Research, National Central University, Accessed may 2008, http://www.csrsr.ncu.edu.tw/english.ver/1aboutus/csrsr intro.php

4. Forestry Bureau, Accessed April 2008, http://www.forest.gov.tw/mp.asp?mp $=3$

5. Forest Research Institute, Accessed April 2008, http://www.tfri.gov.tw/enu/index.aspx

6. Government Information Office (GIO), Accessed May 2008, http://www.gio.gov.tw/ct.asp?xltem=35667\&ctNode=2592

7. International Energy Agency (IEA), Country energy statistics, Oil in Russia, 2005, http://www.iea.org/Textbase/country/index.asp

8. Tsai, Wen-Tien, et al., (2007), "An analysis of biodiesel fuel from waste edible oil in Taiwan", Renewable and Sustainable Energy Reviews (11): 838-857

9. Tsai, Wen-Tien, et al., (2004), "Progress in energy utilization from agrowastes in Taiwan", Renewable and Sustainable Energy Reviews (8) 461-481

10. Yue, Cheng-Dar, et al. (2006), "GIS-based evaluation of multifarious local renewable energy sources: a case study of the Chigu area of southwestern Taiwan', Energy Policy (34): 730-742 


\section{Thailand}

\section{Economy-Wide Biofuels Resource Assessments}

\section{First-Generation Biofuels Potential}

Ethanol: Almost $90 \%$ of ethanol currently produced in Thailand is from sugar cane molasses, with the remaining $10 \%$ from cassava; however, the proportion is expected to shift over time in favor of cassava. Other crops suitable for ethanol production in Thailand include rice and corn. A study by the Metal and Materials Technology Center (MTEC) estimated that, in 2002, there were about $3 \mathrm{Mt}$ of molasses and $9 \mathrm{Mt}$ of cassava remaining after domestic consumption and export. The study estimates that this amount can produce about 2 million liters of ethanol, enough to supply the current production of gasohol (blend of $10 \%$ ethanol with gasoline). Thailand produces about 20 Mt of cassava per year, which translates into roughly 3 million liters of ethanol. If $20 \%$ of Thailand's current starch and sugar crops production could be used to produce ethanol, it would yield $2.7 \mathrm{hm}^{3}$ or $1.3 \mathrm{Mt}$ gasoline equivalent per annum - enough to replace $25 \%$ of the economy's current gasoline consumption and $3 \%$ of its crude oil imports.

Biodiesel: In Thailand, palm oil is the main raw material used for biodiesel. The economy ranks third in the world after Indonesia and Malaysia for total crude palm oil output with about $1 \mathrm{Mt}$ a year (about 800,000 tonnes goes to the food sector). About 420,000 tonnes are needed to make $B 2$, and at least 600,000 tonnes are required to make B5. The government plans to expand the palm oil cultivation area by 2.5 million Rai ( 1 hectare $=6.25$ Rai) during the next five years. Thailand also grows coconut, soybeans, and a small amount of sunflower. If $20 \%$ of Thailand's current vegetable oil production could be spared for biodiesel production, it would yield about $0.22 \mathrm{Mt}$ per annum, replacing $1.7 \%$ of current diesel consumption and $0.5 \%$ of crude oil imports.

\section{Second-Generation Biofuels Potential}

Ethanol: A study by the Department of Alternative Energy Development and Efficiency (DEDE) estimated the amount of agricultural residues and their energy potential in crop year 2002-2003. This is a nationwide study with no finer geography, and it uses crop-to-residue factors to assess the available crop residues. Table 28 illustrates the results of this analysis. About $46 \mathrm{Mt}$ of crop residues, sugar cane bagasse, oil-palm and coconut residues were available in Thailand during 
the year studied. Another study, conducted by the Energy Policy and Planning Office of the Ministry of Energy and Black \& Veatch Corporation (Pletka 2001), estimated the amount of available unused wood residues at $1.8 \mathrm{Mt}$ per year. The study considered sawdust and other residues from the wood-processing industry. The total amount of crop and wood residues in Thailand comes to about $47.8 \mathrm{Mt}$, which would yield about $14 \mathrm{hm}^{3}$ of ethanol or $6.9 \mathrm{Mt}$ gasoline equivalent - enough to replace $130 \%$ of current gasoline consumption and $17 \%$ of crude oil imports.

Table 28. Agricultural Residues in Thailand, 2002-2003

\begin{tabular}{|c|c|c|c|c|c|c|c|c|}
\hline \multirow{2}{*}{$\begin{array}{l}\text { Major } \\
\text { Crop: }\end{array}$} & \multirow{2}{*}{$\begin{array}{l}\text { Crop }{ }^{10} \\
\text { Output } \\
\text { (ktons) }\end{array}$} & \multirow{2}{*}{$\begin{array}{l}\text { Types of } \\
\text { Residue }\end{array}$} & \multicolumn{3}{|c|}{ Conversion factor" } & \multirow{2}{*}{$\begin{array}{l}\text { Residue } \\
\text { Amount } \\
\left(10^{6} \text { tons) }\right.\end{array}$} & \multirow{2}{*}{$\begin{array}{l}\text { Total } \\
\text { Energy } \\
\left(10^{6} \mathrm{GJ}\right)\end{array}$} & \multirow{2}{*}{$\begin{array}{l}\text { Crude Oil } \\
\text { Equivalent } \\
\left(10^{5} \text { toe }\right)\end{array}$} \\
\hline & & & $\begin{array}{l}\text { Residue } \\
\text { Ratio }\end{array}$ & $\begin{array}{l}\text { Surplua } \\
\text { Available } \\
\text { Factor }\end{array}$ & $\begin{array}{l}\text { Heat } \\
\text { Content } \\
(\mathrm{M} . \mathrm{J} / \mathrm{kg})\end{array}$ & & & \\
\hline $\begin{array}{l}\text { Sugar } \\
\text { Cane }\end{array}$ & 74,258 & $\begin{array}{l}\text {-Bagasse } \\
\text {-Top \& Trashes }\end{array}$ & $\begin{array}{l}0.29^{(2)} \\
0.30^{(2)}\end{array}$ & $\begin{array}{l}0.01^{(2)} \\
0.98^{(8)}\end{array}$ & $\begin{array}{r}8.31 \\
16.42\end{array}$ & $\begin{array}{l}0.215 \\
21.83\end{array}$ & $\begin{array}{r}1.79 \\
358.45\end{array}$ & $\begin{array}{l}0.04 \\
8.48\end{array}$ \\
\hline Paddy & 26,057 & $\begin{array}{l}\text {-Husk } \\
\text {-Stalk }\end{array}$ & $\begin{array}{l}0.23^{(7)} \\
0.45^{(2)}\end{array}$ & $\begin{array}{l}0.45^{(2)} \\
0.78^{(8)}\end{array}$ & $\begin{array}{l}15.56 \\
15.51\end{array}$ & $\begin{array}{l}2.70 \\
9.15\end{array}$ & $\begin{array}{r}42.01 \\
141.92\end{array}$ & $\begin{array}{l}0.99 \\
3.36\end{array}$ \\
\hline Maize & 4,230 & -Corn Cob & $0.27^{(27)}$ & $0.58^{(2)}$ & 16.63 & 0.66 & 10.98 & 0.26 \\
\hline Cascava & 16,868 & $\begin{array}{l}\text {-Stalk } \\
\text {-Rhizome }\end{array}$ & $\begin{array}{l}0.09^{(x)} \\
0.49^{(x)}\end{array}$ & $\begin{array}{l}0.70^{\infty 0} \\
0.98^{\infty 60}\end{array}$ & $\begin{array}{r}13.38 \\
10.61 \\
\end{array}$ & $\begin{array}{l}1.06 \\
8.10 \\
\end{array}$ & $\begin{array}{l}14.18 \\
85.94 \\
\end{array}$ & $\begin{array}{l}0.34 \\
2.03 \\
\end{array}$ \\
\hline Palm Oil & 4,001 & $\begin{array}{l}\text {-Bunches } \\
\text {-Fiber } \\
\text {-Kernel Shell }\end{array}$ & $\begin{array}{l}0.43^{16} \\
0.15^{16} \\
0.05^{16}\end{array}$ & $\begin{array}{l}0.58^{(4)} \\
0.13^{(4)} \\
0.04^{(4)}\end{array}$ & $\begin{array}{l}19.41 \\
19.94 \\
21.13\end{array}$ & $\begin{array}{l}1.00 \\
0.078 \\
0.008\end{array}$ & $\begin{array}{l}19.41 \\
1.56 \\
0.17\end{array}$ & $\begin{array}{l}0.46 \\
0.04 \\
0.004\end{array}$ \\
\hline Coconut & 1,418 & $\begin{array}{l}\text {-Husk } \\
\text {-Shell } \\
\text {-Bunches }\end{array}$ & $\begin{array}{l}0.362^{89} \\
0.160^{19} \\
0.049^{81}\end{array}$ & $\begin{array}{l}0.59^{50} \\
0.38^{5} \\
0.84^{5}\end{array}$ & $\begin{array}{l}16.23 \\
17.93 \\
15.40 \\
\end{array}$ & $\begin{array}{l}0.303 \\
0.086 \\
0.058 \\
\end{array}$ & $\begin{array}{l}4.92 \\
1.55 \\
0.90 \\
\end{array}$ & $\begin{array}{l}0.116 \\
0.037 \\
0.021 \\
\end{array}$ \\
\hline Soybean & 260 & $\begin{array}{l}\text {-Stalk, } \\
\text { leave, shell }\end{array}$ & $2.663^{19}$ & $0.76^{\infty}$ & 19.44 & 0.526 & 10.23 & 0.24 \\
\hline \multicolumn{5}{|c|}{ Total Residues (Million tons) } & & 45.77 & & \\
\hline \multicolumn{5}{|c|}{ Total Energy (Million GJ) } & & & 694.01 & \\
\hline \multicolumn{5}{|c|}{ Total OII Equivalent (Million toe) } & & & & 16.43 \\
\hline Source:(1) & $\begin{array}{l}\text { enter for A } \\
2002 / 03 \\
\text { DEDF, Rep } \\
\text { DEDF, Rep } \\
\text { DEDF, Rep } \\
\text { DEDF, Rep } \\
\text { DEDF, The }\end{array}$ & $\begin{array}{l}\text { gricultural Informs } \\
\text { ort on Biomasa R } \\
\text { ort on Cassava R } \\
\text { ort on the Inveatig } \\
\text { Study of Behavio }\end{array}$ & $\begin{array}{l}\text { n, Agricult: } \\
\text { due Invest } \\
\text { due Investi } \\
\text { on of Resio } \\
\text { due Investio } \\
\text { ha Pattern: }\end{array}$ & $\begin{array}{l}\text { ral Statistice } \\
\text { ation from F } \\
\text { gation in Nak } \\
\text { Je from Pain } \\
\text { ation, } 1994 \\
\text { of Energy U }\end{array}$ & $\begin{array}{l}\text { of Thailand } \\
\text { orm and In } \\
\text { Oil Rateha } \\
\text { Onduat }\end{array}$ & $\begin{array}{l}\text { Crop Year, } \\
\text { uatry Sector } \\
\text { ima provine } \\
1995\end{array}$ & $\begin{array}{l}2001 \\
., 2000\end{array}$ & \\
\hline
\end{tabular}

Source: DEDE, 2004 
Biodiesel: For biodiesel production, Thailand considers jatropha as an alternative feedstock, and several trial plantations have been developed in the past few years.

\section{Regional and Local Biomass Resource Potential}

Researchers at the King Mongkut's University of Technology Thonburi have developed an Atlas of Agricultural Residues in Thailand (Chanthunyagarn et al. 2004). The atlas uses GIS to illustrate the geographic distribution of residues including rice husk, sugar cane bagasse, oilpalm residues, and forest residues. It also provides data related to land use, crop production, water resources, soils, infrastructure, and other related information. Figure 30 shows crops and crop residues in one of Thailand's provinces as an example.

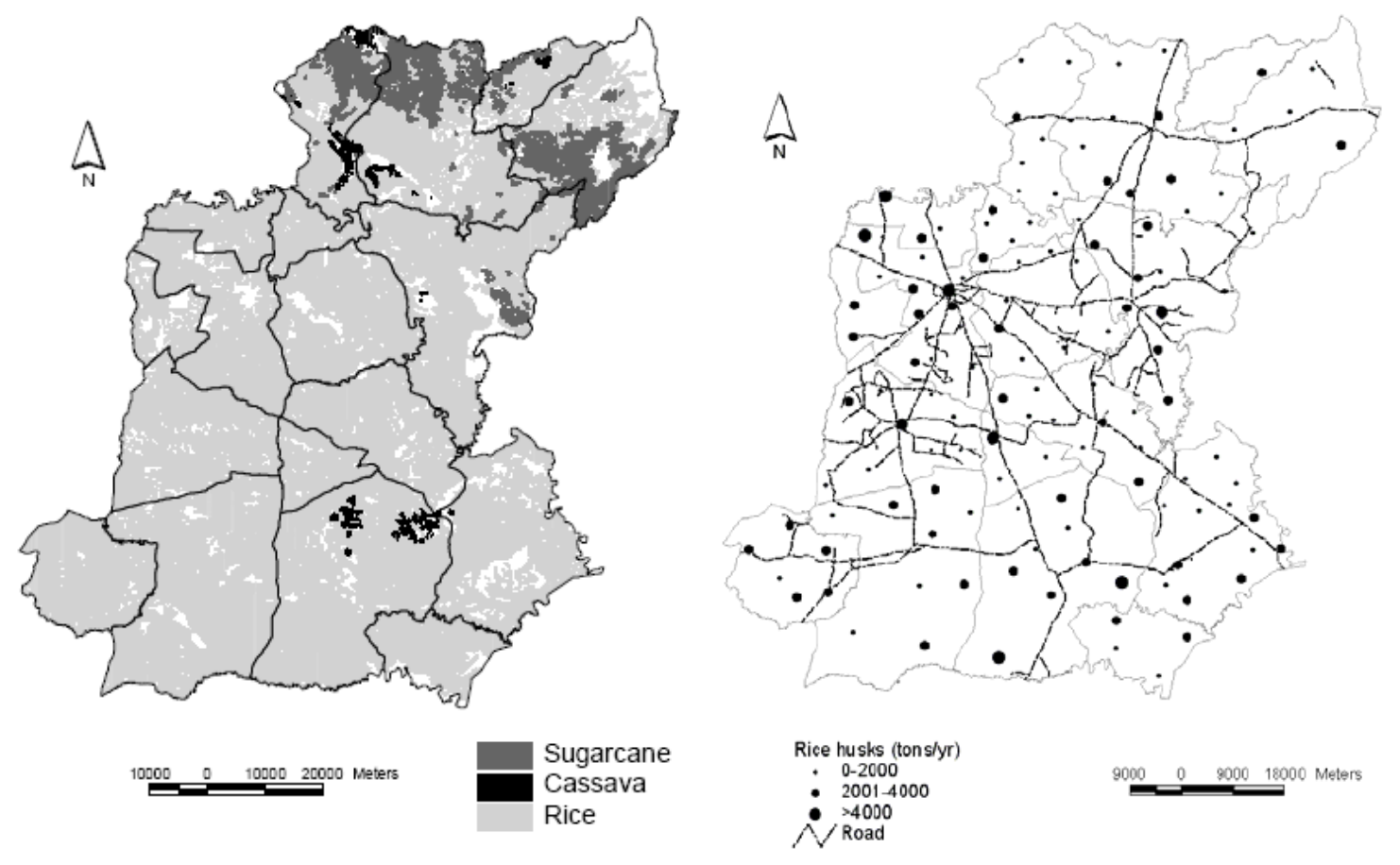

Source: Chanthunyagarn, S. et al., 2004

Figure 30. Crops and Crop Residues in Roi-Et Province, Thailand

\section{Biomass Resource Assessment Capabilities}

Thailand appears to have very good biomass resource assessment capabilities including agricultural and forestry expertise, and use of geospatial technologies, modeling, and systematically collected statistics. 
Leading agencies providing agricultural and forestry expertise include the Department of Agriculture and Royal Forestry Department. Several universities also have been involved in assessing biomass resources such as the Faculty of Forestry at the Kasetsart University, Department of Mechanical Engineering and Department of Industrial Biotechnology at the Prince of Songkla University, and Joint Graduate School of Energy and Environment at King Mongkut's University of Technology Thonburi. As with other economies, a university or college with relevant programs would offer expertise in the field.

Geospatial Capabilities. In addition to the example illustrated earlier, GIS and RS have been used by the Department of Agriculture to assist in the differentiation of major agricultural crops, estimation of crop acreage, and yield forecasting. Moreover, remotely sensed data have been effectively used in assessment of damage on crops resulting from severe weather such as drought and flood. The Royal Forest Department uses RS and GIS in combination with sample ground surveys to assess existing forest land, and identify shifting cultivation and watershed areas, as well as areas of cut forest.

Modeling. Researchers at the Department of Mechanical Engineering, Prince of Songkla University, in collaboration with Kyoto University have developed mathematical models to determine the fuel cost and optimum capacity of rubber wood-fired power plants based on fuel availability. Further, the models were integrated with GIS to locate the appropriate sites and sizes of the power plants (Krukanont and Prasertsan 2004). The Department of Agriculture and the Royal Forest Department also have been using advanced modeling techniques to assess and forecast crop and forest productivity.

Data Availability. The Office of Agricultural Economics (OAE) is the prime office responsible for collection and dissemination of agricultural statistics. It collects data on crop area planted, harvested, production, and yield annually at an economy-wide and provincial level. OAE uses several methods for data collection including sample paper and ground surveys, face-to-face interviews, statistical models, and geospatial techniques. Various methods for data collection are also used by the Royal Forest Department, which provides forestry statistics at a national, regional, and provincial level annually. 


\section{References}

1. Chanthunyagarn, S. et al., Bioenergy Atlas of Agricultural Residues in Thailand, Presented at Sustainable Energy and Environment (SEE), Hua Hin, Thailand, December 2004, http://www.energy-based.nrct.go.th/Article/Ts3\%20bioenergy\%20atlas\%20of\%20agricultural\%20residues\%20in\%20thailand.pdf

2. Krukanont, P. and Prasertsan, S., (2004), "Geographical distribution of biomass and potential sites of rubber wood !red power plants in Southern Thailand", Biomass and Bioenergy (26): 47-59

3. Metal and Materials Technology Center (MTEC), Potential Crops for Ethanol Production in Thailand, Poster presented at the Second Biomass Asia Workshop, Bangkok, Thailand, December 2005, http://www.biomass-asiaworkshop.jp/biomassws/02workshop/reports/20051213PP03-10p.jpg

4. Metal and Materials Technology Center (MTEC), Potential Crops for Biodiesel in Thailand, Poster presented at the Second Biomass Asia Workshop, Bangkok, Thailand, December 2005, http://www.biomass-asiaworkshop.jp/biomassws/02workshop/reports/20051213PP03-11p.jpg

5. Office of Agricultural Economics (OAE), Accessed May 2008, http://www.oae.go.th/statistic/yearbook/2002-03/indexe.html

6. Ongsomwang, S., Royal Forest Department, Remote Sensing and GIS Activities in Thailand, 2000, http://geoinformatics.sut.ac.th/sut/vichagan/tepin/REMOTE\%20SENSING\%20AND\%20 GIS\%20ACTIVITIES\%20IN\%20THAILAND.pdf

7. Pletka, R., Biomass-Based Power Generation and Co-generation Within Small Rural Industries of Thailand, 2001, http://www.nrbp.org/papers/037.pdf

8. Regional Data Exchange System (RDES), FAO, Metadata for National Agricultural Statistics - Thailand, 2006, http://faorap-apcas.org/rdes/PPT/thailand metadata.pdf

9. Sajjakulnukit, B., et al. (2005), "Assessment of sustainable energy potential of nonplantation biomass resources in Thailand", Biomass and Bioenergy (29): 214-224.

10. Sabhasri, S., et al., Remote Sensing Activities in Thailand, Presented at the First Asian Conference on Remote Sensing at the National Research Council of Thailand, Bangkok, November 1980, http://www.aars-acrs.org/acrs/proceeding/ACRS1980/Papers/NR801.htm

11. Suwannakhanthi, N., Department of Alternative Energy Development and Efficiency (DEDE), Overview for Thailand's Renewable Energy focusing on Biomass Energy, August 2004, http://www.dtn.moc.go.th/dtn/tradeinfo/file/files 1/Thailand Biomass.pdf

12. U.S. Department of Agriculture (USDA), Biofuels in Thailand, GAIN Report, 2007, http://www.fas.usda.gov/gainfiles/200706/146291285.pdf

13. U.S. Department of Agriculture (USDA), Data Provided by Index Mundi, Accessed March 2008, http://indexmundi.com/ 


\section{United States}

\section{Economy-Wide Biofuels Resource Assessments}

\section{First-Generation Biofuels Potential}

Ethanol: Today, nearly all ethanol in the United States is made from corn grain. Production grew $24 \%$ in just one year, from 268 Mt in 2006 to 332 Mt in 2007. About $20 \%$ of U.S. corn went into ethanol production in 2007, and the United States Department of Agriculture (USDA) has projected that in 2008, the total use of corn for ethanol will approach $30 \%$ of the U.S. crop. About 29 million ha were planted with corn in 2006, which increased in 2007 to 35 million ha. The United States is not only the world's top corn producer, but also the top exporter. On average, about $20 \%$ of U.S. corn is exported. During the government's fiscal year 2007 (October 2006 - September 2007), the United States exported about 64 Mt of corn. Ethanol also provides a rapidly growing environment for other grains, such as sorghum. Ethanol production consumed approximately $26 \%$ of the nation's sorghum crop in 2006 (10 Mt).

The USDA completed a study that investigates the economic feasibility of producing ethanol from sugar feedstocks in the United States (USDA 2006). These sugar feedstocks include sugar cane juice, sugar beet juice, cane or beet molasses, raw sugar, and refined sugar. The study concluded that it is economically feasible to make ethanol from molasses, considering the lower production cost in comparison to ethanol from corn. Producing ethanol from the remaining sugar feedstocks in the United States is not cost competitive with corn - they are more than twice the production cost of converting corn into ethanol.

If $20 \%$ of the United States' current starch and sugar crops production were used for biofuels, they would yield about $30 \mathrm{hm}^{3}$ of ethanol (14 Mt gasoline equivalent). This volume would replace about $4 \%$ of current gasoline consumption and $3 \%$ of crude oil imports. In fact, such a volume is close to actual ethanol production in 2007, which exceeded $26 \mathrm{hm}^{3}$. The Energy Independence and Security Act (EISA) of 2007 will require about a five-fold increase in biofuels production to $132 \mathrm{hm}^{3}$ by 2022 , of which it is anticipated that up to $56 \mathrm{hm}^{3}$ would come from the starch component of corn and other grains. If such an expansion of corn production from 
ethanol were achieved, it would displace $28 \mathrm{Mt}$ of gasoline equivalent, amounting to $7 \%$ of gasoline demand and 5\% of crude oil imports in the economy in the year 2005.

Biodiesel: Approximately $90 \%$ of biodiesel produced in the United States is made from soybean oil. Some experts estimate that if the biodiesel industry keeps its current momentum, more than $10 \%$ of U.S. soybean oil could be used for biodiesel production in the next few years. The United States is the world leader in soybean production with about $10 \mathrm{Mt}$ of oil produced in 2007 (USDA 2008); about $1 \mathrm{Mt}$ was exported.

A study by the National Renewable Energy Laboratory (NREL) estimated the amount of fats and waste oils available in the United States per year (Tyson et al 2004). Table 29 illustrates the results of this analysis.

Table 29. Fat and Waste Oil Supplies in the United States, 2001

\begin{tabular}{|l|r|}
\hline \multicolumn{1}{|c|}{ Fats and Oils } & \multicolumn{1}{c|}{ Tonnes/yr } \\
\hline Edible tallow & 211,000 \\
\hline Lard & 39,000 \\
\hline Inedible tallow \& greases & $1,286,000$ \\
\hline Other fats \& oils & 181,000 \\
\hline Poultry fat & 100,000 \\
\hline Fish oils & 12,700 \\
\hline Yellow grease & 184,000 \\
\hline Trap grease & $1,727,000$ \\
\hline Total & $3,740,700$ \\
\hline
\end{tabular}

If $20 \%$ of the United States' current vegetable oil production were used for biofuels, it would amount to some $1.98 \mathrm{Mt}$ per year. Adding the $3.74 \mathrm{Mt}$ of waste oils and fats that might be collected each year, a total of $5.72 \mathrm{Mt}$ of biodiesel could be produced per annum. This volume would displace $4 \%$ of 2005 U.S. diesel consumption and $1 \%$ of 2005 U.S. crude oil imports.

\section{Second-Generation Biofuels Potential}

There are many resource assessment products of lignocellulosic biomass in the United States serving different purposes (theoretical, technical and economic assessments) and at various geographic scales (nationwide, regional, state, and local). A comprehensive list of these assessments is provided in Table 30 (at the end of this section) and the most recent nationwide efforts are outlined below. 
Theoretical Assessment. An economy-wide biomass assessment completed by the Oak Ridge National Laboratory (ORNL) and the United States Department of Agriculture (USDA) is referred to as the "Billion Ton Study" (Perlack et al. 2005). This report examined whether the land resources of the United States are capable of producing a sustainable supply of biomass sufficient to displace $30 \%$ or more of the economy's petroleum consumption - the goal set by the Biomass R\&D Technical Advisory Committee (a panel established by Congress) in its vision for biomass technologies. Accomplishing this goal would require approximately 1,000 million dry tons of biomass feedstock a year. The study found that this goal could be met with resources from forest and agricultural lands (Figure 31). Forest resources - fuel wood harvested from forests, residues from wood- processing mills and pulp and paper mills, urban wood residues including construction and demolition debris, logging residues, and forest fuel treatment materials - could provide $367 \mathrm{Mt}$ of biomass. Agricultural resources - residues from major crops, perennial crops, grains, and processing residues - could provide 997 Mt. Excluding grains, the second-generation cellulosic potential from perennial crops, farm and forest residues would amount to some 1,277 Mt. With a process yielding 300 liters per tonne, this would convert to $383 \mathrm{hm}^{3}$ of ethanol or $185 \mathrm{Mt}$ of gasoline equivalent, an amount sufficient to displace $49 \%$ of 2005 U.S. gasoline consumption or $34 \%$ of 2005 U.S. crude oil imports.

These estimates of future biomass potential are based on assumptions of high crop yield increase with changes in land use, as well as agricultural and forestry practices that could significantly increase the biomass resources available for energy conversion. The study is based on regional USDA data and contains tabular summaries of the potential future sustainable biomass resources that could be supplied from agricultural and forest lands. In 2008, ORNL is pursuing the second phase of this study, updating assumptions and data where needed, as well as looking at finer regional breakouts. 


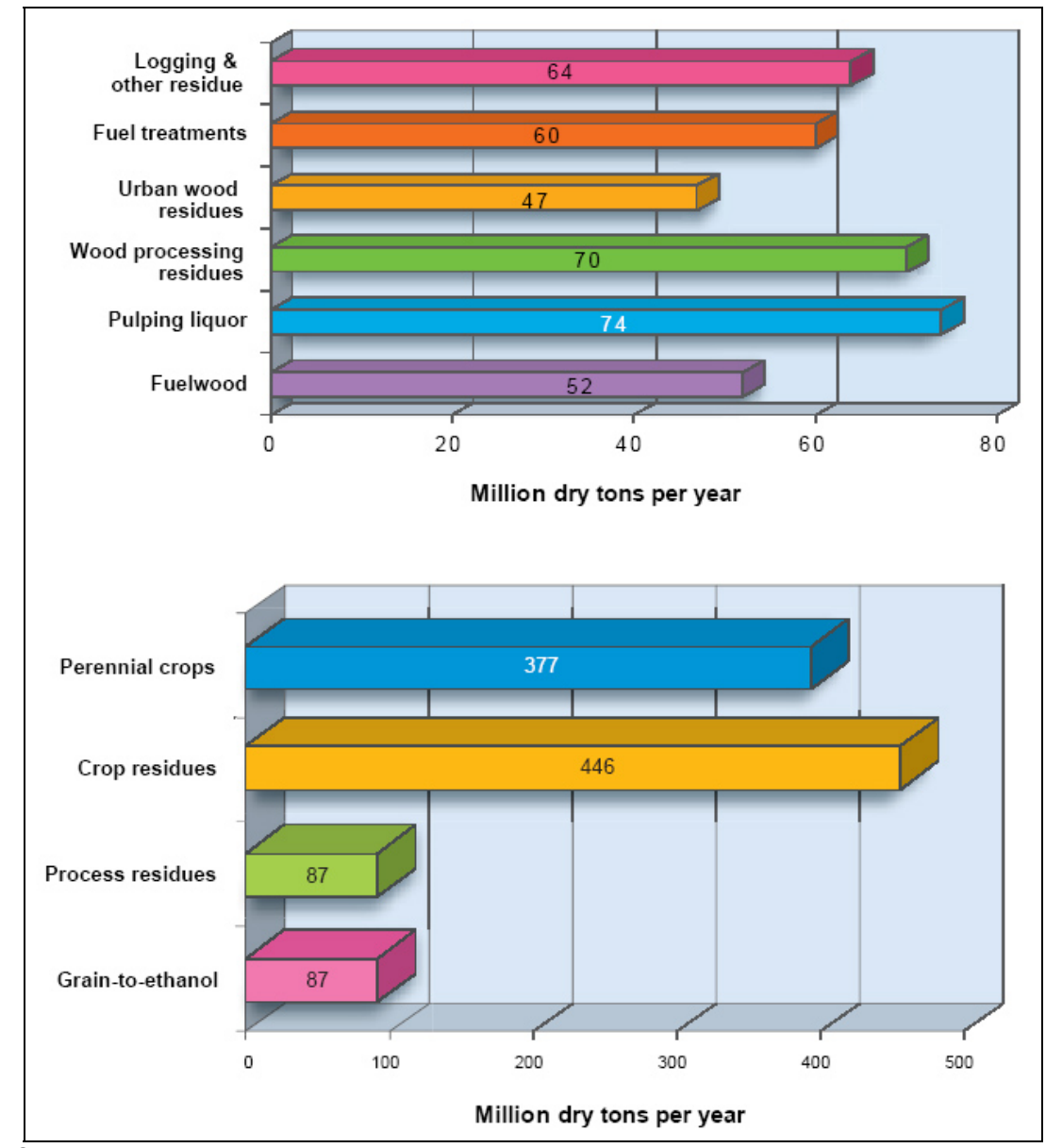

Source: Perlack et al., 2005

Figure 31. Potential Forest and Agricultural Resources in the United States

Technical Assessment. While the "high crop yield increase with land use change" scenario of the "Billion Ton Study" illustrates future potential biomass resources, a baseline summary of the same study illustrates current feedstock availability. Resources catalogued in the baseline include $113 \mathrm{Mt}$ of agricultural residues, $136 \mathrm{Mt}$ of forest residues, and $60 \mathrm{Mt}$ of waste products. The baseline second-generation biofuel potential is thus estimated to total some $309 \mathrm{Mt}$, which converts to $93 \mathrm{hm}^{3}$ of ethanol or $45 \mathrm{Mt}$ of gasoline equivalent. This would be sufficient to displace about $12 \%$ of 2005 gasoline consumption or $8 \%$ of net 2005 crude oil imports in the United States.

A study developed by the National Renewable Energy Laboratory (NREL) also focuses on currently available biomass (Milbrandt 2005). The study estimates resources at a county level and it illustrates their geographic distribution in a series of maps for each resource type. 
Analyzed feedstocks include crop residues (from 18 crops), forest residues, primary mill residues, secondary mill residues (wood scraps and sawdust from woodworking shops), urban wood (MSW wood, utility tree trimming, and construction/demolition wood), and methane emissions from manure management, landfills, and domestic wastewater treatment. It also estimates dedicated energy crops (switchgrass) that could be grown on Conservation Reserve Program (CRP) lands. The study uses GIS to collect, manipulate, analyze, and visualize the resource information, which is based on county-level statistics reported by the USDA, EPA, and the Census Bureau in 2002. The results of this analysis show that an estimated $324 \mathrm{Mt}$ of lignocellulosic biomass (crop and wood residues) could be collected in the United States annually, similarly to the results of the baseline scenario of the "Billion Ton Study". Assuming a conversion factor of 300 liters per tonne, this could provide $97 \mathrm{hm}^{3}$ of ethanol or $47 \mathrm{Mt}$ gasoline equivalent, enough to displace $12.5 \%$ of gasoline use or $8.7 \%$ of crude oil imports in 2005 . Figure 32 shows the amounts of these resources by type, while Figure 33 illustrates their distribution by county. NREL is in the process of updating this analysis with more recent data (2006-2007 statistics) and presenting it at a finer geographic resolution (1km or $250 \mathrm{~m})$.

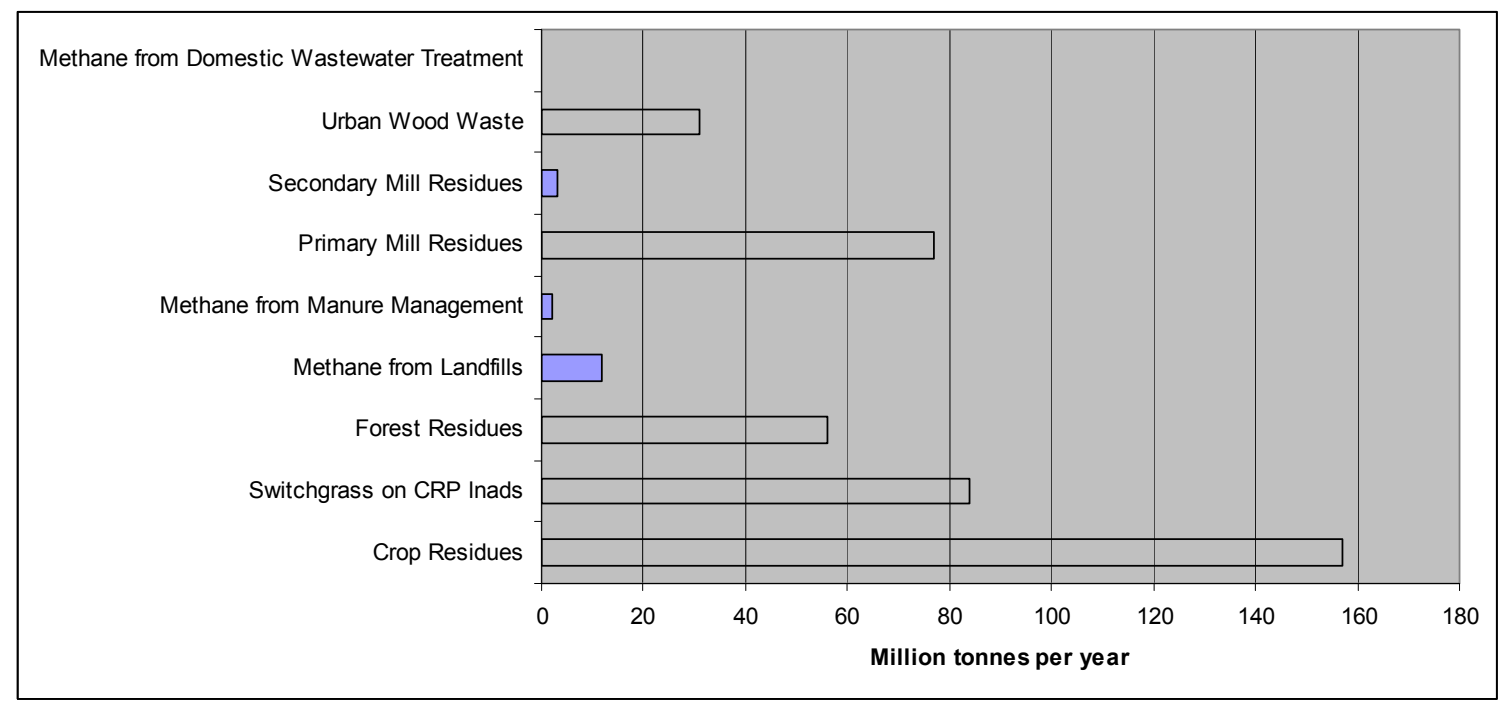

Source: Milbrandt, 2005; Methane emissions are shown in tonnes per year. Crop, forest and other solid residues are shown in dry tonnes per year.

Figure 32. Technically Available Biomass Resources in the United States 


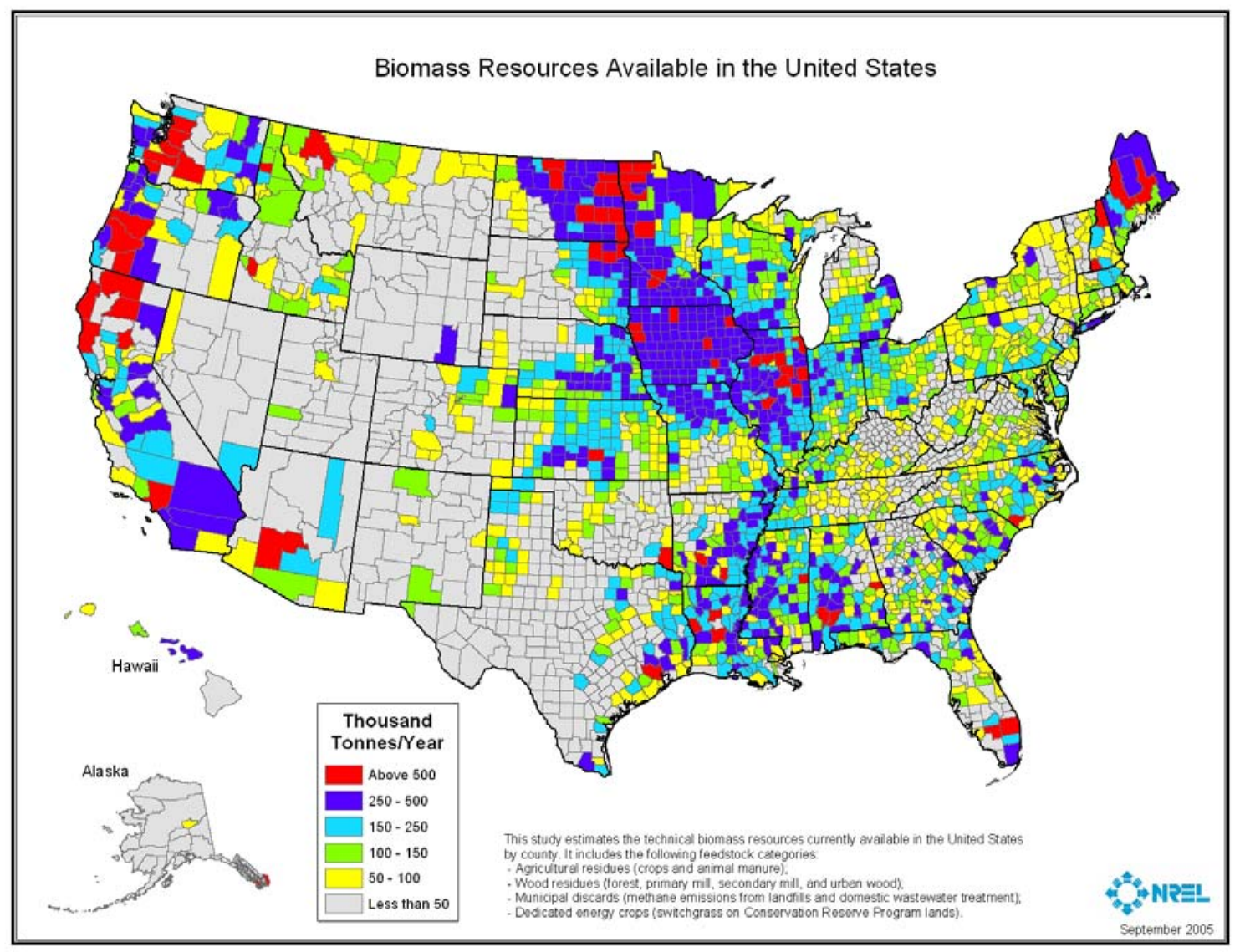

Figure 33. Biomass Resources Available in the United States by County

Economic Assessment. An economic biomass resource assessment was completed by ORNL in 1999 and updated in 2000 (Walsh et al. 2000). The assessment contains economy-wide and state-level quantities for agricultural residues (corn and wheat only), forestry residues, primary mill wastes, and urban residues that are available at specific delivered price. These supply curves are in units of US\$/dry ton ${ }^{6}$ at farm-gate or mill-gate. The estimates are derived from simulation models and analysis of various published data sources. The study found that 322 million dry tons of biomass is available annually at prices below US\$50/dry ton, and about 105 million dry tons are available at prices below US\$30/dry ton. More resources are available at a higher price due to larger collection radius leading to higher transportation costs.

Dedicated Energy Crops. ORNL has done extensive research on dedicated energy crops, including short-rotation woody crops (SRWC) such as hybrid poplars and hybrid willows, and

\footnotetext{
${ }^{6}$ Short ton, equal to $907.18 \mathrm{~kg}$
} 
herbaceous crops (switchgrass). It developed a County-Level Energy Crop (ORECCL) database in 1996, which is in Excel spreadsheet format. However, it is no longer available from the ORNL's Web site, but is being updated (there is no defined date for the new release). The database presents a median, optimistic and pessimistic yield value for each switchgrass or SRWC production region. This yield value represents the average annual yield over the lifetime of the energy crop. Lifetime is the number of years between original planting and final harvest. For hybrid poplar, the lifetime is the same as the rotation length for the stand that will be replanted after each harvest. For willow, the lifetime is presumed to be 22 years, with the first harvest occurring at the end of the fourth growing season and a harvest occurring every three years thereafter. For switchgrass, the lifetime is assumed to be 10 years. Because it takes two years for a switchgrass stand to reach mature annual production and there is no harvest in the first year of the stand, the average annual yield of switchgrass is less than that of the stand at full annual production. Figure 34 shows potential switchgrass production on Conservation Reserve Program (CRP) lands (as of July 2003) using median yield value from ORNL's energy crop database.

The economic assessment mentioned earlier (Walsh et al. 2000) estimates the quantities of energy crops that could potentially be produced at various prices. About 188 and 66 million short tons could be available at prices below US $\$ 50 /$ dry ton and US $\$ 40 /$ dry ton respectively.

Due to large uncertainties associated with energy crops production potential in the United States, these estimates are not considered in this study.

\section{Regional and Local Biofuels Resource Assessments}

Many other biomass resource assessments have been completed by individual states, such as California, Colorado, Florida, Georgia, Hawaii, Ohio, South Carolina, Washington, etc. There are also regional biomass resource assessments, such as the ones completed by the Northeast Regional Biomass Program (NRBP) for several states in the Northeast region, and the Western Governors Association (WGA) studies of biomass resource potential for both power and biofuels generation in 18 member states. Most of these assessments are based on statistical analysis of reported information and many of them use GIS to illustrate the resource's geographic distribution. Additionally, there are assessments focused on a particular feedstock with varied spatial coverage (national, regional, state, county, or city). For example, an urban wood waste assessment was completed for 30 metropolitan areas using phone interviews (Appel 
Consultants Inc. 1998). A detailed inventory of the main resource assessment products in the United States is provided in Table 30. The inventory excludes numerous articles published in academic and professional journals such as Biomass \& Bioenergy, Biomass Magazine, Ethanol Producer, and Biodiesel Producer.

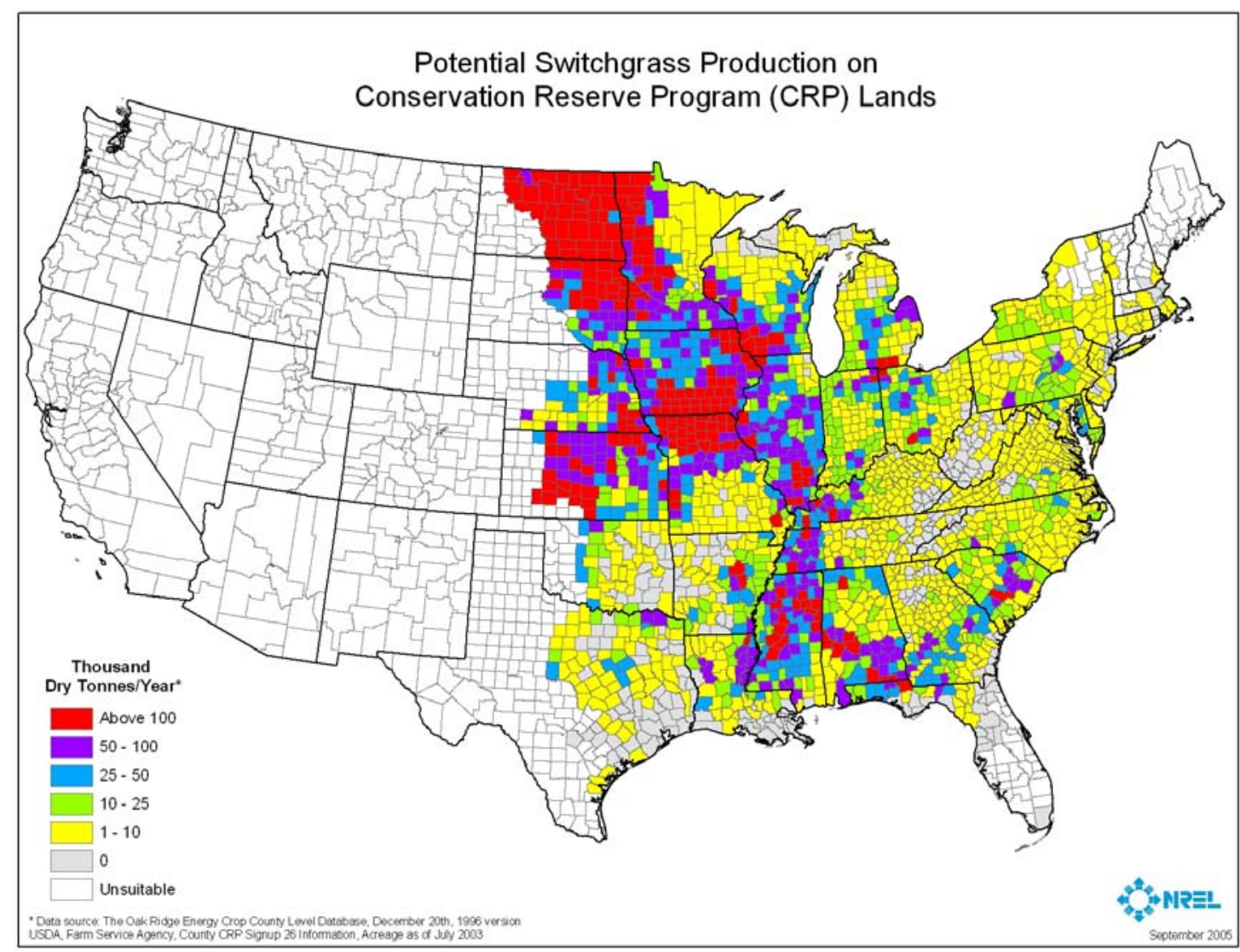

Figure 34. Potential Switchgrass Production on CRP Lands

\section{Biomass Resource Assessment Capabilities}

The United States has very strong capabilities in assessing biomass resources as illustrated above. The economy has used the full range of resource assessment methods: geospatial technologies, modeling, and survey techniques. In addition, spatial and temporal data are readily available to support future work in the area.

Leading agencies in biomass resource assessments include USDA and USDOE (ORNL and NREL, in particular). Several universities with agricultural programs are also capable of conducting resource assessments and have been involved in regional, statewide, or small-scale studies. These include University of California-Davis, Kansas State University, University of 
Minnesota, Ohio State University, Washington State, and others. In addition, a few private companies, such as Antares Group and McNeil Technologies, have been historically involved in biomass assessments.

USDA is the main source of agricultural and forestry statistics and analytical products. An abundance of information is available through several agencies, particularly the National Agricultural Statistics Service (NASS) and Forest Service (FS). NASS uses remote sensing for crop-condition monitoring, particularly in assessing the effects of severe weather on crop production. It uses a biweekly composite of the normalized difference vegetation index (NDVI) from the advanced very high resolution radiometer (AVHRR) on polar orbiting weather satellites operated by the National Oceanic and Atmospheric Administration (NOAA). The EROS Data Center of the U.S. Geological Survey archives the AVHRR data and creates a biweekly composite of the NDVI. NASS procures the biweekly composites, compares the images over time, and links them to the Weekly Crop and Weather Report issued weekly by NASS and the Joint Agricultural Weather Facility (JAWF) of USDA and NOAA. AVHRR NDVI data have one square kilometer resolution (about 250 acres). This resolution can provide substantial detail when viewing a large area such as a state, region, or country, but it can't routinely provide cropspecific information because of varying crops in the same region, field-size limitations, and alternating crop and fallow field patterns. Occasionally, remote sensing is used by NASS for estimating crop yield. However, in most cases, NASS uses two survey techniques for crop yield forecasting and estimation: the frame-based sample surveys of farm operators and field observation. Forecasts for each crop season begin with a winter wheat and rye seeding report in early January followed by a March report that gives a first look at what farmers intend to plant. This is followed in late June by a report of the acreage actually planted. Monthly yield and production forecasts begin in May for winter wheat, in July for spring wheat and other small grains, in August for other spring-planted crops, and conclude with estimates of actual production at the end of the harvesting season. NASS also conducts quarterly surveys of grain and soybeans stored on and off farms. According to NASS, AVHRR-based crop yield estimates are not nearly as precise as NASS's existing survey system for crop yield data. However, in areas with no survey or ground data systems, AVHRR-based data can provide limited year-toyear interpretations of changes in yield levels. More on the survey techniques used by NASS is available at http://www.nass.usda.gov/Data and Statistics/Foundation of Estimates/index.asp. 
The USDA Forest Service (FS) also uses remote sensing in monitoring and evaluating forest resources. It uses aerial survey, also known as aerial sketch mapping, a remote sensing technique of observing forest change events from an aircraft and documenting them manually onto a map. Aerial surveys are used as the first step of a multitiered process, together with other remote sensing and ground-sampling techniques to gather forest resource data. As with all remotely sensed data, some amount of ground-truthing is required before the data can be considered reliable. The Forest Service considers all information a draft until the ground-truthing is complete. The results of this survey are entered into GIS for further analysis.

USDA's NASS and FS agencies provide time-series statistical and spatial data at different geographic level (economy-wide, state, county, $1 \mathrm{~km}$, and $250 \mathrm{~m}$ ), as well as many analytical tools. The USDA FS developed forest inventory reporting tools, including tools for querying the National Woodland Owner Survey database and the Timber Products Output database. Another tool, the Forest Inventory Data Online (FIDO) allows users to create reports and maps using information such as tree volume, growth, and tree removals by state. More information on the tools developed by these agencies is available at http://www.fia.fs.fed.us/tools-data/default.asp

The ORNL specializes in economic analysis of biomass resources, and has developed many models to support it. The Policy Analysis System (POLYSYS) is an economy-wide simulation model of the U.S. agriculture sector, which can incorporate agricultural supply and demand and related modules to estimate agricultural production response, resource use, price, income, and environmental impacts of projected changes from an agricultural baseline. The framework recursively incorporates linear programming, econometric, and process models to estimate an impact path resulting from changes imposed on a baseline scenario and its underlying assumptions. POLYSYS estimates crop production and supply at a disaggregated regional level, whereby the 48 contiguous states are subdivided into 305 geographic regions with relatively homogeneous production characteristics. POLYSYS is capable of estimating a wide range of policy alternatives and economic and environmental conditions and simulations may be tailored to a variety of specific analytical needs.

Oak Ridge Integrated Bioenergy Analysis System (ORIBAS) is a GIS-based modeling system for predicting delivered feedstock costs across a state. It provides county-level estimates of suitable acres, yields, and farm-gate prices of energy crops (switchgrass, hybrid poplar, willow) 
for all 50 states. The latter estimates delivered feedstock prices and quantities within a state at a fine resolution (1 km2) and considers the interplay between transportation costs, farmgate prices, cropland density, and facility demand. It can be used to examine any type of feedstock given the appropriate input parameters.

Another product developed by ORNL is BIOCOST, which estimates the cost of producing hybrid poplars and switchgrass in seven regions of the United States. It is an Excel-based program with a graphical interface that lets the user select a region and then specify values for several variables including expected yields; land rents; labor costs; and prices of chemicals, fertilizers, fuel, and planting. The user can also choose among several key management options. BIOCOST generates a report that includes yearly cost estimates by cost category as well as per-acre and per-ton costs.

Although conversion technologies are the main focus of the biomass program at NREL, resource assessment work has been supported over the years. The laboratory has been involved in conducting technical resource assessments for private companies, government organizations, and nongovernment organizations within the United States and abroad.

NREL's biomass resource assessment mentioned above was used to develop an interactive Web tool, composed of geographic and analytic components, that illustrates biofuels potential and petroleum displacement by state (Figure 35). The Potential Production maps show the biomass resources within counties, as well as the existing and under-construction biodiesel and ethanol production facilities. The Potential Use maps show the Flexible Fuel Vehicle (FFV) registrations by zip code and the location of refueling stations offering ethanol and biodiesel. The analytic component has three different calculation areas: current situation, potential production, and potential use. The current situation is static for each state and shows important fuel use, infrastructure, and biomass resources data. The potential production and use calculation areas are dynamic and are used to project various production and use scenarios based on user input. The tool can be accessed at http://www.eere.energy.gov/afdc/sabre/. 

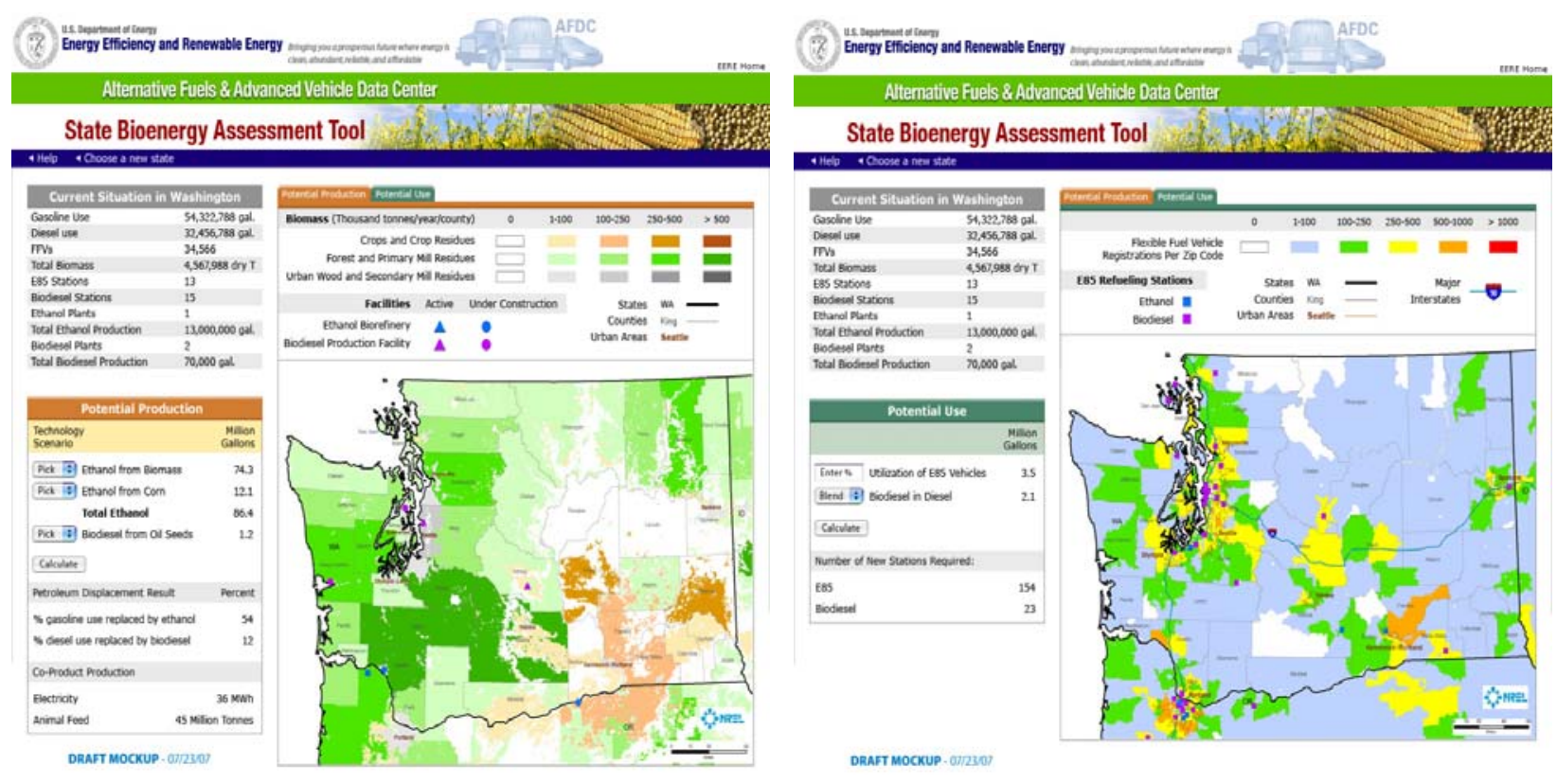

Figure 35. United States Bioenergy Assessment Tool

\section{References}

1. APEC Biofuels Task Force (BTF) Report to the Eight Energy Ministers Meeting, Darwin, Australia, May 2007, http://www.ewg.apec.org/assets/documents/apecinternet/Biofuelsreport\%5FEMM820071 $011104537 \% 2 \mathrm{Epdf}$

2. Daniel G. De La Torre Ugarte and Daryll E. Ray, Biomass and bioenergy applications of the POLYSYS modeling framework, Biomass \& Bioenergy, issue 18 (2000), page 291308

3. International Energy Agency (IEA), Country energy statistics, Oil in the United States in 2005, http://www.iea.org/Textbase/country/index.asp

4. Milbrandt, A., A Geographic Perspective on the Current Biomass Resource Availability in the United States", NREL, Golden CO, December 2005, http://www.nrel.gov/docs/fy06osti/39181.pdf

5. Tyson et al, Biomass Oil Analysis: Research Needs and Recommendations, NREL, Golden CO, June 2004, http://www1.eere.energy.gov/biomass/pdfs/34796.pdf

6. Northeast Regional Biomass Program (NRBP), Securing a Place for Biomass in the Northeast United States, Washington DC, March 2003, http://www.nrbp.org/pdfs/nrbp final report.pdf

7. Perlack et al, Biomass as Feedstock for a Bioenergy and Bioproducts Industry: The Technical Feasibility of a Billion-Ton Annual Supply, ORNL, Oak Ridge TN, April, 2005, http://feedstockreview.ornl.gov/pdf/billion ton vision.pdf

8. USDA, The Economic Feasibility of Ethanol Production from Sugar in the United States, July 2006, http://www.usda.gov/oce/reports/energy/EthanolSugarFeasibilityReport3.pdf

9. USDA, National Agricultural Statistics Service (NASS), Sample Survey and Census Programs of NASS, Accessed January 2008, http://www.nass.usda.gov/Surveys/index.asp 
10. USDA, Forest Service, Aerial Survey Viewer, Accesed January 2008, http://na.fs.fed.us/fhp/ta/av/

11. Walsh et al, Biomass Feedstock Availability in the United States, ORNL, Oak Ridge TN, January 2000, http://bioenergy.ornl.gov/resourcedata/index.html

12. Western Governors Association (WGA), Biomass Task Force Report, Denver CO, January 2006, http://www.westgov.org/wga/initiatives/cdeac/Biomass-full.pdf 
Table 30. United States Biomass Resource Assessments Inventory as of May 2008

\begin{tabular}{|c|c|c|c|c|c|c|c|c|c|}
\hline Name & Author & $\begin{array}{c}\text { Publication } \\
\text { Date }\end{array}$ & $\begin{array}{c}\text { Spatial } \\
\text { Coverage }\end{array}$ & $\begin{array}{c}\text { Spatial } \\
\text { Scale or } \\
\text { Resolution }\end{array}$ & $\begin{array}{l}\text { Temporal } \\
\text { Scale or } \\
\text { Resolution }\end{array}$ & $\begin{array}{c}\text { Methodology } \\
\text { Used }\end{array}$ & Units & Link & Abstract/Comments/Notes \\
\hline \begin{tabular}{|} 
Biomass as \\
Feedstock for a \\
Bioenergy and \\
Bioproducts \\
Industry: The \\
Technical \\
Feasibility of a \\
Billion-Ton Annual \\
Supply
\end{tabular} & ORNL & April, 2005 & National & National & $\begin{array}{l}\text { Annual } \\
\text { Potential }\end{array}$ & $\begin{array}{l}\text { Statistical } \\
\text { analysis and } \\
\text { modeling }\end{array}$ & dry ton/yr & $\begin{array}{l}\text { httho:/ffaedstockreviaw arnla a } \\
\text { ov/pdfibilition ton vision.pdf }\end{array}$ & $\begin{array}{l}\text { This report determines whether the land resources } \\
\text { are capable of producing a sustainable supply of } \\
\text { biomass sufficient to displace } 30 \% \text { or more of the } \\
\text { country's present petroleum consumption by } \\
\text { examining the potential resource availability of } \\
\text { agricultural and forest lands for biomass energy } \\
\text { production. }\end{array}$ \\
\hline $\begin{array}{l}\text { A Geographic } \\
\text { Perspective on the } \\
\text { Current Biomass } \\
\text { Resource } \\
\text { Availability in the } \\
\text { United States }\end{array}$ & NREL & $\begin{array}{c}\text { December. } \\
2005\end{array}$ & National & County & Annual & $\begin{array}{l}\text { Statistical } \\
\text { analysis and } \\
\text { GIS }\end{array}$ & $\begin{array}{l}\text { dry tonnes/year } \\
\text { for solid } \\
\text { biomass: } \\
\text { tonnes/yr for } \\
\text { gaseous }\end{array}$ & 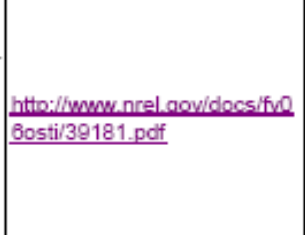 & $\begin{array}{l}\text { Resource availability based on county level } \\
\text { statistics gathered from U.S. Department of } \\
\text { Agriculture, U.S. Forest Service, and other } \\
\text { organizations. Analyzed feedstock include: crop } \\
\text { residues, forest residues, primary and secondary } \\
\text { mill residues, urban wood waste, and methane } \\
\text { emissions from manure management, landfills and } \\
\text { domestic wastewater treatment. }\end{array}$ \\
\hline $\begin{array}{l}\text { Biomass } \\
\text { Feedstock } \\
\text { Availability in the } \\
\text { United States: } \\
1999 \text { State Level } \\
\text { Analysis }\end{array}$ & ORNL & January, 2000 & National & State & Annual & $\begin{array}{l}\text { Statistical } \\
\text { analysis and } \\
\text { modeling }\end{array}$ & \$/dry ton & $\begin{array}{l}\text { http://bioenergy.oml.govires } \\
\text { ourcedata/index.html }\end{array}$ & $\begin{array}{l}\text { Estimates of biomass quantities and prices for each } \\
\text { state in the continental U.S., with links to a } \\
\text { spreadsheet containing estimates of biomass } \\
\text { quantities potentially available in five categories: } \\
\text { mill wastes, urban wastes, forest residues, } \\
\text { agricultural residues and energy crops. } \\
\text { Availabilities are sorted by anticipated delivered } \\
\text { price. }\end{array}$ \\
\hline \begin{tabular}{|c|} 
WGA CDEAC \\
Biomass Task \\
Force Report, \\
Supply Addendum
\end{tabular} & WGA & January, 2006 & \begin{tabular}{|} 
WA, OR, ID, \\
MT, WY, CO, \\
NM, AZ, UT, \\
NV, CA, TX, \\
ND, SD, NE, \\
KS, AK and HI
\end{tabular} & $\begin{array}{l}\text { State or } \\
\text { County }\end{array}$ & Annual & $\begin{array}{l}\text { Statistical } \\
\text { analysis and } \\
\text { modeling }\end{array}$ & $\begin{array}{l}\text { S/dry ton, tons, } \\
\text { gallons }\end{array}$ & 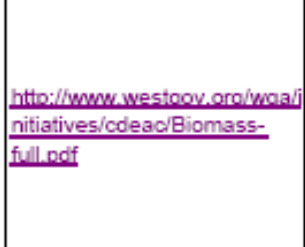 & $\begin{array}{l}\text { Estimates of quantities of various biomass } \\
\text { resources throughout the WGA region on a county } \\
\text { basis for use as feedstocks for power generation. } \\
\text { The study analyzes the following feedstock: forest } \\
\text { resources, agricultural residues } \\
\text { and products, and resources from the municipal } \\
\text { waste stream including solid wastes, } \\
\text { biosolids, sewage, and waste buried in landfills. }\end{array}$ \\
\hline
\end{tabular}




\begin{tabular}{|c|c|c|c|c|c|c|c|c|c|}
\hline Name & Author & $\begin{array}{l}\text { Publication } \\
\text { Date }\end{array}$ & $\begin{array}{c}\text { Spatial } \\
\text { Coverage }\end{array}$ & $\begin{array}{c}\text { Spatial } \\
\text { Scale or } \\
\text { Resolution }\end{array}$ & $\begin{array}{l}\text { Temporal } \\
\text { Scale or } \\
\text { Resolution }\end{array}$ & $\begin{array}{c}\text { Methodology } \\
\text { Used }\end{array}$ & Units & Link & Abstract/Comments/Notes \\
\hline $\begin{array}{l}\text { WGA CDEAC } \\
\text { Biomass } \\
\text { Resource } \\
\text { Assessment and } \\
\text { Supply Analysis }\end{array}$ & WGA & March, 2008 & $\begin{array}{l}\text { WA, OR, ID, } \\
\text { MT, WY, CO, } \\
\text { NM, AZ, UT, } \\
\text { NV, CA, TX, } \\
\text { ND, SD, NE, } \\
\text { KS, AK and HI }\end{array}$ & $\begin{array}{l}\text { State or } \\
\text { County }\end{array}$ & Annual & $\begin{array}{l}\text { Statistical } \\
\text { analysis and } \\
\text { modeling }\end{array}$ & $\begin{array}{l}\text { S/dry ton, } \\
\text { pounds, tons }\end{array}$ & N/A & $\begin{array}{l}\text { Estimates of quantities of various biomass } \\
\text { resources throughout the WGA region on a county } \\
\text { or city basis for use as feedstocks for liquid } \\
\text { biofuels. The study includes: crop residues (corn } \\
\text { stover and small-grain straws), animal fats and } \\
\text { waste greases (beef tallow, yellow grease), forest } \\
\text { biomass resources, energy crops (short-rotation } \\
\text { woody crops and herbaceous). orchard and } \\
\text { vineyard trimmings (apples, almonds, grapes, etc.). } \\
\text { biosolids, and grain and oilseeds (corn, soy, and } \\
\text { canola). }\end{array}$ \\
\hline $\begin{array}{l}\text { Assessment of } \\
\text { Biomass } \\
\text { Resources and } \\
\text { Power Generation } \\
\text { Potential in } \\
\text { California }\end{array}$ & $\begin{array}{l}\text { University of } \\
\text { California - } \\
\text { Davis }\end{array}$ & $\begin{array}{l}\text { February. } \\
2004\end{array}$ & California & $\begin{array}{l}\text { State or } \\
\text { County }\end{array}$ & Annual & $\begin{array}{c}\text { Statistical } \\
\text { analysis }\end{array}$ & dry ton/yr & $\begin{array}{l}\text { http://biomass.uodavis.edu/ } \\
\text { materials/reports\%20and\%2 } \\
\text { Opublications/2008/2006_aig } \\
\text { mass Resource Assessme } \\
\text { nt.udf }\end{array}$ & $\begin{array}{l}\text { California's gross and potential technically available } \\
\text { biomass resources were quantified and compiled } \\
\text { into statewide and county level inventories. }\end{array}$ \\
\hline $\begin{array}{c}\text { Colorado } \\
\text { Agriculture: Land, } \\
\text { Water, Energy } \\
\text { Use and } \\
\text { Bioenergy } \\
\text { Potential }\end{array}$ & $\begin{array}{c}\text { Resource } \\
\text { Analysis, Inc. for } \\
\text { Colorado Office } \\
\text { of Energy } \\
\text { Management } \\
\text { and } \\
\text { Conservation }\end{array}$ & April, 2004 & Colorado & County & Annual & $\begin{array}{c}\text { Statistical } \\
\text { analysis }\end{array}$ & $\begin{array}{c}\text { tons/yr or cubic } \\
\text { ff/day }\end{array}$ & 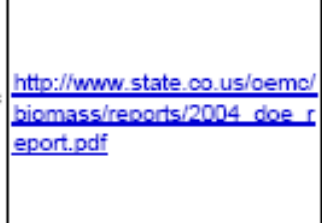 & $\begin{array}{l}\text { County-level estimates of the gross available and } \\
\text { maximum net available residue for five Colorado } \\
\text { crops and livestock manure in } 2001 \text {. }\end{array}$ \\
\hline $\begin{array}{c}\text { Biomass } \\
\text { Resource } \\
\text { Assessment and } \\
\text { Utilization } \\
\text { Options for Three } \\
\text { Counties in } \\
\text { Eastern Oregon }\end{array}$ & \begin{tabular}{|c|} 
MoNeil \\
Technologies for \\
Oregon Dept. of \\
Energy
\end{tabular} & $\begin{array}{c}\text { December. } \\
2003\end{array}$ & $\begin{array}{l}\text { Eastern } \\
\text { Oregon }\end{array}$ & $\begin{array}{l}\text { Three } \\
\text { counties in } \\
\text { Eastern } \\
\text { Oregon - } \\
\text { Baker, Union } \\
\text { and Wallowa }\end{array}$ & Annual & $\begin{array}{c}\text { Statistical } \\
\text { analysis and } \\
\text { modeling }\end{array}$ & Dry tons/yr & $\begin{array}{l}\text { hitto://wwww.oregon.gov/ENER } \\
\text { GY/RENEW/Biomass/docsLI } \\
\text { EOBRA/FullText.pdf } \\
\end{array}$ & $\begin{array}{l}\text { The assessment focused on the use of biomass for } \\
\text { electric power generation or conversion to ethanol } \\
\text { fuel in Baker, Union and Wallowa Counties. The } \\
\text { objectives were to identify how much biomass is } \\
\text { generated in the region; how much is available, } \\
\text { where it is located, its physical and chemical } \\
\text { characteristics and the cost; provide information on } \\
\text { best locations for a potential biomass site in each } \\
\text { county; evaluate the economic and environmental } \\
\text { impacts of biomass use; and provide an overview } \\
\text { of biomass energy technologies, feedstock } \\
\text { requirements, and the economic potential to } \\
\text { convert biomass to electricity or ethanol. }\end{array}$ \\
\hline
\end{tabular}




\begin{tabular}{|c|c|c|c|c|c|c|c|c|c|}
\hline Name & Author & $\begin{array}{l}\text { Publication } \\
\text { Date }\end{array}$ & $\begin{array}{c}\text { Spatial } \\
\text { Coverage }\end{array}$ & \begin{tabular}{|c|} 
Spatial \\
Scale or \\
Resolution
\end{tabular} & $\begin{array}{l}\text { Temporal } \\
\text { Scale or } \\
\text { Resolution }\end{array}$ & $\begin{array}{l}\text { Methodology } \\
\text { Used }\end{array}$ & Units & Link & Abstract/Comments/Notes \\
\hline \begin{tabular}{|c|} 
Potential for \\
Biomass Energy \\
Development in \\
South Carolina
\end{tabular} & $\begin{array}{l}\text { USDA Forest } \\
\text { Service and the } \\
\text { SC Forestry } \\
\text { Commission. }\end{array}$ & $\begin{array}{l}\text { September. } \\
2004\end{array}$ & South Carolina & $\begin{array}{l}\text { County and } \\
\text { State }\end{array}$ & Annual & $\begin{array}{c}\text { Statistical } \\
\text { analysis }\end{array}$ & $\begin{array}{c}\text { Green tons, dry } \\
\text { tons }\end{array}$ & 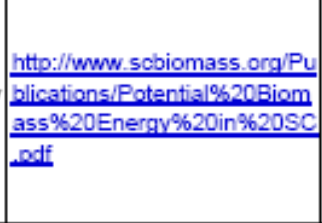 & $\begin{array}{l}\text { This report quantifies the amount of forestry and } \\
\text { agricultural biomass that is available for energy } \\
\text { production on a sustainable basis in South } \\
\text { Carolina. It also includes an analysis of the } \\
\text { economic impacts of transferring out-of-state costs } \\
\text { for coal to in-state family forest landowners and } \\
\text { biomass processors. }\end{array}$ \\
\hline $\begin{array}{l}\text { Biomass and } \\
\text { Bioenergy } \\
\text { Resource } \\
\text { Assessment for } \\
\text { the State of } \\
\text { Hawaii }\end{array}$ & $\begin{array}{l}\text { State of Hawaii } \\
\text { Department of } \\
\text { Business, } \\
\text { Economic } \\
\text { Development } \\
\text { and Tourism }\end{array}$ & $\begin{array}{c}\text { December. } \\
2002\end{array}$ & Hawaii & $\begin{array}{l}\text { County and } \\
\text { State }\end{array}$ & Annual & $\begin{array}{c}\text { Statistical } \\
\text { analysis }\end{array}$ & $\begin{array}{c}\text { Tons/yr or Dry } \\
\text { Tons/yr }\end{array}$ & $\begin{array}{l}\text { htto://fwww.hawail.gow/dbedt/i } \\
\text { nfolenerovidaublications/biom } \\
\text { ass-assessment.poff }\end{array}$ & $\begin{array}{l}\text { An assessment of current and potential biomass } \\
\text { and bioenergy resources for the State of Hawaii. It } \\
\text { includes the following feedstock: animal wastes, } \\
\text { forest products residues, agricultural residues, and } \\
\text { urban wastes }\end{array}$ \\
\hline $\begin{array}{l}\text { Biomass Wood } \\
\text { Resource } \\
\text { Assessment on a } \\
\text { County-by-County } \\
\text { Basis for the State } \\
\text { of Georgia }\end{array}$ & $\begin{array}{l}\text { State } \\
\text { Government - } \\
\text { Georgia } \\
\text { Forestry } \\
\text { Commission }\end{array}$ & $\begin{array}{l}\text { November, } \\
2005\end{array}$ & Georgia & $\begin{array}{c}\text { County and } \\
\text { State }\end{array}$ & Annual & $\begin{array}{c}\text { Statistical } \\
\text { analysis }\end{array}$ & Dry tons & 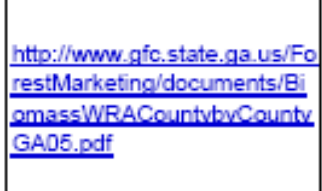 & $\begin{array}{l}\text { A biomass wood resource assessment on a county } \\
\text { level basis for the State of Georgia: forest, primary } \\
\text { mill, urban wood, pecan shells, paper mill sludge, } \\
\text { and black liquor. It also analyzes the CRP Program } \\
\text { potential. }\end{array}$ \\
\hline $\begin{array}{c}\text { Securing a Place } \\
\text { for Biomass in the } \\
\text { Northeast United } \\
\text { States: } \\
\text { A Review of } \\
\text { Renewable } \\
\text { Energy and } \\
\text { Related Policies }\end{array}$ & $\begin{array}{l}\text { Northeast } \\
\text { Regional } \\
\text { Biomass } \\
\text { Program } \\
\text { (NRBP) }\end{array}$ & Mar-03 & $\begin{array}{c}\text { CT, DE, ME, } \\
\text { MD, MA, NH, } \\
\text { NJ, NY, PA, RI, } \\
\text { VT }\end{array}$ & State & Annual & $\begin{array}{c}\text { Statistical } \\
\text { analysis }\end{array}$ & Dry tons/yr & 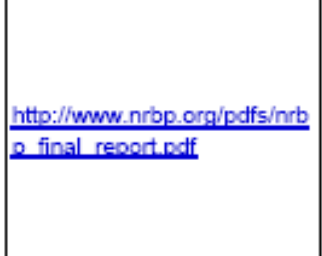 & $\begin{array}{l}\text { A survey of biomass resources, power potential, } \\
\text { and policies in the } 11 \text { states encompassing the } \\
\text { Northeast Regional Biomass Program (NRBP): CT. } \\
\text { DE, ME, MD, MA, NH, NJ, NY, PA, RI, VT. }\end{array}$ \\
\hline $\begin{array}{l}\text { Biomass from } \\
\text { Crop Residues: } \\
\text { Cost and Supply } \\
\text { Estimates. }\end{array}$ & USDA & Feb-03 & National & State, Region & Annual & $\begin{array}{c}\text { Statistical } \\
\text { analysis }\end{array}$ & $\begin{array}{c}\text { lbs/acre, lbs, } \\
\text { \$/ton }\end{array}$ & $\begin{array}{l}\text { http://www.usda.gov/oce/reo } \\
\text { orts/energy/AER819.pdf } \\
\end{array}$ & $\begin{array}{l}\text { The analysis estimated the supply of harvested } \\
\text { crop residues as a feed stock for energy products. } \\
\text { The estimates account for economic and } \\
\text { environmental factors governing residue supply. } \\
\text { The supply results span major agricultural crops in } \\
\text { four distinct cropping regions of the United States, } \\
\text { taking into account local variation in cost- } \\
\text { determining factors such as residue yield. } \\
\text { geographic density of } \\
\text { residues, and competion for livestock feed use. }\end{array}$ \\
\hline
\end{tabular}




\begin{tabular}{|c|c|c|c|c|c|c|c|c|c|}
\hline Name & Author & $\begin{array}{l}\text { Publication } \\
\text { Date }\end{array}$ & $\begin{array}{c}\text { Spatial } \\
\text { Coverage }\end{array}$ & $\begin{array}{c}\text { Spatial } \\
\text { Scale or } \\
\text { Resolution }\end{array}$ & $\begin{array}{l}\text { Temporal } \\
\text { Scale or } \\
\text { Resolution }\end{array}$ & $\begin{array}{l}\text { Methodology } \\
\text { Used }\end{array}$ & Units & Link & Abstract/Comments/Notes \\
\hline $\begin{array}{l}\text { Florida Biomass } \\
\text { Resources }\end{array}$ & $\begin{array}{l}\text { Florida } \\
\text { International } \\
\text { University }\end{array}$ & Jun-05 & Florida & $\begin{array}{l}\text { County. } \\
\text { Locations }\end{array}$ & Annual & GIS - ArclMS & & $\begin{array}{l}\text { hitto://hcetgis.hcet.fiu.edurwe } \\
\text { bsite/FL_Biomassidisclaimer } \\
\text { /about.htm }\end{array}$ & $\begin{array}{l}\text { Interactive map showing the biomass resources in } \\
\text { Florida. The goal is to provide open access to } \\
\text { information related to available biomass resources } \\
\text { in the state for potential energy production. It not } \\
\text { only maps these resources, but provides a means } \\
\text { by which their potential can be assessed by region } \\
\text { and available technologies. }\end{array}$ \\
\hline $\begin{array}{l}\text { Biomass Residue } \\
\text { Supply Curves for } \\
\text { the United States }\end{array}$ & $\begin{array}{c}\text { Antares Group } \\
\text { Inc. }\end{array}$ & Jun-99 & National & State & Annual & $\begin{array}{c}\text { Statistical } \\
\text { analysis }\end{array}$ & $d r y$ tons/yr & N/A & $\begin{array}{l}\text { The project estimated the availability of biomass } \\
\text { resources and built supply curves for each state. It } \\
\text { focused on woody biomass resources such as } \\
\text { forestry, mills, and urban residues. }\end{array}$ \\
\hline $\begin{array}{c}\text { Urban Wood } \\
\text { Waste Resource } \\
\text { Assessment }\end{array}$ & $\begin{array}{c}\text { Appel } \\
\text { Consultants, Inc. }\end{array}$ & Nov-98 & National & $\begin{array}{c}30 \\
\text { metropolitan } \\
\text { areas }\end{array}$ & Annual & $\begin{array}{c}\text { Statistical } \\
\text { analysis }\end{array}$ & tons/yr & hittp://wwww.p2pays.org/ref/19 & $\begin{array}{l}\text { This study collected and analyzed data on urban } \\
\text { wood waste resources in } 30 \text { randomly selected } \\
\text { metropolitan areas in the United States. The } \\
\text { metropolitan areas ranged in size from Bismarck. } \\
\text { North Dakota (83,831) to Washington, DC } \\
(3,923,574) \text {. } \\
\text { Three major categories of urban wood wastes were } \\
\text { considered in this study: MSW wood, industrial } \\
\text { wood, and Construction/Demolition debris. }\end{array}$ \\
\hline $\begin{array}{l}\text { Lignocellulosic } \\
\text { Feedstock } \\
\text { Resource } \\
\text { Assessment. }\end{array}$ & $\begin{array}{c}\text { NEOS } \\
\text { Corporation }\end{array}$ & Sep-98 & National & State & Annual & $\begin{array}{l}\text { Statistical } \\
\text { analysis }\end{array}$ & Dry tons & 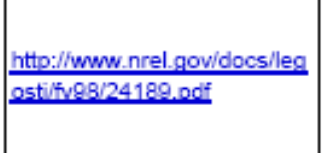 & $\begin{array}{l}\text { This study describes the distribution, quantity. } \\
\text { availability, competing uses, and current market } \\
\text { value of select lignocellulosic feedstock in the } \\
\text { United States. It provides feedstock data at a state } \\
\text { level. }\end{array}$ \\
\hline
\end{tabular}




\begin{tabular}{|c|c|c|c|c|c|c|c|c|c|}
\hline Name & Author & $\begin{array}{l}\text { Publication } \\
\text { Date }\end{array}$ & $\begin{array}{c}\text { Spatial } \\
\text { Coverage }\end{array}$ & $\begin{array}{c}\text { Spatial } \\
\text { Scale or } \\
\text { Resolution }\end{array}$ & $\begin{array}{l}\text { Temporal } \\
\text { Scale or } \\
\text { Resolution }\end{array}$ & $\begin{array}{l}\text { Methodology } \\
\text { Used }\end{array}$ & Units & Link & Abstract/Comments/Notes \\
\hline $\begin{array}{l}\text { Biomass Inventory } \\
\text { and Bioenergy } \\
\text { Assessment } \\
\text { An Evaluation of } \\
\text { Organic Material } \\
\text { Resources } \\
\text { for Bioenergy } \\
\text { Production in } \\
\text { Washington State }\end{array}$ & $\begin{array}{c}\text { Washington } \\
\text { State University } \\
\text { and Washington } \\
\text { State } \\
\text { Department of } \\
\text { Ecology }\end{array}$ & Dec-05 & $\begin{array}{l}\text { Washington } \\
\text { State }\end{array}$ & County & Annual & $\begin{array}{l}\text { Statistical } \\
\text { analysis }\end{array}$ & Dry tons & 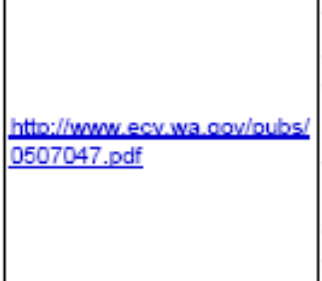 & $\begin{array}{l}\text { This project geographically identified, categorized, } \\
\text { and mapped } 45 \text { potential sources in Washington at } \\
\text { a county level. The categories included field } \\
\text { residues, animal manures, forestry residues, food } \\
\text { packing/processing waste, and municipal wastes. } \\
\text { The biomass inventory was then converted to } \\
\text { potential energy production using anaerobic } \\
\text { digestion and simple combustion as representative } \\
\text { conversion technologies. }\end{array}$ \\
\hline $\begin{array}{c}\text { Secondary Mill } \\
\text { Residues and } \\
\text { Urban Wood } \\
\text { Waste } \\
\text { Quantities in the } \\
\text { United States }\end{array}$ & $\begin{array}{l}\text { Jeffrey E. Fehrs, } \\
\text { P.E. } \\
\text { Williston, } \\
\text { Vermont }\end{array}$ & Dec-99 & National & National & Annual & $\begin{array}{l}\text { Statistical } \\
\text { analysis }\end{array}$ & Tons/year & 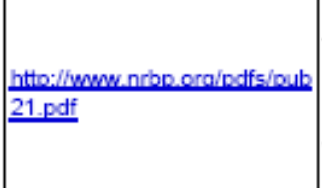 & $\begin{array}{l}\text { This study focuses on secondary mill residues and } \\
\text { urban wood wastes, and estimates quantities and } \\
\text { prices based on seven national wood waste } \\
\text { assessments completed by others. }\end{array}$ \\
\hline $\begin{array}{c}\text { Biomass Energy } \\
\text { Data Book }\end{array}$ & ORNL & Sep-06 & National & State & Annual & $\begin{array}{c}\text { Statistical } \\
\text { analysis }\end{array}$ & Acres/Dry Tons & $\begin{array}{l}\text { hitto:/lacta onl aov/badb/nodfi/ } \\
\text { iomass Energy Data Book. } \\
\text { odf }\end{array}$ & $\begin{array}{l}\text { The book represents an assembly and display of } \\
\text { statistics and information that characterize the } \\
\text { biomass industry, from the production of biomass } \\
\text { feedstocks to their end use. It inlcudes the following } \\
\text { feedstocks: grains and oilseed crops, some crop } \\
\text { residues (orchard trimmings and nut hulls), forest } \\
\text { residues, secondary mill residues and urban wood } \\
\text { waste (construction and demolition wood debris, } \\
\text { municipal solid wastes, and landill gases). }\end{array}$ \\
\hline $\begin{array}{l}\text { Assessing Ohio's } \\
\text { Biomass } \\
\text { Resources for } \\
\text { Energy Potential } \\
\text { Using GIS }\end{array}$ & $\begin{array}{l}\text { Ohio State } \\
\text { University }\end{array}$ & Oct-04 & Ohio & County & Annual & $\begin{array}{l}\text { Statistical } \\
\text { analysis and } \\
\text { GIS }\end{array}$ & Dry tons/yr & 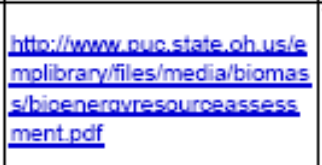 & $\begin{array}{l}\text { This study estimates crop and wood residues, } \\
\text { methane from livestock manure, and food } \\
\text { processing waste }\end{array}$ \\
\hline
\end{tabular}




\begin{tabular}{|c|c|c|c|c|c|c|c|c|c|}
\hline Name & Author & $\begin{array}{c}\text { Publication } \\
\text { Date }\end{array}$ & $\begin{array}{c}\text { Spatial } \\
\text { Coverage }\end{array}$ & $\begin{array}{c}\text { Spatial } \\
\text { Scale or } \\
\text { Resolution }\end{array}$ & $\begin{array}{l}\text { Temporal } \\
\text { Scale or } \\
\text { Resolution }\end{array}$ & $\begin{array}{c}\text { Methodology } \\
\text { Used }\end{array}$ & Units & Link & Abstract/Comments/Notes \\
\hline $\begin{array}{l}\text { The Economic } \\
\text { Feasibility of } \\
\text { Ethanol } \\
\text { Production from } \\
\text { Sugar in the } \\
\text { United States }\end{array}$ & USDA & Jul-06 & National & $\begin{array}{l}\text { National, } \\
\text { Regional, } \\
\text { and Select } \\
\text { State }\end{array}$ & Annual & $\begin{array}{c}\text { Statistical } \\
\text { analysis }\end{array}$ & $\begin{array}{l}\text { tons, S/ton, } \\
\text { \$/gallon }\end{array}$ & $\begin{array}{l}\text { htto://Wumw usda aovioce/Eth } \\
\text { anolSugarFeasibilityReport3 } \\
\text { odf }\end{array}$ & $\begin{array}{l}\text { This study investigates the economic feasibility of } \\
\text { producing ethanol from sugar feedstocks in the } \\
\text { United States. These sugar feedstocks include: } \\
\text { sugarcane juice, sugar beet juice, cane or beet } \\
\text { molasses, raw sugar, and refined sugar. Estimated } \\
\text { costs of producing ethanol from these feedstocks } \\
\text { are presented along with a discussion of other } \\
\text { factors that may influence the economic feasibility } \\
\text { of converting sugar feedstocks into ethanol. }\end{array}$ \\
\hline
\end{tabular}




\section{Viet Nam}

\section{Economy-Wide Biofuels Resource Assessments}

\section{First-Generation Biofuels Potential}

Ethanol: The existing ethyl alcohol industry in Viet Nam is already using starches (predominately rice) and sugar cane molasses as feedstock. Rice is the economy's main crop with production of more than $35 \mathrm{Mt}$ annually. Sugar cane production has been consistent during the past six years, about $15 \mathrm{Mt}$ annually. Another feedstock considered by the industry is cassava. The production has grown rapidly from 2 Mt in 2000 to about 8 million in 2006 .

If $20 \%$ of Viet Nam's current starch and sugar crops production could be used for biofuels, it would yield about $4.57 \mathrm{hm}^{3}$ of ethanol or $2.2 \mathrm{Mt}$ gasoline equivalent. This volume could replace $86 \%$ of Viet Nam's current gasoline consumption.

Biodiesel: Catfish oil and used cooking oil are the primary biodiesel feedstocks in Viet Nam. The Vietnamese Academy of Science and Technology (VAST) estimates that there were 60,000 tonnes of catfish oil produced in 2005, primarily for exports to the United States and Europe, and about 73,800 tonnes of used cooking oil. The economy produces oil crops such as coconut, peanuts, and soybeans mainly for domestic use by the food industry.

If $20 \%$ of Viet Nam's current coconut oil production, as well as all waste oils and fats, could be used for biofuels, it would yield about 164,000 tonnes of biodiesel. This volume would replace $4.6 \%$ of the economy's current diesel consumption.

\section{Second-Generation Biofuels Potential}

Ethanol: Viet Nam is very rich in lignocellulosic biomass. As illustrated in Table 31, the economy produced about $93 \mathrm{Mt}$ of crop and wood residues in 2002, which translates to about $28 \mathrm{hm}^{3}$ of ethanol or $13.4 \mathrm{Mt}$ of gasoline equivalent. This volume is more than enough in displacing the economy's current gasoline consumption. 
Table 31. Wood and Crop Residues Available in Viet Nam, 2002

\begin{tabular}{|l|r|r|}
\hline Wood residues \& fire wood & Million tonnes & Energy Content (TJ) \\
\hline Saw dust & 0.27 & 3,132 \\
\hline Wood chip & 1.33 & 19,950 \\
\hline Firewood & 12.4 & 186,000 \\
\hline Crop residues & & \\
\hline Paddy straw & 64.7 & 905,800 \\
\hline Rice husk & 6.81 & 77,634 \\
\hline Maize husk & 5.8 & 72,500 \\
\hline Cassava stem & 1.25 & 15,625 \\
\hline Cane trash & 1.68 & 21,000 \\
\hline Bagasse & 5.5 & 39,655 \\
\hline Peanut shells & 0,12 & 1,500 \\
\hline Coconut shells \& leaves & 5 & 90,000 \\
\hline Coffee husk & 0.28 & 4,359 \\
\hline Source: Nguyen Le Truong, Tran Quang Cu, 2004; TJ - Terajoule (10 &
\end{tabular}

Dedicated energy crops (particularly elephant grass) are also seen as an opportunity in Viet Nam. Pilot elephant grass plantations have been set up in Dongthap province (67 ha), BacKan (100 ha), and TuyenQuang (200 ha). Viet Nam is also exploring the opportunity to produce ethanol from seaweed.

Biodiesel: The Institute of Applied Materials \& Science and Institute of Tropical Biology in $\mathrm{HCMC}$ is researching the biodiesel production from rubber seed oil and other oil-bearing crops (jatropha). The Department of Agriculture \& Rural Development has a jatropha trial plantation of 5,000 ha. Eco-Carbone has identified four regions in Viet Nam for jatropha development, and will partner with local farmers and communities for a minimum of 30,000 ha.

\section{Regional and Local Biomass Resource Potential}

VAST estimated the main agricultural residues available in Viet Nam by region as illustrated in Table 32. No finer analysis of biomass resources (by province or municipality) was identified during this survey. 
Table 32. Main Agricultural Residues Available by Region in Viet Nam, 2006

\begin{tabular}{|l|c|c|c|c|}
\hline \multirow{2}{*}{ Areas of country } & \multicolumn{4}{|c|}{ Agriculture by production [million tons] } \\
\cline { 2 - 5 } & \multicolumn{2}{|c|}{ After processing } & After harvesting & $\begin{array}{c}\text { Total by } \\
\text { product }\end{array}$ \\
\cline { 2 - 5 } & $\begin{array}{c}\text { Rice } \\
\text { husk }\end{array}$ & Bagasse & Straw \& cane leaf & \\
\hline $\begin{array}{l}\text { The North mountain and } \\
\text { midland }\end{array}$ & 0.54 & 0.32 & 3.12 & 3.98 \\
\hline The Red river delta & 1.30 & 0.04 & 5.19 & 6.53 \\
\hline The North central & 0.58 & 0.76 & 2.79 & 4.13 \\
\hline The Central coast & 0.35 & 0.67 & 2.83 & 3.85 \\
\hline Central Highlands & 0.15 & 0.35 & 0.84 & 1.32 \\
\hline The South - East & 0.33 & 0.76 & 2.78 & 3.87 \\
\hline The Mekong river delta & 3.55 & 1.55 & 16.51 & 21.25 \\
\hline
\end{tabular}

Source: Tran Dinh Man, 2007

\section{Biomass Resource Assessment Capabilities}

Although no detailed biomass resource assessments were identified the time of this survey, it appears that Viet Nam has capabilities to improve the quality of existing analyses.

The Institute of Biotechnology and Institute of Environmental Technology at the Vietnamese Academy of Science and Technology (VAST) are the main agencies involved in biomass resource assessment. Several other entities provide expertise in agriculture and forestry such as the Faculty of Forestry, Nong Lam University (formerly University of Agriculture and Forestry), the Forest Science Institute of Vietnam (FSIV), Institute of Agricultural Technologies and Science, and Ministry of Agriculture and Rural Development (MARD).

Geospatial Technologies. The General Statistics Office (GSO) of Viet Nam and FAO jointly published an Agricultural Atlas of Vietnam in 2007. The atlas is the first product in Viet Nam to illustrate agricultural statistics in a spatial format. It used GIS to analyze and map a variety of 2001 Census variables related to agriculture and forestry in Viet Nam at commune level. The atlas's broad range of agricultural statistics is designed to provide a comprehensive overview of the geography of agricultural production in rural Viet Nam. Figure 36 illustrates an example of the series of maps presented in the atlas. 
GIS and RS have also been used by the Viet Nam Environment Protection Agency (VEPA) in its environmental-monitoring activities, and in the development of an atlas on Viet Nam's environment. The Ministry of Natural Resources and Environment (MONRE) maintains land use and land cover data.

Modeling. No information on modeling techniques used for agricultural and forestry analysis in Viet Nam was identified during this survey. However, the Information Center for Agriculture and Rural Development (AGROINFO) reported in 2007 that there is an agreement between the Economic Research Service-United States Department of Agriculture (ERS-USDA) and AGROINFO's Institute of Policy and Strategy for Agriculture and Rural Development (IPSARD) to exchange knowledge in modeling and other operating mechanisms for agricultural market analyses and forecasts, particularly for rice commodity.

Data Availability. The General Statistics Office (GSO) of Viet Nam is the main agency that collects and provides agricultural and forestry statistics. Data on crop-planted area, yield, production, and forest area and wood production is available by province. Information is provided annually (since 1995) in electronic format via the GSO Web site at http://www.gso.gov.vn. Detailed farm and agricultural and forestry enterprise data, at the level of the household, are only collected through censuses. Data is collected via sample paper and ground surveys. 
Figure 36. Forest Cover - Viet Nam

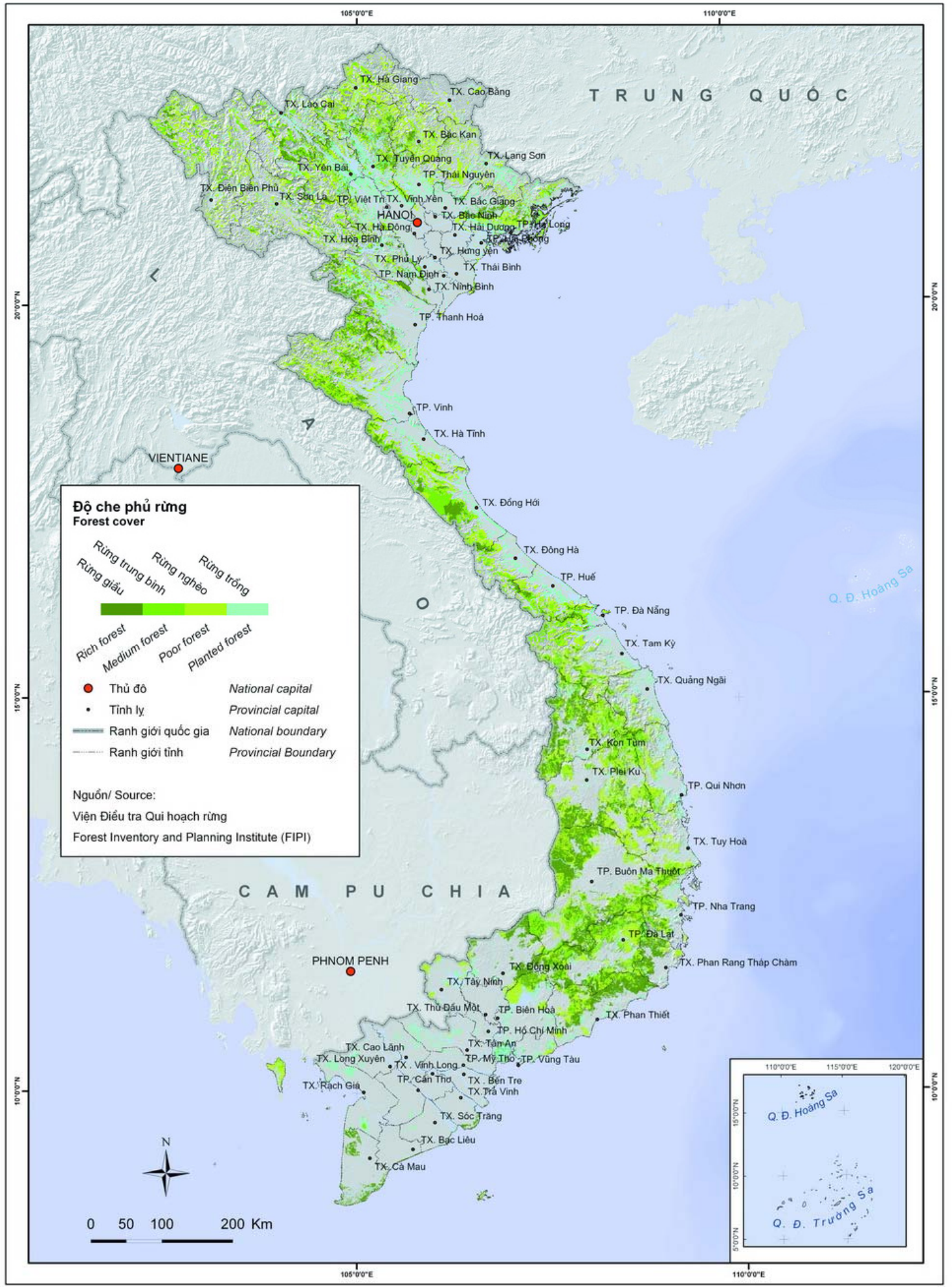

Source: GSO-FAO, 2007 


\section{References}

1. General Statistics Office (GSO) of Viet Nam and FAO, Agricultural Atlas of Viet Nam, 2007, http://www.agro.gov.vn/map3/content/default E.htm

2. Information Center for Agriculture and Rural Development (AGROINFO), Improving market analysis ability for IPSARD's rice experts, Accessed May 2008, http://www.agro.gov.vn/news/newsdetail.asp?targetlD=3598

3. Nguyen Hoai Chau, Institute of Environmental Technology, Vietnamese Academy of Science and Technology (VAST), Present Status on Biomass Energy Research and Development in Vietnam, 2002

4. Nguyen Le Truong, Energy Conservation R\&D Center, Tran Quang Cu, EC-ASEAN COGEN Programme, Potential of Distributed Power Generation from Biomass Residues in Vietnam - Status and Prospect, Electricity Supply Industry in Transition: Issues and Prospect for Asia, January 2004, http://www.cogen3.net/doc/countryinfo/vietnam/PotenstialDistributedPowerGenerationBi omassResidues.pdf

5. Regional Data Exchange System (RDES), FAO, Metadata for National Agricultural Statistics - Viet Nam, 2006, http://faorap-apcas.org/rdes/PPT/vietnam metadata.pdf

6. Tran Dinh Man, Institute of Biotechnology, Vietnamese Academy of Science and technology (VAST), Utilization of Agricultural and Wood Wastes in Vietnam, Presentation at the Biomass Asia Workshop, November 2007, http://biomass-asiaworkshop.jp/presentation files/34 Man.pdf

7. Tran Dinh Man, et al., Institute of Biotechnology, Vietnamese Academy of Science and technology (VAST), Research Activities on Bio Bio-Ethanol Production from Biomass in Vietnam, Presentation at the Asian Science and Technology Seminar (ASTS), Jakarta, Indonesia, 2007, http://www.jst.go.jp/asts/asts i/files/ppt/19 ppt.pdf 


\section{Conclusions}

Biomass Resource Assessments. This analysis revealed that most of the APEC economies have assessed their biomass resources at a broad, economy-wide level. Many have completed biomass resource assessments by state/province, and few at a finer geographic level county/district or local. Table 33 illustrates these findings.

Table 33. Biomass Resource Assessments in APEC Economies

\begin{tabular}{|c|c|c|c|c|}
\hline \multirow{2}{*}{ Economy } & \multicolumn{4}{|c|}{ Biomass Resource Assessments } \\
\hline & Economy-Wide & State/Province & County/District & Local \\
\hline Australia & $\mathrm{X}$ & $\mathrm{X}$ & $X$ & $\mathrm{X}$ \\
\hline Brunei Darussalam & $\sim$ & $\sim$ & $\sim$ & $\sim$ \\
\hline Canada & $\mathrm{X}$ & $\mathrm{X}$ & $\mathrm{O}$ & $\mathrm{O}$ \\
\hline Chile & $\mathrm{X}$ & $\mathrm{X}$ & $\mathrm{X}$ & $\mathrm{X}$ \\
\hline China & $\mathrm{X}$ & $\mathrm{X}$ & $\mathrm{O}$ & $\mathrm{O}$ \\
\hline Hong Kong, China & $X$ & $\sim$ & $\sim$ & $\sim$ \\
\hline Indonesia & $\mathrm{X}$ & $X$ & $X$ & $\mathrm{X}$ \\
\hline Japan & $\mathrm{X}$ & N/A & N/A & N/A \\
\hline Korea & $\mathrm{X}$ & $X$ & $\mathrm{X}$ & $\mathrm{N} / \mathrm{A}$ \\
\hline Malaysia & $X$ & N/A & N/A & N/A \\
\hline Mexico & $X$ & $X$ & $\mathrm{X}$ & $X$ \\
\hline New Zealand & $X$ & $X$ & N/A & N/A \\
\hline Papua New Guinea & $X$ & N/A & $\mathrm{N} / \mathrm{A}$ & $\mathrm{N} / \mathrm{A}$ \\
\hline Peru & $\mathrm{X}$ (biodiesel only) & N/A & N/A & N/A \\
\hline The Philippines & $X$ & $X$ & $X$ & N/A \\
\hline Russia & N/A & N/A & N/A & N/A \\
\hline Singapore & X (urban wood only) & $\sim$ & $\sim$ & $\sim$ \\
\hline Chinese Taipei & $X$ & N/A & $\mathrm{N} / \mathrm{A}$ & N/A \\
\hline Thailand & $X$ & $X$ & $X$ & $X$ \\
\hline United States & $X$ & $\mathrm{X}$ & $\mathrm{X}$ & $X$ \\
\hline Viet Nam & $X$ & N/A & N/A & N/A \\
\hline
\end{tabular}

N/A - Information not available; " " Not applicable; "O" - Under development

Biomass Resource Assessment Capabilities. The survey found that all economies have the necessary capabilities to conduct biomass resource assessments - scientific knowledge, tools, and data. However, not all of them have used their full capabilities in existing products. Some members have used their advanced capabilities, such as RS/GIS and simulation modeling, to develop detailed analyses of resource potential. For others, the survey identified products that are not direct examples of biomass resource assessments, but they indicate existing capabilities that could be applied to future resource assessment projects, enabling economies to achieve fine geographic presentation of resources and project potential. Table 34 illustrates these findings. 
Table 34. Biomass Resource Assessment Capabilities in APEC Economies

\begin{tabular}{|c|c|c|c|c|}
\hline \multirow{3}{*}{ Economy } & \multicolumn{4}{|c|}{ Biomass Resource Assessment Capabilities } \\
\hline & \multirow[t]{2}{*}{ Remote Sensing/GIS } & \multicolumn{2}{|c|}{ Modeling } & \multirow[t]{2}{*}{ Field/Paper Survey } \\
\hline & & Static/Numeric* & Dynamic/Simulation & \\
\hline Australia & $\mathrm{X}$ & $\mathrm{X}$ & $\mathrm{X}$ & $\mathrm{X}$ \\
\hline \begin{tabular}{|l|} 
Brunei Darussalam \\
\end{tabular} & $\mathrm{X}$ & $\mathrm{X}$ & $\mathrm{N} / \mathrm{A}$ & $\mathrm{X}$ \\
\hline Canada & $\mathrm{x}$ & $\mathrm{X}$ & $\mathrm{X}$ & $\mathrm{X}$ \\
\hline Chile & $\mathrm{X}$ & $\bar{X}$ & $\mathrm{~N} / \mathrm{A}$ & $\mathrm{X}$ \\
\hline China & $\mathrm{X}$ & $\mathrm{X}$ & $\mathrm{N} / \mathrm{A}$ & $\mathrm{X}$ \\
\hline Hong Kong, China & $\mathrm{X}$ & $\bar{x}$ & $\mathrm{~N} / \mathrm{A}$ & $\bar{x}$ \\
\hline Indonesia & $\mathrm{X}$ & $\mathrm{X}$ & $\mathrm{N} / \mathrm{A}$ & $\mathrm{X}$ \\
\hline Japan & $\mathrm{X}$ & $\mathrm{X}$ & $\mathrm{X}$ & $\mathrm{X}$ \\
\hline Korea & $\mathrm{X}$ & $\bar{X}$ & $\mathrm{~N} / \mathrm{A}$ & $\mathrm{X}$ \\
\hline \begin{tabular}{|l|} 
Malaysia \\
\end{tabular} & $\mathrm{X}$ & $\mathrm{X}$ & $\mathrm{N} / \mathrm{A}$ & $\mathrm{X}$ \\
\hline Mexico & $\mathrm{X}$ & $\mathrm{X}$ & $\mathrm{X}$ & $\mathrm{X}$ \\
\hline New Zealand & $\mathrm{X}$ & $\mathrm{X}$ & $\mathrm{N} / \mathrm{A}$ & $\mathrm{X}$ \\
\hline Papua New Guinea & $\mathrm{X}$ & $\mathrm{X}$ & $\mathrm{N} / \mathrm{A}$ & $\mathrm{X}$ \\
\hline Peru & $\mathrm{X}$ & $\mathrm{X}$ & $\mathrm{N} / \mathrm{A}$ & $\mathrm{X}$ \\
\hline The Philippines & $\mathrm{X}$ & $\mathrm{X}$ & $\mathrm{N} / \mathrm{A}$ & $\mathrm{X}$ \\
\hline Russia & $X$ & $\mathrm{X}$ & $\mathrm{X}$ & $\mathrm{X}$ \\
\hline Singapore & $\mathrm{X}$ & $\mathrm{X}$ & $\mathrm{N} / \mathrm{A}$ & $\mathrm{X}$ \\
\hline Chinese Taipei & $\mathrm{X}$ & $\mathrm{X}$ & $\mathrm{N} / \mathrm{A}$ & $\mathrm{X}$ \\
\hline Thailand & $\mathrm{X}$ & $\mathrm{X}$ & $\mathrm{N} / \mathrm{A}$ & $X$ \\
\hline United States & $\mathrm{X}$ & $\mathrm{X}$ & $\mathrm{X}$ & $\mathrm{X}$ \\
\hline Viet Nam & $\mathrm{X}$ & $\mathrm{X}$ & $\mathrm{O}$ & $\mathrm{X}$ \\
\hline
\end{tabular}

* In most cases, applying product to residue ratio; ** Used mostly for collecting agricultural and forestry statistics

N/A - Information not available; " " - Not applicable; "O" - Under development

The overall survey findings are presented below.

Economies with Good Resource Assessment Capabilities and Detailed Resource Assessments: Australia, Canada, Chile, Indonesia, Korea, Mexico, the Philippines, Thailand, United States

Economies with Good Resource Assessment Capabilities and Medium Scale (state/province) Resource Assessments: China, New Zealand

Economies with Good Resource Assessment Capabilities and Broad (Economy-Wide) Resource Assessments: Japan, Malaysia, Chinese Taipei, Viet Nam

Economies with Good Resource Assessment Capabilities and Limited or No Resource Assessments: Papua New Guinea, Peru, Russia

Economies with Limited Biofuel Resources: Brunei Darussalam, Hong Kong, Singapore

Resource Availability for Ethanol and Potential Gasoline Displacement. Considering the controversy surrounding the use of conventional crops for biofuels production, this project paid particular attention to assessments of alternative (non-food) biomass resources, such as crop and forest residues. The resource availability in the APEC region is estimated at about 1,700 Mt, which would yield $509 \mathrm{hm}^{3}$ of ethanol or $245 \mathrm{Mt}$ gasoline equivalent. This volume would 
replace $40 \%$ of the region's current gasoline consumption and just below $20 \%$ of crude oil import. Many economies could substitute a substantial volume of their current gasoline consumption with ethanol from second generation feedstock, while others such as China, Thailand, and Viet Nam could substitute their entire consumption (Table 36). A note should be made, however, that this estimate doesn't account for current uses of these resources by other industries such as power/heat generation and bioproducts (plastics, chemicals, etc.). Therefore, more detailed analyses are needed to evaluate the resources that are actually available for biofuels production.

With respect to first generation feedstock, the study evaluated the contribution of $20 \%$ of the economies' current starch and sugar crops production. This number is somewhat arbitrary and simply a choice made here. It is reasonable to assume for net importing economies, such as Chile, Japan, Korea, and Chinese Taipei that biofuels production from these crops will not be viable in the near future. However, with advancements in crop development and yield increase, the situation in these economies may change with time. The first generation resource availability in the APEC region is estimated at $252 \mathrm{Mt}$, equal to about $92 \mathrm{hm}^{3}$ of ethanol (44 Mt gasoline equivalent), enough to replace only $7 \%$ of APEC's current gasoline consumption and $3.5 \%$ of crude oil import (Table 35).

Resource Availability for Biodiesel and Potential Petro-Diesel Displacement. The assessment of biodiesel resource availability was conducted in a similar way to the ethanol assessment. However, data on second generation feedstock (non-edible crops, such as Jatropha and Pongam, or from algae) was insufficient to provide meaningful results. If $20 \%$ of economies' current vegetable oil production, as well as all waste oils and fats, are used for biofuels, it would yield about $21.8 \mathrm{Mt}$ of biodiesel. This amount would replace $6.8 \%$ of their current diesel consumption and $1.7 \%$ of crude oil import (Table 37 ). Economies with the highest resource availability include China, Indonesia, Malaysia, and the United States. It is expected that the resource potential for biodiesel production in APEC economies will increase significantly over the next years with the development of second generation feedstock. 
Table 35. First-generation Resource Availability for Ethanol Production in APEC Economies

\begin{tabular}{|c|c|c|c|c|c|c|c|c|}
\hline Economy & Feedstock Type & $\begin{array}{c}20 \% \text { of } \\
\text { Current } \\
\text { Production } \\
(\text { '000 tonnes })^{*}\end{array}$ & $\begin{array}{l}\text { Ethanol } \\
\text { Potential } \\
\text { (hm3) }\end{array}$ & $\begin{array}{c}\text { Gasoline } \\
\text { Equivalent } \\
\text { ('000 tonnes) }\end{array}$ & $\begin{array}{c}\text { Gasoline } \\
\text { Consumption } \\
(\text { '000 tonnes)** }\end{array}$ & $\begin{array}{c}\text { Share of } \\
\text { Gasoline } \\
\text { Consumption } \\
(\%)\end{array}$ & $\begin{array}{c}\text { Crude oil } \\
\text { Import } \\
\text { ('000 tonnes })^{* *}\end{array}$ & $\begin{array}{l}\text { Share of } \\
\text { Crude Oil } \\
\text { Import } \\
(\%)\end{array}$ \\
\hline Australia & $\begin{array}{l}\text { barley, corn, oats, rice, } \\
\text { sorghum, sugar cane, } \\
\text { wheat }\end{array}$ & 8,919 & 3.11 & 1,498 & 14,520 & 10.3 & 20,070 & 7.5 \\
\hline Brunei & & & & & 196 & & & \\
\hline Canada & $\begin{array}{l}\text { barley, corn, oats, } \\
\text { sugar beet, wheat }\end{array}$ & 6,765 & 2.18 & 1,050 & 29,751 & 3.5 & 45,336 & 2.3 \\
\hline Chile & corn, sugar beet, wheat & 635 & 0.26 & 125 & 2,081 & 6.0 & 10,219 & 1.2 \\
\hline China & $\begin{array}{l}\text { cassava, corn, rice, } \\
\text { sorghum, sugar cane, } \\
\text { sweet potato, wheat }\end{array}$ & 96,590 & 32 & 15,416 & 46,097 & 33.4 & 126,817 & 12.2 \\
\hline Hong Kong & & & & & 325 & & 352 & \\
\hline Indonesia & cassava, rice, sugar & 16,400 & 6.73 & 3,242 & 12,942 & 25.1 & 20,829 & 15.6 \\
\hline Japan & $\begin{array}{l}\text { rice, sugar beet, sugar } \\
\text { cane, wheat }\end{array}$ & 2,000 & 0.75 & 361 & 44,391 & 0.8 & 207,266 & 0.2 \\
\hline Korea & rice & 954 & 0.33 & 159 & 6,969 & 2.3 & 113,234 & 0.1 \\
\hline Malaysia & rice & 288 & 0.10 & 48 & 7,756 & 1 & 7,885 & 0.6 \\
\hline Mexico & $\begin{array}{l}\text { corn, sorghum, sugar } \\
\text { cane, wheat }\end{array}$ & 6,830 & 3.02 & 1,455 & 27,704 & 5.3 & & \\
\hline New Zealand & whey & $\mathrm{N} / \mathrm{A}$ & 0.015 & 7 & 2,325 & 0.3 & 4,488 & 0.2 \\
\hline PNG & sugar cane & 100 & 0.06 & 29 & $\mathrm{~N} / \mathrm{A}$ & $\mathrm{N} / \mathrm{A}$ & 435 & 6.6 \\
\hline Peru & $\begin{array}{l}\text { cassava, corn, rice, } \\
\text { sugar cane, sweet } \\
\text { potato }\end{array}$ & 2,039 & 0.99 & 477 & 771 & 61.9 & 4,809 & 9.9 \\
\hline The Philippines & cassava, sugar cane & 804 & 0.33 & 159 & 4,111 & 3.9 & 10,681 & 1.5 \\
\hline Russia & $\begin{array}{l}\text { barley, corn, oats, rice, } \\
\text { sugar beet, wheat }\end{array}$ & 14,774 & 4.87 & 2,346 & 26,260 & 8.9 & & \\
\hline Singapore & & & & & 727 & & 54,786 & \\
\hline Chinese Taipei & rice, sweet potato & 247 & 0.08 & 39 & 7,845 & 0.5 & 54,035 & 0.1 \\
\hline Thailand & $\begin{array}{l}\text { Cassava, rice, sweet } \\
\text { potato }\end{array}$ & 8,677 & 2.70 & 1,301 & 5,280 & 24.6 & 39,815 & 3.3 \\
\hline United States & $\begin{array}{l}\text { barley, corn, oats, rice, } \\
\text { sorghum, sugar beet, } \\
\text { sugar cane, wheat }\end{array}$ & 74,000 & 30 & 14,452 & 373,930 & 3.9 & 538,651 & 2.7 \\
\hline Viet Nam & $\begin{array}{l}\text { Cassava, rice, sugar } \\
\text { cane }\end{array}$ & 11,600 & 4.57 & 2,202 & 2,546 & 86.5 & & \\
\hline APEC Total & & 251,622 & 92.1 & 44,365 & 616,527 & 7.2 & $1,259,708$ & 3.5 \\
\hline
\end{tabular}

*Source: USDA (indexmundi.com), 2005; ** Source: IEA, 2005; $\mathrm{hm}^{3}$ - cubic hectometer or 1,000,000 $\mathrm{m}^{3}$ or $10^{9} \mathrm{~L}$, described in some sources as a GL (Gigaliter);

$\mathrm{N} / \mathrm{A}$ - information not available; Areas in gray - not applicable; to compute 1,000 tonne gasoline equivalent: ethanol volume (hm3)*21.1PJ/43.8 TJ. 
Table 36. Second-generation Resource Availability for Ethanol Production in APEC Economies

\begin{tabular}{|c|c|c|c|c|c|c|c|c|}
\hline Economy & Feedstock Type & $\begin{array}{c}\text { Resource } \\
\text { Availability } \\
\text { ('000 tonnes) }\end{array}$ & $\begin{array}{l}\text { Ethanol } \\
\text { Potential } \\
\text { (hm3) }\end{array}$ & $\begin{array}{c}\text { Gasoline } \\
\text { Equivalent } \\
\text { ('000 tonnes) }\end{array}$ & $\begin{array}{c}\text { Gasoline } \\
\text { Consumption } \\
\text { ('000 tonnes)* }\end{array}$ & $\begin{array}{c}\text { Share of } \\
\text { Gasoline } \\
\text { Consumption } \\
(\%)\end{array}$ & $\begin{array}{l}\text { Crude Oil Import } \\
\text { ('000 tonnes)* }\end{array}$ & $\begin{array}{c}\text { Share of } \\
\text { Crude oil } \\
\text { Import } \\
(\%)\end{array}$ \\
\hline Australia & $\begin{array}{l}\text { crop, forest, and primary } \\
\text { mill residues; urban wood } \\
\text { waste }\end{array}$ & 36,700 & 11.0 & 5,299 & 14,520 & 36.5 & 20,070 & 26.4 \\
\hline Brunei & & & & & 196 & & & \\
\hline Canada & $\begin{array}{l}\text { crop, forest, and primary } \\
\text { mill residues; hog fuel piles }\end{array}$ & 71,000 & 21.3 & 10,261 & 29,751 & 34.5 & 45,336 & 22.6 \\
\hline Chile & primary mill residues & 3,254 & 0.9 & 434 & 2,081 & 20.8 & 10,219 & 4.2 \\
\hline China & $\begin{array}{l}\text { crop, forest, and primary } \\
\text { mill residues }\end{array}$ & 788,000 & 236.0 & 113,689 & 46,097 & 246.6 & 126,817 & 89.6 \\
\hline Hong Kong & & & & & 325 & & 352 & \\
\hline Indonesia & $\begin{array}{l}\text { crop residues; sugar cane } \\
\text { bagasse; oil-palm, rubber, } \\
\text { and coconut residues }\end{array}$ & 74,000 & 22.2 & 10,695 & 12,942 & 82.6 & 20,829 & 51.3 \\
\hline Japan & $\begin{array}{l}\text { crop and forest residues; } \\
\text { urban wood waste }\end{array}$ & 15,000 & 4.5 & 2,168 & 44,391 & 4.9 & 207,266 & 1.0 \\
\hline Korea & crop and forest residues & 13,100 & 3.9 & 1,879 & 6,969 & 27.0 & 113,234 & 1.7 \\
\hline Malaysia & $\begin{array}{l}\text { crop residues; sugar cane } \\
\text { bagasse; oil-palm and wood- } \\
\text { processing residues }\end{array}$ & 32,392 & 9.7 & 4,673 & 7,756 & 60.2 & 7,885 & 59.3 \\
\hline Mexico & $\begin{array}{l}\text { crop, logging, and primary } \\
\text { mill residues }\end{array}$ & 74,500 & 22.4 & 10,767 & 27,704 & 38.9 & & \\
\hline New Zealand & $\begin{array}{l}\text { crop, logging, and primary } \\
\text { mill residues; horticultural } \\
\text { and urban wood waste }\end{array}$ & 5,500 & 1.7 & 795 & 2,325 & 34.2 & 4,488 & 17.7 \\
\hline PNG & $\begin{array}{l}\text { logging, oil-palm, and } \\
\text { coconut residues; sugar } \\
\text { cane bagasse }\end{array}$ & $\mathrm{N} / \mathrm{A}$ & $\mathrm{N} / \mathrm{A}$ & $\mathrm{N} / \mathrm{A}$ & $\mathrm{N} / \mathrm{A}$ & $\mathrm{N} / \mathrm{A}$ & 435 & $\mathrm{~N} / \mathrm{A}$ \\
\hline Peru & $\begin{array}{l}\text { crop, logging, and oil-palm } \\
\text { residues; sugar cane } \\
\text { bagasse }\end{array}$ & $\mathrm{N} / \mathrm{A}$ & $\mathrm{N} / \mathrm{A}$ & $\mathrm{N} / \mathrm{A}$ & 771 & $\mathrm{~N} / \mathrm{A}$ & 4,809 & $\mathrm{~N} / \mathrm{A}$ \\
\hline The Philippines & $\begin{array}{l}\text { crop, logging, and coconut } \\
\text { residues; sugar cane } \\
\text { bagasse }\end{array}$ & 18,000 & 5.4 & 2,601 & 4,111 & 63.3 & 10,681 & 24.4 \\
\hline Russia & crop and forest residues & 100,000 & 30.0 & 14,452 & 26,260 & 55.0 & & \\
\hline Singapore & & & & & 727 & & 54,786 & \\
\hline Chinese Taipei & crop residues & 1,900 & 0.6 & 275 & 7,845 & 3.5 & 54,035 & 0.5 \\
\hline Thailand & $\begin{array}{l}\text { crop residues; sugar cane } \\
\text { bagasse; oil-palm and } \\
\text { coconut residues }\end{array}$ & 47,800 & 14.3 & 6,889 & 5,280 & 130.5 & 39,815 & 17.3 \\
\hline United States & $\begin{array}{l}\text { crop, forest, primary mill, } \\
\text { and secondary mill residues; } \\
\text { urban wood waste }\end{array}$ & 324,448 & 97.3 & 46,873 & 373,930 & 12.5 & 538,651 & 8.7 \\
\hline Viet Nam & $\begin{array}{l}\text { crop, wood-processing, and } \\
\text { coconut residues; sugar } \\
\text { cane bagasse }\end{array}$ & 93,000 & 27.9 & 13,440 & 2,546 & 527.9 & & \\
\hline APEC Total & & $1,698,594$ & 509.0 & 245,189 & 616,527 & 39.8 & $1,259,708$ & 19.5 \\
\hline
\end{tabular}

*Source: IEA, 2005; $\mathrm{hm}^{3}$ - cubic hectometer or $1,000,000 \mathrm{~m}^{3}$ or $10^{9} \mathrm{~L}$, described in some sources as a GL (Gigaliter); N/A - information not available,

Areas in gray - not applicable; to compute 1,000 tonne gasoline equivalent: ethanol volume $(\mathrm{hm} 3)^{\star} 21.1 \mathrm{PJ} / 43.8 \mathrm{TJ}$. 
Table 37. Resource Availability for Biodiesel Production in APEC Economies

\begin{tabular}{|c|c|c|c|c|c|c|c|c|}
\hline Economy & Vegetable Oils & $\begin{array}{c}20 \% \text { of } \\
\text { Current } \\
\text { Production } \\
(\text { '000 tonnes)* }\end{array}$ & $\begin{array}{c}\text { Waste Oils } \\
\text { and Fats } \\
\text { ('000 tonnes) }\end{array}$ & $\begin{array}{c}\text { Biodiesel } \\
\text { Potential } \\
\text { ('000 tonnes) }\end{array}$ & $\begin{array}{c}\text { Diesel } \\
\text { Consumption } \\
(\text { '000 tonnes })^{* *}\end{array}$ & $\begin{array}{c}\text { Share of } \\
\text { Diesel } \\
\text { Consumption } \\
(\%)\end{array}$ & $\begin{array}{l}\text { Crude oil Import } \\
\text { ('000 tonnes)** }\end{array}$ & $\begin{array}{c}\text { Share of } \\
\text { Crude oil } \\
\text { Import } \\
(\%)\end{array}$ \\
\hline Australia & rapeseed, soybean & 39 & 340 & 379 & 7,643 & 5.0 & 20,070 & 1.9 \\
\hline Brunei & & & & & 107 & & & \\
\hline Canada & rapeseed, soybean & 339 & 211 & 550 & 12,511 & 4.4 & 45,336 & 1.2 \\
\hline Chile & rapeseed, soybean & 8 & 46 & 54 & 3,260 & 1.7 & 10,219 & 0.5 \\
\hline China & rapeseed, soybean, & 2,226 & 3,000 & 5,226 & 46,934 & 11.1 & 126,817 & 4.1 \\
\hline Hong Kong & & & 9 & 9 & 1,317 & 0.7 & 3,512 & 0.3 \\
\hline Indonesia & palm, coconut & 3,376 & $\mathrm{~N} / \mathrm{A}$ & 3,376 & 9,974 & 33.8 & 20,829 & 16.2 \\
\hline Japan & rapeseed, soybean & 285 & 500 & 785 & 27,896 & 2.8 & 207,266 & 0.4 \\
\hline Korea & soybean & 31 & 230 & 261 & 14,841 & 1.8 & 113,234 & 0.2 \\
\hline Malaysia & palm & 3,200 & $\mathrm{~N} / \mathrm{A}$ & 3,200 & 4,998 & 64.0 & 7,885 & 40.6 \\
\hline Mexico & rapeseed, soybean & 230 & $\mathrm{~N} / \mathrm{A}$ & 230 & 12,487 & 1.8 & & \\
\hline New Zealand & & & 132 & 132 & 1,741 & 7.6 & 4,488 & 2.9 \\
\hline PNG & palm, coconut & 82 & $\mathrm{~N} / \mathrm{A}$ & 82 & 170 & 48.2 & 435 & 18.9 \\
\hline Peru & palm & 9 & 294 & 303 & 2,209 & 13.7 & 4,809 & 6.3 \\
\hline The Philippines & coconut & 310 & $\mathrm{~N} / \mathrm{A}$ & 310 & 4,211 & 7,4 & 10,681 & 2.9 \\
\hline Russia & rapeseed, soybean, & 506 & $\mathrm{~N} / \mathrm{A}$ & 506 & 13,527 & 3.7 & & \\
\hline Singapore & & & & & 1,323 & & 54,786 & \\
\hline Chinese Taipei & soybean & 77 & 189 & 266 & 3,657 & 7.3 & 54,035 & 0.5 \\
\hline Thailand & palm, coconut, soybean & 217 & $\mathrm{~N} / \mathrm{A}$ & 217 & 12,625 & 1.7 & 39,815 & 0.5 \\
\hline United States & rapeseed, soybean, & 1,975 & 3,741 & 5,716 & 135,346 & 4.2 & 538,651 & 1.1 \\
\hline Viet Nam & coconut & 30 & 134 & 164 & 3,558 & 4.6 & & \\
\hline APEC Total & & 12,940 & 8,826 & 21,766 & 320,335 & 6.8 & $1,262,868$ & 1.7 \\
\hline
\end{tabular}


Prepared By:

Anelia Milbrandt

National Renewable Energy Laboratory (NREL)

1617 Cole Blvd

Golden, Colorado, USA 80401

Phone: (303) 275-3000

Website: www.nrel.gov

Dr. Ralph P. Overend

NREL Research Fellow (Retired)

Ottawa, Ontario, Canada

Produced for:

APEC Secretariat

35 Heng Mui Keng Terrace Singapore 119616

Tel: (65) 68919-600 Fax: (65) 68919-690

Email: info@apec.org Website: www.apec.org

(c) 2008 APEC Secretariat

APEC\# 208-RE-01.9 